UNIVERSIDADE DE SÃO PAULO

FACULDADE DE FILOSOFIA, LETRAS E CIÊNCIAS HUMANAS

DEPARTAMENTO DE LETRAS CLÁSSICAS E VERNÁCULAS

PROGRAMA DE PÓS-GRADUAÇÃO EM LITERATURA BRASILEIRA

\title{
As Ilusões do Romance: Estrutura e Percepção em São Bernardo de Graciliano Ramos
}

Edilson Dias de Moura

Dissertação apresentada ao Programa de Pós-Graduação em Literatura Brasileira do Departamento de Letras Clássicas e Vernáculas da Faculdade de Filosofia, Letras e Ciências Humanas da Universidade de São Paulo, para a obtenção do Título de Mestre em Letras.

Orientador: Prof. Dr. João Adolfo Hansen
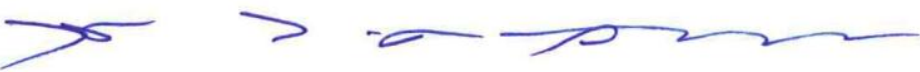

v. 1 (versão revisada)

São Paulo 
A minha bisavó Prudência, minhas avós Aurora e Rosa, meus pais e irmãos.

\section{AGRADECIMENTOS}

Naturalmente agradeço ao meu orientador João Adolfo Hansen o incentivo a pesquisar o tema, que teve origem em 2003 no curso de Literatura Brasileira II, por ele ministrado na Faculdade de Letras na USP. À minha esposa Maria Elaine Andreoti, ouvinte paciente das minhas digressões e que permitiu o tão longo convívio das figuras de Graciliano Ramos em nossa casa durante esses tempos de pesquisa. Aos professores Hélio de Seixa Guimarães, Valentim A. Facioli, Luiz Costa Lima, Hélder Garmes, Claudia Amigo Pino, Cilaine Alves Cunha e ao desconhecido parecerista da Fapesp.

Aos amigos Thiago Mio Salla, Lica Hashimoto, Phabulo Mendes, Mário Tommaso Pugliese, Mônica Gama, Laura Penna Alves, Giuliano Lellis Ito Santos e Daiane Cristiana Pereira, Elói, Cláudio Eduardo Andreoti e à professora Elizabeth Franco. Aos funcionários da Fundação Casa de Rui Barbosa: Leonardo, Cláudio e Aline, os quais prestativamente me ofereceram toda a assistência necessária às minhas consultas, estando a mesma temporariamente fechada para recatalogação e atualização de seu acervo.

Agradeço ainda o apoio da bolsa de pesquisa concedida pela Fapesp. 
Assim, qualquer estudo literário, por mais profundo que seja - e não importa o quão sutil e preciso o instrumental utilizado -, alcançará apenas a superfície da obra. Esta é insondável e as tentativas de a revelar, ampliando-a, multiplica igualmente os seus mistério. Compreender melhor uma obra não significa decifrá-la: os seus corredores são infindos.

Osman Lins 


\section{SUMÁRIO}

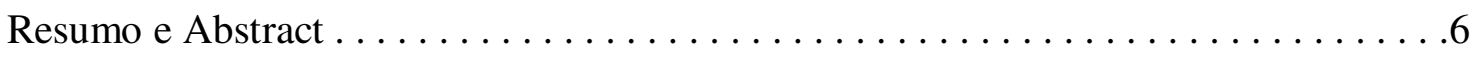

Apresentação geral . . . . . . . . . . . . . . . . . . . . .

Primeira parte

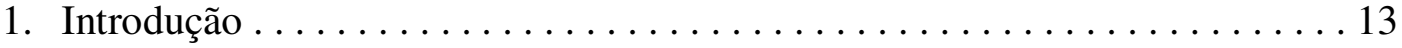

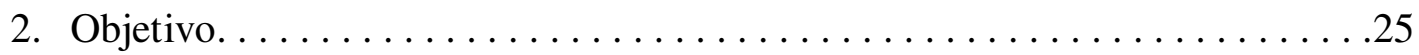

3. Recorte teórico e metodologia . . . . . . . . . . . . . . . . . . 29

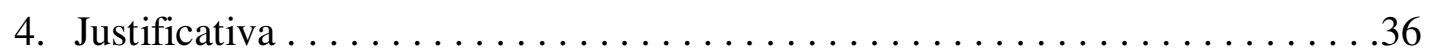

Segunda Parte

1. Estrutura e percepção: a ficção do leitor . . . . . . . . . . . . . . . 54

2. A escrita utópica de Paulo Honório . . . . . . . . . . . . . . . . 62

3. O enigma da coruja ou o canto da sereia . . . . . . . . . . . . . . 74

4. A recepção crítica de São Bernardo pós-anos $50 \ldots \ldots \ldots \ldots \ldots \ldots$. . . . . . . .

5. Entre achados e perdidos, ao menos fragmentos de capítulos. . . . . . . . .95

Terceira Parte

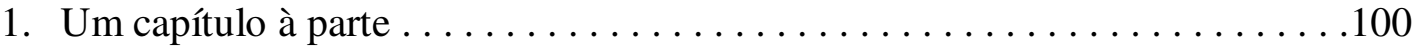

2. Memória fragmentada . . . . . . . . . . . . . . . . . . . . . . . . 104

3. A volta do filho às avessas . . . . . . . . . . . . . . . . . . 116

4. As ilusões do romance. . . . . . . . . . . . . . . . . . . . . 126

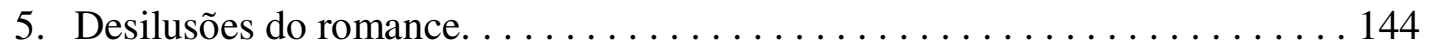

6. Declínio: nascimento e morte. . . . . . . . . . . . . . . . . . . . . 160

Quarta Parte

1. A antecedência do processo . . . . . . . . . . . . . . . . . . . 172

2. A teoria do romance em São Bernardo . . . . . . . . . . . . . . . . . . . 177 
3. Fronteiras e limites de São Bernardo. . . . . . . . . . . . . . . . . . 190

4. O manifesto da prática . . . . . . . . . . . . . . . . . . . 203

5. Critérios de transcrição dos textos e contextualização. . . . . . . . . . . . 212

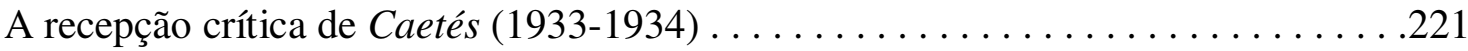

A recepção crítica de São Bernardo $(1934-1935) \ldots \ldots \ldots \ldots \ldots \ldots \ldots \ldots \ldots . \ldots \ldots$

Recorte temporal final: vários assuntos $(1936-1938) \ldots \ldots \ldots \ldots \ldots \ldots \ldots$. . . . . . 257

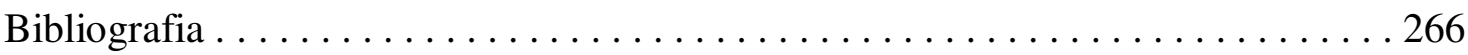

Bibliografia crítica sobre São Bernardo . . . . . . . . . . . . . . . . . . . . . . 267

Bibliografia crítica sobre o autor e outras obras. . . . . . . . . . . . . . 268

Bibliografia geral. . . . . . . . . . . . . . . . . . . . . . . . . . . . . . . .269 


\section{Resumo:}

As Ilusões do Romance: Estrutura e Percepção em São Bernardo de Graciliano Ramos é um estudo e análise da narrativa, dos efeitos do ato de leitura (ISER; 1996) produzido pelo romance, que se finaliza com uma compreensão histórica da obra, segundo sua recepção crítica surgida na década de 1930. A fim de dar conta deste último item de pesquisa, lançou-se mão das noções teóricas da estética da recepção (JAUSS: 1994). A partir do estudo, portanto, da estrutura do romance (segundo a teoria e análise do discurso), dos efeitos produzidos no ato da leitura e da recepção histórica dos textos, defende-se a tese de que São Bernardo é uma obra em que seus personagens funcionam como máscara de ideais literários, o que permite ao autor criticar os supostos efeitos causados pela ilusão do texto ficcional. Fato que faz com que São Bernardo deva sua modernidade exatamente à pluralidade discursiva, à indução da expectativa de valores literários, chegando quase a parecer-nos polifônico no sentido que Bakhtin estuda e propõe que seja a obra de Dostoiévski. Daí seu narrador, Paulo Honório, ainda hoje ser visto como um narrador pouco comum, atraindo as atenções da crítica e a deixando na situação embaraçosa da contradição, exigindo dela critérios de análise mais ético-moral que literários.

Palavras-chave: ilusão, romance, estrutura, percepção, recepção

\section{Abstract:}

As Ilusões do Romance: Estrutura e Percepção em São Bernardo de Graciliano Ramos is a study and analysis of the narrative, of the effects produced by the act of reading (ISER: 1996) and ending with a historical perspective of the novel at the moment of his publication (1934). In order to contemplate the last aspect, it made use of the aesthetic of reception (JAUSS: 1994). So, in conformity to this succession, the work proposes the following hypothesis: namely, that the novel's personages are masks of literary patterns. That was allowed to the author of São Bernardo to criticize the conventionality of some literary ideals by that time. What is almost the same observed by Bakthin in the novels of Dostoiévski and which he named dialogism. The novel's personages of Graciliano Ramos are effects from illusions produced by literary ideals embodied and established in his actions. Therefore, São Bernardo allows many interpretations. In general, the second novel of Graciliano Ramos has been read like a confession of the author's style: by Paulo Honório apparently to be a kind of narrator who hardly would write a book, most readers are induced to make choice of the morale criteria of valuation, instead of a methodology of literary analysis: what intercepted a modern point of view into São Bernardo.

Key-words: illusion, novel, structure, perception, reception 


\section{APRESENTAÇÃO GERAL}

São poucas as obras literárias que, em seus níveis de elaboração artística, abrigam material de estudo plenamente capaz de atrair os mais diversos interesses, sejam estes contemporâneos à obra, sejam posteriores ao surgimento dela, num ponto do passado. Tais obras têm a virtude de produzir conflitos, polêmicas, dialogar com vários tempos e provocar as atenções das mais diversas áreas do conhecimento em suas trajetórias no tempo. São poucas. Isso não significa, porém, que a maior parte delas seja carente de articulações com virtude de ecoar em todos os níveis da estrutura do texto e potencializar sua ressignificação de tempos em tempos. É, por sinal, dessa possibilidade de o "mesmo" ter significação diferente e contrária em outras situações que advém a maior parte das polêmicas geradas no campo literário e torna as obras objeto de reflexão e disputa permanentes.

Assim, se há as que produzem polêmicas pontuais, cristalizando-se até a paralisia, há outras que polemizam por si mesmas, pelo simples fato de existirem num tempo que já não mais as admite: elas se rebelam frequentemente, à menor mudança do tempo ou do mundo em que pareciam estar alojadas. Libertam-se de saberes que pareciam dar conta de sua natureza e exigem outros saberes; motivam as atualizações de teorias e modelos a fim de se adequarem a novos tempos. Nada as detém. Fogem permanentemente da nossa compreensão. Tais obras fazem com que tenhamos a prudência de saber que sobre elas nosso conhecimento será provisório. Só restará, ao final, “(...) o sulco geralmente aberto no espírito pelas grandes

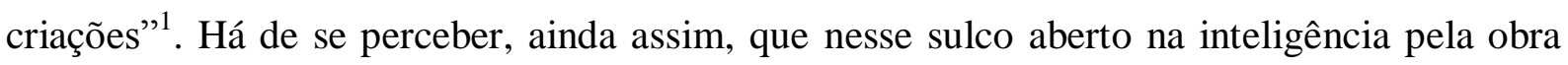
imprimem-se os contornos da forma que por ali passou.

\footnotetext{
O leitor não contemporâneo [da obra] é por isso obrigado, não só a estabelecer uma relação com o texto, mas ao mesmo tempo a reconstruir os repertórios de que dispunha o receptor da comunicação original. No entanto, esta reconstrução nunca poderá restituir o horizonte original da experiência; ela não passa de relativa e particular, pois possibilitada por uma conceitualidade explícita. ${ }^{2}$
}

Assim é que, diante de um romance como São Bernardo, e dos estudos por ele gerados ao longo de seus 75 anos, percebe-se como participa desse universo de obras. Não raras, mas poucas. O que leva a uma pesquisa ou análise, de imediato, necessitar visceralmente da compreensão dessa riqueza constituída a posteriori. E, para compreendê-la,

\footnotetext{
${ }_{1}^{1}$ CANDIDO, Antonio. Ficção e Confissão, In: RAMOS, Graciliano. São Bernardo / São Paulo: Martins, 1972.

${ }^{2}$ STIERLE, Karlheinz. "Que Significa a Recepção dos Textos Ficcionais?” In: JAUSS, H. R. at all; (coordenação e tradução de Luiz Costa Lima). A Literatura e o Leitor, Rio de Janeiro: Paz e Terra, 1979. (Cf. p. 173)
} 
nada mais trivial do que investigar como isto tudo está arquitetado, a partir de como o romance está construído e se apresenta no momento em que se entra em contato com ele. É a partir daí, do que ele significa nesse primeiro momento, que podemos discernir o que significou, para este ou aquele crítico, e o que talvez já nem mesmo possa mais ser atualizado com o mesmo significado.

Não nos interessa mais dar um salto ao passado remoto do que compreender o presente imediato. É nosso dever compreender a ordem dos atos da compreensão tais como eles se dão; e, de imediato, o primeiro passo do entendimento refere-se ao presente. Assim sendo, o passado surge sob o pano de fundo da atualidade do sentido. Antes de tudo, portanto, discerniremos o passado no presente. Um passado que continua ativo e que faz parte do nosso horizonte de compreensão. Tais saltos ao passado, sem a devida reflexão a respeito do presente e do passado nele presentificado, trazem consigo o risco de confundirmos a nós mesmos num momento que não poderíamos vivenciar, tampouco existir: segundo Stierle, não é possível reconstruir essencialmente a experiência vivida da recepção original e com isso concordamos plenamente.

Daí o momento atual ser decisivo para que toda compreensão possível seja alcançada: o percurso aparentemente natural de vasculhar os primórdios de uma obra para restaurá-la no presente se torna enganoso; "no passado" nada mais faremos do que buscar e explicitar a nós mesmos, nosso próprio presente, se não estivermos munidos da compreensão de que se trata de outro modo de compreender os mesmos signos, as mesmas articulações simbólicas.

Assim, adotaremos, nesta pesquisa, o percurso inverso da suposta ordem lógica e natural dos processos de busca e compreensão histórica: a saber, o processo ilusório de vir do passado à atualidade. É preciso proceder como se remássemos contra a corrente de um rio para chegarmos à sua nascente. Porque, no final das contas, é este o único e possível procedimento concreto que se realiza em qualquer pesquisa dessa natureza.

O estudo que se desenvolverá neste trabalho dialoga primordialmente com as principais leituras e análises críticas publicadas nos últimos anos, com quais todos estão mais ou menos habituados; são elas a base de entendimento de São Bernardo e que, de certo modo, orientam a compreensão do romance no sentido de obra tanto para o pesquisador como para seu leitor atual. Isso para não dizer que certos aspectos interpretados dela participam do campo semântico geral da cultura; que compõe nosso horizonte de 
compreensão na atualidade. Um exemplo disso é o caso da assunção completa, pelo ponto de vista atual, de que o traço do caráter do protagonista do romance, o "sentimento de propriedade", é um sentido substancial, uma verdade absoluta e como que sem autoria, inerente ao romance, e não, por exemplo, uma leitura ou hipótese interpretativa histórica formulada por Antonio Candido. Essa interpretação arraigou-se às perspectivas de leitura geral de tal modo que hoje é uma espécie de lugar-comum, tamanha abrangência, difusão e autonomia alcançou. Não se cita Candido como autor dela. O "sentimento de propriedade" é tomado como algo existente em si mesmo, sem origem, como uma verdade do romance. $\mathrm{O}$ que se constitui como uma das mais bem-sucedidas interpretações realizadas sobre o caráter do protagonista.

Por ter-se alojado ao horizonte de compreensão de nossa época, não sendo mais considerado da autoria do crítico paulista, o conceito é generalizado hoje como propriedade comum. Por isso a necessidade de compreender o horizonte de expectativas contemporâneo antes de nos aproximarmos do passado. Só assim o passado pode se destacar do pano de fundo do presente, não permitindo enxergarmos nele a nós próprios ou qualquer coisa que dele não faça parte.

\footnotetext{
"Quanto mais o tempo passa, a tarefa preliminar dos críticos posteriores consistirá na interpretação do que surpreende e espanta, do conteúdo material da obra. [Continua Stierle citando essa passagem dos Escritos de Walter Benjamin] Eles se tornam comparáveis a um paleógrafo diante de um pergaminho, cujo texto apagado é recoberto pelos traços de uma escrita mais forte, que lhe superpuseram. Assim como o paleógrafo deveria começar pela leitura dessa segunda escrita, assim também o crítico deve começar pelo comentário.”3
}

A noção de "sentimento de propriedade" exemplifica esse fenômeno de incorporar ao nosso ponto de vista algo construído por uma época ou por um autor como segunda escrita. Tomemos nota de que ela não existiu antes de Ficção e Confissão ter sido publicado pela primeira vez na década de 1950 em jornal. E, ao estudar-se a recepção crítica entre 1930 e 1940, estar-se-ia perigosamente referindo-se a Antonio Candido - sem se saber ao certo, exatamente por termos incorporado substancialmente essa noção como propriedade do texto. Assim, sempre que algo lá, qualquer menção ou palavra, a "denotasse" por algum tipo de semelhança em detrimento do significado próprio de época, o passado, de fato, deixaria de existir para dar lugar a uma compreensão que a ele jamais pertenceu.

\footnotetext{
${ }^{3}$ Idem. p. 175
} 
Sabemos, por exemplo, que Carlos Lacerda, nos anos de 1930, foi quem primeiro tocou na questão da "propriedade privada" como elemento desencadeador de efeitos de comportamento e ações alienantes que tornam o personagem insensível a determinados aspectos humanos. A hipótese de Lacerda é, no entanto, completamente inversa do que se passou a considerar quase chave do romance: o protagonista, para ele, perde seu potencial de sensibilidade ao ser absorvido gradualmente pela conveniência do mundo dos negócios e das relações capitalistas, num processo de aniquilamento moral e humano que progride à medida que Paulo Honório vai ascendendo; o que o leva, consequentemente, à desumanização final, ao drama de consciência. É na transição do homem de seu estado simples de vida para o modo complexo do homem socializado no mundo das relações capitalistas que Lacerda detém o olhar e apura, finalmente, que, se houvesse uma revolução, não haveria homens para serem destruídos, mas um sistema e um modo de vida ${ }^{4}$. Antonio Candido interioriza isso tudo em Paulo Honório, atribuindo-lhe um estado psicopatológico de "sentimento de propriedade", origem da construção exterior do poder e destruição interior de si mesmo. Não há um sistema fora de Paulo Honório que explique sua degradação senão o "sentimento inato que o domina".

Entre as décadas de 1930 e 1950, portanto, havia uma perspectiva de leitura crítica de São Bernardo que não se repetiria mais nem achou qualquer tipo de continuidade: a crítica ali se ocupava mais com o combate do socialismo/comunismo; ou, este último, do combate às tendências de direita, quase sempre associadas ao catolicismo; ou em reproduzir um ideal, em literatura, de revolta do proletariado; ou de resolução dos problemas sociais pela explicação místico-religiosa; fundamentalmente com questões mais voltadas para a moralização/humanização da prática literária do que para seus fundamentos artísticos de prática simbólica ou estética. Evidentemente, esses mesmos aspectos, conforme determinados autores, não deixavam de ser pensados em caráter simbólico ou estético, do qual nos chegam as melhores obras desse período. É, pois, um tempo turbulento, duma gravidade assombrosa na literatura, que se volta sobre si mesmo e ignora tudo que não seja suas próprias demandas imediatas 5 . Pouco se observou, por exemplo, sobre os efeitos do sistema de acúmulo capitalista no comportamento social, em termos estéticos ou teóricos - o que viria a ser um dos pontos mais discutidos nos anos de 1970.

\footnotetext{
${ }^{4}$ Todos os textos colhidos ao longo da pesquisa estão disponíveis no último capítulo deste trabalho. ${ }^{5}$ Abordaremos esse aspecto com mais propriedade, a partir de estudos como o de Luís Bueno, Uma História do Romance de 30.
} 
Percebe-se claramente que há no mínimo três estágios do desenvolvimento da leitura e interpretação crítica de São Bernardo. A dinâmica desses três estágios ou momentos históricos não se apresenta com um sentido de evolução de ideias. Pode-se dizer que há, entre os anos de 1950 e 1970, certa complementaridade em termos de raciocínio crítico. Mas nada do que tenha surgido a partir daí foi consequência de um postulado produzido nos anos de 1930. Esse dado tornou perturbador o intento de começar a apresentação do percurso desta pesquisa e estudos linearmente, de um ponto de partida do passado à atualidade. E principalmente se evidenciou artificial esse modo de engendrar a dissertação à medida que fomo-nos conscientizando de que, antes de entrar em contato com os primórdios das publicações, já havíamos analisado a obra e estudado a crítica contemporânea, assimilando-a. A verdade é que adotar essa ordem contrária só corresponde à inversão de uma lógica de compreensão histórica e generalizada de leitura, mas não a inversão do caminho naturalmente executado por qualquer estudante ou pesquisador.

Gostaríamos que se compreendesse, assim, que o estudo desses momentos da recepção crítica de São Bernardo não é nem origem nem gênese desta pesquisa. Embora nele presente, sua condição inicial foi de orientação para o sentido da obra, não objeto de uma reflexão sobre sua historicidade. Porque, antes de tudo, havia e há uma tese a ser defendida a respeito desse romance, que nos levou a percorrer o passado em busca de "provas". São Bernardo parecia-nos ter sido construído como crítica às linguagens literárias existentes, não mais capazes de dar conta da nova situação artística, cultural e ideológica de sua época. Seus personagens mover-se-iam segundo os ideais literários implícitos no processo discursivo do romance, enquanto que a realização formal e estética do livro funcionaria como a contrapartida deles ou conciliando as perspectivas literárias existentes no âmbito do romance como coordenadas da produção realizada pelo autor. Essa percepção levou-nos a pesquisar até que ponto isso seria possível, daí resultando a tese de que, em São Bernardo, temos a teatralização de ideais literários, como consciência e concepção de mundo dos personagens, postos em movimento dramaticamente no plano geral do romance. Sendo eles modo de ver vinculado a convenções literárias ou filosóficas do romance, a dramatização os desmascararia diante do leitor, em termos de fundamentos ideológicos e de prática artística falseada do modo de ver a realidade, como se fossem modelos incapazes de dar conta dos problemas sociais ou do mundo imediato. São Bernardo seria, assim, um romance crítico, mas crítico pela sua própria elaboração artística em contraste com os ideais inequívocos ali 
exibidos em forma de consciência de personagens. As ações destes estão vinculadas a ideais característicos de elaboração romanesca, o que adiante abordaremos de modo mais explícito.

Este é, portanto, o objetivo inicial a que se propõe esta pesquisa em seu primeiro estágio de realização e de que antes se tomará conhecimento. Não foi o estudo isolado da recepção crítica ao longo da vida dessa obra nossa preocupação inicial, mas buscar em sua origem, nos anos de 1930, elementos que fundamentassem nossa tese. Mas o que se verificará, a seguir, é que o percurso dessa busca revelou mais que isso. Daí nossa preocupação de manter o processo de pesquisa tal como ele se desenvolveu. Para nós, isso corresponde ao que Antonio Candido caracterizou em seu ensaio como "o sulco aberto pelas grandes obras". Cremos que o próprio romance e sua história produziram essa reflexão. Sendo ela mesma já um efeito da própria estrutura formal do romance, que ao final, em seu último capítulo, parece-nos solicitar que voltemos ao capítulo 1 para que possamos compreendê-lo. 


\section{PRIMEIRA PARTE}

\section{Introdução}

Apesar de parte da crítica produzida na década de 30 ter sido incorporada ao corpus da pesquisa, ela não será o objeto de nossa preocupação inicial. Exatamente por aceitarmos o conceito de "obra" teorizado por Wolfgang Iser, segundo a ideia de que é o ser constituído na consciência do leitor a partir da relação dialética entre leitor/texto em um dado contexto e momento histórico. Nesse sentido, o texto depende do leitor, mas este último não tem a primazia, porque é o texto que lhe fornece os elementos que se articulam e se atualizam em sua consciência em forma de sentido e significado. De modo inverso, então, o significado atribuído ao texto não está lá, apenas esperando a atualização referencial do leitor: ambos participam de uma relação dialética determinada pelos elementos estruturais discursivos do texto. E, pelo fato de que esses elementos passam pelo filtro de uma compreensão histórica, datável - esteja esse filtro (conjunto de normas de leitura e interpretação) na consciência do crítico ou no horizonte de expectativas de uma época -, outros elementos acabam sendo deixados de lado. Por isso, a análise estrutural do romance, primeira etapa de nossa pesquisa, terá como finalidade organizar as relações possíveis de articulação entre os elementos internos da obra, possibilitando identificar em que parte da rede de relações inerente ao texto a consciência ativa do leitor abasteceu-se para produzir as significações. Ou seja, o texto funciona como uma instrução de jogo pela qual o leitor pode ou não se orientar.

Um exemplo dessa transação pode ser compreendido com a análise semântica da expressão "língua de Camões", que surge logo no primeiro capítulo do livro: há o sentido da obra de Camões aí, ou o sentido do uso correto da língua culta padrão e até mesmo o uso da expressão como referência ao estilo parnasiano. Ao se atribuir um desses significados à expressão, já não estamos mais tratando do texto, mas de um valor epocal atualizado e determinado pelo leitor, segundo suas próprias orientações ou segundo o significado que a expressão possa ter adquirido numa época: por exemplo, o significado de haver, na aparente recusa da "língua de Camões", uma postura modernista por parte do personagem-escritor não faz parte do texto em termos de significado exclusivo: Paulo Honório ignora completamente o que é literatura e seus valores estéticos e simbólicos; daí esse significado ser frequentemente atribuído ao escritor Graciliano Ramos, produzindo certa contradição devido a suas supostas recusas do movimento modernista de São Paulo. Dois momentos que não se equivalem - o da 
percepção do sentido e o da atribuição de um significado para o sentido -, portanto, estariam implicados aí: uma relação dialética texto/leitor, cuja força de produção simbólica só se realizará nessa condição ${ }^{6}$. Daí a necessidade de mostrar discernidas as articulações de sentido, inerentes ao texto, do parecer crítico explicitado. Pois há certos espaços abertos, vazios do texto, intervalos temporais etc., em que a interpretação, a concatenação de ideias ou atribuição de sentido, se realizarão determinadas pelo ato de leitura que articula os elementos internos do texto conforme determinada norma.

Por isso é que o texto terá a primazia na pesquisa, não o leitor isolado e nem mesmo o autor: não é possível estudá-los de modo isolado e falar de estrutura do romance. A obra só é autônoma aparentemente, pelos os efeitos de ilusão produzidos pelas orientações do senso ou do valor literário de uma época.

O objetivo central deste trabalho, portanto, será a análise estrutural do segundo romance de Graciliano Ramos, São Bernardo, publicado em 1934, conforme as noções teóricas da semiótica; a partir daí, será reconstruída a rede relacional do sistema de sentido do texto para, em seguida, confrontá-la com as hipóteses e pressupostos da crítica. Partindo-se de que o texto tem regras e limites, como um jogo de xadrez, será examinado como se inicia, com que tipo de interlocutor dialoga etc., para, num segundo momento, confrontar a análise da estrutura com o juízo crítico manifestado ao longo da história do romance, identificando em quais aspectos estruturais se fundam as manifestações da recepção, segundo a noção de intersubjetividade: "A multiplicidade das interpretações de um texto indica que estas seleções subjetivas não são idênticas, mas passíveis de compreensão intersubjetiva, uma vez que representam tentativas de otimizar a mesma rede relacional."’7

Como já havíamos nos referido no início desta introdução, portanto, a compreensão que temos de um romance não é um juízo isolado de outros; todos participam juntos, sejam concordando ou divergindo, para que o sentido global de obra se manifeste como conhecimento geral e comum, dado de uma época ou cultura. Essa compreensão geral não é a obra em si, mas a soma de leituras realizadas com êxito reconhecido e que orientam o significado

\footnotetext{
6 "Northrop Frye has referred to an attack on Jakob Böhme which aptly describes the conditions leading to the reader's act of production: 'It has been said of Boehme that his books are like a picnic to which the author brings the words and the reader the meaning. The remark may have been intended as a sneer at Boehme, but it is an exact description of all works of literary art without exception"”. ISER, Wolfgang. The Implied Reader: Patterns of Communications in Prose Fiction from Bunyan to Beckett / The Johns Hopkins University Press: Baltimore and London, 1987. (Cf. p. 30)

${ }^{7}$ ISER, Wolfgang. O Ato de Leitura: Uma Teoria do Efeito Estético vol. 2 / trad. Johannes Kretschmer - São Paulo: Ed. 34, 1999. (Cf. p. 27)
} 
geral que temos de um romance numa época. Daí, outra etapa deste trabalho ter como base teórica a estética da recepção surgida na Alemanha, nos anos de 1960, assim como, intermediariamente, a teoria do efeito estético de Wolfgang Iser, em $O$ ato de leitura: uma teoria do efeito estético. Se por um lado a obra é a soma das interpretações realizadas pelos leitores, elas só podem ter como origem o texto literário, donde se extraem os significantes de sentidos possíveis e, num segundo momento, implanta-se um significado; além disso, o texto continua, ad infinitum, produtor histórico de significado, motivo de que também se esteja sob as influências dele e do tempo em que se participa ativamente, produzindo outras interpretações. Sendo assim, a tese que defenderemos aqui é própria de nosso tempo. É uma intervenção no texto legítima e necessária, que não poderia sequer existir sem a contribuição das leituras legada pela história desse romance, bem como pela contribuição de sua própria estrutura.

Assim, a análise estrutural nos permitirá compreender a multiplicidade das interpretações realizadas e possíveis; isto é, em que parte da rede relacional do texto a consciência ativa do leitor abasteceu-se para produzir o significado que lhe foi e lhe é atribuído. Não nos interessa necessariamente a interpretação, mas o caminho dela: não é objetivo desta pesquisa brigar com as interpretações ou corrigi-las, mas discutir seus pressupostos teóricos e hipóteses (porque estes partem do texto literário ou de uma rede intersubjetiva que pode ser confirmada ou não na estrutura textual). Uma interpretação não pode ser questionada, a menos que haja um equívoco no processo. Mas seus pressupostos têm caráter intersubjetivo, ou seja, apresentam aparência de objetividade sem o sê-lo realmente, sendo passíveis de uma análise histórica.

Gostaríamos de demonstrar também, a partir desse procedimento de análise, de que modo algumas noções literárias suscitadas por São Bernardo percorrem a história do romance e se transformam nos períodos nos quais transitam sob o efeito dos novos contextos de leitura. Nossa tese acerca dessa obra é a de que ela foi construída a partir da reflexão sobre um novo paradigma de romance, que implicava a experimentação de possibilidades linguísticas e literárias diversas. Evidentemente, isso se liga ao próprio contexto em que Graciliano Ramos se insere historicamente:

O romance, desde os inícios do século $[\mathrm{XX}]$, vem abandonando nitidamente os caminhos da narrativa aprazível de tempos passados, procurando abranger a nova realidade, inicialmente em algumas obras experimentais, e mais recentemente em maior escala. Essa nova experiência da realidade liga-se intimamente a um renovado sentimento linguístico, que - libertado das limitações do pensamento lógico, 
científico e da análise factual - se projeta no mundo como possibilidade ou tentativa de uma nova e genuína expressividade ${ }^{8}$.

Nesse sentido, São Bernardo ofereceu um permanente debate sobre as formas romanescas (realizado muitas vezes indiretamente). Isso poderá ser demonstrado a partir das próprias relações dos personagens: elas não só representam modalidades dramáticas como se desenvolvem com base em algumas concepções e hipóteses de construção literária discutidas desde 1920 mais ou menos (sem que se pudesse abandonar ou relegar totalmente ao esquecimento algumas concepções do século XIX). Ou seja, Graciliano teatraliza nas relações dos personagens certas concepções sobre a arte em forma de conduta (inevitavelmente políticoideológica), por meio da construção de um autor fictício pouco estudado e praticamente sem congêneres na literatura, se não observássemos, por exemplo, embora com muita cautela, um personagem como Leopold Bloom, do Ulisses de James Joyce, aflorando sob o fluxo de sua consciência, na narrativa, aos nossos olhos, como pessoa vivíssima num dia comum ${ }^{9}$; assim como os autores fictícios de Machado de Assis também devam ser observados aqui (contudo, nesse caso, Graciliano segue uma direção bem diferente). A título de exemplo, tomemos um pequeno fragmento de São Bernardo que vai muito além do que se identificou como "monólogo":

(...) Não pretendo bancar escritor. É tarde para mudar de profissão. E o pequeno que ali está chorando necessita que o encaminhe e lhe ensine as regras de bem viver.

- Então pra que escreve?

- Sei lá.

O pior é que já estraguei diversas folhas e não principiei.

- Maria das Dores, outra xícara de café.

Dois capítulos perdidos. Talvez não fosse mau aproveitar os do Gondim, depois de expurgados. ${ }^{10}$

O que esse trecho revela é que entre a narração, seu espaço e tempo, e os processos discursivos, no modo direto, enquanto recurso da atuação de personagens na cena, num certo espaço e tempo distintos, não há limites claros, podendo ser interpretados de duas maneiras: conforme os padrões da literatura do final do século XIX, em que os aspectos de espacialização e temporalização da narração distinguem-se por oposição ao espaço e tempo cênicos das ações dramáticas dos personagens (o que constituiria o trecho “Então pra que escreve?”, jun-

\footnotetext{
${ }^{8}$ ROSENTHAL, Erwin Theodor. O Universo Fragmentário / trad. Mário Fleicher. São Paulo: Ed. da Universidade de São Paulo, 1975. (Cf. p. 37)

9 "Tudo depende do ângulo de visão e da compreensão dos problemas. Por outro lado, nada seria mais errôneo do que afirmar que Ulysses apresenta de fato um relato realista.” (ROSENTHAL, 1975: p. 17)

${ }^{10}$ RAMOS, Graciliano. São Bernardo / Rio de Janeiro: Record, 1984. (Cf. p. 11)
} 
tamente com a resposta, como discurso indireto livre); e, dum outro ângulo, e bem mais plausível que o primeiro, em que os espaços e os tempos são simultâneos, fundindo narração, narrador e processos discursivos próprios da ação dramática dos personagens num lugar diferente dos realistas ou naturalistas.

Perceba-se que o mesmo recurso de discurso direto que recai como pergunta sobre a narração também é usado como recurso das ações discursivas dos personagens em cena: o trecho em que o narrador pede outra xícara de café não se comporta da mesma forma que a pergunta "Então pra que escreve?": se esse recurso pode ser interpretado como "fala na consciência" do narrador, o pedido pela xícara de café, tendo aplicação idêntica, desmente a ideia de monólogo. Essa fusão dos espaços e simultaneidade dos tempos põem em perspectiva o narrador in loco, de modo a possibilitar vê-lo em plena atividade mental, sem os esquematismos psicológicos até então desenvolvidos nos romances do século XIX. Poder-se-ia dizer que tal trecho é acidental. Mas a ocorrência dele é apenas desenvolvimento de um anterior: já sabíamos que Casimiro Lopes estava ali, acocorado ao lado do narrador, que se debruça sobre as folhas que tenta escrever:

\footnotetext{
Casimiro Lopes me pergunta se me falta alguma coisa.

- Não.

Casimiro Lopes acocora-se num canto. Volto a sentar-me, releio estes períodos chinfrins.

Ora vejam. Se eu possuísse metade da instrução de Madalena encoivarava isto brincando. ${ }^{11}$
}

Aqui há o mesmo processo. Paulo Honório está na janela da sala. Casimiro Lopes lhe faz a pergunta. Ele responde segundo o uso comum do recurso do discurso direto. Mas essa última sentença de nossa citação contém um elemento muito claro de oralidade: o "Ora vejam”, expressão situacional da fala, funcionaria como introdutor de diálogo, discurso direto, do mesmo modo que o travessão. De onde nos vem a sensação de que o narrador literalmente fala. Quase se poderia dizer que o vemos levantar a cabeça, pôr o dedo na vertical, olhar aos protagonistas e dizer: "Se eu possuísse a metade da instrução de Madalena encoivarava isto brincando." É evidente que ele não está escrevendo o que lemos, esse dado torna-se interpretação, orientado pelo texto, que nos fornece uma forma familiar não explicitamente idêntica ao modelo de que temos conhecimento. A forma do texto de Graciliano lembra, ativa e desperta a memória de narradores-escritores semelhantes aos de Machado de Assis, Edgar Alan Poe, Dostoiévski etc., sem sê-lo.

${ }^{11}$ Idem. p. 10 
Essa característica do texto de São Bernardo não foi algo isolado da prática de Graciliano. Leticia Malard percebe o mesmo processo em Vidas Secas, supondo também um recurso diferente daqueles encontrados nos romances do século XIX:

\begin{abstract}
Não é preciso chamar a atenção do leitor de Vidas Secas para a incidência do discurso indireto livre em suas páginas. (...) Entretanto, convém observar a impossibilidade de se distinguir com clareza algumas das modalidades de discurso narrado, não só em Vidas Secas como também na complexidade do discurso literário dos romances modernos. Daí acreditarmos serem extremamente perigosas quaisquer conclusões analíticas que pretendam diferenciar os monólogos interiores de personagens da fala do narrador em Vidas Secas $(. . .)^{12}$.
\end{abstract}

Curiosamente o mesmo pode ser dito de São Bernardo, ainda que o romance tenha sido escrito em primeira pessoa. O que parece não ter sido observado nessa obra foi exatamente o fato dialógico: a pergunta "Então pra que escreve?" recai sobre as digressões do narrador e parece ter sido feita por um personagem exatamente porque o pedido pela xícara de café é realizado através do mesmo e idêntico recurso. Logo, como e quem ouviu seus pensamentos (ou, numa das hipóteses mais corriqueiras da crítica, quem leu o que ele estava escrevendo, sendo sua narrativa interpretada como a própria escrita)? Maria das Dores? Casimiro Lopes? Há duas hipóteses apenas: uma, segundo a noção teórica de dialogismo de Bakhtin, na mente do personagem. A voz que o interroga está dentro dele. Contudo, o problema gerado pelo recurso do discurso direto, posteriormente usado para indicar a fala do personagem Paulo Honório, na cena, fazendo o pedido da xícara de café ou recusando a ajuda de Casimiro Lopes (o que o torna contemporâneo da dramatização cênica e narrador ao mesmo tempo) é que temos aí uma alternativa de pensar a onisciência de personagens, o que seria absurdo. Mas, se eles escutam a narrativa ou a digressão de Paulo Honório, então se produz a simultaneidade dos espaços narrativos e dramáticos.

Daí não se tratar de monólogo interior. Mais lógica seria a interpretação de que essa narrativa é uma espécie de descrição do fluxo mental dum autor-suposto, narrando in loco ou "pensando alto", aspecto da arte tão caro aos movimentos de vanguarda, que procuravam no fluxo da consciência humana um novo paradigma de percepção artística da realidade. Tal processo é o mesmo utilizado por James Joyce em Ulisses, em que o apagamento do narrador tradicional é marcante, cujo mecanismo de operação já não pode ser mais descrito como discurso indireto livre; pelo contrário, pois isso pressupõe uma coordenação hierárquica dos ní-

\footnotetext{
${ }^{12}$ Idem. (Cf. p. 97)
} 
veis de discursos, dos espaços e tempos na narrativa em franca oposição com os espaços e tempos cênicos.

Vejamos esse apagamento do narrador tradicional abundantemente desenvolvido em Ulisses. O trecho a seguir foi tirado daquele ponto em que Bloom, após o enterro de Dignan, sente fome e entra em uma lanchonete:

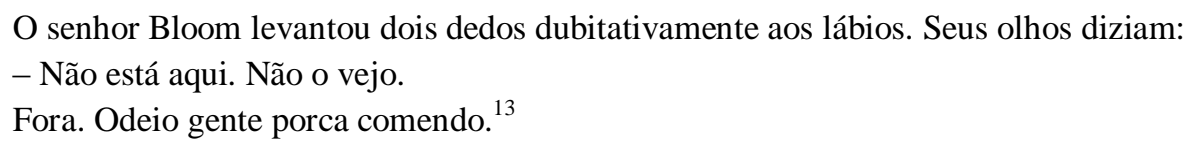

Há nesse pequeno fragmento três modalidades de discurso diferentes: o primeiro é convencional, em 3. ${ }^{a}$ pessoa, com um verbo discendi (diziam), juntamente com o travessão, indicando o discurso indireto livre (o que convencionalmente denunciaria a estrutura psicológica do personagem); mas o terceiro processo narrativo é totalmente atípico, desnaturalizando o primeiro recurso e desmascarando-o como falseamento de representação de estruturas psicológicas, tornando-o artificial: esse terceiro processo discursivo assume certo aspecto humano, além de narrar por conta própria, sem intromissão do narrador em $3^{\mathrm{a}}$ pessoa (característica duma arte mais condizente com a modernidade do romance do século XX, como bem advertiu Letícia Malard), assim como pondo em dúvida a quem ele poderia ser atribuído.

É nesse sentido de pesquisa que nos orientaremos, buscando os elementos e processos da obra em termos de literatura modernista (já que o termo moderno não dá conta da caracterização desse tipo de recurso por abranger uma literatura praticada desde o fim do século XVIII), juntamente com suas categorias e pressupostos de análise por parte da crítica. Aqui o termo "modernista" apenas tem o sentido de evitar confusão com a generalidade do "romance moderno". São muitos os índices que sugerem tal ruptura artística de São Bernardo com o romance tipicamente produzido, no Brasil, até por volta do fim do século XIX e início do XX. Não só o observado acima. Mas pelo fato de que a proposta desse romance tem como um de seus correlatos a de Mário de Andrade, segundo o percurso da nova orientação estética por ele defendida.

31 O impulso clama dentro de nós como turba enfurecida. Seria engraçadíssimo que a esta se dissesse: “Alto lá! Cada qual berre por sua vez; e quem tiver o argumento mais forte, guarde-o para o fim!” A turba é confusão aparente. Quem souber afastar-se idealmente dela, verá o imponente desenvolver-se

\footnotetext{
${ }^{13}$ JOYCE, James. Ulisses / trad. Antônio Houaiss. Rio de Janeiro: Civilização Brasileira, 2008. (Cf. p. 222)
} 
dessa alma coletiva, falando a retórica exata das reivindicações. ("Prefácio Interessantíssimo" / Mário de Andrade)

A multiplicidade de vozes dentro do indivíduo, caracterizada como turba, conteria, para Mário, certa organização completamente diversa das hierarquias convencionalmente conhecidas na arte literária e poética. Dessa perspectiva é que ele propôs a modernização da literatura, muito próximo do que Bakhtin teorizou como dialogismo na obra de Dostoiévski, caracterizando-a como polifonia. Ora, muito se falou de São Bernardo e seus dois primeiros capítulos como uma espécie de desorientação do narrador, espécie de confusão ou desnorteio. Parafraseando Álvaro Lins, como se ele ainda não tivesse definido a linha mestra de raciocínio por qual se orientaria. E, de fato, o narrador vai refletir ao longo da narração sobre o que contou e como poderia alcançar melhor efeito se construísse determinados pontos de outro modo.

Note-se como um paralelo do texto de Mário de Andrade um trecho de discurso do narrador de São Bernardo ao pensar em como vai escrever (a indicação futura significa que ainda não escreveu): "De resto isso vai se arranjando sem nenhuma ordem, como se vê."

Poderíamos parafrasear Mário de Andrade aqui e repetir que "seria engraçadíssimo" que Paulo Honório, depois de afirmar não ter a menor noção de literatura, iniciasse sua narração construindo quadros, cenas ou sumários narrativos encadeados num processo espacial e temporal específico da literatura tradicional. E é daí que surgem os estranhamentos de Antonio Candido e João Luiz Lafetá ao confirmarem a ausência de cenas ou de descrições abrangentes na construção de São Bernardo.

Pressupõe-se, neste trabalho, que Paulo Honório narrador é, de modo diferente, mas com o mesmo objetivo, espécie de teorização de uma escrita mais condizente com o modo de operar da mente humana, que vai apagando certos vestígios das convenções literárias do século anterior, apesar da manutenção de certos usos e aspectos formais tradicionais. E nem sempre o escritor Graciliano Ramos concorda com o narrador Paulo Honório, e vice-versa - consideração que será explicada mais adiante.

Rui Mourão escreveu sua crítica sobre esse processo conforme a ideia de que os capítulos 1 e 2 representariam uma espécie de concretização do desnorteio de Paulo Honório, que indicaria sua falta de conhecimento da arte literária. A aparente falta de ordem na construção do romance se justificaria, portanto, por harmonizar-se com a personalidade de Paulo Honório. Osman Lins, posteriormente, vai contrapor a essa explicação o fato de que a desor- 
dem, na verdade, não existe. Pelo contrário, ela é apenas uma forma de organização diferente do que se havia feito até então.

\begin{abstract}
Afirma Rui Mourão, em linha totalmente oposta à do autor do Jornal de Crítica [Álvaro Lins]: "a técnica da composição do romance adquire extraordinário relevo à medida em que documenta concretamente a inabilidade do narrador, que não sendo, como confessa, um escritor, só pode contar com um estilo claudicante". Continua, reforçando a apreciação: "A forma de iniciar a narrativa também documenta a sua imperícia”. Deduz-se, de tais constatações, que o romancista - optando, com uma espécie de maestria às avessas, pela representação da inexperiência literária do seu personagem-narrador - reduziria essas páginas iniciais a um solilóquio perplexo: o texto apenas exprimiria a sua confusão ao lidar com palavras, material tão diverso daqueles com os quais Paulo Honório vem abrindo na vida o seu caminho. ${ }^{14}$
\end{abstract}

Enquanto Álvaro Lins qualifica o processo como inverossímil, Rui Mourão o descreve e dá-lhe um valor positivo. Evidentemente, a escolha de um narrador semialfabetizado, sem conhecimento de literatura, justifica essa ausência aparente de ordem e possibilita experiências novas. As formas burguesas de representação literária, em São Bernardo, surgem apenas como pano de fundo, na memória do leitor, contra uma linguagem literária aparentemente desordenada. E um dos principais efeitos dessa construção no leitor é o de estranhamento, recusa, repulsa absoluta diante de tal narrador e personalidade; a explicitação de seu modo de raciocinar em forma de literatura, aparentemente rudimentar e brusca, produz tal efeito no leitor. O qual não se menciona jamais segundo o ponto de vista de efeito estético, fruto do contraste entre o padrão conhecido e memorizado pelo leitor com a novidade; esse efeito apenas pode ser aferido a partir da recepção, que o deixa transparecer em forma de juízo efetivamente emocional ou moral, num primeiro instante, e, em seguida, como síntese teórica literária ou interpretativa. O fato de Paulo Honório subordinar a organização do romance, em seus planos iniciais, ao modo capitalista de "divisão do trabalho" causa certa repugnância, ocasionando, por implicação, um leitor suposto. O caso é que a análise estrutural pode nos oferecer oportunidade de conferir no texto, realização concreta do escritor e produtor histórico de sentido, o modo ou forma de ele dirigir a sensibilidade do leitor.

Em face do texto, surgem no nosso espírito certos estados de prazer, tristeza, constatação, serenidade, reprovação, simples interêsse. Estas impressões são preliminares importantes; o crítico tem de expe-

\footnotetext{
${ }^{14}$ LINS, Osman. "Homenagem a Graciliano Ramos” In: BRAYNER, Sônia (org.) Graciliano Ramos, Coleção Fortuna Crítica / Rio de Janeiro: Civilização Brasileira, 1978. (Cf. p. 190)
} 
rimentá-las e deve manifestá-las, pois elas representam a dose necessária de arbítrio, que define a sua visão pessoal. ${ }^{15}$

Um dos estados mais comuns surgidos da leitura de São Bernardo é o de reprovação, repulsa e indignação diante da brutalidade e da aspereza do protagonista. Anular esse efeito do texto permite-nos objetivar as reações e, assim, conferi-las na base da narrativa, bem como observar nossas próprias reações. Confrontando a estrutura aos juízos formulados, poder-se-á verificar a existência ou não da legitimidade do uso de algumas operações e pressupostos teóricos. A ausência de certos procedimentos comuns à literatura do fim do século XIX, em São Bernardo, leva muita vez o observador a eleger meios de análise anacrônicos, puramente morais ou ideológicos. E isso tende a sobrecarregar a crítica, exigindo dela posições muitas vezes exclusivamente éticas ou políticas, afastando-a do plano literário e estético, próprios da ficção. Pouco a pouco, sem perceber, o crítico, numa espécie de comprometimento ético-moral, responde mais ao seu tempo, a partir da interpretação, do que ao plano literário. Ou seja, é necessária a distinção, que não deixa de ser política, desses dois planos sem esquecermos de que também o pesquisador está sujeito a tais efeitos. Essa postura nos permitirá o estudo do fenômeno da leitura. Iser assim define esses dois momentos da apreensão de sentido e atribuição de significado ao texto: “(...) O primeiro fato (a estrutura intersubjetiva da produção de sentido) se refere à teoria do efeito dos textos, o segundo (o significado atribuído a um sentido), à teoria da recepção, que será cunhada mais por premissas sociológicas do que por premissas literárias." (ISER, 1999: p. 81)

Portanto, o romance será examinado em três níveis de análise: o nível estrutural da narrativa; o nível fenomenológico da leitura; e, por fim, o nível da recepção crítica. Apesar do esforço para que eles não se confundam, muitas vezes seremos obrigados a conjugá-los simultaneamente. Nesse sentido, tomaremos todos os cuidados necessários para que isso não ocorra sem clareza.

Como já foi dito, conformando-se a essas etapas de estudo, não desenvolveremos aqui a sequência lógica; a saber, a reconstituição histórica ou do panorama histórico da recepção em perspectiva cumulativa, abordando a crítica sobre São Bernardo surgida de 1934 até os dias atuais, para depois entrarmos nas análises. Essa sequência, aparentemente lógica, esconde o problema fundamental de que a análise na atualidade não pode dialogar senão com

${ }^{15}$ CANDIDO, Antonio. Formação da Literatura Brasileira (Momentos Decisivos) vol. 1. / 4. ${ }^{a}$ Edição. São Paulo: Martins Fonte S. A. (s.d.) (Cf. p. 32) 
ela mesma e no momento da enunciação crítica. E pelo fato de o parecer crítico surgido nos primeiros anos da publicação de São Bernardo ser desconhecido, sofreria profunda influência do juízo que se tem da obra na atualidade. Em outras palavras, essa sequência poderia sugerir que o momento presente seria o ponto culminante de ideias que se desenvolveram em evolução ascendente, em que o passado só teria importância na medida em que acenasse para o desenvolvimento futuro de quaisquer que sejam as hipóteses.

Pelo contrário, as hipóteses de uma determinada época são tão importantes quanto as de outras, anteriores ou posteriores; ainda que muitas vezes nada digam ao nosso tempo, tiveram a sua importância e podem circunscrever práticas esclarecedoras para a compreensão histórica de um evento isolado ainda desconhecido ou confuso. Como, por exemplo, explicar o motivo de que São Bernardo esteja marcado historicamente pela indefinição de sua convenção literária? Embora ele esteja inserido historicamente no que se convencionou chamar de Regionalismo ou $2^{a}$ fase do Modernismo, Neorrealismo etc., não há nenhum consenso sobre sua modernidade; isto é, tem-se falado, de modo geral, de um tipo de modernização que preservou elementos classicizantes da literatura; contudo, em que reside essa "modernização"? A maior parte das análises e interpretações baseia-se em critérios e categorias de leitura bem tradicionais. O que a crítica não deixou de fazer foi apontar as insuficiências destas últimas em alguma medida como falha do autor ou, como escreveu Osman Lins, "espécie de maestria às avessas".

Antes de tudo, portanto, a tese desenvolvida nesta pesquisa é a de que São Bernardo é um discurso metaliterário (Regina Zilberman). Os dois personagens principais, passando pelo mais apagado coadjuvante do romance, estão representados como concepções literárias ou ideais literários, cujas ações explicitam-se em termos ideológicos. A própria organização do romance indica duas grandes unidades de sentido: a primeira parte, antes de ser épica, tem enorme semelhança com certas fórmulas romanescas em que um "herói” é reconhecido, pouco a pouco, até revelar-se no ambiente construído como aquele que sofreu ali algum dano ou uma afronta no passado, do qual é redimido por um feito extraordinário e reconhecido. A outra metade assemelha-se com o romance psicológico, realista e naturalista, cuja caracterização principal seria a de retratar um drama de consciência burguesa ante uma culpa ou a busca de sentido da vida humana. Uma metade e outra estão ligadas àqueles que funcionam como nú- 
cleo do conflito: a primeira metade do romance conta a história da ascensão de Paulo Honório, sua revelação; a outra metade, o drama de Madalena.

Eis então o motivo para que a primeira etapa a ser realizada seja a análise a que nos propomos, sem trazer para essa fase de pesquisa as primeiras manifestações críticas: elas não dialogam com este trabalho em termos de hipótese e pressupostos no sentido de análise de sua forma e estrutura, mas sim o que há de mais atual e abrangente em termos gerais sobre o segundo romance de Graciliano Ramos. Somente após essa etapa e sua finalização passaremos a expor o que sucedeu à obra nos anos de 1934 a 1938, visto que, além de nos ser completamente estranha a manifestação aí ocorrida, a consciência atual da obra São Bernardo que temos é tributária dos anos de 1950 em diante, com os quais, desde o início, esta pesquisa dialoga em todas as suas etapas de formulação e hipóteses. 


\section{Objetivo}

(...) na tessitura dialogizada do discurso romanesco, o reconhecimento de uma linguagem realiza-se por outra linguagem, o reconhecimento de uma concepção de mundo é feito por outra concepção de mundo. E é essa, segundo Bakhtin, a tarefa do romance: o desmascaramento das linguagens sociais e das ideologias. ${ }^{16}$

Pode-se dizer que o debate sobre a função do romance na sociedade, dentro e fora de São Bernardo, está sempre aberto, independentemente do tempo e do lugar, a menos que houvesse uma superação do gênero, tal qual houve com o gênero trágico no teatro. E há em São Bernardo uma espécie de "debate sobre o ideal romanesco ou a legitimidade dele" de modo indireto; ideal que se oblitera no cotidiano em forma de noção simples ou banal, mas que Graciliano soube reproduzir, na narrativa, através de personagem-autor, leitores, críticos de valores aceitos ou negados estética e ideologicamente, diretores, professor, jornalistas etc.

A propósito, até mesmo a fórmula discursiva usada para assediar Madalena a fím de aproximá-la dos limites da fazenda, como professora da escola em São Bernardo, é uma concepção literária calcada nos limites da poesia idílica, idealista e romântica: vemos isso claramente nas palavras que Gondim vai usar para tentar convencê-la de ir trabalhar na fazenda: "Arrumo-lhe a paisagem, a poesia do campo, a simplicidade das almas. E se ela não se convencer, sapeco-lhe um bocado de patriotismo por cima.” (p. 86). Gondim aqui não somente se caracteriza pelo seu próprio discurso como, por contraste de sua concepção em relação à reação de Madalena, define-a segundo um ideal convencional e ingênuo. Efetivamente ele não a convence a deixar a escola em Viçosa, mas será segundo o padrão ideal manifestado por Gondim o motivo que a levará aceitar o casamento com Paulo Honório, confirmando que ele a conhecia bem:

- Parece que nos entendemos. Sempre desejei viver no campo, acordar cedo, cuidar de um jardim. $\underline{\text { Há }}$ lá um jardim, não? ${ }^{17}$ Mas porque não espera mais um pouco? Para ser franca, não sinto amor.

- Ora essa! Se a senhora dissesse que sentia isso, eu não acreditava. (p. 93)

No jogo da sedução lançada por Gondim, assim como o êxito alcançado indiretamente, explicitam-se concepções literárias cuja base ideal concretiza-se nas decisões

\footnotetext{
${ }^{16}$ MARINHO, Maria Celina Novaes. A Imagem da Linguagem na Obra de Graciliano Ramos: Uma Análise da Heterogeneidade Discursiva nos Romances Angústia e Vidas Secas / São Paulo: Humanitas / FFLCH/ USP, 2000. (Cf. p. 40)

${ }^{17}$ Grifos meus; doravante o padrão utilizado neste trabalho. A pergunta se refere à tentativa de Gondim convencê-la a trabalhar para Paulo Honório.
} 
tomadas ou ações. Madalena confunde Paulo Honório com Gondim, acreditando ser ele o autor das ideias formuladas pelo jornalista a fim de convencê-la a ser a professora da fazenda São Bernardo. Na verdade tanto ela não sabe quem é Paulo Honório como o próprio Paulo Honório a desconhece: o último termo a que ela se refere, "amor", complementa a totalidade do gênero literário de seu ideal de vida. E o motivo de acreditar que havia um ponto em comum entre eles, "nos entendemos", é originado pelo assédio ideológico lançado por Gondim, do qual Paulo Honório não tem a menor ideia.

Isto nos permite dizer que esses personagens não só se apresentam como modalidades narratológicas e dramáticas; elas teatralizam os efeitos de suas concepções no desfecho das decisões, ações tomadas, atos de pensamentos e juízos formulados em certas ocasiões. O juízo, as palavras de Gondim, entra em choque com o de Madalena e a desmascara como "ingênua", idealista; enquanto Gondim se revela, em relação ao ideal explicitado nas decisões de Madalena, não só conhecedor do pensamento dela como sabedor da verdadeira condição da fazenda São Bernardo e de seus moradores. Ou seja: Gondim seria idealmente um tipo de escritor, farsante, falsificador consciente da ingenuidade de certos leitores.

Não há dúvidas de que Graciliano construiu esse romance metalinguisticamente a fim de formular sua crítica a esses aspectos da literatura. Embora ela só possa ser formulada como síntese do leitor, o convencionalismo das ideias implícitas nos termos e palavras do diálogo não nos deixa dúvida alguma de que não só se trata de fórmulas literárias como são coordenadas oferecidas ao próprio leitor. E o modo de produzir a polêmica, o conflito das ideias aí apresentadas, é duma perspicácia incomum, duma maestria própria dos grandes romancistas. E que Bakhtin explora e analisa da seguinte forma: “(...) o autor inclui no seu plano o discurso do outro voltado para suas próprias intenções. (...)” Isto é, sem interferir de forma direta através do narrador, por exemplo, com fim de ironizar ou de dar qualquer outro tipo de significação alheia ao discurso proferido. Continua Bakhtin, “Após penetrar nas palavras do outro e nela se instalar, a ideia do autor não entra em choque com a ideia do outro, mas a acompanha no sentido que esta assume, fazendo apenas esse sentido tornar-se convencional." 18

A neutralidade de Graciliano se apresenta, assim, através da construção de um narrador incapaz de avaliar, comentar, assumir uma posição particular e consciente em relação

\footnotetext{
${ }^{18}$ BAKHTIN, M. M. Problemas da Poética de Dostoiévski / trad. Paulo Bezerra; Rio de Janeiro: Forense Universitária, 1997. (Cf. pp. 193 e 194)
} 
aos discursos dos outros. Mas o verdadeiro autor sempre se deixa transparecer na medida em que põe na boca de seu narrador ou de seus personagens "ideias" que se contrapõem às suas concepções formais ou estilísticas. Elas se revelam diametralmente opostas às suas concepções: é consenso geral que Graciliano, pela forma de construir sua obra, se opõe às características literárias implicadas nas palavras tanto de Gondim como de Madalena. Os aspectos da paisagem, as características ríspidas, secas, nada melodiosas de sua escrita e de suas criaturas fictícias nada têm a ver com o padrão literário aludido acima:

\begin{abstract}
Neste sentido, todo enunciado tem uma espécie de autor, que no próprio enunciado escutamos como seu criador. Podemos não saber absolutamente nada sobre o autor real, como ele existe fora do enunciado. As formas dessa autoria real podem ser muito diversas. (...) e apesar de tudo, sentimos nela uma vontade criativa única (...) (BAKTHIN, 1997: p. 184)
\end{abstract}

Assim, procuraremos dar resposta ao que parece perguntar-se o próprio protagonista do romance no final do capítulo 2, como se a pergunta fosse sugerida pelo leitor, ainda que surgida na consciência do protagonista ou mesmo da boca de um dos coadjuvantes: "Então para que escreve?" Essa resposta, surgida do impasse diante da escrita, corresponderá à interpretação final do trabalho e deverá partir da constelação de elementos que envolvem o narrador-personagem e problematizam a questão em que está ele envolvido dialogicamente.

Para que tal tarefa se possa realizar, utilizaremos a teoria de análise do discurso em parceria com outros modelos de abordagem, principalmente lançaremos mão da estética da recepção e da teoria do efeito estético, a fim de evitar uma visão unilateral e poder, de modo integrativo, colaborar com outras perspectivas de análise crítica. Acreditamos que há níveis diferentes de análise; e as "divergências" ocorrem, muitas vezes, pela ocupação de posições contrárias ante o objeto de pesquisa, visto deste ou daquele ângulo, o que não as impedem de convergir em determinados pontos (evidentemente não se deve forçar fronteiras e limites de teorias a fim de que extrapolem os seus próprios limites de alcance e nem se conduza a operação ao ecletismo fácil e risonho de toda explicação: nossa proposta, aqui, é a de não deixar de recorrer, se necessário, a ferramentas adequadas em certas ocasiões impostas circunstancialmente pelo romance, ainda que se tenha adotado um procedimento $x$ ). Pois nem sempre um modelo, qualquer que seja, é capaz de explicar tudo; por exemplo, pela análise marxista, não seria possível explicar certo número de relações manifestadas no romance, já que escapam alguns valores cujas noções teóricas do modelo não podem dar conta senão pela força, ou simplesmente suprimindo-os das considerações como "detalhe" isolado. 
Em São Bernardo isso não se dá de modo diferente: não se pode chamar "vingança" de "livre concorrência"; de "pacto", "contrato de trabalho"; de "matrimônio em comunhão de bens", "pacto familiar e de sangue"; "superstição", de "mentalidade utilitarista" etc. Ou seja, nem sempre as noções analíticas marxistas são adequadas a determinadas circunstâncias. Ainda mais quando se trata de um escritor como Graciliano Ramos, cuja prática artística parece agregar variadas hipóteses de realização.

Acreditamos que este seja um dos mais importantes romances da geração de 30, senão o principal, cuja proposta de debate vai além do que foi observado pela crítica até hoje. Sua denúncia não se reduz à formação e derrocada da propriedade rural e da constituição do perfil do proprietário sertanejo, já bem delineado e esclarecido. É também denúncia das linguagens e das ideologias que se fundamentam enquanto veículo dessa denúncia na forma de literatura. Merece, por isso, um estudo atualizado neste sentido. 


\title{
3. Recorte teórico e metodologia
}

\begin{abstract}
A interpretação de um elemento da obra é diferente segundo a personalidade do crítico, suas posições ideológicas, segundo a época. Para ser interpretado [tal elemento] é incluído num sistema que não é o da obra, mas o do crítico. ${ }^{19}$
\end{abstract}

Nunca, em qualquer circunstância de pesquisa científica em Literatura, deve-se ignorar o fato de que o objeto de pesquisa só é um objeto autônomo aparentemente. Graças a atualizações subjetivas, na diversidade de leituras produzidas por uma recepção crítica perene, é que obtém status de obra. Assim sendo, o "elemento subjetivo" é indelével no processo de produção de sentido e significado. Como, porém, atingir "objetividade" analítica se a subjetividade é imperativa no processo?

Ocorre que em certos modelos de análise o aspecto subjetivo da observação acoberta-se de um aparente véu de imparcialidade, sugerido pela elaboração de ponto de vista através da colaboração de propostas divergentes, dissolvendo assim qualquer suspeita de haver uma visão unilateral e inflexível. Já em outros casos, esse tecido fino deixa transparecer certo excesso de subjetividade, conformado a certos procedimentos de análise literária que se manifestam pela intolerância em face de outras perspectivas prováveis. É nesse segundo sentido que a subjetividade perturba mais: embora do primeiro aspecto acarrete-se a simulação de cooperação, mantendo a unilateralidade (o que pode obscurecer modelos e noções forçosamente a fim de alcançar resultados que não lhes seriam próprios); do segundo caso é impossível contornar a parcialidade, porque não se digna a compreender minimamente a pluralidade de perspectivas oferecidas por um texto; essa compreensão de pluralidade, a nosso ver, não só enobrece a perspectiva adotada como a legitima, no sentido de que, ao se ter ocupado das hipóteses concorrentes, lhes garante o direito de existência, autonomia e certa publicidade que mantêm sua autenticidade, sua participação no debate segundo seus verdadeiros pressupostos e limites de alcance.

Isso significa que, em qualquer circunstância, o crítico literário jamais deve perder de vista que, num grau de abstração superior, ele próprio faz parte do "objeto investigado" (segundo o consenso de que a subjetividade é indelével): ao fazer a leitura prévia do material de trabalho, não só se comporta como observador, mas também leitor minimamente

\footnotetext{
${ }^{19}$ TODOROV, Tzvetan. "As Categorias da Narrativa Literária” In: Análise Estrutural da Narrativa - Seleção de Ensaios da revista Communications: Intr. Milton José Pinto; Rio de Janeiro: Ed. Vozes LTDA, 1973. (Cf. p. 210)
} 
interessado do processo e de seu próprio tempo. E, participando da construção de significado de uma obra, firmando todos os contratos que o ato de leitura lhe impõe, mobilizando sua concepção do mundo, de universo moral ou ideológico, ainda que disso não tome consciência, é levado a dissimular os "atos intencionais" que "animam" o texto:

Em face do texto, surgem no nosso espírito certos estados de prazer, tristeza, constatação, serenidade, reprovação, simples interêsse. Estas impressões são preliminares importantes; o crítico tem de experimentá-las e deve manifestá-las, pois elas representam a dose necessária de arbítrio, que define a sua visão pessoal. (CANDIDO, (s.d): p. 32)

É muito apropriado o parecer de Candido, de outro modo não haveria crítica. Entretanto, acrescentamos numa segunda abordagem certa dose de ceticismo a toda confiança atribuída ao texto (incluindo-nos a nós mesmos no processo), sem o que não se poderiam mobilizar os juízos de valor surgidos na primeira leitura e processá-los na análise da segunda objetivamente: "Só o horizonte da segunda leitura pode converter a primeira leitura, quase pragmática e causadora de ilusão, em uma leitura captadora da ficção" (STIERLE, 1979: p. 159). Obtemos com um primeiro contato de leitura um saber mínimo sobre o texto, não sendo mais "ingênuos" ou suscetíveis à indução noutro instante.

Dois momentos bem distintos na operação. Toda reflexão mobilizada anteriormente pode ser confrontada agora, ser posta em dúvida, portanto, investigada sua matriz fictícia causadora de ilusão; assim como, também, sua consequência na interpretação. Stierle define a primeira leitura realizada de um texto como "quase pragmática", em que o movimento centrífugo do texto nos absorveria pela rede causadora de ilusão; já a segunda leitura inverte o processo da primeira: “Ao contrário, o movimento centrípeto, o único que pode levar à ficcionalidade do texto, é pouco familiar, é difícil, metodicamente trabalhoso, e isso tanto mais quanto o próprio texto ficcional é o resultado de um trabalho ousado de constituição." (STIERLE, 1979: p. 156)

Resulta disto que a análise literária, seja de qual obra for, não prescinde da adoção do ponto de vista de que também "sou objeto de investigação", de que "estou em condição suspeita": sou uma variante na leitura e, num esforço ainda maior, uma generalização de leituras anteriores a mim. Ainda que nem sempre a origem do nosso modo de interpretar um elemento de uma obra ou toda uma constelação de elementos não possa ser vislumbrada, é possível inscrevê-la e apurá-la através de perspectivas contrárias, verificando o seu teor: 
Um exemplo instrutivo para elucidar esse processo é a grande controvérsia sobre Milton entre C. S. Lewis e F. F. Leavis. C. S. Lewis formulou o argumento decisivo da polêmica da seguinte maneira: 'It is not that he and I see different things when we look at Paradise Lost. He sees and hates the very same that I see and love.” (...) Como é possível que um processo de constituição, intersubjetivamente idêntico, de repente provoque tantas diferenças? Por que juízos se tornam subjetivos, se se baseiam em critérios aparentemente objetivos? Uma possível resposta seria que um texto literário contém instruções, verificáveis intersubjetivamente, para a produção de seu sentido. (...) Se as operações estimuladas pelo texto têm um caráter intersubjetivo, então se estabelece uma base de comparação que permite avaliar os juízos subjetivos. (ISER, 1996: vol. 1. pp. 59 e 60)

Assim, concordamos com a perspectiva adotada por Antonio Candido a respeito do primeiro contato com a obra, mas não podemos dizer o mesmo do ponto em que tocou em seguida na Formação; a saber, que, "ao contrário do que pressupõem os formalistas, a compreensão da obra não prescinde da consideração dos elementos 'não-literários'. O texto não os anula, ao transfigurá-los (...)" (CANDIDO, s.d.: p. 35). Discordemos; num primeiro contato com o texto, mobilizamos, para o entendimento, "elementos não-literários", isto é, "coisas do mundo" que balizam a compreensão, graças à experiência empírica com as coisas ou pelo saber intelectual sobre elas. Tal situação corresponde à performance de "um leitor comum”, válida preliminarmente. Mas, se ficássemos somente aí, correríamos o risco de ver na literatura apenas imagens do mundo, ali plasmadas ostensivamente em detrimento do que é propriamente elaboração literária.

Isto ocorre porque os "elementos não-literários", numa obra, são só uma primeira face de reconhecimento do sentido e ocupam uma faixa dos limites da compreensão calcada no terreno sociológico, naturalmente, que de modo algum encerra o campo literário. Os elementos não-literários, num texto,

(...) procuram, essencialmente, criar a ilusão de realidade. (...) são, em geral, efeitos apenas de reconhecimento do mundo tal qual o lê o senso comum, ou seja, descobrem-se no texto as imagens do mundo. Só por meio das relações metafóricas e metonímicas instaladas entre duas ou mais linhas isotópicas obtêm-se efeitos de novo saber sobre as coisas, e, em lugar de reconhecer imagens já vistas, aprende-se a ler [a obra] de outro modo. ${ }^{20}$

Tomemos como exemplo uma imagem de São Bernardo que surge, no final do primeiro capítulo, bastante sugestiva: "Na torre da igreja uma coruja piou. Estremeci, pensei em Madalena.” Essa imagem vai-se repetir em vários capítulos ainda, gerando uma isotopia, isto é, a reincidência dos topoi "torre de igreja", "pio de coruja" associados a "Madalena" e à

\footnotetext{
${ }^{20}$ BARROS, Diana Luz Pessoa de. Teoria do Discurso: Fundamentos Semióticos / São Paulo: Humanitas / FFLCH / USP, 2001. (Cf. p. 154)
} 
escrita do livro, provocando a reação de "estremecimento" do protagonista. Se a tomássemos apenas como "não-literária", nada haveríamos de vislumbrar, em termos de sentido, senão que há uma "torre de igreja" em que "pia uma coruja". Mais ainda, esse elemento da narrativa não divergiria em nada dos que encontramos em outras obras ou mesmo daquela que encontramos em Infância: seriam idênticas.

Buíque tinha a aparência de um corpo aleijado: o largo da Feira formava o tronco; a rua da Pedra e a rua da Palha serviam de pernas, uma quase estirada, a outra curva, dando um passo, galgando um monte; a rua da Cruz, onde ficava o cemitério velho, constituía o braço único, levantado; e a cabeça era a igreja, de torre fina, povoada de corujas. ${ }^{21}$

Consideremos como hipótese que esta seja a primeira imagem que presenciou o autor, portanto um elemento real e preexistente à literatura; que "piou de verdade". Ora, o mesmo já não pode ser dito da que se encontra em São Bernardo, muito menos ainda em São Bernardo. Mas, até aqui, estamos no terreno do puro formalismo, que não se bastaria em si próprio apenas pela identificação dessa imagem como "elemento literário". Com razão recusa Antonio Candido esse tipo de procedimento: isto não basta, porque, de fato, ainda lhe falta a dimensão da sua transposição, de Buíque às terras de São Bernardo, de "elemento nãoliterário" à representação de outra coisa, numa outra plataforma de realidade:

(...) Tudo que é ideológico possui um significado e remete a algo situado fora de si mesmo (...) toda imagem artístico-simbólica ocasionada por um objeto particular já é um produto ideológico. Convertese, assim, em signo o objeto físico, o qual, sem deixar de fazer parte da realidade material, passa a refletir e a refratar, numa certa medida, uma outra realidade. (...) O pão e o vinho, por exemplo, tornam-se símbolos religiosos no sacramento cristão da comunhão. Mas o produto de consumo enquanto tal não é, de maneira nenhuma, um signo. ${ }^{22}$

Para Bakhtin, as condições materiais de conversão dos “elementos não-literários" em representações simbólicas constituem o ponto de partida de toda investigação. Pois é esta a realidade material da existência que promove o surgimento do significado e que permite ao artista executar práticas de representação. O significado, assim, jamais pode ser extraído do objeto em si: para que ele se torne signo (só é signo o que tem significado), é imperativo que se desvincule de sua realidade primária e, em outra dimensão da existência, obtenha status de

\footnotetext{
${ }^{21}$ RAMOS, Graciliano. Infância / Rio de Janeiro; São Paulo: Ed. Record, 1995. (Cf. p. 45)

22 BAKHTIN, Mikhail (V. N. Volichínov) Marxismo e Filosofia da Linguagem: Problemas Fundamentais do Método Sociológico na Ciência da Linguagem / São Paulo: Ed. Hucitec, 1992. (Cf. pp 31e 32)
} 
signo. Essa dimensão, evidentemente, é o seio social, lugar de interação entre os indivíduos e onde os significados circulam nas trocas verbais.

O significado então surge da interação, antes de penetrar a consciência isolada do indivíduo ou das abstrações formais. Mas, ao serem transportados para o campo ficcional, esses signos, símbolos ou elementos não-literários, modificam seus status e ampliam a rede de hipóteses do sentido. Seria, por isso, injustificável buscar no indivíduo Graciliano Ramos a origem do significado, por exemplo, da "imagem da coruja", assim como verificá-la apenas em termos de uma "gramática narrativa", e, sobretudo, confundi-la com uma representação direta da natureza, o que a tornaria uma ave qualquer. Isto é, não devemos descartar "as hipóteses formalistas" nem "as sociológicas", devemos conjugá-las na medida do possível e de seus alcances, sem prejuízo de uma nem de outra, como se fosse válida apenas uma hipótese e um recorte apenas da região analisada, exatamente porque suas coordenadas se tornaram fictícias.

Há claramente nessa imagem ou nesse elemento literário, na cadeia isotópica do texto, ligações internas que realçam um sentido novo, diferente do significado primário; e é do seio social, entre a passagem de coruja, ave qualquer, para "ave de mau agouro", na literatura, o lugar em que ela se atualiza simbolicamente como ideologia e componente estético; nesse caso, de elemento da natureza a elemento simbólico religioso ou folclórico, em seguida, a "elemento literário". Introduzida no texto, vai ser trabalhada com outras tintas, próprias do artista, dependendo de sua concepção de arte e gênero, cuja tarefa de atualização do significado passa a ser do leitor. Só a partir desse procedimento é possível averiguar categorias, pressuposto e hipóteses interpretativas e suas relevâncias.

A trajetória realizada pelo exemplo acima impõe uma compreensão mínima de diversos campos de operação, sem redução de nenhum deles. Como pode ser visto, a partir do texto de Graciliano, que dá as coordenadas do sentido possível, buscou-se o significado de um elemento segundo a sua relevância e não segundo a adoção de um modelo de análise; o que levou em conta, como possibilidade de interpretação, hipóteses diversas, passando pela biografia do autor, pela sociologia e pelo formalismo, até o campo específico da rede literária da imagem.

Pensar todas essas possibilidades alarga nosso campo de possibilidades e de discussão, e só vem a enriquecer o debate crítico e validar-se em termos de flexibilização para apurar os elementos de modo mais condizente com as possibilidades materiais da prática do 
artista. A inflexibilidade, inclusive, é a razão para que tantas pesquisas acabem dando resultados repetitivos e monótonos, reduzindo a potencialidade significativa dos textos a interpretações, muitas vezes, à mercê da intenção, até erradas. Nossa proposta é fazer a análise crítica dessa obra através da semiótica, averiguando-lhe o desempenho através de outras perspectivas, sem detrimento de nenhuma delas ${ }^{23}$ - desde que não haja incongruências, evidentemente - ou pelo menos sem ocultá-las no processo de análise ou do programa de estudo; mesmo que seja para reconhecermo-nos limitados à compreensão delas, merecem ser mencionadas.

Acreditamos que, de certa maneira, o romancista lança mão de todos os recursos à sua disposição na produção artística, dinamizando-os simultaneamente. Não é razoável crer que de um único golpe se dê resposta a tal complexidade. Daí a necessidade de não começar a pesquisa de uma obra, como dizíamos inicialmente, considerando-a um objeto autônomo: "ser uma obra" é uma ideia acabada -, incluindo, aí, um leitor ideal e um sentido de certo modo particular -, assumida como universal, o que anula a própria potencialidade do texto de produtor histórico de sentido em todos os tempos: "Essas ideias que parecem ter autonomia e aparecem desvinculadas dos homens e das condições reais que as produziram é que formam a ideologia, entendida como ilusão, como inversão do real. É o que permite que o interesse particular seja tomado como interesse geral (...)" (MARINHO, 2000: p. 26).

Se o crítico não se posiciona ante o objeto de pesquisa, considerando-o em sua natureza primária e em condições potenciais de produção simbólica (que é a interação leitor/texto numa relação dialética), sem que se considere como parte dessas condições (o que é inerente à sua condição) e em certo ponto do campo de atuação situado, corre o risco de ser manipulado por algum tipo de ideal, seja ele totalitário ou democrático, em detrimento do "fazer científico", que é um lugar neutro ou livre de interesses alheios à operação. Isto é, considera-se aqui uma operação científica o momento do processo de investigação em que os juízos de valor literário pessoal ou de uma época são neutralizados em favor da compreensão dos fenômenos que implicam a produção simbólica do significado e das práticas de representação do autor historicamente. O texto literário, aqui, é considerado como

\footnotetext{
${ }^{23}$ (...) a análise narrativa procura utilizar o quadro geral (...) da teoria semiótica, buscando mostrar (...) a especificidade de cada texto, e não (...) uma fôrma, em que devam entrar obrigatoriamente os mais diversos discursos. (BARROS, 2001: p. 28)
} 
comunicação. E não poderia ser de outra forma, já que sua finalidade é comunicar seja o que for, e que não o poderia realizar sozinho.

Esse momento só passa a se distinguir do fazer científico - que não é puro nem mesmo em outras áreas das ciências, como a Biologia ou a Física (cujos pressupostos e hipóteses jamais deixaram de participar do mundo da cultura ou da política de um Estado ou nação), no que tange a interferências no processo histórico, cultural e político. O que não se deixará por fazer, inclusive, neste trabalho; contudo, em lugar próprio e adequado, segundo o princípio de que não podemos prescindir do mundo em que vivemos, do tempo e dos interesses ligados ao momento em que se enuncia o enunciado crítico. 


\section{Justificativa}

As pessoas que me lerem terão, pois, a bondade de traduzir isto em linguagem literária, se quiserem. Se não quiserem, pouco se perde. Não pretendo bancar escritor. (p. 11)

Paulo Honório

Destacando-se como um dos mais importantes romances da década de 30, São Bernardo de Graciliano Ramos é objeto de inúmeros ensaios e "capítulos", encontrados na vasta bibliografia que põe ênfase na trajetória e na obra geral do autor. 1934 é a data da primeira edição, seguida, quatro anos depois, de uma segunda, quando Graciliano Ramos passa da editora Ariel para a José Olímpio.

A terceira edição veio quase dez anos depois, em 1947; edição, inclusive, isolada nessa década. Pouco depois, em abril de 1949, o jornal $O$ Globo dá notícias de que São Bernardo seria a próxima novela radiofônica de Amaral Gurgel. Em 1953, o livro estava na quinta edição, enquanto Caetés e Vidas Secas, na terceira, e Angústia, na quinta igualmente. Contudo, a década de 1960 viria duplicar os números, o que levou São Bernardo a perseguir a mesma trilha de Vidas Secas, que era “(...) certamente a mais bem-sucedida obra de seu autor: 200.000 exemplares vendidos no Brasil (...) até 1970, em comparação com os 95.000 exemplares vendidos no Brasil, e outro tanto no exterior, de São Bernardo, seu best-seller seguinte. $" 24$

Não tratemos das traduções aqui. Contudo vale dizer que, em nossas leituras da recepção na década de 1930, ficamos sabendo que São Bernardo tivera sua primeira versão em língua estrangeira entre 1935 e 36, na Argentina, com o título de "Feudo Bárbaro". Não sabemos o porquê de que nunca se tenha falado desse detalhe. O certo é que, em uma das crônicas, ao referir-se a essa tradução, fala-se em uma possível polêmica em torno da publicação de São Bernardo na Argentina.

\footnotetext{
${ }^{24}$ HALLEWELL, Laurence. O Livro no Brasil (Sua História) / São Paulo: T. A. Queiroz, Editor / Editora da Universidade de São Paulo, 1985. (Cf. p. 358)
} 


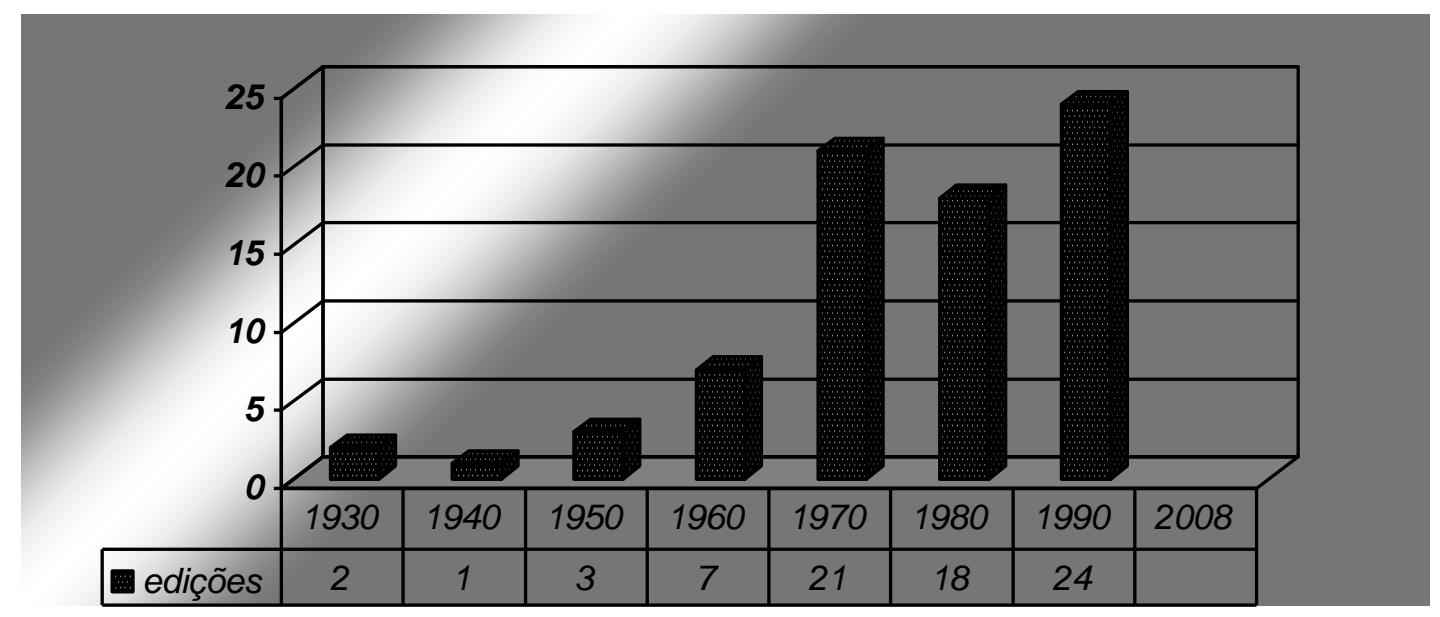

Figura 1: gráfico de publicações em décadas de São Bernardo

Em 1972, o diretor Leon Hirszman leva São Bernardo às telas; década de muitas publicações, 21 ao todo, muito provavelmente influenciadas pela produção cinematográfica e pela entrada do romance na lista dos livros de exame vestibular. Em 1983 Vidas Secas chegou à $51^{\text {a }}$ edição; em 1984, data comemorativa dos 50 anos de São Bernardo, vem a $42^{\mathrm{a}}$ edição, enquanto Caetés chega à $20^{\mathrm{a}}$ e Angústia, à $29^{\mathrm{a}} .{ }^{25}$

Apesar de São Bernardo ombrear a disputa de popularidade com Vidas Secas, são poucos os estudos que se limitam a abordá-lo exclusivamente. Entre os mais percorridos nas buscas e pesquisas, encontram-se "O Mundo à Revelia", de João Luiz Lafetá, e o capítulo "Ficção e Confissão", em Ficção e Confissão: Ensaios Sobre Graciliano Ramos, de Antonio Candido (apesar de neste trabalho abordar-se todo o percurso literário do autor como finalidade última). Evidentemente, há estudos exclusivos, como São Bernardo e os Processos de Comunicação, de Regina Zilberman, (cuja análise fundamenta-se na estrutura da obra; recorte também de Lafetá, embora este tenha limitado bastante os processos analíticos lançados pelos formalistas, mesclando-os com outros e dilatando a análise sociológica/marxista); também na década de 1970, um excelente estudo, apesar de muito pouco conhecido, vem à tona: Uma Leitura de São Bernardo: A Exortação Litótica, de Paschoa Baldassari Guardiano. Mais recentemente, no Livro Agreste, de Abel Barros Baptista, 2005, encontramos um ótimo estudo, "O Livro Agreste (1)", (apesar de também não se ter dedicado exclusivamente a São Bernardo, tratando-se de um relatório de publicação do curso de Literatura Brasileira ministrado na Universidade Nova de Lisboa); este texto foi melhorado, já que a primeira versão desse capí-

\footnotetext{
${ }^{25}$ Segundo a pesquisa do site www.graciliano.com.br/bibliogr.html, em 2003, Vidas Secas chegou à $92^{\mathrm{a}}$ edição, enquanto São Bernardo alcançou a $76^{\mathrm{a}}$, e Angústia, que a crítica acreditava ser o best seller do autor, à $56^{\mathrm{a}}$ edição. Contudo as publicações não param: em 2008, São Bernardo atingiu a $86^{\mathrm{a}}$ edição, mantendo uma distância de 24 edições à frente de Angústia, que chegara à $62^{\mathrm{a}}$ ed. em 2007, (distância que poderia ser calculada como uma década, levando em consideração os anos de 1990, por exemplo); enquanto Vidas Secas atingiu, no ano de 2008, a $105^{\mathrm{a}}$ ed.; sendo que Caetés aponta para $31{ }^{\mathrm{a}}{ }^{\mathrm{e}}$ ed., ainda em 2006.
} 
tulo fora escrita em 1992 e publicada na revista Colóquio Letras, de Lisboa, com o título de "Na Torre da Igreja uma Coruja Piou: Autor ficcional e Ficção do livro em 'São Bernardo"”.

Além desses trabalhos, uns diretamente e outros mais ou menos relativos ao segundo romance de Graciliano, há ensaios que merecem destaque, como os de Nelly Novaes Coelho, "Solidão e Luta em Graciliano Ramos"; "Dettera: Ilusão e Verdade - Sobre a (im)propriedade em alguns narradores de Graciliano Ramos", de Valentim Facioli; e "A Reificação de Paulo Honório”, In: Por Que Literatura?, de Luiz Costa Lima, escrito entre 1965 e 1966, que nos fornece um excelente estudo do drama do protagonista com a aplicação da noção marxista de reificação ${ }^{26}$. Finalmente, um dos mais bem-sucedidos ensaios, considerados aqui, foi "Homenagem a Graciliano", de Osman Lins, publicado em jornal por volta de 1972. Mais recentemente, em 2006, foi defendida na Universidade de São Paulo, no programa de Pós-Graduação em Literatura Brasileira, a dissertação de mestrado História e Alegoria em São Bernardo de Graciliano Ramos, de Edmundo Juarez Filho, em que se parte da hipótese de o autor ter construído o romance como "alegoria" da derrocada das oligarquias constituídas na República Velha, propondo-se que a Revolução de 30 seria o solo histórico do romance.

Chama atenção, porém, o fato de que poucos se alçaram a um projeto de estudo mais detido do segundo romance do autor: multiplicam-se enormemente os estudos ou sobre Graciliano Ramos ou sua obra na totalidade ${ }^{27}$; tal aspecto deu como produto, no conjunto dessas pesquisas, apenas capítulos muito generalizantes sobre alguns romances, como os referentes a São Bernardo; e pouca avaliação do pormenor. Se, por um lado, essa vasta bibliografia trouxe enorme notabilidade ao escritor, em termos de crítica biográfica e popularização de seu nome, por outro reduziu a "poucas páginas" algumas obras. Esse tem sido o viés mais percorrido pela crítica ainda agora. Tal proposta de pesquisa e estudo desembocou em muita redundância:

\footnotetext{
${ }^{26}$ Luiz Costa Lima, numa entrevista realizada em 23/03/2010 no Rio de Janeiro, concedida a Mario Tommaso Pugliese (editor da revista literária Opiniães, fundada neste mesmo ano pelos estudantes de Pós-Graduação do Departamento de Letras Clássicas e Vernáculas da Universidade de São Paulo), Laura Pena, Mônica Gama e Edilson Dias de Moura, revelou-nos que já no começo da década de 1970 havia reformulado sua crítica a respeito de São Bernardo com base na aplicação da noção teórica da reificação. Segundo ele, a categoria leva ao prejuízo analítico de se reificar não só todo o romance como a ela própria. Embora haja essa divergência do modo de pensar do autor hoje, manteremos as suas ideias iniciais como dado do momento histórico em que escreveu sua crítica, como sendo apropriação de outras leituras. Preserva, portanto, seu texto como dado de um período, embora divirja de suas concepções atuais.

${ }^{27}$ Eunaldo Verdi, em seu trabalho Graciliano Ramos e A Crítica Literária publicado em 1989 pela editora da UFSC, aponta essa peculiaridade da crítica, em geral, em abordagem da obra do romancista alagoano. Em quadros estatísticos, Verdi revela-nos, por exemplo, um universo de 177 estudos abordados, até a data de finalização de sua pesquisa, saltando aos olhos os números de 63 trabalhos dedicados à abordagem da obra em conjunto e 30 sobre a vida do autor, distribuindo-se o restante em estudos cuja mescla de análise biográfica reduz ainda bastante as abordagens específicas.
} 
pouco se vislumbra num grande emaranhado de paráfrases. Mas não se pode atribuir tal redundância a nenhuma das obras do autor de Vidas Secas: pelo contrário, há em cada parágrafo de seus trabalhos, oficina de um primoroso artesão, relações e construções minuciosas, movimentos correlatos de períodos propositalmente ali colocados, inclusive talhados e pensados em suas repercussões dentro e fora da ficção; há ainda no assoalho de seu atelier vestígio de arestas ali aparadas deste ou daquele gesto. Contudo, tem-se reduzido São Bernardo à "história do proprietário rural assassino e da heroína socialista/humanista que se suicida desesperadamente em decorrência do ciúme do marido" ${ }^{28}$.

Indo muito além, essa obra contém a virtude de ser romance que nega os ideais literários unilaterais totalizantes, ameaçando pôr às vistas seus pilares de sustentação e superálos; sobretudo, discutindo-os em todos os níveis, desde o mais simples fenômeno produzido pelas tendências até o mais meticuloso controle exercido pelo estatuto ideológico que lhe forjou forma e significado. É por esse motivo que uma das precipitações capitais da crítica foi ter, de chofre, dado a autoria de São Bernardo a Paulo Honório. Isto o reduz a um único nível de análise e interpretação, levando a uma via que põe fora de sua estrutura boa parte do que constitui a inovação realizada pelo romancista; muito embora alguns críticos tenham percebido, sem meios de análise, ser absurdo um coronel semialfabetizado escrever um romance de tal envergadura, ficaram a meio-caminho do que talvez fosse a crítica do romancista, em termos formais ou artísticos, de como se concebia o gênero àquela altura e sua produção. Partir da averiguação minuciosa da estrutura em que se erigiu o romance deve ser a meta de um trabalho que se preste a verificar a "produção de Graciliano Ramos", sem que se incorra na precipitação nem desconhecendo o que o autor mais prezava no ato de construção e de redação de um texto. Há, aliás, várias referências a essa característica de seu trabalho, como, por exemplo, em Memórias do Cárcere, o episódio em que Sérgio (Rafael Kamprad era seu nome verdadeiro), preso de origem russa, lendo São Bernardo em ritmo alucinante, perturba o escritor alagoano.

Afirmava-me não ser difícil percorrermos um texto, apreendendo a essência e largando o pormenor. Isso me desagradava. São as minúcias que me prendem, fixo-me nelas, utilizo insignificâncias na de-

\footnotetext{
28 “[Graciliano Ramos] (...) se ressentia, inegavelmente, da tendência predominantemente para uma visão intimista, quase psicanalítica, de Angústia, desejava que chegassem ao global do livro, às suas muitas intenções no campo social. Inversamente, desejava também que a análise de São Bernardo fosse menos sociológica, que vissem no romance, além de um estudo sobre a formação da propriedade ou o perfil de um proprietário rural, encontrassem nele o drama humano e seus liames. Em última instância, o que recusava era o estereótipo, a nossa queda para o unilateral." RAMOS, Ricardo. "Lembrança de Graciliano” In: GARBUGLIO, José Carlos; BOSI, Alfredo; e FACIOLI, Valentim (orgs.) Graciliano Ramos. São Paulo: Editora Ática S.A., 1987. (Cf. pp 18 e 19)
} 
morada construção das minhas histórias. Aquele entendimento rápido, afeito a saltos vertiginosos e complicadas viagens, contrastava com as minhas pequeninas habilidades que pezunhavam longas horas na redação de um período. Julguei Sérgio isento de emoção, e isto me aterrou. ${ }^{29}$

Lafetá, no seu ensaio, pela natureza mesma do gênero em que escreve, acaba levado pela mesma rapidez: ao expor seu aparato analítico, põe fora de seu escopo os detalhes, justificando-se, inclusive, "pela insignificância dos pormenores", privilegiando o que ele distingue como "tom do narrador":

O "sumário narrativo", explica-nos Norman Friedman, "é a exposição generalizada de uma série de eventos, abrangendo um certo período de tempo e uma variedade de locais"; a cena, por sua vez, implica a apresentação de detalhes concretos e específicos, dentro de uma estrutura bem determinada de tempo e lugar (...) Ora, neste terceiro capítulo o tempo é vasto e os eventos são muitos. O fato é que Paulo Honório não se detém neles, narra-os por cima e depressa. (...) A título de exemplo conta o caso do Dr. Sampaio. Nem aí, entretanto, se pode falar de cena: apesar dos detalhes que surgem, o que importa é o tom do narrador (...) [assim] então, temos o sumário narrativo. ${ }^{30}$

Repete em outras palavras o que Antonio Candido diz em Ficção e Confissão: "Não há em São Bernardo uma única descrição, no sentido romântico e naturalista (...)”31. Lafetá diverge levemente de Antonio Candido quando denomina "tom do narrador" como "sumário narrativo"; forçando a noção de Friedman a dar conta de um tipo de recurso narrativo que não se previa nem se observava em romances realistas ou naturalistas: “o tom do narrador" não tem caráter descritivo. Não pode cumprir tal função. É efeito que advém do que Dino Preti caracteriza como signos prosódicos.

(...) há pouquíssimos recurso para representar, na língua escrita, os signos prosódicos, decorrentes dos chamados elementos supra-segmentais. Trata-se de signos marginais à dupla articulação da linguagem, com significante e significados próprios e com valor essencialmente expressivos na mensagem. Compreenderiam o que Sapir, com muita propriedade, chamou de "dinâmica vocal", ou seja, o ritmo, a entoação, a fluência relativa à fala. ${ }^{32}$

\footnotetext{
${ }^{29}$ RAMOS, Graciliano. Memórias do Cárcere (I), prefácio: Nelson Wernek Sodré. (Mestres da Literatura Contemporânea) Rio de Janeiro/São Paulo: Editora Record/Altaya, (s. d.). (Cf. p. 230)

${ }^{30}$ LAFETÁ, João Luiz. "O Mundo à Revelia" In: A Dimensão da Noite e Outros Ensaios / São Paulo: Duas Cidades; Ed. 34, 2004. (Cf. pp. 76 e 77)

${ }^{31}$ CANDIDO, Antonio. Ficção e Confissão: Ensaios Sobre Graciliano Ramos / Rio de Janeiro: Ed. 34, 1992. (Cf. p. 32) Ao especificar "descrição" como "romântica e naturalista", o crítico revela que sua perspectiva de análise em São Bernardo. Isto é, sua observação do romance se faz contra um pano de fundo caracterizado pelo padrão artístico próprio do final do século XIX e princípios do século XX.

32 PRETI, Dino. Sociolinguística: Os Níveis de Fala, Um Estudo Sociolinguístico do Diálogo na Literatura Brasileira / São Paulo: Editora Nacional, 1974. (Cf. pp. 46 e 47)
} 
O "tom do narrador", efeito alcançado por "expressões situacionais" de fala (por exemplo, “É o diabo!”, “Ora vejam.”, “Sei lá”, “É verdade.”), não pode suportar tal categorização descritiva (como foi visto, tais elementos na narrativa teriam função propriamente de introdução das modalidades discursivas). A adoção dessa categoria de análise levou ao abandono de detalhes (próprios de cenas) e mostra que a perspectiva e pressupostos não se adaptam ao processo composicional da narrativa. Atentando-se a tais detalhes, percebemos que a forma de composição cenográfica é outra, diferente, revelando outras vias de significação e de prática de representação, rupturas com um sistema tal de valores, inovações abandonadas ao se privilegiar uma perspectiva de análise, como a de Friedman, ligada ao século XIX, ou mesmo àquelas em que essa categoria acarreta um tipo de narrador, em forma de autor fictício, só possível se escrevesse.

Tanto Candido como Lafetá sabiam bem que as noções de que lançavam mão aplicavam-se não só a um estilo de romance como caracterizavam a era moderna (do surgimento do Romantismo, passando pelo Realismo até o Pós-naturalismo/Regionalismo do começo do século XX); assim como, também, que o período de 30 dividiu-se entre o projeto estético vanguardista (os anos de 1920), marcado pela rejeição dos valores do passado, em termos formais, e o projeto ideológico (decênio de 30), marcado por um profundo mergulho da análise do presente e pela descrença na modernização como forma de solução para o estado de atraso do país. Nessa linha, Lafetá demonstra, com rápida análise do romance Mundos Mortos, de Octávio de Faria, a aplicação das noções de Friedman e como elas caracterizavam o romance produzido no passado.

\footnotetext{
O sumário narrativo e a onisciência são dois traços marcantes de todo romance em questão. Anotemos aqui, com Norman Friedman, que "podemos arriscar a generalização ampla de que a ficção moderna é caracterizada pela sua ênfase na cena / em inglês: showing/ (na mente ou nas palavras e na ação), enquanto a ficção convencional é caracterizada pela ênfase na narração [o sumário narrativo] (...) $)^{33}$
}

Ao dizer, em "O Mundo à Revelia", que o importante é o "tom do narrador", a perspectiva privilegiada torna-se exatamente essa tomada generalizante do sumário narrativo, que, aplicada à análise de alguns autores como Flaubert, Balzac, Eça de Queiroz, Machado de Assis etc. - em geral romancistas do século anterior ou os que ainda se adequavam ao romance realista e naturalista -, poderia levar à obtenção de algum êxito analítico, mas moldando-o a convenções literárias de uma época $x$. E se é a partir desse instrumental que o crítico vai de-

\footnotetext{
${ }^{33}$ LAFETÁ, João Luiz. 1930: A Crítica e o Modernismo / São Paulo: Duas Cidades; Ed. 34, 2000. (Cf. p. 238)
} 
monstrar o caráter passadista de todo Octávio de Faria - sua incompreensão do movimento modernista e a ênfase dada ao projeto ideológico do autor de Mundos Mortos -, isso não impede que o mesmo juízo de valor entre no jogo da análise de São Bernardo. Do que ele não se dá conta, supondo-se que esteja correto sobre Mundos Mortos, e não deduz (tanto o ensaio sobre São Bernardo como o livro 1930: a crítica e o Modernismo datam de 1973/74), é de haver no segundo romance de Graciliano outra concepção de estrutura, linguagem e romance. Certamente a versão dada pela história da literatura brasileira não o permitiria, assim como o período em que ele enuncia sua crítica, que não arriscasse a generalização:

(...) cessado, ou ao menos transformado, o contexto político em que João Luiz Lafetá escreveu seu estudo - e tendo defendido sua tese em maio de 1973, é preciso lembrar que essa tarefa foi executada durante os piores anos da ditadura instaurada de 1964 -, parte dele merece revisão. Afinal, o clima de polarização e a necessidade de combate "a todas as formas de pensamento reacionário [Antonio Candido]" justificam o procedimento rígido de combate ideológico que o texto assume, mas leva a certas simplificações $(\ldots)^{34}$

Tais simplificações, tanto na tese defendida como no ensaio, não deixam de transparecer em termos de contradição: "Não há, na entrada de S. Bernardo, nem uma palavra que sirva para localizá-lo [o leitor], nenhum painel descritivo [sumário narrativo] que lhe permita conhecer de antemão o mundo que vai agora visitar",35. O termo "painel" de entrada, descritivo, nos termos de sua análise, é exatamente o "sumário narrativo", o que garantia certa coesão temporal e espacial às narrativas, antecipava problemas, situava o leitor de certa forma num contexto geral narrativo.

Outrora, tempo e espaço, personagens e ação apresentavam-se forçosamente de forma coesa e bem delineada; um único exemplo, extraído do romance Dom Casmurro (1899), de Machado de Assis (18391908), demonstrará o fato:

'Vivo só, com um criado. A casa em que moro é própria; fi-la construir de propósito, levado de um desejo tão particular que me vexa imprimi-lo, mas vá lá. Um dia, há bastantes anos, lembrou-me reproduzir no Engenho Novo, a casa em que me criei na antiga Rua de Matacavalos, dando-lhe o mesmo aspecto e economia daquela outra, que desapareceu [...] é o mesmo prédio assobradado, três janelas de frente, varanda ao fundo, as mesmas alcovas e salas. [...] a pintura do teto e das paredes é mais ou menos igual, umas grinaldas de flores miúdas e grandes pássaros que as tomam nos bicos, de espaço a espaço. [...] O meu fim evidente era atar as duas pontas da vida, e restaurar na velhice a adolescência. Pois, senhor, não consegui recompor o que foi nem o que fui [...].'

\footnotetext{
${ }^{34}$ BUENO, Luís. Uma História do Romance de 30 / São Paulo: Edusp; Campinas: Ed. da Unicamp, 2006. (Cf, pp. 45 e 46). A observação de Luís Bueno tanto cabe a 1930, A Crítica e o Modernismo como a "O Mundo à Revelia", ambos trabalhos produzidos simultaneamente.

${ }^{35}$ Idem. (p. 74)
} 
Assim se afigura um relato ordenado que, embora ironicamente, apresenta um mundo genuinamente burguês (...) (ROSENTHAL, 1975: pp. 69 e 70)

Eis aí um "sumario narrativo" conforme a exposição teórica de Friedman. Lembrando que, desde o início, o critério adotado em nossa análise pretende averiguar os pressupostos, categorias de análise e hipóteses, não há erro nenhum na interpretação de Lafetá (do ponto de vista em que ela atualiza o texto, e que não deixa de nos orientar em certos aspectos). Mas são os pressupostos que falham, segundo categorias literárias epocais inaplicáveis ao segundo romance de Graciliano ou que não poderiam abranger a prática levada a cabo pelo autor alagoano. Lafetá não percebeu essa inaplicabilidade de imediato, contudo a admite, no final de seu ensaio, em nota de rodapé,

\begin{abstract}
A posição do narrador de S. Bernardo parece-me conferir ao livro uma dimensão nova, que o torna diferente do romance realista cuja estrutura Lukács descreveu em suas análises de Balzac, Stendhal e Mann. A subjetividade do ponto de vista provoca certas modificações essenciais na estrutura, das quais o monólogo interior é apenas uma. (...) A utilização de categorias diferentes das de Lukács poderia lançar uma outra luz sobre o livro. ${ }^{36}$
\end{abstract}

João Luiz Lafetá é um dos críticos mais honestos com que este trabalho dialoga. E como já se havia dito, ainda que divergindo dele, sua contribuição à tese que desenvolvemos aqui é das mais significativas. Evidentemente, a estrutura de São Bernardo nos dá a conhecer o seu conteúdo pela fragmentação e descontinuidade temporal (no âmbito da enunciação e, descritivamente, no enunciado). Percebe-se que há outro modo de apreender a realidade objetivada pelo narrador; realidade cujo nexo não se faz linearmente e "bem determinada" no espaço e no tempo, pondo em xeque modelos descritivos tradicionais. Até mesmo as categorias sociológicas "sujeito problemático/mundo problemático" de Lukács, assim como as de Walter Benjamin, são postas em dúvida, ao final, pelo crítico, exatamente por não abrangerem o universo total do romance; elas apenas dariam conta de fragmentos ali dispersos no enunciado, entre outros recortes de aspectos do mundo que, por fim, flutuam a partir de visões unívocas, o que problematiza a própria perspectiva tomada. Segundo essa concepção de romance é que Álvaro Lins vai sugerir a exclusão de capítulos inteiros em sua crítica, exatamente porque, para ele, "só com a morte de Madalena" haveria um motivo literário que justificasse o livro.

\footnotetext{
${ }^{36}$ Ibidem. (Pp. 101 e 102)
} 
Assim, somente uma abordagem multilateral é capaz de perceber esse todo composto de recortes. E é exatamente o que Lafetá vai tentar posteriormente:

Faço uma tentativa de ler a obra de Graciliano Ramos a partir de três diferentes suportes teóricos: George Lukács, Marthe Robert e Northrop Frye. O tripé assim formado parece (estou de acordo) bem estranho: marxista, psicanalista e poética de fundo aristotélico compõem uma mistura difícil de conciliar, facilitadora de todos os ecletismos. ${ }^{37}$

Apesar de a inquietação ter sido provocada pelo segundo romance de Graciliano, não é exatamente deste que vai ocupar-se: "Meu problema era saber em que medida o tradicional e o moderno (o neo-realismo e as conquistas literárias das vanguardas) se combinavam em Graciliano Ramos." 38 . Isto é, para que talvez essa nova postura crítica tivesse êxito, seria necessário desembaraçar-se de certas concepções históricas como a de que a análise biográfica levaria ao repertório material literário, sociológico e psíquico do autor; assim como desembaraçar-se da ideia de que Caetés e São Bernardo, por exemplo, “(...) pertencem àquela corrente de 'estudos sérios' deflagrada pela Revolução de 30"39.

Não era nenhuma novidade que o primeiro romance de Graciliano havia sido escrito oito anos antes de sua publicação; além do mais, a ausência de uma concepção de romance realista tradicional no segundo, como ele próprio percebeu, não se deixava reduzir a uma única perspectiva de análise e crítica. E isto porque

\footnotetext{
(...) do modo como se manifesta no século XX, a tendência ao fragmentário vincula-se ao declínio da importância da ideia de contínuo temporal (a história, o processo), em favor tanto de uma visão descontínua do tempo - o que na literatura, por exemplo, remete à destruição do enredo romanesco típico do século XIX - como do predomínio do elemento espacial (a estrutura). ${ }^{40}$
}

Além disso, diferente do romance ligado ao século XIX, ordenado e objetivo, “(...) O romance de hoje, adaptando-se às condições de nossa vida e ao caos moderno, questiona a nossa posição perante a realidade, e a maneira como se realiza o processo criador vem a ser mais importante do que a realidade visível (...)" (ROSENTHAL, 1975: p. 70) Daí Osman Lins, numa análise única na história crítica desse romance, dizer que

\footnotetext{
${ }^{37}$ LAFETÁ, João Luis. "Três Teorias do Romance: Alcance, Limitações e Complementaridade” In: A Dimensão da Noite e Outros Ensaios / São Paulo: Duas Cidades; Ed. 34, 2004. (Cf. p. 284)

${ }^{38}$ Idem.

${ }^{39}$ Ibidem.

${ }^{40}$ PONTIERI, Regina. "Roland Barthes e a Escrita Fragmentária" In: Língua e Literatura: ensaios; Revista do Departamento de Letras da Faculdade de Filosofia, Letras e Ciência Humanas da Universidade de São Paulo / S. Paulo, ano XIV, v. 17, 1989. (Cf. p. 86)
} 
Antônio Cândido (sic), em Ficção e Confissão, assinala haver em São Bernardo "um processo estilístico em maturidade, revelando o grande escritor na plenitude dos recursos" e salienta não haver na obra "uma única descrição, no sentido romântico e naturalista". Não estuda, entretanto, o modo ou modos como Graciliano Ramos soluciona o problema. ${ }^{41}$

Osman Lins tem razão. Candido diz no terceiro parágrafo de sua análise que o livro é "despido de recursos", depois afirma que ele "revela o grande escritor na plenitude dos recursos”. Daí partindo é que Osman Lins vai procurar no texto esses recursos; e não só vai demonstrar que o primeiro capítulo de São Bernardo é a construção da "plataforma física", em termos de cenário e ambiente em que vai se desenrolar o drama, assim como assinala no processo de construção do capítulo o "esmagamento do narrador ficcional pelo verdadeiro narrador" (curiosamente, o mesmo efeito que a narrativa de Ulisses realiza sobre o leitor).

Esse "narrador verdadeiro", segundo Osman Lins, é o responsável pelo efeito da aparente "ausência de recursos". Como, por exemplo, a ausência de apresentação de personagens de quais nada se sabe e que só vamos compreender melhor quando estiverem integrados à história. Ora, o fato é que, por exemplo, quando Paulo Honório fala do Gondim, numa microscópica fração temporal, descreve-se espantosamente não só coadjuvante como tudo que vai ser ligado a ele:

Este, sempre que entregava a redação ao Arquimedes, "trancava a gaveta onde guarda os níqueis e as pratas". A alusão, aparentemente casual e ligada a um simples comparsa, acha-se na verdade carregada de sentido: insinua, ao mesmo tempo, a precária situação financeira do tipógrafo e ainda a do jornal dirigido por Azevedo Gondim, onde só há níqueis e pratas guardados numa gaveta. (Note-se, ainda, sinal flagrante da aversão do mestre alagoano à redundância, que só então - e por dedução vamos saber em que jornal - há também a "esfomeada Gazeta" - onde trabalha Arquimedes. ${ }^{42}$

Osman Lins, demonstrando uma percepção aguda do modo como se caracterizam os personagens nesse primeiro capítulo, apanha flagrantemente o que Erwin Theodor Rosenthal apresenta como experiência sensorial produzida pela modernização, própria do século XX, reproduzida pelos autores:

Outrora descrevia-se uma paisagem, contemplando-a, por assim dizer, da janela de uma carruagem que seguia tranqüilamente seu caminho, permitindo que a sensibilidade do observador se detivesse na haste de um erva, no brilho das flores e no esplendor colorido das borboletas. Hoje a mesma paisagem apresenta-se tal como vislumbrada de um avião a jato que a sobrevoa a milhares de metros de altura, e

\footnotetext{
${ }^{41}$ LINS, Osman. "Homenagem a Graciliano Ramos” In: BRAYNER, Sônia (org.) Graciliano Ramos, Coleção Fortuna Crítica / Rio de Janeiro: Civilização Brasileira, 1978. (Cf. p. 192)

${ }^{42}$ Idem.
} 
por essa razão, precisamente, o campo visual torna-se mais amplo e mais difuso, em detrimento da focalização pormenorizada, característica de épocas passadas (ROSENTHAL, 1975: p. 68).

Eis o motivo de tanto Lafetá como Candido explicitarem categorias de análises incompatíveis com São Bernardo. A velocidade mencionada pelo primeiro é a causa da aparente ausência de recursos. Paulo Honório narra segundo um modo de ver o mundo, ainda que em pleno sertão nordestino, completamente arraigado à nova experiência sensorial a que o século XX foi submetido em função de sua mecanização. Graciliano, por sua vez, explora seu narrador, suas características de modo geral, e produz um texto muito diferente do que se havia feito antes desse século.

Nos nossos termos, acompanhando Osman Lins, o romance é simetricamente invertido: enquanto no plano da enunciação do narrador verdadeiro observamos esse "escritor na plenitude dos recursos", o autor fictício funciona como meio de despistar ou desmentir "esse processo estilístico em maturidade", servindo-se de concepções ou valores de composição que não se realizam (lembrando ao leitor algo aparentemente familiar); ou que, quando diz que não vai se realizar, já foram realizados de modo inverso (num efeito de gangorra permanente, gerando certo efeito de contradição).

Em Semiótica, o recurso técnico empregado por Graciliano Ramos designa-se por enunciação-enunciada: ocorre a simetria entre o discurso desse narrador verdadeiro e o do narrador fictício; porém eles são inversos: quando Paulo Honório diz que "vai" revelar, mais à frente, o que não revelaria a ninguém face a face, no plano da enunciação do "narrador verdadeiro" 43 o revelado é o contrário: o que foi lido, desde o início, já é o que nenhum autorfictício diria, e fica-se com a impressão de que tal capítulo é acidental, despistando o leitor típico de romance, à espera das revelações que Paulo Honório fará no futuro.

Rolando Morel Pinto, a propósito, percebendo essa estratégia do texto, faz o seguinte raciocínio sobre as divagações de Paulo Honório a respeito da exclusão da paisagem em sua narrativa durante uma viagem de trem. A citação a seguir inclui o trecho analisado; o que, apesar de alongar um pouco mais nossa justificativa, encurtará o caminho de nossos objetivos.

'Uma coisa que omiti e que produziria bom efeito foi a paisagem. (...) via de relance, pelas outras janelas, pedaços de estações, pedaços de mata, usinas e canaviais. (...) Vi também novilhos zebus, gado que, na minha opinião, está acabando de escangalhar nossos rebanhos.

\footnotetext{
${ }^{43}$ Adotemos, por ora, o termo usado por Osman Lins, sabendo que ele é inadequado, já que supõe, ainda, um tipo de autor-ficcional determinado pelo Realismo.
} 
Hoje isso forma para mim um todo confuso, e se eu tentasse uma descrição, arriscava-me a misturar os coqueiros da lagoa, que apareceram às três e quinze, com as mangueiras e os cajueiros, que vieram depois. (...)'

Não obstante essa afirmação categórica do narrador, a omissão da paisagem não é absoluta em todo o romance. A ação pode ser perfeitamente localizada, e o meio ambiente se corporifica à proporção que surge a necessidade ${ }^{44}$.

Rolando Morel Pinto detecta o fator determinante do efeito de deslocamento da descrição da paisagem para a mente do narrador, isolada do momento em que a ação se desenrolou. A paisagem apenas não está no lugar onde comumente seria colocada. Mas, à medida que for necessária, ela se corporifica no momento em que se desenrola o episódio da viagem de trem (mas isso, é claro, segundo o leitor e sua concepção de gênero e valor literário). Isto é, o efeito de ausência de descrição se dá pelo fato de não ter sido construída segundo um padrão conhecido. Mas ela está em toda parte do livro exatamente da forma que ele acaba de dizer: como se fosse vista de relance, fragmentada pela velocidade dos acontecimentos.

Esse desmembramento da cena da ação (dentro do trem) e do cenário exige a experimentação sensorial da linguagem literária; permite ao leitor a percepção naturalista/realista dos efeitos de descrição. Ao apresentarem-se primeiro as ações dentro do vagão do trem (conforme o padrão realista de apresentação de fatos), para, depois, apresentar-se a paisagem, na mente do narrador, fora do âmbito de onde se desenrolaram as ações, ocorre uma espécie de dobra da realidade: se a deslocamos da memória do narrador para a cena do trem, compomos um quadro típico literário, mas, se não, se a preservamos conforme o padrão próprio da obra, temos que a realidade não é objetiva ("hoje isso forma para mim um todo confuso"). Focada a ação dentro do trem, que se paralisa pelo foco narrativo, a velocidade do que está fora desse foco é imperceptível, sendo impossível um olhar que abranja esse desdobramento de realidade. É um claro questionamento dos falsos efeitos de percepção do real atribuídos a certas técnicas de descrição.

Esses deslocamentos ou destaques de elementos deslocados de seus lugares típicos no romance não só produzem uma experiência sensorial nova da linguagem literária como deslocam o objeto da realidade de seu lugar específico: a realidade não é mais palpável e objetiva, isolada do olhar, condicionando um foco capaz de capturar a totalidade do mundo. A realidade desdobra-se: parte dela está fora do olhar, outra na mente, compondo um todo que configu-

\footnotetext{
${ }^{44}$ MOREL PINTO, Rolando. Graciliano Ramos: Autor e Ator / Assis, S.P: Ed. da Faculdade de Filosofia, Ciências e Letras de Assis, 1962. (Cf. p. 60)
} 
ra a narração de São Bernardo. Essa fragmentação apenas diverge do padrão modernista no que concerne à característica humana de percepção: seria uma espécie de "cubismo humanizado pelo olhar" que a própria experiência sensorial do mundo moderno produz e se apresentaria como padrão organizado da literatura diferente em função de que a realidade perceptivelmente, embora a mesma, não pode mais ser vista de outra forma.

Tal é a confusão em que se encontra quase toda a crítica desse romance em função desse processo de composição literária. O que levou, inclusive, Álvaro Lins a julgá-lo inverossímil, confundindo o que emprega Graciliano Ramos como técnica de ficção com o modo de Paulo Honório planejar a escrita. Ao não perceber na "aparente desordem" do romance uma proposta oposta àquela com que se apresentavam os romances tipicamente, os níveis de discurso do livro são harmonizados, unificados e totalizados conforme a expectativa de que a realização da escrita seja idêntica aos planos de Paulo Honório.

Embora Osman Lins tenha demonstrado não haver esse "solilóquio perplexo" apontado por alguns críticos, no capítulo 1, e que aí está a mais notória demonstração da maturidade do romancista, isto é, o estilo não é "documento concreto" (hipótese de Rui Mourão) da inabilidade do narrador, pelo contrário; ele próprio não se desembaraçou da ilusão produzida pela simetria entre o nível discursivo e o nível narrativo do romance: “O romance tem um duplo estatuto semiótico: é um fenômeno linguístico (narrativa), e também um circuito discursivo (carta, literatura)", continua Júlia Kristeva, "A narrativa apresenta-se como uma história, o romance, como um discurso (...)"45. Quando Osman descreveu a mais enérgica organização do tempo e do espaço no capítulo 1, e a nomeou como "plataforma física" em que vai se desenrolar o drama, não percebeu que essa plataforma (cenário construído a partir de fragmentos espaciais e temporais), em que Paulo Honório vai surgir debruçado cenicamente sobre os manuscritos (os textos do Gondim, os dele próprio), é o palco do discurso do narrador ficcional projetado pela enunciação do narrador verdadeiro. Eis o que ele deduz pela identificação de que o estilo não é claudicante, mas para a qual se fecha em virtude de não ter atribuído a tal construção cênica outra perspectiva senão a do escritorpersonagem típico. Ele não atribui completamente a autoria da realização escrita a Graciliano, mas em parte a ele, em parte a Paulo Honório, como processo mimético absoluto. E isto dificulta sua análise. Ainda está preso ao pressuposto de representação realista das operações escritas de um autor-fictício escritor.

\footnotetext{
${ }^{45}$ KRISTEVA, Julia. Semiótica do Romance, Lisboa: Ed. Arcádia, 1977. (Cf. p. 65)
} 
O artifício de atribuir ao seu protagonista Paulo Honório a autoria do livro permite a Graciliano Ramos, cujo ouvido era extremamente sensível aos ritmos e matizes populares da língua, imitar a escrita possível de um homem inculto e ríspido (embora com leituras) - e creio poder acrescentar que essa imitação constitui na verdade um dos feitos mais bem-sucedidos da nossa Literatura. ${ }^{46}$

Osman Lins, por um motivo que ainda não compreendemos, acaba divergindo de Rui Mourão e dizendo o mesmo que o crítico mineiro. Fecha-se para a abertura de perspectiva que deu início a uma nova compreensão do romance de Graciliano Ramos por motivo de, no fim das contas, não perceber que não há a descrição de uma possível escrita de Paulo Honório, mas sim descrição de suas articulações mentais em relação a uma possibilidade de escrita. Essa tendência, porém, de fechar-se diante de outras perspectivas possíveis que, segundo Lafetá, possibilitariam os ecletismos facilitadores, não ocorre única e exclusivamente com esses dois grandes críticos; parece ter imperado mesmo naquelas críticas produzidas com mais segurança, como a de Valentim Facioli: após verificar todas as evidências de que o autor valoriza o neorrealismo como a concepção exata da produção literária, diz que "Esse quadro relativamente estreito não é harmonioso, não é isento de contradições. Bastante lembrar que o romance Angústia apresenta diferentes graus de ruptura em relação àquelas disposições [neorrealistas do autor]"47. Há uma espécie de unificação do todo (da obra, concebida na cadeia da recepção) sob o dispositivo do nome Graciliano Ramos, autor antimoderno, construído a posteriori. Graciliano seria a causa da obra, não a obra a origem do nome. Trataremos disso ao longo das análises.

O caso é que não há a imitação da escrita, mas a descrição escrita do que planeja escrever um homem semialfabetizado: é o fluxo de pensamentos de Paulo Honório que está sendo plasmado pela escrita, daí a sensação de que ele "fale literalmente", a ponto de Lafetá confundir esse recurso mimético de representação aparentemente fonética, isto é, suprassegmental, com a construção das "molduras" panorâmicas dos ambientes de histórias contadas por narradores tradicionais. A inovação de Graciliano - ao construir um tipo de narrativa que permite, inclusive, que o "narrador verdadeiro" assuma sem riscos o que diz Paulo Honório, não o que diria, por exemplo, num trecho como este: "Tive, durante uma semana, o cuidado de procurar afinar a minha sintaxe pela dela [de Madalena], mas não

\footnotetext{
${ }^{46}$ Idem. (p. 189)

47 FACIOLI, Valentim A. "Dettera: Ilusão e Verdade - Sobre a (im)propriedade em alguns narradores de Graciliano Ramos”, In: Revista do Instituto de Estudos Brasileiros n. o 35, p. 43 à 68, São Paulo, 1993. (Cf. p. 49)
} 
consegui evitar numerosos solecismos" - está exatamente na forma que encontrou de pôr em cena um narrador escritor sem a necessidade de ter escrito nada.

Como Paulo Honório poderia saber que cometeu "solecismo" se o que estava procurando era, exatamente, aprender a norma culta? Isso só é possível porque "Graciliano" assumiu a escrita do livro, e não é inverossímil que Paulo Honório "adivinhe" que o modelo linguístico de Madalena seja privilegiado. Que ele perceba ter produzido erro ao tentar usar esse modelo, o que ele não poderia era exatamente falar em "solecismo". Essa inadequação é produzida pelo ponto de vista daqueles recursos de produção literária ligada ao século anterior a Graciliano.

A solução é básica: ele pensa, sente, reage, intui (narra); Graciliano escreve (romanceia), numa enunciação histórica e que não pode ser recuperada completamente (um momento em que ele não é o Graciliano que a história construiu verossimilmente), mas que pode ser recuperado pela análise material do texto. É preciso inverter aquele juízo de Álvaro Lins de que o primeiro livro cujo autor não é um personagem seria Vidas Secas.

Em São Bernardo, surpreendentemente, a escrita não é recurso do narrador, mas a simetria entre os níveis discursivo e narrativo insinua e induz a equivalerem-se: são aspectos discursivos os termos "livro", "pseudônimo", "assinatura na capa”, "dois capítulos perdidos", as falas de interlocutores etc.; esses elementos pertencem também ao nível narrativo, sendo lá “objetos" da ficção produzidos pelo discurso, invisíveis (quando o leitor olha a capa do livro, um leitor que não conhece o autor, por exemplo, e confere lá o nome de Graciliano, faz, sem querer, uma relação dos níveis, em que, dependendo de sua concepção de obra, levará a uma interpretação; essa relação gera pressupostos e subentendidos; o recurso que o autor emprega para isso é a enunciação-enunciada, dois modos de dizer algo sobre a mesma coisa).

Quem primeiro estudou esse tipo de construção discursiva foi Bakhtin, identificando três tipos de uso de palavras ambivalentes, dos quais chama atenção para o fato de um deles ser o emprego de palavras, como "solecismo", que não podem ser atribuídas ao universo lexicológico do personagem ou do narrador, mas ao do escritor. Júlia Kristeva, estudando Bakhtin, diz que "É o escritor que 'fala', mas um discurso estranho [em que] constantemente se apresenta nesse discurso, que deforma.” (KRISTEVA, 1977: pp. 81 e 82). É isto que determina que o romance seja simetricamente inverso, e não simetricamente idêntico, como Angústia, em que o plano da enunciação de Luís da Silva é equivalente ao plano da escrita: “O artigo que me pediram afasta-se do papel. É verdade que tenho o cigarro e tenho o álcool, 
mas quando bebo demais ou fumo demais, a minha tristeza cresce. Tristeza e raiva. Ar, mar, ria, arma, ira. Passatempo estúpido."48

A decomposição da palavra Marina em "ar, mar, ria, arma, ira" mantém sua identidade discursiva com o que realiza Luís da Silva narrando. Mas não há essa simetria de identidade no caso do segundo romance de Graciliano. Por isso, também a questão temporal de São Bernardo apresentou dificuldades: "precipitando-se" em sua análise, chega-se a resultados perturbadores. Se a objetivação, em Angústia, da escrita de Luís da Silva (na decomposição das sílabas do nome de Marina) produz a simetria temporal e espacial da realização da escrita; em São Bernardo há um desajuste: a realização escrita não se harmoniza com o que é dito, a escrita e o dito se contrariam. E o fato de se lançar mão dos verbos no futuro do indicativo, e suas variantes, produz uma lacuna temporal entre o que se realizará e o que está realizado. Isto é, não estão na mesma esteira temporal o dizer e o dito. A análise de Antonio Candido, por exemplo, põe na mesma esteira temporal, sequencialmente, episódios da enunciação e do enunciado, como se não houvesse memória (passado) e presente opondo-se mutuamente como a distinção discurso e narrativa ${ }^{49}$.

Essa questão é crucial para o entendimento global do romance: há uma clara distinção entre presente linguístico e passado memorial no texto. O primeiro, tratando da questão presente continuamente - conquistar ou "escrever um livro" destinado a nos contar seu "fito na vida", a conquista da fazenda, ocorrida no passado, correspondendo ao segundo aspecto temporal que se tornou objeto exclusivo da crítica. O curioso nisso é que, em termos literais, não há uma organização cronológica linear. O efeito produzido pela superposição do presente enunciativo sobre o passado (em suas variações de presente do passado, futuro do pretérito), em termos de enunciado, é de indeterminação cronológica e sensação de um presente contínuo donde se fica sabendo sobre os acontecimentos. Tudo ocorre no presente da enunciação, sobre o pano de fundo da memória.

Assim, enunciação e enunciado se distinguem por oposições tanto temporais como em termos de valores; o que nos confirma Valentim Facioli quando diz que há “(...) uma espécie de desencontro permanente, sempre encenado na narrativa, entre o Paulo Honório pro-

\footnotetext{
${ }^{48}$ RAMOS, Graciliano. Angústia / Rio de Janeiro: O Globo; São Paulo: Folha de São Paulo, 2003. (Cf. p. 6)

${ }^{49}$ Essa abordagem niveladora (portanto conforme o romance realista/naturalista) é também a de Weber: "Ocorre que no romance de Graciliano não há praticamente passagem do presente para o passado (...) No presente, além disso, se lida com duas frações temporais: a do início do narrar, dois anos após a morte de Madalena (cf. cap. XXXVI) - que daria origem aos capítulos iniciais e à rememoração - e à do epílogo." WEBER, João Hernesto, "São Bernardo e Os Dilemas da Tradição" In: FICHER, Luís Augusto. Caderno Porto e Vírgula, Graciliano Ramos, (org. Luís Augusto Ficher), Secretaria Municipal da Cultura, Porto Alegre, 1993. (Cf. pp 65, 66)
} 
tagonista e o Paulo Honório narrador" (FACIOLI, 1993: p. 50). Esses aspectos justificam a pesquisa de São Bernardo numa perspectiva de análise diferente da que se aplica ao romance realista ${ }^{50}$. Como ficção do romance, ou como conclusivamente diz Zilberman em seu trabalho sobre São Bernardo, uma metaliteratura, pode-se dizer que a superfície plástica que o envolve desempenha papel de representação do "ato de construir", representação que serve como disfarce do discurso crítico sobre o gênero romântico e disfarce do debate político da função do romance na organização social. Evidentemente, esse espelhamento provoca certo fenômeno de inflexão e reflexão, repetindo-se ao longo dos capítulos, na tentativa de comunicar ao leitor o artifício de significação e construção da obra em forma de instrução dada na relação processada no nível da enunciação-enunciada; para, com isso, levá-lo à percepção da função social do gênero romance. Os desencantos do protagonista não deixam de se relacionar com o desencantamento da linguagem como meio de resolver as questões empíricas, o que, neste sentido, levaria o leitor a inúmeras desilusões, pelo desmascaramento da ilusão promovida pelo romance enquanto linguagem apenas. Ou mais simplificadamente, nas palavras de Hermenegildo Bastos:

Graciliano Ramos é um caso raro entre nós de escritor cuja literatura é crítica da realidade e, ao mesmo tempo, da própria literatura. É uma obra que, ao se construir como crítica da realidade, não se deixa enganar pelo veículo mesmo da crítica e, dessa forma, passa a incluí-lo no objeto a ser criticado. Com isso, o que seria veículo, instrumento, meio, passa a integrar o objeto da crítica, perdendo a condição de neutralidade. ${ }^{51}$

Parece-nos que Graciliano via na vida o que a maioria dos romancistas só via na arte. Há toda uma trama nesse romance em torno da linguagem (centralizada no tipo de texto romance) cujo intuito é "desmistificá-la", mostrar como ela opera e "se constrói”, como submete a realidade em hierarquias por homologia, como define "o gosto" e o "tipo socialmente eleito e legitimado a determiná-lo". E é esse estrato da linguagem, que rege comportamentos e atitudes mentais, dirigindo as ações, que passa a ser sondado pelo protagonista mesmo que ele não possa alcançá-la. Paulo Honório suspeita de que seu "novo fito na vida" é superá-la quando diz: "As pessoas que me lerem terão, pois, a bondade de traduzir isto em linguagem literária, se quiserem." Isto é, traduzir sua "memória" em "romance", pois diz ele: "Não pretendo

\footnotetext{
50 "Devia ferir muito [Graciliano], mais do que a sua catalogação de clássico, (...) o fato de entenderem o rigor da forma e não o que ela trazia de inovador. A ponto de esquecer o geral de uma crítica, ao perceber a pequena intenção que o elevava isolando, e explodir: ‘Sacanas!'” (RAMOS, 1987: p.19)

${ }^{51}$ BASTOS, Hermenegildo José de M. Memórias do Cárcere, Literatura e Eestemunho / Brasília: Editora Universidade de Brasília, 1998. (Cf. p. 41)
} 
bancar escritor", o que significa despojar-se ou abrir mão das técnicas de ilusão do texto literário como fonte de prazer estético apenas, o que ele deduz observando Dona Glória "malucando sob as laranjeiras do pomar lendo romances". Em termos de enunciação-enunciada, decorre daí o seguinte efeito: o que lemos já é uma linguagem literária; que, se a traduzíssemos, teria forçosamente que assumir os aspectos da escrita que Paulo Honório julga verossímil; portanto, contrários ao que realizou Graciliano Ramos. O jogo da comparação do que diz Paulo Honório confrontado pela realização de Graciliano Ramos revela significados não ditos literalmente pelo escritor, mas que são preenchidos pela interpretação do leitor, sendo observador alheio, mas participante da história quando constrói o sentido. 


\section{SEGUNDA PARTE}

\section{Estrutura e percepção: a ficção do leitor}

Antes de iniciar este livro, imaginei construí-lo pela divisão do trabalho. ${ }^{52}$

São Bernardo tem início com esse período capcioso e único em sua estrutura. Lembra algo familiar ao leitor acostumado aos romances, gerando a expectativa de que o narrador seja um autor-fictício ou o personagem que escreve sua própria história. Os sintagmas "este" e "livro", introduzidos pela enunciação de um "eu" do verbo "imaginei", promovem, porém, um tipo de construção que bifurca o texto em duas direções:

- apontando para a história, o enunciado: os episódios ocorridos "Antes de iniciar", cujo primeiro fenômeno é o da ilusão de que "há passado antes de percorrer as páginas do livro", num ato de leitura que torna o "material concreto" em fictício; o que inclui "a escrita presente como fato do passado". Acabada, inserida no presente do "ato de leitura", a escrita torna-se referência das alusões da escrita de Paulo Honório. Contudo, não se menciona o fazer realizado do romance, exigindo a complementação interpretativa do leitor, mediante sua expectativa de texto literário;

- apontando possibilidades de interpretação concomitantes à primeira: na enunciação ${ }^{53}$, graças ao aspecto do verbo infinitivo da oração reduzida (produzindo a presentificação) e pelo despertar das convenções do gênero - contidas nos sintagmas "este", "livro" e "imaginei”, preenchidos por antecipação como "romance". A primeira alternativa é muito comum, corresponde à leitura pragmática do texto, causadora de ilusão. Mas essa segunda alternativa é aquela capaz de inverter os processos da primeira e revelar os elementos ficcionais causadores da ilusão referencial. Por exemplo, o verbo infinitivo "iniciar", na primeira leitura, é tomado frequentemente como "escrever": "Antes de escrever este livro". A segunda leitura inverte o processo e mostra que a alternativa de que "Paulo Honório escreve" é acompanhada pela possibilidade de que não tenha escrito nada.

\footnotetext{
${ }^{52}$ Doravante só indicaremos os capítulos em questão e, quando já estiverem mencionados, a página.

53 “Tenta-se, assim, definir enunciação pelo seu duplo papel de mediação ao converter as estruturas narrativas em estruturas discursivas e ao relacionar o texto com as condições sócio-históricas de sua produção e de sua recepção.” (BARROS, 2001: p. 5)
} 
Na sentença "Antes de iniciar este livro", o infinitivo funciona como estaca zero das idas e vindas no tempo. Ele torna o "escrever um livro", no enunciado, contemporâneo do ato de leitura:

Cada vez que um locutor emprega a forma gramatical do "presente" (ou uma forma equivalente), ele situa o acontecimento como contemporâneo da instância do discurso que o menciona. É evidente que este presente, na medida em que é função do discurso, não pode ser localizado em uma divisão particular do tempo crônico [isto é, o do calendário] porque ele admite todas as divisões e não se refere a nenhuma em particular. ${ }^{54}$

Isto já constitui um procedimento de persuasão do destinatário, ou seja, uma etapa de fazer persuasivo sobre o leitor, já que é ele, na interação dialética texto/leitor, quem torna possível esse presente e, a partir das coordenadas do enunciado, atualiza como contemporâneo do discurso o livro que lê como resultado do processo de construção do livro exibido pelo narrador. E nesse momento entra em jogo o que Iser chama "exercer nossas capacidades", interação sem a qual não haveria prazer estético.

\footnotetext{
O autor e o leitor participam portanto de um jogo de fantasia; jogo que sequer se iniciaria se o texto pretendesse ser algo mais do que uma regra de jogo. É que a leitura só se torna um prazer no momento em que nossa produtividade entra em jogo, ou seja, quando os textos nos oferecem a possibilidade de exercer as nossas capacidades. ${ }^{55}$
}

O leitor é lançado, neste primeiro período, na fronteira entre realidade e ficção, cabendo a ele decidir por qual caminho guiar-se, compondo o sentido. Ou, pego de surpresa como de fato o é, no caso de São Bernardo -, deixar-se guiar até determinado ponto com o olho numa e noutra possibilidade. E o autor, prevendo os sucessos ou insucessos dessa "abertura de perspectiva" de leitura, amplia os horizontes de significação sucessivamente ao “jogar" com outras probabilidades de "início": "O pior é que já estraguei diversas folhas e ainda não principiei", diz o narrador ao final do capítulo 2. Ora, o procedimento técnico implicado nesse primeiro período do romance é das mais graves sutilezas: o início do romance não coincide com o início da narrativa de Paulo Honório, mas é o tempo todo relacionado a ele pela relação comparativa.

\footnotetext{
${ }^{54}$ BENVENISTE, Émile. "A Linguagem e A Experiência Humana" In: Problemas de Linguística Geral II / Trad. Eduardo Guimarães ... [et alii]; Campinas, S.P: Pontes, 1989. (Cf. pp. 74 e 75)

${ }^{55}$ ISER, Wolfgang. O Ato de Leitura: Uma Teoria do Efeito Estético - Vol. 2 / trad. Johannes Kretschmer. São Paulo: Ed. 34, 1999. (Cf. p. 10)
} 
A partir dessa relação se põem em andamento algumas vias de significação - das quais se apreenderão apenas as que assegurarem ao leitor alguma característica com o que é familiar, em literatura, ou tiver aspecto verídico. Trata-se de um processo cuja variação, conforme os contextos, é praticamente infinita: o próprio texto parece incluir as contingências às quais os atos de fala estão sujeitos na comunicação (com a diferença de que, na linguagem em ato, o falante pode corrigir falhas interpretativas do enunciatário; enquanto, no texto, a ficção de um leitor antecipa-se a possíveis falhas em forma de previsão: "leitor desavisado", "leitor amargo", "leitor apressado" etc. são instruções do texto que surgem a partir de reações previstas supostamente). Em São Bernardo, a estratégia é bem diferente: a construção do leitor fictício começa de chofre, na própria estrutura sintática do texto. O falseamento do início constrói dois tipos de leitores de romance.

Algumas noções semióticas são fundamentais à compreensão do fenômeno discursivo implicado nesse processo: sabemos que enunciação é fato ligado ao dizer; e o dito, ligado ao enunciado. Há casos em que se lança mão de estratégias discursivas cujo dizer (enunciação) assume aspecto de dito (enunciado). Um bom exemplo desse processo é-nos oferecido pela análise de "Saudosa Maloca" realizada por Luis Tatit. Os procedimentos técnicos de que lança mão Adoniran Barbosa são semelhantes aos de São Bernardo: "Com esses recursos, o discurso produz sensação de presente enunciativo no interior do tempo passado, típico do enunciado" ${ }^{\text {. }}$. Vimos acima que a oração subordinada adverbial temporal reduzida de infinitivo "Antes de iniciar este livro" instaura discursivamente o presente linguístico, estaca zero de idas e vindas no tempo realizadas pelo enunciador. O processo em que ocorrem idas ao passado é chamado de desembreagem, enquanto a realização em sentido oposto nomeia-se embreagem.

\footnotetext{
${ }^{56}$ TATIT, Luiz. Análise Semiótica Através das Letras / São Paulo: Ateliê Editorial, 2001. (Cf. p. 42)
} 


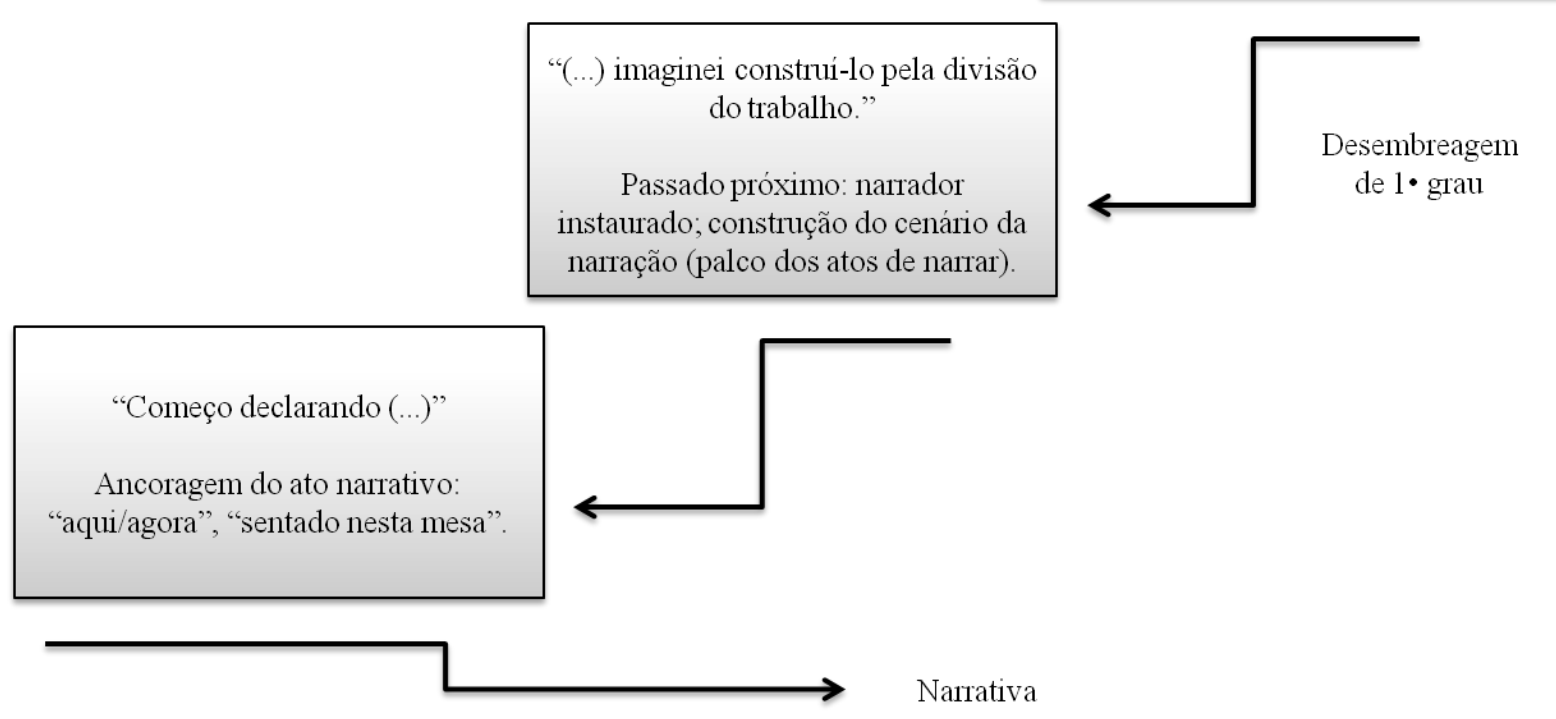

Figura 2: quadro de construção cênica do ato narrativo

O verbo "imaginei" desembreia o tempo do discurso para o tempo da narrativa, instaurando o narrador; não o verbo "iniciar" da reduzida, cujo aspecto não contém temporalidade, mas trânsito do evento em que o presente é a estaca zero e não pode ser localizado em nenhuma divisão particular do tempo cronológico do romance (diferentemente do que acontece com o narrador, cujo presente está localizado cronologicamente após 1930); tornando o evento - compor um livro -, fato contemporâneo do discurso, o que se produz é o efeito de simetria entre "livro fictício" e livro real.

Assim, o eu Paulo Honório que será objetivado no alpendre da fazenda após alguns parágrafos - junto a um dos colaboradores, o Gondim, tratando do assunto sobre como escrever o livro - terá todas as características de um ele, no interior do enunciado, atualizando-se num aqui/agora: será daí que se passará à narração do passado memorial, isto é, da história de fato.

E quando inicia a narrativa propriamente dita com a sentença "Começo declarando que me chamo Paulo Honório", não há uma volta ao "presente linguístico", mas instauração de um "agora", no passado próximo, que permite as relações comparativas entre a instância discursiva e narrativa. Isto é, o começo “Antes de iniciar” funciona apenas como presente do 
ato discursivo e de leitura; o "começo declarando" está ancorado no passado e funciona como presentificação da situação do ato de narrar, dando continuidade aos episódios desenrolados no projeto de construção do livro pela divisão do trabalho, situado, ainda, "antes de iniciar" o livro em direção, no futuro, ao produto final de composição do romance.

Assim é construído o intervalo temporal, pela promessa de realização, no futuro, da escrita, cuja antecipação de que o "livro de Graciliano Ramos" já seria o resultado somente é possível pela interpretação do leitor e no seu imaginário.

A estratégia, portanto, da construção desses dois capítulos iniciais é esta: instaurar um novo presente, em forma de agora, no passado próximo, o que possibilitará, pela enunciação-enunciada, as relações entre marcas discursivas e atos narrativos do eu Paulo Honório dentro do mesmo cenário constituído no plano da memória. Visualizaremos, no quadro abaixo, a construção do fazer persuasivo do enunciador, agindo sobre a competência do enunciatário.

Etapa 1: Fazer-crer

Nível discursivo

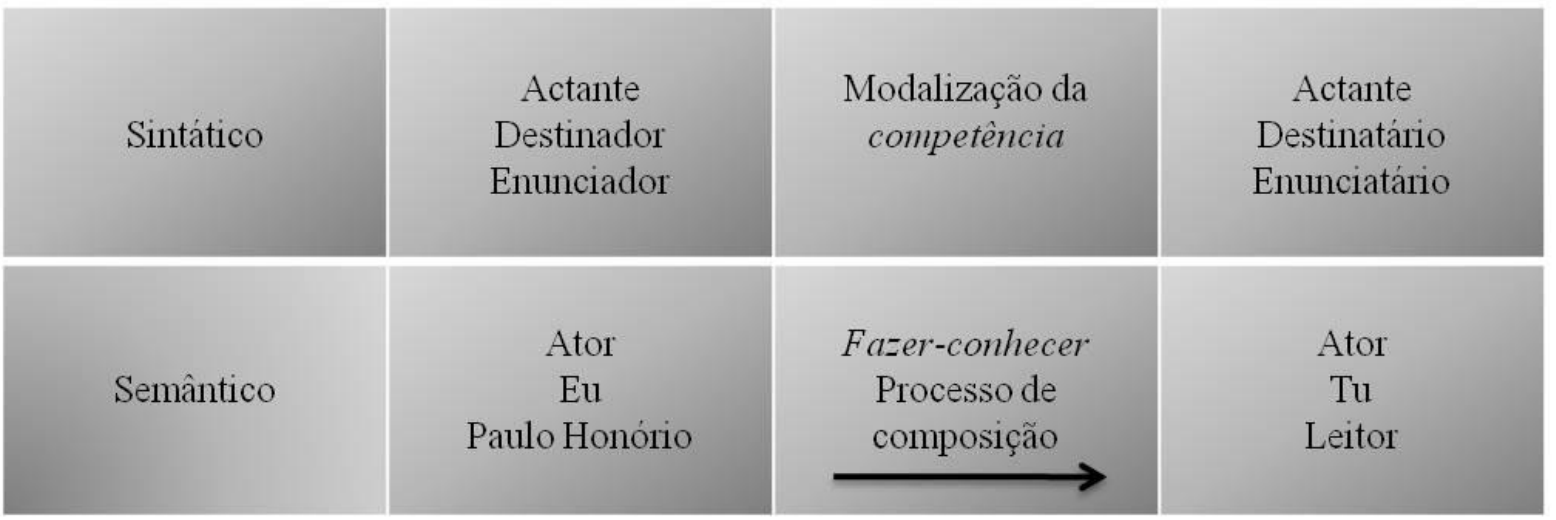

Figura 3

A dotação de competência semântica ou manipulação cognitiva tem todas as características do programa de competência e deve ser entendida como um contrato fiduciário, em que o destinador, graças a um fazer persuasivo, busca a adesão do destinatário. (...) O destinatário é levado a efetuar uma escolha forçada. (...) O fazer persuasivo define-se como um fazer-crer e, secundariamente, como um fazer-saber, e o fazer interpretativo, como o crer, ou melhor, como um ato epistêmico que leva a crer. (BARROS, 2001: pp. 37 e 38)

Notemos que o leitor não é uma categoria sintático-semântica (enunciatário) preenchida artificialmente com a segunda pessoa do discurso, mas sim uma categoria duplamente articulada: imanente ao texto, como simulacro de uma interação discursiva (simulando uma conversa do texto com o leitor); e, sob as mesmas características fora do 
texto, já num âmbito existencial, social ou mesmo ontológico. A parcela do enunciatário, dentro do texto, não será preenchida de sentidos alheios ao leitor fora do texto, mas conforme elementos reconhecíveis (marcas de discurso compartilhadas cognitivamente) e que atendam suas expectativas: "tomei em minhas mãos um romance", portanto uma "não verdade que simula ser verdade", isto é, algo verossímil, parecido com o que se tem por verdade etc., ou seja, instaura-se uma relação dialética entre texto e leitor cujo enunciado será a base da comparação.

No caso do segundo romance de Graciliano, esta é uma condição sine qua non que antecede o ato de leitura do romance: a relação de confiança que se estabelece fora do âmbito formal, determinada pelo gênero romance, está inserida na perspectiva do texto e torna-se instrução de leitura. O leitor de São Bernardo já assinou parte desse contrato ao manifestar interesse pela leitura, antes do ato propriamente dito. Daí a coerência de enunciar-se uma oração subordinada adverbial temporal reduzida de infinitivo, "Antes de iniciar este livro", isto é, "Antes de este livro ter sido iniciado, eu imaginei construí-lo pela divisão do trabalho". Ora, o leitor esperado pelo enunciador é este que procurou um romance, uma ficção, mas o que ele pretende dizer é "leia-o como não romance ainda", garantindo a adesão do leitor por antecipar uma possibilidade diferente da usual. Afinal, pode-se supor de imediato que tal projeto falhou, mas não anular o seu significado dentro do horizonte global do romance. E a explicitação do projeto determinará valores opostos aos de uma obra literária "esperada", induzindo o leitor a escolhas forçadas (mesmo que por oposição). Conclui-se, assim, que o leitor fictício de São Bernardo é construído na estrutura sintática da narrativa, como veremos no próximo capítulo, na análise narrativa.

\footnotetext{
As perspectivas do texto visam certamente a um ponto comum de referências e assumem assim o caráter de instrução; o ponto comum de referências, no entanto, não é dado enquanto tal e deve ser por isso imaginado. É nesse ponto que o papel do leitor, delineado na estrutura do texto, ganha seu caráter efetivo. Esse papel ativa atos de imaginação que de certa maneira despertam a diversidade referencial das perspectivas da representação e a reúnem no horizonte de sentido. O sentido do texto é apenas imaginável, pois ele não é dado explicitamente; em consequência, apenas na consciência imaginativa do receptor se atualizará. (ISER, 1996: vol. 1. p. 75)
}

“A iniciativa de ler romance", conforme as características socio-históricas, insere-se na categoria sintática enunciatário, dentro do texto. Isto é, preenche-se essa função sintática com concepções construídas através de uma praxe: uma interação social anterior ao ato de leitura propriamente dito. A ilusão de que "o ato de escrever" materializa-se como uma ação 
concomitante ao ato da leitura é socio-histórica. Advém de uma concepção de literatura. Os sintagmas "este livro" provocam a ilusão referencial temporal de presente do passado pela referência material e seus correlatos imediatos (livro, nome na capa, dois capítulos etc.); o plano narrativo, enunciado, absorve-os conforme a expectativa do leitor, levando-os para o campo ficcional, no passado do narrador. E, no caso de São Bernardo, imediatamente o passado será revelado pelo ato presente de ler: pois é "deste livro em minhas mãos que se fala" ou "de um livro que não posso ver, mas que seria 'parecido' com os que são produzidos nas oficinas editoriais reais"; ou seja, é verossímil.

Evidentemente se devem distinguir narrativa e discurso; a referência do termo "livro" $e ́$ o sentido ou suas acepções correntes no contexto de atualização: o "livro", ou romance de Graciliano Ramos, não faz parte da ficção senão pela relação enunciado versus enunciação. Essa estratégia narrativa marca uma das singularidades de São Bernardo. O primeiro período está fortemente vinculado ao correlato "realidade" imediata, o mais próximo possível. Mas tal real imediato muda no curso da história social à medida que o gênero romance se modifica em termos de valor cultural e literário (o termo "livro" não tem o mesmo sentido de 75 anos atrás: seu significado é reposto à medida que se modifica, em termos de status literário, no tempo); tanto é que a maior parte dos leitores (para não dizer a totalidade dos que tivemos contato com o livro) crê estar diante de um prefácio do autor Graciliano Ramos num primeiro momento; ou seja, é uma praxe do gênero absorvida pela narrativa, que não se confirma depois (espécie de pista falsa ou beco sem saída). Porque a matéria temática, no desenrolar do episódio, por ser um dado que não figura entre os assuntos cotidianos corriqueiramente, passa a ter forte indício de ficção: a revelação de que há mais pessoas e critérios envolvidos na produção do romance frustra as expectativas: segundo o senso comum, a obra é autônoma e o autor é o único e exclusivo mentor de sua produção ${ }^{57}$.

Por estranheza, a crítica foi induzida a julgar o processo empregado por Graciliano Ramos como "inverossímil", "negligente", ou a "recontá-lo" de forma "romanesca", suprimindo o que parecia confuso e parafraseando o enredo a partir dos elementos que lá

\footnotetext{
57 “A declaração 'imaginei construí-lo pela divisão do trabalho' soa-nos inteiramente fora de propósito. De acordo com os hábitos de produção literária, sòmente em casos excepcionais se concebe a possibilidade de um romance ser composto a quatro mãos. Existe, e isso ninguém que seja mais ou menos informado desconhece, a velha praxe de escritores, concluída a redação dos originais, passá-los a colegas, para uma leitura prévia e posteriores aconselhamentos e sugestões. Como existe tal viabilidade, passando o primeiro momento da surprêsa, deduzimos que a frase completa não é desarrazoada." Cf. em MOURÃO, Rui. A Estratégia Narrativa de S. Bernardo / Minas Gerais: Suplemento Literário (sem indicações do jornal), (s.d.). Fonte: Arquivo Graciliano Ramos. Série: Recortes / Fortuna Crítica de São Bernardo. IEB-USP.
} 
estão; ou simplesmente ignorando-o por abstraí-lo do processo gerativo. Mas não se levou em consideração que, de fato, este nada mais é que o processo escolhido por Graciliano Ramos. Nele, a participação do leitor, por indução, é crucial; ele é estabilizador do conflito produzido pelo gênero e o valor, a partir do papel de intérprete que lhe é delegado: "calcular". Vejamos como isso se dá na narrativa ou no enunciado. 


\section{A escrita utópica de Paulo Honório}

Antes de iniciar este livro, imaginei construí-lo pela divisão do trabalho.

Dirigi-me a alguns amigos, e quase todos consentiram de boa vontade em contribuir para o desenvolvimento das letras nacionais. Padre Silvestre ficaria com a parte moral e as citações latinas; João Nogueira aceitou a pontuação, a ortografia e a sintaxe; prometi ao Arquimedes a composição tipográfica; para composição literária convidei Lúcio Gomes de Azevedo Gondim, redator e diretor do Cruzeiro. Eu traçaria o plano, introduziria na história rudimentos de agricultura e pecuária, faria as despesas e poria o meu nome na capa. ${ }^{58}$

No discurso inicial do narrador, temos noções de tempo e espaço diferentes do aqui/agora da enunciação: pelo deslocamento do evento para "Antes de iniciar este livro", o narrador nos leva ao enunciado, a partir do imaginei. Com essa manobra, o enunciador determinará a inserção de valores no objeto (livro), cuja disjunção $(\cup)^{59}$ com o sujeito (Paulo Honório) será penosa. O esquema da figura abaixo representa o "programa narrativo" concebido pelo protagonista e que deveria ser seguido pelos coadjuvantes ou destinatários.

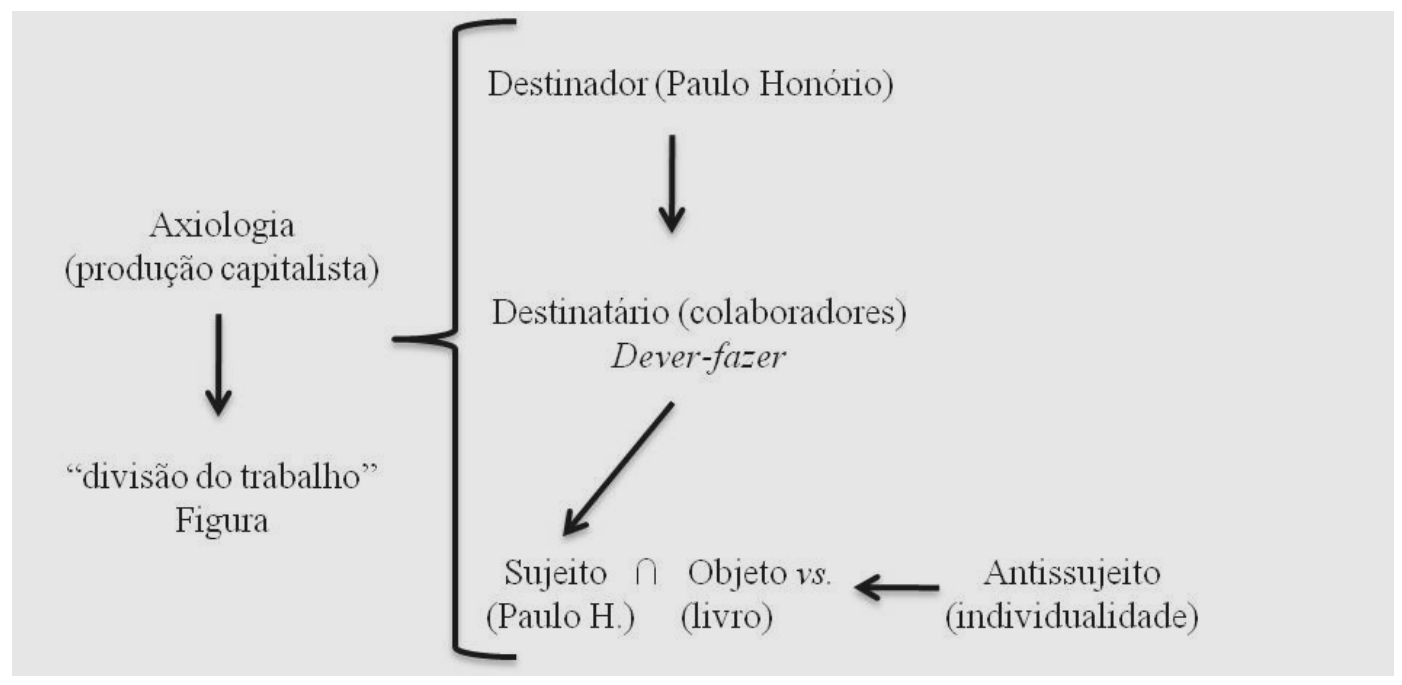

\footnotetext{
58 Observe-se que, na leitura linear, o trecho "poria meu nome na capa" tem como correlato "este livro". Geralmente se ouve referir a este aspecto pela menção de que o nome na capa do livro é o de Graciliano Ramos, em termos relacionais. Ora, basta observamos que o tempo verbal empregado é o futuro do pretérito, isto é, uma projeção do futuro no passado, que não se realiza nem pode ser conferido no presente: o emprego desse tempo verbal ancora os episódios no passado sem retorno ao presente: é na continuidade do passado que todo processo narrativo se realiza. Ou seja: estamos na "imaginação do narrador"; o processo descritivo do que se sucedeu aí é virtual, mas servirá para atualizar o significado e valor do objeto de seu desejo, o livro que projeta compor.

${ }^{59}(\cup=$ disjunção; e $\cap=$ conjunção). “(...) as polêmicas e os conflitos gerados entre sujeito e antissujeito e as disjunções impostas às funções de sujeito e objeto revelam a predominância das descontinuidades tensivas no âmbito narrativo.” (TATIT, 2001: p. 25)
} 
Compreende-se destinador, em semiótica, como a função desempenhada pelo "manipulador"; isto é, "aquele" que apresenta vantagens (dinheiro, felicidade, conforto etc.) ao destinatário, conforme a realização de fazeres por ele definida e apenas através dele possível. O destinador (como as funções de destinatário, objeto, sujeito e seus contrários) pode ser preenchido semanticamente de diversas formas e deverá surgir como personagem, ou, em termos semióticos, como ator. Os sujeitos dos fazeres regem, enquanto enunciado, o sujeito do estado (Paulo Honório). Complementando o quadro anterior, a ideia de "divisão do trabalho" revela, pela relação pars pro toto, a ideologia dominante da situação social em que se encontram os personagens.

Contudo, só se apreendem os valores atraentes ou aceitos pelos personagens em suas relações de "conjunção" ou "disjunção" com o objeto-valor. Um sintoma disso encontra-se na passagem "eu poria meu nome na capa" (conjunção) e "estive uma semana bastante animado" (euforia, "bem-estar", estado), antecipando-se ao sucesso da empresa e inserindo os valores virtuais axiomáticos no objeto "livro".

Assim é que tomamos conhecimento de que, para o personagem, é "positiva" a posse do livro nessa circunstância de "produção literária". E as modalidades performáticas querer, saber, poder e fazer, próprias da função do sujeito/colaboradores - são a garantia de sucesso de conquista do objeto. Assim é que se concebem os "colaboradores", sujeitos do fazer, em relação ao "destinador” Paulo Honório, sujeito do estado.

\begin{abstract}
Pela conversão semântica, os valores virtuais, isto é, ainda não assumidos por um sujeito na instância fundamental, são selecionados e atualizados na instância narrativa. A atualização realiza-se em duas etapas: inscrição dos valores em objetos, que se tornam objetos-valor, e junção dos objetos-valor com os sujeitos. Os valores axiológicos virtuais convertem-se, dessa forma, em valores ideológicos, entendidos como valores assumidos por um sujeito, a partir da seleção no interior dos sistemas axiológicos (BARROS, 2001: pp. 27 e 28).
\end{abstract}

E com isto, como já foi dito, vai-se delineando aí um leitor fictício por implicação ou oposição a valores literários compreendidos pela condição socio-histórica da recepção. A figura da divisão do trabalho fornece uma ideia das modalidades que desempenhariam os destinatários, numa situação ideológica. Isto é, "os fazeres e saberes" são tomados como "produtos" oferecidos no mercado de trabalho. É o velho tema da reificação, já de todos nós conhecido, que de intróito se apresenta: Padre Silvestre faria citações morais em latim; João Nogueira se ocuparia da sintaxe; o Gondim, da elaboração formal ou literária do romance; e o Arquimedes, o que hoje seria conhecido como a diagramação do texto. Futuramente, com a 
morte do jornalista Costa Brito, o protagonista "pagaria" (lambugem) os elogios que o jornal Gazeta faria à obra. Mas, apesar da reciprocidade inicial ao projeto, pouco a pouco vão-se apresentar certas "resistências": "João Nogueira queria o livro em língua de Camões. Calculem.”; Padre Silvestre virou-lhe a cara depois da Revolução de 30. A recusa desses dois colaboradores deve ser lida como "disjunção" com o objeto "livro". Assim sendo, eles não assumem os valores axiológicos e, portanto, não participam da mesma ideologia determinada pelo modo de produção capitalista.

Ficando apenas o Gondim, com quem se encontra no alpendre da casa grande, Paulo Honório surgirá de corpo e alma na cena: “A princípio tudo correu bem, não houve entre nós nenhuma divergência." E chega a considerar o diretor do Cruzeiro como "uma espécie de papel destinada a receber as ideias confusas que me ferviam na cabeça." Num estudo sobre São Bernardo, Abel Barros Baptista avalia o conceito de "divisão do trabalho" como figura, já "incorporada” ao sujeito: “(...) figura da iniciativa e do domínio, ou seja, do projeto. (...) cabem-lhe sobretudo as tarefas que a instituem e que lhe permitiriam apropriar-se do produto final, ou seja, traçar o plano, fazer as despesas e pôr o nome na capa (...),60

Isto significa dizer que a ética que deveria orientar as atitudes dos colaboradores era puramente mercadológica, comercial. Para Paulo Honório, então, o sentido de "escrever um livro" é "oportunidade", "utilitarismo", o que o torna mercadoria, mero valor de troca. É por esse motivo que o leitor de romance tradicional implícito no romance começa a se delinear a partir do "objeto-valor livro". Evidentemente, por contrariar a expectativa e produzir duas possibilidades de leitura, pelo efeito da simpatia/antipatia segundo o valor do objeto, é que o leitor mobiliza um juízo de valor literário $x$ para compreensão e julgamento das ações dos personagens. Motivo que leva à maior parte da crítica enxergar Paulo Honório rejeitar a participação dos colaboradores e não contrário.

\footnotetext{
${ }^{60}$ BAPTISTA, Abel Barros. O Livro Agreste: Ensaio de Curso de Literatura Brasileira / Campinas, São Paulo: Editora da Unicamp, 2005. (Cf. p. 105). Define Tatit: "Axiologia é o termo contrário de 'ideologia', cujo valor é preexistente ao sujeito." Cf. (TATIT, 2001: p. 30). Isto é, pelas relações conjuntivas e disjuntivas reconhecem-se as partes de uma mentalidade que supõem uma ideologia, mas não toda a ideologia dentro do universo do indivíduo, a menos que ele assuma os aspectos selecionados no sistema axiológico.
} 


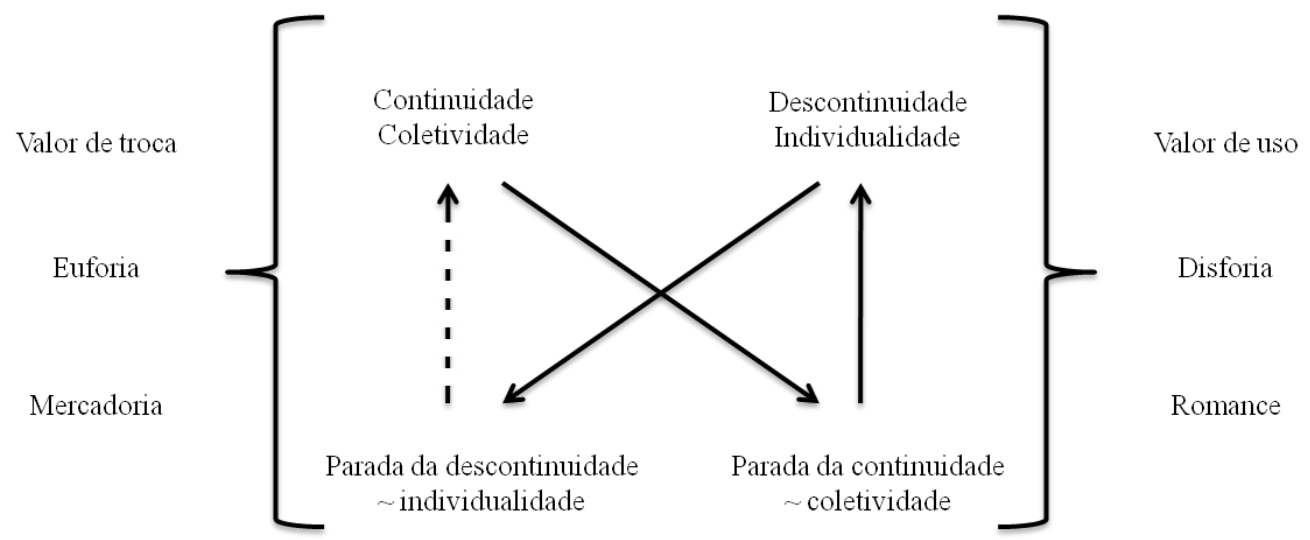

Esta operação caracteriza-se como inserção de valor (preenchendo o "livro", que aparece vazio semanticamente na primeira sentença do romance, com valores de mercadoria, valor de troca, apropriação do discurso individual, na coletividade, como serviço prestado, calculado quantitativamente etc.). Em relação à enunciação, este dado é interno e se processa pela relação enunciação vs. enunciado; não faz parte da concepção pré-discursiva do leitor (cuja expectativa, anterior ao ato de leitura, "era" a de que "este livro" fosse um romance escrito por um autor solitário, com valor de uso). Essa forma de construção do livro é um "antivalor" ${ }^{\prime 61}$ para o leitor usual. Já para o leitor moderno, habituado às vanguardas, constituise em uma experiência possível (apesar de dificilmente se perder de vista o mercantilismo do processo imaginado por Paulo Honório).

Disto decorre o motivo por que a recepção tomará como positiva ou negativa ou simplesmente deixará suspensas, como algo inexistente no livro, certas relações internas e estruturais: há possibilidades de leituras segundo o senso de valor literário. Como dizíamos, o leitor fictício de São Bernardo está inscrito na estrutura sintática da narrativa. E o que nos garante que o discurso esteja sendo dirigido a um leitor de romance romântico se dá, de intróito, pela menção de que "Antes de iniciar" o "narrador imaginou assim", garantindo, pelo desfecho desastroso da composição, como autênticos os valores pré-discursivos ou opostos ao valor de obra delineado no capítulo 1. E, nesse caso, o leitor usual de romance terá sua expectativa atendida pela reconstituição dos aspectos gerais caracterizados por padrões ideológicos de individualismo/originalidade.

61 "O romancista segrega-se. A origem do romance é o indivíduo isolado, que não pode mais falar exemplarmente [coletivamente] (...)" BENJAMIN, Walter. Magia e Técnica, Arte e Política: Ensaios sobre Literatura e História da Cultura / Obras Escolhidas v. 1 / São Paulo: Brasiliense, 1994 (Cf. p. 201). 
Mas, atente-se: a inversão de valores que ocorre aí indica que o que é "natural" para o leitor não o será para o narrador e vice-versa. Observe-se a resistência aos modelos "não padronizados" pela norma e como eles estão participando, na superfície do texto, ainda que o enunciado refira o inverso. A disforia, ou o "mal-estar" do protagonista, ocorrida pelo "desentendimento" com os colaboradores em função da língua que deveria veicular as ideias, pode ou não estar na realização do eu-enunciador: "Mas o otimismo levou água na fervura, compreendi que não nos entendíamos". Nesse momento, começa o processo de "disjunção" entre objeto-valor e sujeito e se revela a "disforia" pela decepção causada e pela descoberta de que a sua língua usual não tinha status de representação coletiva nem literária; assim, os valores virtuais inscritos no objeto "livro" são negados ou não assumidos pelos destinatários.

Ora, ao verificarmos que a estrutura do texto joga com inversões de valores, a probabilidade de que esse processo seja a causa das variações de sentido atribuídas a esse capítulo e das diversas interpretações não é descartável (sobretudo, a causa de certo efeito de antipatia em relação ao protagonista: a maior parte das interpretações desse capítulo indica o contrário do que sucede, a saber, que Paulo Honório rejeita a colaboração dos intelectuais e não que os colaboradores rejeitem as ideias de Paulo Honório).

Assim, São Bernardo é um romance capaz de atender a "duas expectativas" antagônicas pelo menos, a partir do modo como a narrativa é atualizada pelo leitor. Daí pertinentemente Regina Zilberman ter caracterizado São Bernardo como metaliterário: o próprio romance instrui as relações possíveis de compreensão do texto, opondo forma e conteúdo, e induz a escolha deste ou daquele aspecto de valor literário.

É preciso distinguir aqui uma noção importante de leitor: aquele que denominamos leitor implícito, cuja estrutura textual alude ou refere-se diretamente, conforme se caracteriza para Iser, como uma "ficção do leitor" ou apenas parte da estrutura do texto preenchida pelo narrador ou não enquanto narra. Mas este não é bem o caso de São Bernardo: é pela relação entre enunciação e enunciado que o percebemos na estrutura como uma categoria vazia. E, curiosamente, ainda que o narrador fale em "caboclos que me servem" aludindo a tal leitor, o leitor fictício de São Bernardo é praticamente sintático, isto é, sem preenchimento semântico: são os próprios receptores que constroem tais leitores no texto a partir das marcas discursivas, aqui analisadas como metalinguísticas, implicando gêneros discursivos, inseridas semanticamente no texto: 
O domínio das leis do discurso e dos gêneros de discurso (...) são os componentes essenciais de nossa competência comunicativa, ou seja, de nossa aptidão para produzir e interpretar os enunciados de maneira adequada às múltiplas situações de nossa existência. Essa aptidão não requer uma aprendizagem explícita; nós a adquirimos por impregnação, ao mesmo tempo que aprendemos a nos conduzir na sociedade. ${ }^{62}$

Daí a perenidade de leitura do romance: o vocábulo "livro", já na primeira sentença, é uma marca de discurso, dentro do gênero literário de modo geral, cuja compreensão pelo leitor é de um valor que antecede a leitura; ao deparar-se com o "livro" naquelas condições de produção pretendida por Paulo Honório, ocorre uma "falsa explicitação de procedimentos" unicamente com função de opor-se a concepções preexistentes na relação narrativa/discurso; desde então, o ato de leitura passa a preencher o leitor fictício do texto. Tal realização só pode ser processada pelo leitor real ou a consciência imaginativa do receptor.

É por isso que, para o teórico do efeito estético, ao "darmos o sentido do texto" o estaríamos aniquilando: tal significado não pode ser idêntico ao texto porque oculta suas diferentes estratégias de significação e de horizontes possíveis. Isto é, o receptor "não percebe que o efeito estético se transforma em produtos não estéticos.” (ISER, 1996: vol. 1, p. 55). Ora, a antipatia/empatia com o protagonista é o principal efeito estético do romance; a relação de Paulo Honório com o modo de produção literária pretendido por ele produz no leitor este ou aquele efeito, levando-o a inserir o sentido, no texto, segundo as concepções prédiscursivas de valor literário que o antecedem. Esses antecedentes são absorvidos pela estrutura sintática da narrativa e produzem o sentido a ela atribuído: por exemplo, o de que o protagonista recusa a colaboração dos coadjuvantes.

A "invisibilidade" desse processo de construção de Graciliano repercute na crítica, de modo geral, segundo a ideia de que o autor de Vidas Secas é um escritor que, com poucos recursos, alcança o máximo desempenho. Mas voltemos. A empresa de Paulo Honório não tem êxito porque o "livro/romance" é um tipo de produção que, no jogo da fantasia do leitor, de modo geral opõe-se à produção industrial, exigindo do autor sua subjetividade/originalidade e um conhecimento total dos processos de "manufatura" do objeto. Por outro lado, metaforicamente, ela lembra algumas experiências vanguardistas; e decorrem daí dois tipos de recepção crítica possíveis: a que vê na forma algo diferente do

\footnotetext{
${ }^{62}$ MAINGUENEAU, Dominique. Análise de Textos de Comunicação / São Paulo: Cortez, 2004. (Cf. p. 41)
} 
romance tradicional, dando pouca importância ao drama; e a que vê no conteúdo o romance tradicional através de uma forma inabitual e contraditória.

A história de Paulo Honório é simples: ele quer, pode, mas não sabe como fazer um livro sozinho. Portanto, não tendo em si próprio as categorias modais de "saber" e "fazer" individualizados, tenta obtê-las através de uma espécie de intersubjetividade que afinal falha: Padre Silvestre (simbolicamente representado como "ideal político") recebe friamente o protagonista depois da Revolução de 30; “João Nogueira [simbolicamente representando uma tradição literária] queria o romance em língua de Camões, com períodos de trás para diante. Calculem.” Isto é, que fosse escrito em estilo e código desconhecidos por Paulo Honório ou que ele apenas conhecia de longe. Contudo, Gondim permanece um pouco mais na empresa, representando o deslocamento da "reciprocidade" à "não reciprocidade" ao projeto, que ao final revela-se em "total resistência": Gondim lhe diz que discute qualquer coisa, menos literatura, finalizando a conversa categoricamente com as palavras "não pode porque não pode".

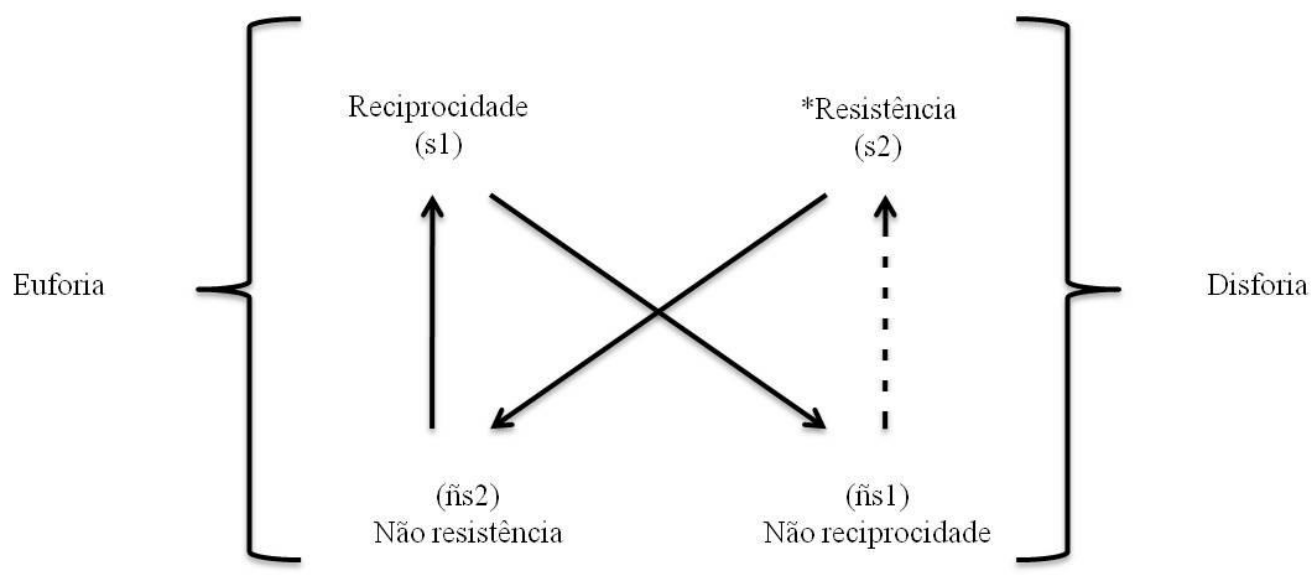

O resultado foi um desastre. Quinze dias depois do nosso primeiro encontro, o redator do Cruzeiro apresentou-me dois_capítulos dactilografados, tão cheios de besteiras que me zanguei:

- Vá para o inferno, Gondim. Você acanalhou o troço. Está pernóstico, está safado, está idiota. Há lá ninguém que fale dessa forma!

Nesse momento, uma nova forma de expressão é aludida: se João Nogueira buscava na tradição clássica um preceito de obra e por tal motivo ficou distante do projeto, a apresentada por Gondim só pode provir de outra tradição, oposta à que o personagem reconhece como "verossímil", provavelmente normatizada pelo Romantismo. 
Azevedo Gondim apagou o sorriso, engoliu em seco, apanhou os cacos de sua pequenina vaidade e replicou amuado que um artista não pode escrever como fala.

- Não pode? perguntei com assombro. E por quê?

Azevedo Gondim respondeu que não pode porque não pode.

- Foi assim que sempre se fez. A literatura é a literatura, seu Paulo. A gente discute, briga, trata de negócios naturalmente, mas arranjar palavras com tinta é outra coisa. Se eu fosse escrever como falo, ninguém me lia.

Esse momento produz reações em Paulo Honório que merecem observação: enquanto enunciado do estado (Paulo Honório) é regido pelo enunciado do fazer (dos colaboradores); isto é, a relação disjuntiva com o objeto vai produzir no protagonista um saber que ele não tinha. Em Semiótica esse processo é nomeado dotação de competência. A reação de "assombro" pela descoberta de que "não pode escrever como se fala" é decisiva para a compreensão do que representa Paulo Honório na coletividade ou universo social da ficção: aqui fica claro que ele não é leitor de obra literária, tampouco sabe escrever; suas referências de linguagem não advêm da literatura. A sua dependência do sujeito do fazer define seu estado. Isto é, o sujeito do fazer não assume os valores axiomáticos inscritos no processo, produzindo decepção no destinador Paulo Honório, seu "não vínculo" com o coletivo, atualizando seu estado de dependente das decisões daqueles que detêm a competência das realizações performáticas.

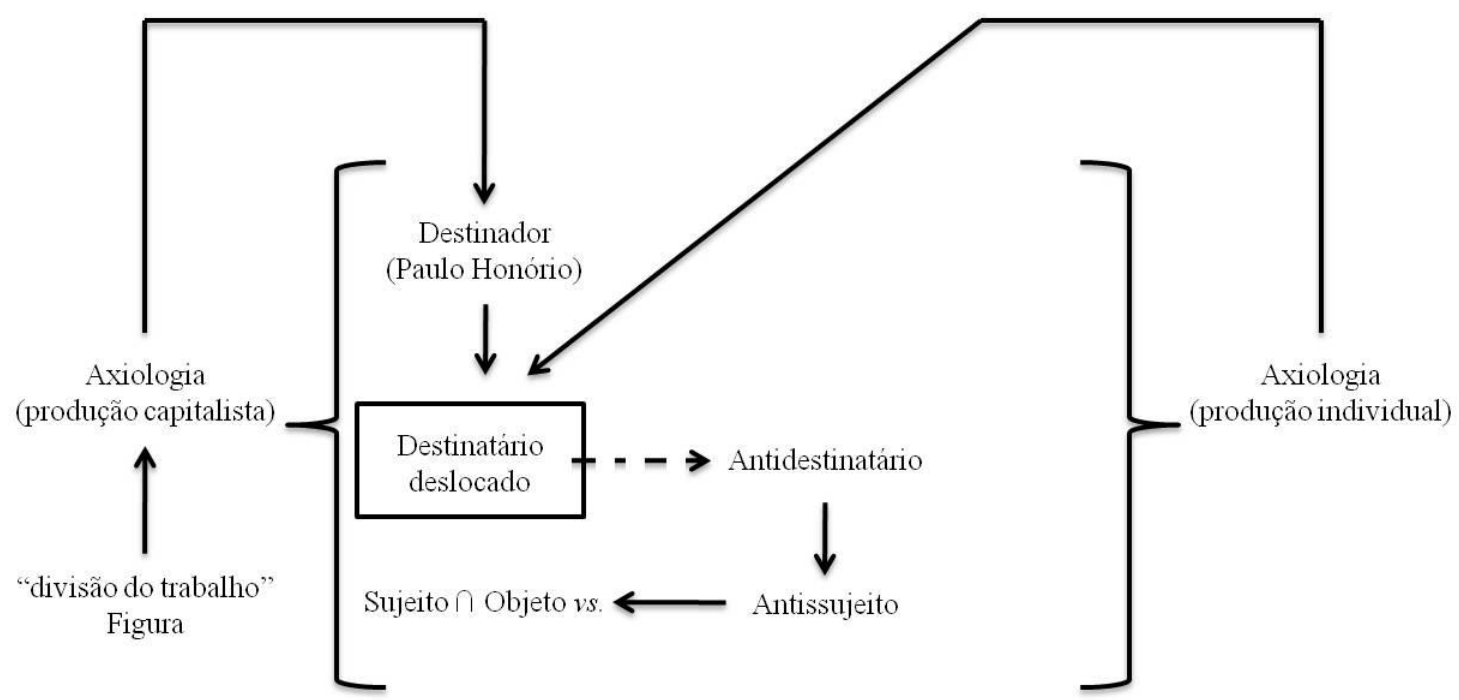

Nesse ponto, o espectro de "antidestinador" surge, exercendo poderes sobre Gondim. Se a "divisão do trabalho" caracteriza-se como "modo de produção coletivo", tal antidestinador, que se corporifica em Gondim como antissujeito, só pode ser seu contrário: o 
ideal romântico de produção artística, o "individualismo" baseado no domínio de outras variações de um código comum, a língua, em sua "originalidade". Escrever como se fala teve interpretação diversa (como veremos na análise da recepção da obra ao longo deste trabalho), mas que, a priori, só pode ser entendida como o mesmo fenômeno de incompreensão ocorrido com aqueles que estão em processo de desenvolvimento e apreensão das noções da linguagem; que ainda não compreenderam as diferenças entre oralidade e escrita e entre "escrever certo" e "escrever bem" artisticamente. O próprio Graciliano fala a respeito disso “Certo é necessário renovar a língua culta, não deixá-la perecer e mumificar-se nos alfarrábios, fixar nela os subsídios que a multidão lhe oferece. Não se conclui daí que devamos tartamudear em livros uma infeliz algaravia indigente, apenas compreensível quando percebemos a entonação e o gesto.” (RAMOS, 1975: p. 272)

Há em Linhas tortas inúmeras referências àqueles que confundem "elaboração estética", proposta pelo Modernismo, com "solecismos", o que Graciliano considerava uma forma de mascarar a incompreensão de que ocorre no processo escrito a absorção de subsídios orais e reelaboração do material oral como escrita, e não o contrário, o que revela um desconhecimento de seu status; e quando conhece, então, revela uma atitude pedante ${ }^{63}$. E o assombro de Paulo Honório é muito diferente do daqueles que comumente dissimulam solecismos, barbarismos, cacofonias etc., aludindo "licença poética" ou uma atitude vanguardista. $\mathrm{O}$ assombro, que não é cólera ou qualquer tipo de manifestação violenta, advém do momento de descoberta, produzindo em seguida um estado de reflexão e uma volta à realidade a que pertence; fora da coletividade em que queria inserir-se pela publicação de obra literária:

Levantei-me e encostei-me à balaustrada para ver de perto o touro limosino que Marciano conduzia ao estábulo. Uma cigarra começou a chiar. A velha Margarida veio vindo pelo paredão do açude, curvada em duas. Na torre da igreja uma coruja piou. Estremeci, pensei em Madalena. Em seguida enchi o cachimbo:

- É o diabo, Gondim. O mingau virou água. Três tentativas falhadas num mês! Beba conhaque, Gondim.

Após manifestação de "assombro" pela descoberta de que ele "não poderia escrever do mesmo modo que falava", e o serenamento, na observação de indivíduos de seu universo cultural e de convívio comum, escuta o pio de coruja na torre da igreja e "estremece". Outra

\footnotetext{
${ }^{63}$ Cf. p. 277 de Linhas Tortas.
} 
reação se nos revela, aqui, associada a Madalena, que ainda não sabemos quem é na primeira leitura, mas que tem enorme valor simbólico, já que, ao som de uma coruja, projeta-se na memória dele a imagem dela: a escrita aqui tem um caráter enigmático para o protagonista; as tentativas falhadas associam-se a Madalena e ao "mau agouro" do pio de coruja. Esses três traços tensivos, na transição do estado de euforia à disforia, representam um feixe de escolhas feitas pelo eu-enunciador; ele não é escolha de Paulo Honório narrador.

Essas reações - "assombro", "serenidade" e "estremecimento" - marcam transitivamente a transformação passional do protagonista (em relação aos fatos ocorridos, mudando as características iniciais de "destinatário" que ele representava, indicando haver um oponente, acima de suas forças, a tal realização). O capítulo 1, assim, marca a transição de estados do protagonista e atualiza o enunciado de estado e da condição de narrador que ele vai assumir (ou seja, o processo capitalista de compor o livro não será assumido, enquanto ideologia, nem pelos coadjuvantes nem pelo protagonista).

O detalhe importante é que o arremate dessas sequências se dá com a expressão da falência total do projeto, "o mingau virou água", e evocação dos três obstáculos ao seu projeto: primeiro, ideológico/político, simbolizado pelo Padre Silvestre; segundo, clássico/tradicional, simbolizado pelo João Nogueira; e o terceiro obstáculo, subjetividade/originalidade, representado pelo Gondim. Todos os três caracterizados pelo domínio individual de elementos comuns a uma classe ou a um estrato social, cujo não domínio das regras e códigos do jogo impede a participação, em termos de performance, em tais círculos. Aqui é fechado um circuito cuja organização geral tem todas as características de uma relação social em que cabe a análise material sociológica. A falência do projeto de escrita tem como origem valores morais e sociológicos. E a partir do piado da coruja ocorre a mudança, para o protagonista, dos motivos da falência: e um deles não poderá ser de outra ordem senão imaterial.

Todos sabem, na segunda leitura, que Madalena é o elemento, na vida do protagonista, que vai "emperrar o dínamo" de São Bernardo. Aqui, de antemão, é o elemento que vai emperrar o dínamo da construção do livro. Antecipemo-nos: Madalena é simbolicamente uma concepção de romance. O chiar da cigarra, que Osman Lins identificou como "poético, convencional, idílico e campestre", produz reações em Madalena (quando ela entrar na história) do mesmo modo que o "elemento sombrio" do piar da coruja na torre da igreja, anunciando uma história trágica, de morte, produz a reação de "estremecimento" em 
Paulo Honório. Semioticamente, as funções sintáticas dessas figuras são a de "manipulador/destinador", também de tematização narrativa e discursiva; e o fato de que elas estejam ligadas a "concepções literárias" ou "convenções" possibilita a crítica desses personagens como "crítica literária" e não "crítica social”, puramente. Este é um detalhe de fundamental importância neste trabalho: Madalena será vista aqui como um "ideal”, não um caráter feminino tão somente, reduzida à simples "sensibilidade feminina".

O que vemos nesse capítulo, portanto, é que Paulo Honório e seus comuns, sua coletividade, não têm uma forma de representação legítima na hierarquia das artes (não formam um coletivo); mas percebeu um modelo de representação que o estereotipou como "pernóstico"; isto é, ele só tem voz pela representação e na representação dos outros, já eivadas de seu poder ideológico como demarcação de conquista do direito à representatividade: "Vá para o inferno, Gondim. Você acanalhou o troço. Está pernóstico, está safado, está idiota. Há lá ninguém que fale dessa forma!" Daí a "ironia” de dizer, mais à frente, "As pessoas que me lerem terão, pois, a bondade de traduzir isto em linguagem literária, se quiserem. Se não quiserem, pouco se perde."

Ou seja, ele não sabe que está propondo o Modernismo, ao julgar sua forma de expressão "não literária" (sempre distinguindo enunciação-enunciada e enunciado: se fizermos a relação metaliterária, aqui, vamos presumir que "Graciliano Ramos" fez a tradução proposta por Paulo Honório porque a realização não corresponde ao processo do narrador). E a sugestão é irônica já que foi exatamente como julgou a linguagem literária, "pernóstica e idiota", provavelmente como a que lhe apresentou Gondim nos dois capítulos que ele caracterizou como "perdidos"; pernóstica e idiota porque provavelmente, sua representação, seu comportamento e sua forma de dizer - lá, enquanto personagem - não correspondiam a seu pressuposto de verossímil ou, talvez, de verdade.

Mas é também indicação de que estamos diante de um processo mental. Os dois capítulos de Gondim conteriam os planos traçados no alpendre da fazenda, a mensagem inicial, o conteúdo inicial imaginado por Paulo Honório e que não coincide, absolutamente, com o início do romance: "Antes de iniciar este livro", porque os inclui numa circunstância em que nenhum deles poderia estar escrevendo. Daí a indecisão do "iniciar", que não sabemos exatamente onde ocorre se não fazemos oposição do estilo de narrar de Paulo Honório e do estilo de escrita/discurso que o objetiva como narrador. 
Há uma mensagem primeira, portanto, nos tais capítulos perdidos. E parece que esses capítulos, nessa forma de representação pernóstica do Gondim, contrapõem-se a essa mensagem primeira imaginada por Paulo Honório. Seria mais ou menos o que Barthes considera "originalidade" nesta ilustração:

\begin{abstract}
Um amigo acaba de perder alguém que ele ama e eu quero dizer-lhe minha compaixão. Ponho-me então a escrever-lhe espontaneamente uma carta. Entretanto, as palavras que encontro não me satisfazem: são "frases": faço "frases" com o mais amoroso de mim mesmo; digo-me então que a mensagem que quero mandar a esse amigo, e que é minha própria compaixão, poderia em suma reduzir-se a uma simples palavra: Condolências. Entretanto, o próprio fim da comunicação a isso se opõe, pois essa seria uma mensagem fria, e por conseguinte inversa, já que o que eu quero comunicar é o próprio calor de minha compaixão. Concluo que para retificar minha mensagem (isto é, em suma, para que ela seja exata) é preciso não só que eu varie, mas ainda que essa variação seja original e como que inventada.(...) Como minha carta de pêsames, todo escrito só se torna obra quando pode variar, em certas condições, uma primeira mensagem (que talvez também seja boa: amo, sofro, compadeço-me). Essas condições de variações são o próprio ser da literatura (...), e assim como minha carta, só podem finalmente ter relação com a originalidade da segunda mensagem. (...) se quero ser menos "falso", é preciso que eu seja mais "original", ou, se se preferir, mais "indireto" (...). A razão está em que essa mensagem primeira, que deveria servir a dizer imediatamente minha pena, essa mensagem pura que desejaria denotar simplesmente o que está em mim, essa mensagem é utópica $(\ldots)^{64}$
\end{abstract}

Ora, não é isso que quer dizer Paulo Honório com "traduzir isso para linguagem literária", isto é, dar uma condição de variabilidade à primeira mensagem que pretende enviar? A relação entre a escrita de Gondim e a mensagem de Paulo Honório é de "originalidade/literatura" (dizer indiretamente) vs. "não originalidade/não literatura" (dizer diretamente). E não é isso que reconhecemos em São Bernardo enquanto realização literária, uma variação estilística da mensagem de Paulo Honório? Parece que Gondim não soube fazer isso sem "ridicularizá-lo", isto é, sem se intrometer com sua "originalidade": "pernóstico" seria para Paulo Honório uma espécie de "enfeite demasiado". Nesse sentido, o que ele procurará será a "não originalidade", isto é, a utopia, uma mensagem pura que denote apenas objetivamente o que pretende: contar sua história. Daí sempre se referir ao plano da escrita no futuro do indicativo ou, como vimos, no futuro do pretérito. E, claro, essa mensagem primeira está no imaginário. Isto é, só a partir do capítulo 3 é que vamos saber o que era essa mensagem primeira. E para sabermos se ela é realmente o que ele mentalizou junto ao Gondim no alpendre da fazenda, a correspondência terá de ocorrer em termos de "não

\footnotetext{
${ }^{64}$ BARTHES, Roland. Crítica e Verdade / São Paulo: Perspectiva, 2003. (Cf. pp. 18 e 19)
} 
originalidade". Só esse traço estilístico nos pode orientar, opondo "linguagem literária" a "não literária" virtualmente, já que o conteúdo da mensagem é algo impossível de se precisar.

\title{
3. O enigma da coruja ou o canto da sereia
}

A memória é a arma dos vencidos.

(BASTOS, 1998: p. 32)

Já no capítulo 2, Paulo Honório conta que, ao ouvir "novo pio de coruja", iniciou a composição, valendo-se de seus próprios recursos, sem se indagar sobre as vantagens que the traria "escrever o livro". Ocorre, neste sentido, uma mudança no ser de Paulo Honório e, consequentemente, em seu fazer, que restitui ao objeto/livro valores pré-discursivos: o livro ou a escrita, para o leitor, tem valor de uso, não poderia ser escrito a quatro mãos, submetido à ética de mercado, sujeitada à reificação/mercantilização.

\begin{abstract}
Abandonei a empresa, mas um dia destes ouvi novo pio de coruja - e iniciei a composição de repente, valendo-me dos meus próprios recursos e sem indagar se isto me traz qualquer vantagem, direta ou indireta. Afinal foi bom privar-me da cooperação de Padre Silvestre, de João Nogueira e do Gondim. Há fatos que eu não revelaria cara a cara, a ninguém. Vou narrá-los porque a obra será publicada com pseudônimo.
\end{abstract}

Nesse parágrafo, dissimula-se uma ruptura impensável: o que ficou no capítulo 1 já são fatos que nenhum autor revelaria por oporem-se ao valor literário autoria/autenticidade de modo geral:

\begin{abstract}
Uma primeira leitura do romance revela um emaranhado de fatos alinhavados aparentemente ao sabor da memória, causando quase a impressão de uma obra descuidada. Alusões iniciais inoportunas, informações e comentários sobre personagens ainda desconhecidas do leitor, considerações e julgamentos do narrador juntam-se à exposição de acontecimentos passados, relatados diretamente pela personagem principal, estabelecendo uma confusa série de dados, de tal forma, que o leitor menos advertido julgaria estar frente ao relato memorialista de um estreante negligente. ${ }^{65}$
\end{abstract}

O nome de Graciliano Ramos, na capa, em termos discursivos tem implicação na disposição do leitor: as palavras de Paschoa Baldassari Guardiano "advertem não se tratar de um estreante negligente", dissimulando que o "Antes de iniciar" tenha sido decisão do eu-

${ }^{65}$ GUARDIANO, Pascha Baldassari. Uma Leitura de São Bernardo: A Exortação Litótica / São Paulo - Franca: Série Teses e Monografias 1, 197(?), datilografada (Cf. p. 30) 
autor e seja, de fato, o início do romance de Paulo Hónório. Isto é, dadas as condições de insucesso do primeiro capítulo e sua impossibilidade de ser apreendido como "verossímil", conforme determinada época, entra em jogo outra possibilidade de reler o que já foi lido: “(...) o fluxo da leitura não se realiza em direção unilateral e irreversível; ao contrário, o que está sendo retido e presentificado possui um efeito retroativo, o presente modificando o passado" (ISER, 1999: vol. 2, p. 22).

Esse efeito do ato de ler possibilita o que virá a seguir, segundo outro tipo de valor. Como se fosse um jogo de "você decide onde começa a história", conforme determinado modo de julgar o valor literário de um texto. Mas o "livro que pretende escrever" Paulo Honório é, em todo tempo, imaginado no futuro, como no trecho acima, com várias chaves indicando onde ele poderia começar. E a nova motivação de "fazer o livro", relacionada a uma figura do cenário, nos leva a outro tipo de tematização e de axiologia: a figura da "coruja" e "seu pio" passam, portanto, a ser "manipulador" do sujeito, em detrimento da primeira figura, "divisão do trabalho", que o caracterizava como "tendo o domínio das ações".

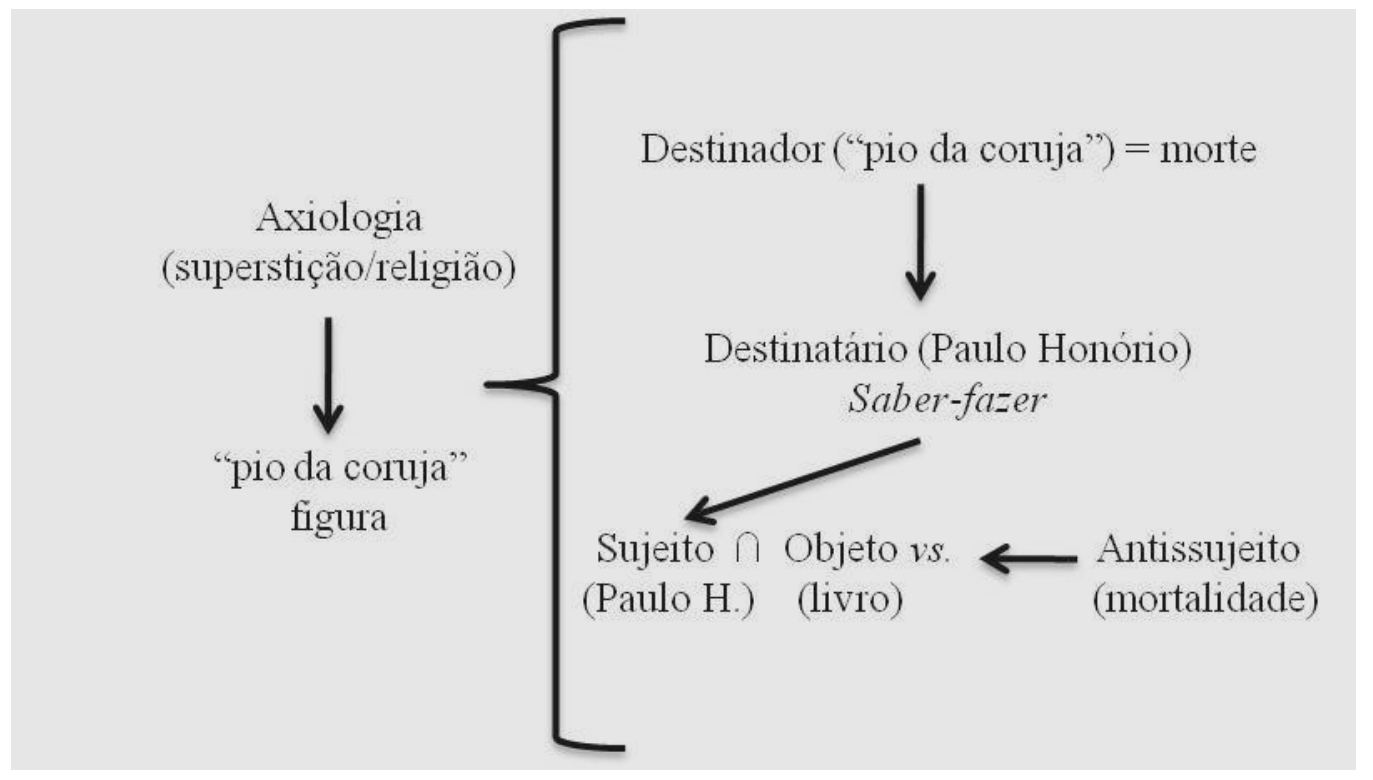

Assim, inaugura-se uma nova perspectiva em relação ao "ser" do protagonista: o da "superstição", abrindo o processo de "comunicar ao leitor", agora, não o que preferiria, a partir do contexto simulado na divisão do trabalho, mas o que pode fazer segundo suas próprias forças: escrever como ele próprio fala. E este é um traço decisivo: corresponde ao "verdadeiro" ser do protagonista, opondo-se ao ser superficial simulado no meio social a 
partir da figura “divisão do trabalho". É o que determina os aspectos de fundo e superfície identificados por Antonio Candido em Ficção e Confissão: o que surge superficialmente como modo de produção capitalista burguês não se confunde com o que aflora do interior ou subsolo do eu protagonista:

\begin{abstract}
Não se trata, evidentemente, do resultado mecânico de certas relações econômicas [o que é projetado pelo narrador e objetivado pela relação do protagonista com os coadjuvantes]. Uma profissão, ou uma ocupação qualquer, é um todo complexo, integrado por certos impulsos e concepções que ultrapassam o objetivo econômico. E êste todo complexo (...) vai tecendo em tôrno da pessoa um casulo de atitudes e convicções que se apresentam, finalmente, como a própria personalidade. Em Paulo Honório, o sentimento de propriedade, mais que o simples instinto de posse, é uma disposição total de espírito, uma atitude complexa diante das coisas. ${ }^{66}$
\end{abstract}

Concordamos com Candido, nesse caso, com a separação que fez de superfície, em cujas relações sociais os elementos externos apresentam-se como personalidade "falsa"; isto é, como algo exterior, conforme alguns personagens, de modo geral, em romances naturalistas. Mas o que vai surgir como interioridade, subsolo do eu do personagem, parecenos não corresponder a "sentimento de propriedade" ou instinto de posse: porque são categorias derivadas do resultado superficial e mecânico das relações econômicas, que Costa Lima e Lafetá analisam sob efeito da reificação. Isto é, transita algo interno no personagem que não pode ser explicado pura e simplesmente com termos ou categorias sociológicas/marxistas, como, por exemplo, falência da empresa. O que interfere no desarranjo do projeto é da ordem do mágico, do azar, que não pode ser avaliado racionalmente tampouco materialmente pelo narrador. Vamos tocar nesses aspectos mais adiante, demonstrando que certas relações entre o protagonista e os coadjuvantes não podem ser pensadas em certos termos ou categorias senão conforme a rede de elementos literários do próprio texto.

Com o surgimento do "pio da coruja", a forma de enunciar caracteriza-se com um "fazer saber" sobre ele mesmo em atitude mental: o que temos em nível de enunciaçãoenunciada é um "escrito por alguém muito diferente de Paulo Honório"; e o que apreendemos dele é apenas fluxo de suas ideias a respeito de como escrever, como proceder e por que fazêlo assim. Até o fim do romance vai-se repetir um eterno "vou escrever assim", "faço um capítulo especial para Madalena”, "Começo declarando que me chamo Paulo Honório” etc.

\footnotetext{
${ }^{66}$ Op. cit. (pp. 21 e 22)
} 
Continuemos. Tenciono contar a minha história. Difícil. Talvez deixe de mencionar particularidades úteis, que me pareçam acessórias e dispensáveis. Também pode ser que, habituado a tratar com matutos, não confie suficientemente na compreensão dos leitores e repita passagens insignificantes. De resto isto vai se arranjando sem nenhuma ordem, como se vê. Não importa. Na opinião dos caboclos que me servem, todo o caminho dá na venda. ${ }^{67}$

Talvez se possa aí interpretar o livro real, de Graciliano Ramos, como o "livro" que Paulo Honório projeta o tempo inteiro para o futuro. Não consideramos essa leitura, já bastante difundida, ilegítima. Contudo, esta não pode ser considerada uma leitura moderna, conformada que está a categorias clássicas de literatura realista, linear, ordenada enquanto convenção. Isto é, Graciliano preserva alguns pontos de contato com essa escola literária porque sabia que "Senhoras idosas, de óculos, ainda lêem o Guarani e choram, mas relativamente aos livros modernos é o que se vê. Falta de público." (RAMOS, 1975: p. 146). Daí o isolamento de Paulo Honório ser forçado pelas expectativas do público. Introduzir aí a iminência de morte ${ }^{68}$ é magnífica solução, pois, muito embora pareça não ser nenhuma novidade em termos de gênero, traz como inovação um meio de representá-la conforme uma mentalidade caracteristicamente regional, fazendo da palavra o valor da troca simbólica: é do seu valor intrínseco que se valerá o narrador, não do valor de mercado.

O protagonista, assim, deixa de ser elemento ativo - fundamentalmente o era enquanto suas motivações de escrever provinham da figura "divisão do trabalho", pela característica de "manipulador" -, passando a elemento "passivo", individualizando-se, em sua subjetividade, com característica de "manipulado". Para o leitor, aqui começa uma nova aventura: conhecer por dentro um indivíduo presunçoso, a princípio; em seguida "estremecido" pela iminência da morte, o núcleo do romance.

Tanto "pio de coruja" como "canto de sereia" e até mesmo "grasnar de corvo" são figuras literárias, cumprem definitivamente uma função metafórica: a memória é o único meio de sobrevivência do ente social em sua coletividade. Lembremo-nos de Ulisses ao manietar-se no mastro de seu barco: ouvia ele das sereias sua própria aventura, dolorosa; Paulo Honório ouve sua história no pio da coruja, metáfora da memória da "morte" como previsão do futuro. A associação à escrita é associação a Madalena, que se torna uma espécie de musa agourenta, na figura da coruja:

\footnotetext{
${ }^{67}$ Cf. cap. 2, p. 10. Esse tempo verbal (presente + infinitivo) pode ser sintetizada em "contarei".

68 "No sistema hieróglifo, a coruja simboliza a morte, a noite, o frio e a passividade". Cf. CIRLOT, JuanEduardo. Dicionário de Símbolos, S. Paulo: Moraes, 1984. Outros significados como “(...) entre os astecas, ela é animal simbólico do deus dos infernos" encontram-se em CHAVALIER, Jean. Dicionário de Símbolos: mitos, sonhos, costumes, gestos, formas, figuras, cores, números; Rio de janeiro: José Olímpio, 1999.
} 
Ao narrar o processo da escritura, começa falando do incômodo do pio da coruja que o obriga a retomar a escrita de sua história, agora por sua própria conta. Escreve-a, incomodado pelo símbolo que o remete sempre à lembrança de Madalena. Essa passagem faz-nos pensar na coruja de Minerva, cujo trabalho é sempre noturno, apagadas as luzes do dia. Faz-nos pensar no trabalho da consciência e, portanto, no reino do conhecimento em que a consciência experimenta a si mesma ${ }^{69}$.

Como dissemos, algumas categorias parecem não comportar toda a complexidade do narrador. O termo "consciência" racionaliza o "irracional": "azar", "mau agouro", "maldição" etc. distanciam-se completamente das visadas psicológicas burguesas da "consciência que experimenta a si mesma", substituindo os traços folclóricos do sujeito. Pelo contrário, entramos no reino da inconsciência revelada por meio da superstição ou do meio místico. Pereira perscrutou no significado, que a figura da coruja the produz, o veio romântico de São Bernardo, que é uma possibilidade, mas não a totalidade absoluta dos traços que compõem o caráter do protagonista. A coruja surge, no passado do protagonista, da inconsciência, conforme o imaginário popular - o que remonta à Idade Média ou à tradição hermenêutica como superstição de que "o pio dela" perto de casa significaria "a morte de alguém", isto é, a coruja "fala" com ele e antecipa eventos tidos como misteriosos: "O menor sintoma da natureza seria também o signo dos movimentos da natureza inteira. Um vento, o grito de um pássaro, a cor de um lagarto assinalariam, ao homem que conhecesse a linguagem dos signos, transformações que ele podia prever no mundo natural."${ }^{, 70}$

Não há explicação aí, por isso nenhuma consciência, porque compartilha da mesma natureza do mito e da lenda: não é o sentimento de culpa que se tematizará; mas o tema do erro e da perseguição de sua causa. Não é a lembrança de sua culpa que o leva à empreitada da escrita; é o "não saber onde ocorreu o erro" que o inquieta e o "obriga" a escrever, como meio de saber, pela rememoração, por que está sob o prenúncio da morte que a coruja transmite. Momentos antes de Madalena suicidar-se, Paulo Honório sobe à torre da igreja com Marciano, que mata as corujas que ali se aninharam; ao descer de lá, diz que está, então, "em paz com Deus e com os homens". Não é à toa que, ao ouvi-la no final do capítulo 1, Paulo Honório se dirige ao Gondim dizendo: "É o diabo, Gondim".

A interpretação de João Pereira é válida, mas a noção de consciência perscrutada na figura da coruja supõe o sertanejo num nível de análise muito além de sua condição sócio-

\footnotetext{
${ }^{69}$ PINTO, João Pereira. Diálogo entre Literatura e Filosofia em São Bernardo de Graciliano Ramos / Londrina: Ed. UEL, 1998. (Cf. p. 65)

${ }^{70}$ DEL PRIORE, Mary. Esquecidos por Deus. Monstros no Mundo Europeu e Ibero-Americano: Uma história dos Monstros do Velho e do Novo Mundo (Séculos XVI-XVIII) / São Paulo: Cia. das Letras, 2000. (Cf. p. 99)
} 
cultural (a consciência burguesa remete a um diagnóstico de si mesma em forma de arrependimento ou culpa; o que surgirá, com a figura do pio da coruja, é previsão do mal exterior ao indivíduo e do qual ele participou como cúmplice sem saber, o que humaniza e regionaliza categoricamente o ser sertanejo). E é este o ponto fundamental de entendimento de sua noção de "linguagem". Enquanto do ponto de vista da análise essa figura é apenas função na narrativa (do nosso ponto de vista, uma tematização de convenção literária), do ponto de vista do protagonista ela é alegoria do mundo físico religioso/supersticioso. Isto é, ela remete à tradição, no mínimo, medieval e jesuítica de ler no mundo a história escrita por Deus:

A rigor (...) não se pode falar simplesmente de $a$ alegoria, porque há duas: uma alegoria construtiva ou retórica, uma alegoria interpretativa ou hermenêutica. Elas são complementares, podendo-se dizer que simetricamente inversas: como expressão, a alegoria dos poetas é uma maneira de falar; como interpretação, a alegoria dos teólogos é um modo de entender. ${ }^{71}$

Assim, a alegoria dos poetas corresponde, neste trabalho, ao modo como vemos construídas a narrativa e suas figuras - "o pio da coruja", o "chiar da cigarra" etc. -, mas de uma maneira que talvez a noção nem mesmo tenha tanto alcance aplicativo, segundo o padrão de uma construção mimética análoga a um conceito, uma ideia, a fim de exemplificar ou de dar a conhecer algo. Tendo em mente essa limitação aplicativa, a alegoria dos teólogos, hermenêutica, corresponde-se com o modo como Paulo Honório lê ou ouve "falar" a própria natureza ou as criaturas do mundo. A linguagem para ele é substância. E é curioso como essa noção ou modo de ver caracteriza Paulo Honório. É o próprio fundamento dessa linguagem substancialista, implicada nas reações de "estremecimentos" e alusões de "azar", que o caracteriza finalmente como homem do sertão, como poderia ser na realidade o sertanejo, em seus costumes, e também tal qual poderia ser a figura da coruja piando na torre da igreja enquanto alegoria. Ela é seu instrumento interpretativo comum, que, adequadamente, substitui as noções de língua do homem moderno, alfabetizado ou "civilizado", burguês e racionalista: “(...) a alegoria é uma técnica de interpretação. Decifra significações tidas como verdades sagradas, ocultas na natureza sob a aparência das coisas e também na linguagem figurada dos textos das Escrituras, que revela um 'sentido espiritual'”. (HANSEN, 1986: p. 43)

\footnotetext{
${ }^{71}$ HANSEN, João Adolfo. Alegoria: Construção e Interpretação da Metáfora / São Paulo: Atual, 1986.
} 
Mas não só o sagrado como o profano é decifrado. É preciso considerar a ambivalência "bem/mal". E muito embora a imprecação "É o diabo!" não descreva um Paulo Honório demasiado religioso, ela o revela por trair-se: “(...) consiste em invocar nomeadamente o anti-Deus, o Diabo, pela exclamação 'Diabo!'. A necessidade de transgredir o interdito, profundamente dissimulada no inconsciente, encontra uma saída, numa jaculação brutal, arrancada pela intensidade do sentimento, e que se realiza achincalhando o divino."72

Daí, em detrimento do sentido utilitário de "escrever um livro", configurar-se um novo sentido, em dimensões fugidias, e que, para captá-lo, o leitor terá que percorrer todos os processos, significados e acontecimentos "futuros" que serão narrados, isto é: ir à busca do romance habitual, embora, para que compreenda o "sentido da vida" do protagonista, tenha que compactuar com seu modo de apreendê-la, um dos maiores obstáculos produzidos por São Bernardo em função de sugerir uma espécie de "cumplicidade" com a palavra de um jagunço/coronel.

Ao leitor atento não passa despercebido o fato de que os dois primeiros capítulos, sendo de atualização, da vida presente do narrador, revelam sobretudo a encenação do impasse do narrar e a necessidade de ser firmado um pacto entre narrador e leitor. (...) A decisão de Paulo Honório, segundo a qual a literatura deve ser escrita como se fala, é decisiva para o pacto que ele firma com sua própria narrativa e através desta com o leitor. Através dela ele pretende convencionar sua sinceridade, simplicidade e o tom confessional, a fim de que sua escrita encontre eco imediato no bom senso do homem comum. (FACIOLI, 1993: p. 52)

Procurando dar conta desses dois primeiros capítulos, Facioli assume uma perspectiva diferente da que verificamos até agora na estrutura narrativa do romance, por não ter incluído nas estratégias discursivas o próprio enunciado como um jogo de inversões, ou seja, tomando a enunciação como condição de transformar em discurso a estrutura narrativa. Ou seja, Facioli não observa, na transição dos estados de euforia à disforia, o encerramento, no capítulo 1, do circuito de análise material, racional, da falência do projeto e a abertura de um novo circuito, em que a falha será interpretada como uma espécie de maldição. Está, porém, coberto de razão quando diz que esses capítulos são de atualização do estado. Mas a ideia de que a língua falada é o padrão linguístico adequado, na mentalidade de Paulo Honório, como veículo da literatura, é discutível, por não ser nem a realização prática nem um valor literário oposto ao dos protagonistas.

\footnotetext{
72 BENVENISTE, Émile. “A Blasfêmia e A Eufemia” In: Problemas de Linguística Geral II / Trad. Eduardo Guimarães [et alii]; Campinas, S.P: Pontes, 1989. (Cf. p. 262)
} 
Se tal decisão, tomada por Paulo Honório, fosse possível, ter-se-ia que levar em conta o pressuposto atual de que a linguagem coloquial é um componente estético na mentalidade de Paulo Honório, usando-a com o fim de persuadir o destinatário de que ela é a prova de sua sinceridade e simplicidade em vez de ser sua única possibilidade de realização escrita.

A ligação direta que Facioli faz da atitude de Paulo Honório com o "senso comum do leitor moderno" é plenamente legitimada na atualidade, em termos de recepção, como um método de análise e interpretação; mas não se pode estendê-lo temporalmente a todo o processo histórico, desde a publicação de São Bernardo à atualidade. O fundamental em sua interpretação é que evidencia que ocorre, por meio daqueles capítulos, um pacto com o leitor, renovando-se à medida que as acepções dos elementos literários se transformam no tempo e na interação, em nível de enunciação, entre texto e leitor. A cada novo contexto de leitura, as interpretações se renovam. E é esta uma das provas da perenidade de leituras que alcançou São Bernardo.

Não há decisão, por isso, no sentido de uma escolha estética, ou retórica, relacionada a certo público, mas constrangimento pela "fala da coruja" em termos narratológicos. E a inversão, na narrativa, dos valores atraentes para o protagonista insinua o sentido oposto dos valores atraentes para o leitor, conforme as expectativas se processam em determinados contextos. O que Valentim Facioli caracterizou como construção de "pacto" é fundamental para a compreensão do personagem: o termo explicita-se por um tipo de relação completamente diferente da relação moderna capitalista de "contrato" e remete a uma organização social que não se deixa analisar com muita facilidade a partir de certas categorias exteriores a ela.

Baudrillard se refere a determinadas trocas simbólicas em que os objetos despidos do valor mercantil apresentariam características transcendentes aos valores estabelecidos por operações do mercado. No caso, "a língua falada", despida do valor de troca do primeiro capítulo, torna-se o "objeto simbólico" da troca:

(...) pois quer uma coisa "não valha nada", quer ela "não tenha preço", em ambos os casos estamos no inapreciável, no sentido radical da expressão. A partir daí, a troca que se possa fazer com elas se opera em bases que não dependem mais do contrato - como se dá habilmente no sistema de valor - e sim do pacto. Há uma diferença profunda entre o contrato, que é uma convenção abstrata entre dois termos, dois indivíduos, e o pacto, que é uma relação dual e cúmplice. ${ }^{73}$

\footnotetext{
${ }^{73}$ BAUDRILLARD, Jean. Senhas. Rio de Janeiro: DIFEL, 2001. (Cf. pp. 14 e 15)
} 
Deixemos para os lances da história contada por Paulo Honório, de sua infância em diante, a exploração do que se revela contrário à aplicação direta, sem mais mediações, de categorias sociológicas/marxistas. Apenas se mantenha aqui a ideia de que, para alguns leitores, compactuar com Paulo Honório pelo contrato narrativo seria assinar com ele um pacto de cumplicidade, daí certa recusa sem hesitação de seus métodos e de sua figura etc. E enquanto Facioli compreende "a escolha da língua falada" como uma forma de mascarar "o monopólio da linguagem" e manutenção do protocolo da propriedade privada em termos simbólicos narrativos, há, por outro lado, também a possibilidade de serem percebidas - sob esse aspecto de superfície - que a língua falada apenas envolve, como um manto, relações de fundo eventualmente fora do padrão de comportamento burguês ou capitalista.

Isto é, Valentim Facioli faz uma leitura de superfície enunciativa, que pode talvez corresponder a um traço do autor Graciliano Ramos; mas não ao narrador Paulo Honório por não comportar a ideia de "língua falada", atualmente compreendida em literatura como uma modalidade de pensamento dele, internamente, no romance. Ou seja, Valentim, como qualquer outro leitor moderno ou leitor da atualidade, "preenche" os "termos" "escrever como se fala" com valores atuais de convenção literária e valor estético como estratégia retórica.

Voltemos às articulações em nível fundamental ou profundo. Nos primeiros parágrafos de São Bernardo, o deslocamento do sujeito rumo ao seu objeto (entre a descontinuidade de um estado para a parada da descontinuidade) caracteriza-se como início de um "bem-estar" (euforia), cuja representação sintática seria a de que "os colaboradores" (sujeito 2) lhe dariam a posse (conjunção) de um objeto que lhe é atraente. 


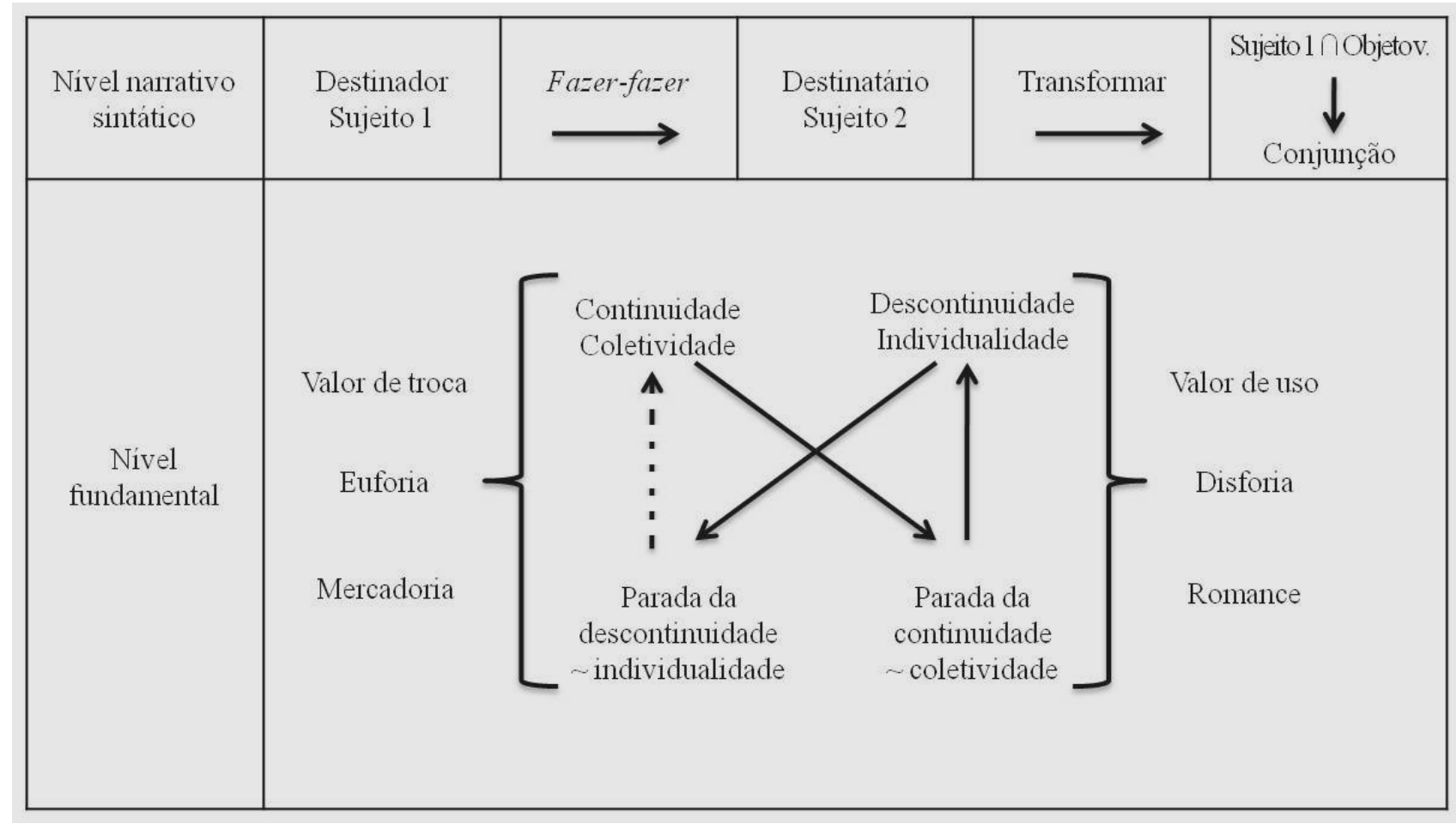

Como vimos, os colaboradores resistem ao projeto. E, no capítulo 2, após ouvir novo pio de coruja, o reinicia, a partir de suas próprias possibilidades, deixando de lado a ideia de "lucro" ou "qualquer vantagem" do tipo anteriormente imaginado.

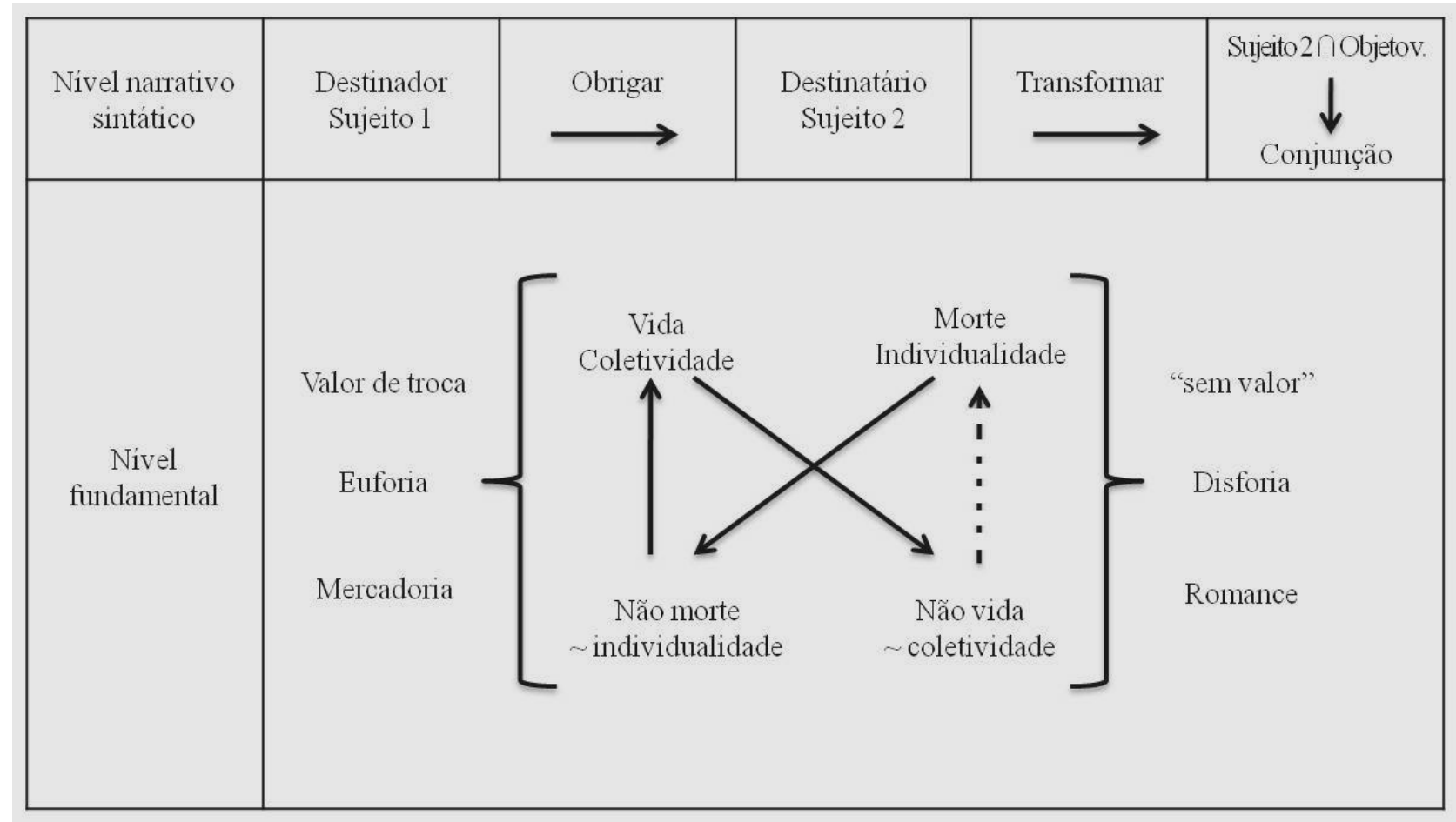


É interessante notar que sua escolha por força se caracteriza pela negação de suas convicções iniciais: esse isolamento pela individualidade, que lhe impõe a não colaboração dos coadjuvantes, retira-o de uma esfera em que ele era dominante e o põe na do dominado; daquela em que se tem o romance como mercadoria, valor de troca, para aquela em que se tem apenas valor de uso (uma hipótese que ainda pode ser descartada, já que "valor de uso" participa de um universo em que talvez não seja adequado nenhum tipo de valor mercantil, em que a troca simbólica entre narrador e narratário se estabeleça por outros paradigmas).

\begin{abstract}
A escolha de valores corresponde a uma primeira decisão do sujeito da enunciação, quanto ao discurso que será produzido. A atualização dos valores ocorre, como visto, no enunciado de estado, em que o valor é investido no objeto e relacionado, por disjunção ou conjunção, com o sujeito. Só assim, inscrito na estrutura sintática, o valor se torna legível e faz do objeto um objeto-valor (BARROS, 2003: pp. 45, 46).
\end{abstract}

Essa inversão das posições ocupadas é que convenciona um contato com o leitor ou seu distanciamento, pelas condições discursivas, e insere um novo valor no objeto/livro em termos de narrativa que pode ser às vezes inapreciável como troca simbólica: enquanto "livro" determinado por valor de mercado, o objeto se afastaria da predisposição do leitor; enquanto antivalor do valor mercantil, o livro ganha contornos mais nítidos de "revelação" de um sentido oculto e exclusivo da individualidade humana na linguagem. O leitor fictício, portanto, está inscrito na estrutura sintática do romance.

\footnotetext{
(...) o leitor do romance [convencional] procura realmente homens nos quais possa ler "o sentido da vida". Ele precisa, portanto, estar seguro de antemão, de um modo ou outro, de que participará de sua morte. Se necessário, a morte no sentido figurado: o fim do romance. Mas de preferência a morte verdadeira. Como esses personagens anunciam que a morte já está à sua espera, uma morte determinada, num lugar determinado? É dessa questão que se alimenta o interesse absorvente do leitor. (BENJAMIN, 1994: p.214)
}

De fato "a motivação de Paulo Honório" não é impulsionada pela "língua falada", como pareceu a Facioli: é motivada pela iminência da "morte" prenunciada pelo "pio da coruja", que é um elemento da estrutura narrativa e que desfez o sentido da vida ou o modo como a viveu o personagem quando faz a descoberta assombrosa de que ele não participava totalmente do universo dos letrados. Facioli interpretou esses capítulos de outro ponto de vista, sem levar em conta as figuras retóricas que os permeiam e sem ressaltar que, para o protagonista, tal decisão não lhe era atraente, mas penosa - vide os sintomas de disforia.

Assim a figura da "coruja" e o sentido de seu "pio", que não são simplesmente uma imagem do mundo real utilizada pelo autor como estampa de cenas ou cenários da história, 
remetem a um mundo, dentro do protagonista, meio obscuro, do qual preferiria não falar inicialmente, mas que será forçado a contar. Desempenhando papel fundamental para o desfecho do significado do romance, é alegoria da fala da natureza ou do sobrenatural, uma hipótese do desnorteio "profissional e amoroso"; o pio funciona como forma da expressão que exprime o sentido ocultado nas reações de Paulo Honório: "Na torre da igreja uma coruja piou. Estremeci, pensei em Madalena". E é com essa função que o "pio da coruja" pontua toda a narrativa e revela outro indivíduo: arcaico, patriarcal, escravocrata, sob o superficialmente capitalista e moderno, indivíduo materialista tão somente.

Embora Abel Barros Baptista tenha mencionado também "o pio da coruja" como desencadeador dos novos rumos da ideia de "compor um livro", não o vê desempenhado nenhuma função sintática. Ora, o caso é que, praticamente, poucos críticos parecem ter analisado esse detalhe, entre eles Osman Lins, Abel Barros Baptista e João Pereira Pinto. Tratando-se, o segundo, de um crítico estrangeiro, não nos surpreende o desconhecimento do significado do "pio da coruja" num quintal de casa brasileira qualquer, ou melhor, no contexto histórico e folclórico brasileiro, já que na Europa é o "grasnar do corvo" que cumpre essa função. Assim o crítico português vê a figura do "pio da coruja" como algo que "Aparece no final do primeiro capítulo, associado ao termo da colaboração de Gondim, e ressurge no começo do segundo, associado ao desencadear repentino da escrita. (...) não existe nem decisão nem finalidade.” (BAPTISTA, 2005: pp. 105 e 106)

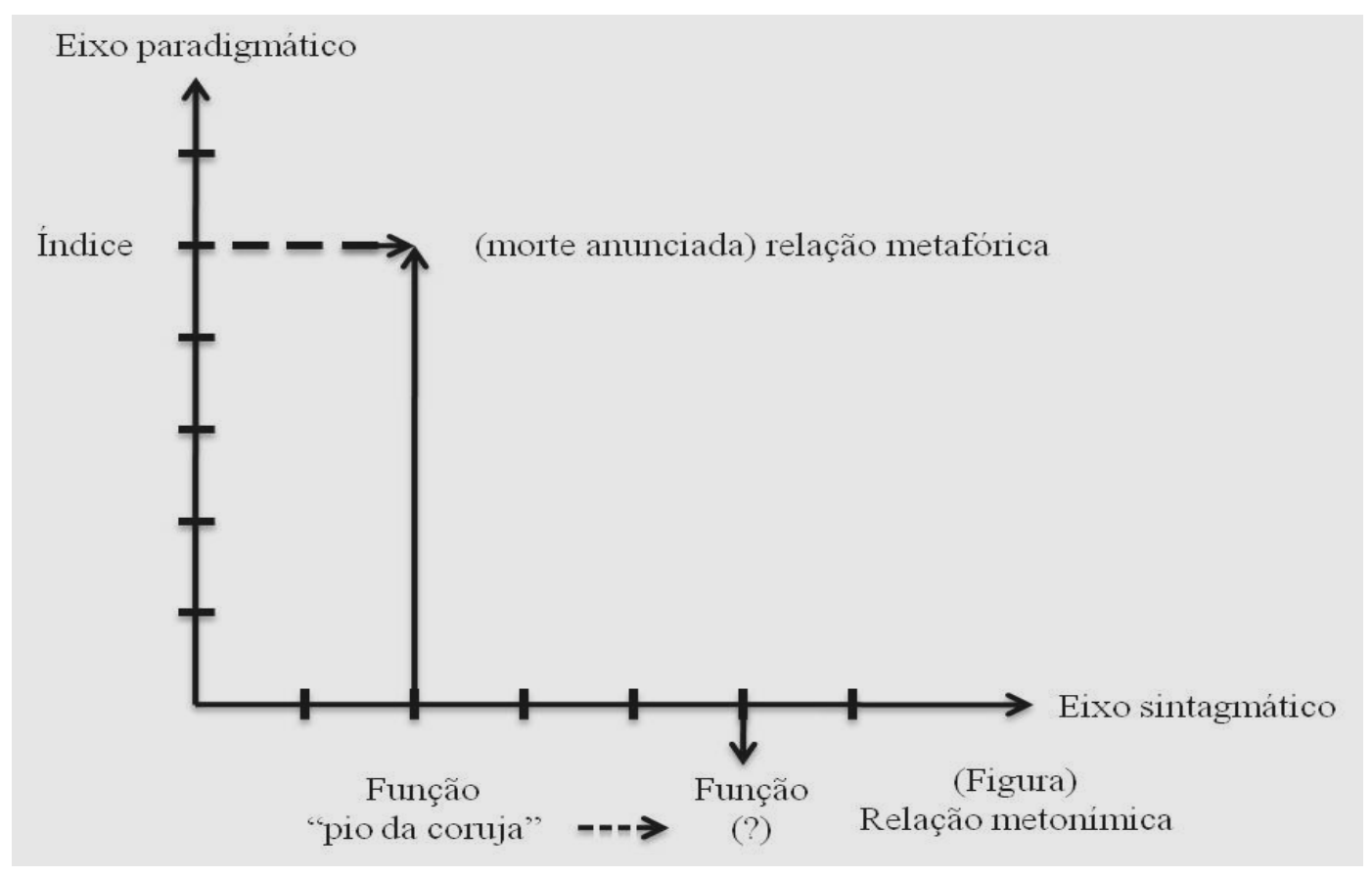


Ora, associa-se ao Gondim, porque há uma primeira morte/perda: o enfático "não pode" do colaborador significou a desilusão de pertencer àquela esfera de relações da qual acreditava participar, conforme o meio de valores capitalistas parecia lhe indicar; a negação revela não haver, em termos de linguagem e ideologia, "cumplicidade" entre eles. Essa primeira morte corresponde, portanto, à do ente social ou superficial das relações burguesas: quando lança o olhar a seu redor, vê a velha Margarida e Marciano, vê sua condição real, em que não há um contrato social (que pode ser rompido ou modificado), mas um pacto irreversível. Quanto à associação ao nome de Madalena, é uma indicação futura, mas que já se insinua ao leitor como trama própria do romance romântico, em que ela já está morta. A novidade é que a figura da coruja, regionalizada, agrega ao caráter enigmático da linguagem o enigma Madalena.

\begin{abstract}
Tudo isso, entretanto, surge como num quadro, em silêncio. Rompe afinal o silêncio uma indicação campestre, idílica e até certo ponto convencional: "Uma cigarra começou a chiar." Por que, precisamente aí, canta esta cigarra insólita? É que o verdadeiro arremate do capítulo aproxima-se: "Na torre da igreja, uma coruja piou. Estremeci, pensei em Madalena." Uma voz funesta, o pio da coruja, vai fazer com que Paulo Honório estremeça e pense em Madalena. A solução, de uma grande economia, é espantosamente eficaz: anuncia-se, com absoluta clareza, uma história sombria, envolvendo essa Madalena cujo nome surge pela primeira vez na obra (...) (LINS, 1978: p. 194)
\end{abstract}

Edgar Allan Poe já havia recorrido a recurso similar em seu poema "O corvo". Não sabemos textualmente se Graciliano tinha ou não conhecimento do ensaio de Poe a respeito do poema, mas o mesmo recurso foi utilizado em São Bernardo. Também em Quincas Borba, de Machado de Assis, no capítulo 37, ao anunciar o prenúncio para Tonica: "Tonica sentia grasnar o velho corvo da desesperança. Quoth the raven: NEVER MORE". Essa figura é um elemento completamente literário - só há como chegar à função da figura do corvo e seu grasnar mediante a literatura e é evidente que Tonica não ouviu corvo algum: o narrador demonstra conhecer não só a literatura como sua estrutura convencional - e ele vai dar um desfecho completamente antirromântico, jocoso e cômico à condição de noiva de Tonica: o grasnar do corvo vai recair precisamente sobre seu noivo. Mas Poe nos conta que

(...) já havia chegado à ideia de um Corvo, a ave do mau agouro, repetindo monotonamente a expressão "Nunca mais", na conclusão de cada instância de um poema de tom melancólico e extensão de cerca de cem linhas. (...) perguntei-me: "De todos os temas melancólicos, qual, segundo a compreensão universal da humanidade, é o mais melancólico?" A Morte - foi a resposta evidente. "E quando", insisti, "esse mais melancólico dos temas se torna o mais poético?" (...) a morte, pois, de 
uma bela mulher é, inquestionavelmente, o tema mais poético do mundo e, igualmente, a boca mais capaz de desenvolver tal tema é a de um amante despojado de seu amor". ${ }^{74}$

Abel Barros Baptista e Valentim Facioli tomam outro rumo ao não encontrarem a correspondência literária da função do "pio da coruja" relacionada ao romantismo em termos de convenção literária; do que um escritor como Machado não poderia deixar de ter zombado, ao inverter o prenúncio, o que torna a situação de Tonica patética, mais do que se ela tivesse morrido no lugar do noivo.

Decorre desse detalhe, porém, a atração inigualável de São Bernardo sobre o interesse do leitor em desvendar o mistério que o envolve sucessivamente a cada capítulo. Se a função do grasnar do corvo ou do pio da coruja é a mesma em termos de convenção, acrescente-se a inovação de Graciliano, configurando-a como musa, sereia, relativa à memória no "piar", dando-lhe uma nova referência estética, regionalizando-a conforme o folclore brasileiro e acentuando o grau de tragicidade da história. Sem análise deste detalhe, corre-se o risco de analisar apenas uma face do romance, desencadeada pela morte de Madalena, e não se perceber o embate entre "a poesia idílica, campestre", simbolizada pelo chiar da cigarra, e a "voz funesta da morte", simbolizada na figura da coruja (ambas com função sintática de destinador). Sem esse detalhe, São Bernardo seria apenas mais um romance cuja sequência seguiria a via romântica e nem mesmo poderia se falar em realismo aí, tamanha ligação teria ele com o Romantismo. Tal desvio leva inclusive Álvaro Lins a considerar São Bernardo não um romance, mas uma novela. Ele só vê matéria literária, própria do romance romântico, após o casamento de Paulo Honório, descartando até mesmo capítulos inteiros.

Na enunciação, vemos já de entrada as oposições sinalizando uma motivação presente em tensão com a motivação do passado: no presente o protagonista declara: “(...) a minha ignorância é completa. E não vou, está claro, aos 50 anos, munir-me de noções que não obtive na mocidade"; isto é, aquele capital cultural que o privou do círculo e da colaboração dos intelectuais. E continua dizendo, em relação a noções de quais não se apossou, que seu fito na vida era apossar-se das terras de São Bernardo, opondo-se ao "novo fito": escrever um romance. Mas “para que escrever?” Quais as relações da escrita com o "pio da coruja”? Sobretudo, quais relações haveria entre essas questões e o alegado fato da "inverossimilhança"?

\footnotetext{
${ }^{74}$ POE, Edgar Allan. Poemas e Ensaios / São Paulo: Globo. 1999. (Cf. p. 107)
} 


\title{
4. A recepção crítica de São Bernardo pós-anos 50
}

\author{
Ocupado com esses empreendimentos, não alcancei a ciência de João Nogueira nem as tolices do \\ Gondim. As pessoas que me lerem terão a bondade de traduzir isto em linguagem literária, se \\ quiserem. Se não quiserem, pouco se perde. Não pretendo bancar escritor. É tarde para mudar de \\ profissão. E o pequeno que ali está chorando necessita que o encaminhe e lhe ensine as regras de bem \\ viver. \\ - Então pra que escreve? \\ - Sei lá. \\ O pior é que já estraguei diversas folhas e não principiei ${ }^{75}$. \\ - Maria das Dores, outra xícara de café. \\ Dois capítulos perdidos. Talvez não fosse mau aproveitar os do Gondim, depois de expurgados. (Cf. \\ p. 11)
}

Ao declarar que não pode acumular um "capital cultural" cuja circulação não estava no sertão, Paulo Honório separa o trabalhador manual, ocupado com o plantio, com a pecuária etc., daquele que desenvolve o trabalho intelectual, expresso nos termos "ciência de João Nogueira" e "tolices do Gondim". Isto é, ao trabalhador braçal não há possibilidade de desenvolver-se intelectualmente, já que, produzindo, não tem disponível para si mesmo tempo hábil para isso (coisa que Paulo Honório resolve parcialmente, sendo semialfabetizado durante os três anos e nove meses de prisão; considerando, aqui, "semialfabetização" o fato de que ele ali aprendera a ler, não a escrever, que não é um processo análogo).

Daí o dilema de "encaminhar e ensinar as regras de bem viver ao filho": Paulo Honório está dividido - sabemos que ele ludibriou Padilha porque este, encaminhado pelo pai para ser bacharel, liquidou o negócio, a fazenda, pela inexperiência com a terra - entre duas atividades que se excluem, uma exigindo "ócio", outra, a negação do ócio. Evidentemente compreende sua posição de "semialfabetizado" correlacionada à posição de trabalhador braçal, aparentemente, como uma tomada de consciência de classe. A questão é que, todos sabemos, seu fito na vida, anterior ao projeto de escrever seu livro, era conquistar, cultivar São Bernardo e dar um herdeiro a ela. Por que o apego a essa fazenda, exatamente, e a preocupação de manter sua posse através do herdeiro, esse que está ao seu lado chorando?

\footnotetext{
75 “É preciso notar que o segundo capítulo começa afirmando que Paulo Honório já começou a escrever o livro e acaba afirmando que Paulo Honório ainda não começou a escrever o livro, ou seja, difere o começo, situa-o num futuro imediato, a fim de dizer que o começo, afinal, tinha ocorrido num passado imediato, num 'dia destes"'. (BAPTISTA, 2005: p. 151) O que Baptista identifica, do nosso ponto de vista, decorre de que "(...) multiplicidade das interpretações de um texto indica que estas seleções subjetivas não são idênticas, mas passíveis de compreensão intersubjetiva, uma vez que representam tentativas de otimizar a mesma rede relacional.” (ISER, 1999: vol. 1 p. 27)
} 
Acossado, depois, pela superstição, pelo surgimento do pio da coruja, simbolicamente a "morte que se anuncia", como preparar esse herdeiro? Ora, em sua ausência, caso morresse, haveria a memória escrita, que cumpriria a função de adverti-lo sobre "as regras de bem viver"; além de desvendar o mistério, o motivo da perseguição empreendida por Deus ou pelo Diabo na fala da coruja. O drama, portanto, está na impossibilidade de escrever também. E Álvaro Lins, em artigo de 1947, diz que "Os primeiros capítulos se lançam em várias direções, como se o romancista não estivesse ainda no domínio da linha central do desenvolvimento dramático" ${ }^{, 76}$.

O parecer de Lins, além de dar pistas de que há várias entradas e saídas na narrativa, sugere esse desnorteio do protagonista, sua labuta numa atividade nova. Mas isso não parece ocorrer com o capítulo 1, verificando-se só a partir do capítulo 2. Continua dizendo que "Há mesmo alguns trechos que parecem enxertados, podendo figurar ou não no conjunto, indiferentemente, como o capítulo 7, com a história independente de 'seu' Ribeiro." Enfim, resume a apreensão que faz da leitura: "Como ficção, rigorosamente, o livro só se afirma e define a partir do casamento de Paulo Honório com Madalena" (LINS, 1968: p. 79). Afinal, não é à toa que segue este raciocínio:

\begin{abstract}
O principal defeito de São Bernardo já tem sido apontado mais de uma vez: é a inverossimilhança de Paulo Honório como narrador, é o contraste entre o livro e seu imaginário escritor (...) Uma novela de tanta densidade psicológica, elaborada com tantos requintes de arte literária, não suporta o artifício de ser apresentada como escrita por um personagem primário, rústico, grosseiro, ordinário, da espécie de Paulo Honório. ${ }^{77}$
\end{abstract}

Apesar de considerar apenas o viés romântico da narrativa, endossa a ideia de que Paulo Honório "escreveu o livro de Graciliano": dá um salto, não analisa nenhuma linha daqueles capítulos que apontam para várias direções, mas retém firme, deles, a ideia da escrita, na ficção, como fundamento da categoria narrativa de "autor-fictício" e sua "origem social" por tê-lo rebaixado a "primário, rústico, grosseiro, ordinário", o que significa que aqueles capítulos não foram inúteis em função de produzir empatia/antipatia. Por isso Álvaro Lins considera o narrador de Vidas Secas o próprio autor: “(...) sua primeira obra de ficção em que a pessoa encarregada de narrar a história não é um personagem, mas o próprio romancista" (LINS, 1968: p. 82). Tal confusão advém certamente da forma de apreciar o romance, característica da segunda metade do século XIX, estendendo-se até a atualidade,

\footnotetext{
${ }^{76}$ LINS, Álvaro. O Romance Brasileiro Contemporâneo / Rio de Janeiro: Edições de Ouro, 1968. (Cf. p. 78) ${ }^{77}$ Idem.
} 
baseada em processos de investigação literária concentrada biograficamente na figura do autor e no critério de maior e menor grau de realismo segundo o foco narrativo.

Nessa confusão entre autor e “autor ficcional”, para Candido, está o próprio fundamento da obra literária. Ainda que não diga isso, nos dá a entender conforme o título de seu trabalho "Ficção e Confissão". Isto é, não desfaz a ambiguidade, mas a toma como aspecto literário inerente ao texto artístico. É o primeiro a destacar "dois movimentos" do romance, como erupção do eu que objetiva um mundo interior afetivo em forma de "propriedade privada"; e interiorização deste próprio mundo em forma de análise destruidora. Os dois movimentos opostos são considerados, contudo, como violências que produzem: “(...) São Bernardo-fazenda, que se incorpora ao seu próprio ser [de Paulo Honório], como atributo penosamente elaborado; da segunda [violência], resulta São Bernardo-livro-de-recordações, que assinala a desintegração da sua pujança. De ambos, nasce a derrota, o traçado da incapacidade afetiva." (CANDIDO, 1975: p. 23)'

Adotando a perspectiva de que o próprio personagem é quem escreve e de que de tal realização nasce a derrota, Antonio Candido coloca-nos diante de um paradoxo: se Paulo Honório escreveu o livro em que narra sua derrota, além de ter superado um obstáculo impensável, como uma história de tragédia poderia comportar a ideia de ser "livro de recordação"? Candido, com essa interpretação, vê no personagem um sadismo incrível, assim como João Pereira Pinto. Só explicável compreendendo a perspectiva que adotou:

(...) o verdadeiro drama da "consciência doentia" não se resume apenas nisso, começa com o fato da consciência por amor à consciência, da análise por amor à análise, - então sim, nasce o "homem subterrâneo". (...) A impotência sentimental do sarcasta, por uma fatalidade da compensação afetiva, produz uma violenta paixão de análise. $(. . .)^{78}$

Por trás dessa perspectiva, pela qual Augusto Meyer procura dar conta da obra machadiana ou de Machado de Assis, está a ideia de que se possa chegar ao autor pela ficção. Isto é, chegamos a uma espécie de confissão subjacente à obra relacionando-a com aspectos biográficos. Esse modelo não só é aquele que ganhou pulso no final do século XIX e sobrevive ainda nos dias atuais, mas também aquele que vai dar, muita vez, como a causa da interpretação da obra pelo crítico, uma espécie de "frustração do autor", em termos psicológicos, desencadeando violenta paixão de análise que se traduziria em arte. Por isso, para Candido, São

\footnotetext{
${ }^{78}$ MEYER, Augusto. “O Homem Subterrâneo” In: Textos Críticos / João Alexandre Barbosa (org.), São Paulo: Perspectiva, 19(...). (Cf. p. 197)
} 
Bernardo é "estudo patológico do sentimento de propriedade"; a deficiência da relação afetiva do protagonista o incita a escrever, "por uma fatalidade da compensação afetiva", como diz Meyer. Tal compreensão segue a mesma linha de Lúcia Miguel Pereira em análise da obra machadiana:

Sôbre a ebulição do fundo, a serenidade da forma se espraia, do mesmo modo que, no seu criador, a trepidação íntima se velava pela polidez quase fria. Quem o visse [Machado de Assis], composto e distante, não suspeitaria que aquêle homem manso e sêco vivesse "mastigando o seu desespêro, como uma espécie de gula mórbida". 79

Percebam-se aí as características fundamentais que a obra assumiria sob os aspectos de fundo (ebulição, literatura) e superfície (biografia) - consecutivamente ficção e confissão. A obra literária estaria aí carregada por elementos indiciais de fundo biográfico e psíquico, que elucidariam, pela obra literária, o "eu profundo do autor". Assim também o faz Candido, desde a análise de Caetés:

(...) poder-se-ia sugerir que os caetés simbolizam a presença de um eu primário, adormecido nas (...) [profundidades] do espírito pelo jogo socializado da vida de superfície - e que emerge periòdicamente, rompendo as normas. (...) Dêste modo, os índios que perpassam manifestam-se como subsolo emocional, que nêle [em João Valério] apenas aflora, mas que estaria chamado a desempenhar papel dominante na obra posterior [São Bernardo]. (CANDIDO, 1972: p. 16)

Isto é, tanto os índios em Caetés como o sentimento de propriedade de Paulo Honório subsistem nas entranhas de um eu profundo e adormecido como traços inconscientes, cuja relação entre ficção (superfície) e confissão (fundo ou subsolo emocional) permitiria a extração de elementos biográficos e psíquicos do autor que caracterizariam a própria obra num todo, explicando sua técnica de escrita, seu estilo e seus próprios mecanismos psicológicos. Os dados vão ser retirados, logicamente, de Infância. Mas, daí em diante, já não é mais de nossa alçada o problema a ser enfrentado. Está dado o caminho. E o que importa é compreender os pressupostos e categorias analíticas para, através do texto, ver se elas abrangem a complexidade da obra.

Estamos, aqui, diante daquela defesa que fez, contra a dos formalistas, de que "os elementos não-literários" não são anulados na obra literária. Com o que não concordamos: se assim fosse, o mundo simbólico da "coruja e seu pio" também deveria se manifestar de modo idêntico nas obras consideradas "biográficas"; o que vemos nelas, pelo contrário, é o inverso: Graciliano, ninguém duvida, jamais foi "supersticioso" ou religioso; sempre acreditou na análise material e racional da vida.

\footnotetext{
${ }^{79}$ PEREIRA, Lúcia Miguel. Prosa de Ficção (de 1870 a 1920) / Rio de Janeiro: José Olímpio, 1957. (Cf. p. 73)
} 
O pressuposto de Candido, portanto, é o de que "o sentimento de propriedade" seria essa manifestação inata e subsistente no $e u$ de Paulo Honório, que, manifestando-se na superfície das relações sociais, não se confundiria com a composição naturalista da personalidade exterior, “(...) atitudes e convicções que se apresentam, finalmente, como a própria personalidade. Em Paulo Honório, o sentimento de propriedade, mais que o simples instinto de posse, é uma disposição total de espírito". Que é, inclusive, o motivo de que

O próprio estilo, graças à secura e violência dos períodos curtos, em que a expressão densa e cortante é penosamente obtida, parece indicar essa passagem da vontade de construir à vontade de análise, resultando um livro direto e sem subterfúgios, honesto ao modo de um caderno de notas.

Aqui não há mais, como em Caetés, influências diretoras, jeito de exercício. Há um processo estilístico em maturidade, revelando o grande escritor na plenitude de recursos (...). (CANDIDO, 1972: p. 24)

Aquilo que Osman Lins identificou como uma espécie de descrição e caracterização microscópica do cenário e dos personagens, e que, segundo supomos nesse trabalho, é projeção narrativa de uma experiência sensorial própria de uma época, Candido caracteriza como violência produzida pelo sentimento de propriedade, particularizando o texto como uma produção isolada de qualquer outra manifestação literária (diz ele no início da análise do romance: “A expressão 'ocupa um lugar à parte na literatura' vive no bico das penas sem assunto. Não obstante, precisamos recorrer a ela a fim de entrar na análise de S. Bernardo”).

Assim, desse ponto de vista, unificam-se a pena de Paulo Honório e a de Graciliano, produzindo a autoria de São Bernardo. Daí um problema a resolver que a perspectiva de análise adotada por ele não pode. A saber, de quem seria o controle da realização escrita? Candido simplesmente aceita a verossimilhança do narrador. Diferententemente da aristotélica adotada por Osman Lins, ela é psicológica, dispensando a análise da construção ficcional em seus pormenores. A manifestação da escrita como resultado de um sentimento e do trauma produzido por ele assegura um meio de explicar o autor Graciliano do mesmo modo como enxerga Paulo Honório. E o método é análogo ao utilizado por Lúcia Miguel Pereira e Augusto Meyer na análise do autor de Memórias Póstumas de Brás Cubas.

A partir de um sentimento perturbador de domínio e de propriedade, do ciúme, da morte de Madalena - que não se submeteu ao domínio do fazendeiro -, explica-se o estilo de Paulo Honório, a secura, a violência das frases, a economia no cenário etc., daí ser derrota redentora. A intervenção de uma dor particular, na vida do autor, provocaria a possibilidade de 
aprimorar-se em técnica e estilo em termos de produção artística. Paulo Honório seria corpo e alma de Graciliano Ramos.

O importante é que Ficção e Confissão inaugura uma nova visada: "Paulo Honório literato", o que não se verifica nos decênios de 1930 e 1940 como possível: então, via-se em Graciliano o que era de Graciliano e jamais de Paulo Honório. Eis aí, na história da recepção crítica de São Bernardo, o divisor de águas que vai caracterizar o valor literário desse romance após os anos de 1950.

Ora, o que não podemos deixar de apreciar em Antonio Candido é a percepção de que as características naturalistas convencionalmente superficiais organizadas nas narrativas dessa tendência literária não estavam implicadas na construção da interioridade do personagem Paulo Honório: é algo interno que se objetiva nas relações de superfície, mas que não pode ser, a nosso ver, "sentimento de propriedade", porque essa categoria é datada e não pode ser simplesmente tomada como inata e subsistente no protagonista como fator psicologicamente naturalizado e humano como a fluidez do sentimento ${ }^{80}$. Daí os estudos que se seguem, depois do de Candido, tomarem essa característica e analisá-la em termos de reificação; isto é, como fator externo que implica as operações psíquicas do personagem: “(...) as características do modo de produção infiltram-se na consciência que o homem tem do mundo, condicionando o seu modo de ver e compondo-lhe, portanto, a personalidade” (LAFETÁ, 2004: p. 90).

A reificação de Paulo Honório, que já havia sido estudada por Luiz Costa Lima, é um fenômeno cujo efeito decorre das relações externas do indivíduo no mundo capitalista, não nasce pura e simplesmente de sua mentalidade, já que depende de um modo de produção histórico. Não nasce dele nem pode preexistir no sujeito, aguardando a atmosfera ideal para se manifestar, já que é necessariamente um processo que distorce as qualidades de produtos, coisas e pessoas pela medida do valor de troca e pela mais-valia, convenção de valor mercantil, regra de um jogo construído no mundo das relações de trocas capitalistas. Nesse sentido, a posição de Lafetá é contrária à de Antonio Candido, que havia constatado a não ocorrência desse processo em Paulo Honório com relação à profissão ou às relações econômicas externas ao indivíduo que engendrariam sua personalidade; contudo, o crítico vai manter a ideia fixa

\footnotetext{
${ }^{80}$ É a partir do século XX que passa a existir a “(...) ânsia de enriquecimento e prosperidade material. Isto, na monarquia, nunca se tivera como ideal legítimo e plenamente reconhecido." PRADO JR., Caio. História Econômica do Brasil / São Paulo: Brasiliense, 1972. (Cf. p. 208)
} 
de que "Paulo Honório nasce de cada ato, mas cada ato nasce por sua vez de Paulo Honório",

Contraditoriamente, quer dizer que a reificação subsiste no personagem, misturando psicologia e marxismo, negando as prerrogativas do último enquanto filosofia/sociologia que jamais se ocupou do capital como fenômeno psíquico anterior ao mundo que o produziu. $\mathrm{O}$ capital, diz Marx, “(...) é uma relação social de produção. É uma relação de produção histórica" ${ }^{82}$. Se cada ato "nasce" de Paulo Honório, então estamos diante da reificação enquanto fenômeno particular psicológico de uma consciência, o que se contrapõe à noção marxista de que as relações de produção capitalista constituem a consciência do homem, produzindo uma representação distorcida dos eventos e objetos nas relações sociais. Ou seja, origina-se no mundo das relações sociais, não na consciência ou mentalidade do indivíduo isolado.

Espera-se estar claro, até aqui, que o debate crítico se estabeleceu na base dos pressupostos teóricos, jamais sob a orientação de obra segundo o senso comum. Ou seja: a interpretação: tem como base o gosto particular - ou uma ideologia, um sistema de valor cultural que não se pode verificar na estrutura textual; os pressupostos são parte de um repertório crítico analítico com caráter objetivo, passível intersubjetivamente de verificação e descrição. Assim, a interpretação é totalmente subjetiva, ainda que, difundida culturalmente, pareça ter sido tirada das entranhas dos textos. Se isso fosse verdade, São Bernardo teria que ser, obrigatoriamente, lido dessa forma desde o primeiro momento de sua manifestação pública.

Assim, as categorias de fundo e superfície lançadas por Antonio Candido são mantidas aqui; mas não os pressupostos que as preenchem, consecutivamente, com sentimento de propriedade (fundo ou subsolo do eu) seguido de "objetivação do sentimento/confissão, escrita etc.” (superfície).

\footnotetext{
${ }^{81}$ Idem. p. 76

${ }^{82}$ MARX, Karl. A Origem do Capital: A Acumulação Primitiva / São Paulo: Global Editora, 1979. (Cf. p. 124, nota 4)
} 


\section{Entre achados e perdidos, ao menos fragmentos de capítulo}

- Maria das Dores, outra xícara de café.

Dois capítulos perdidos. Talvez não fosse mau aproveitar os do Gondim, depois de expurgados. 3

Começo declarando que me chamo Paulo Honório, peso oitenta e nove quilos e completei cinquenta anos pelo São Pedro. (pp. 11 e 12)

Ao final do segundo capítulo, Paulo Honório menciona "dois capítulos perdidos", juntamente com outros dois capítulos escritos por Gondim, que, simetricamente, foram planificados pela leitura da crítica como os capítulos 1 e 2 de São Bernardo:

"Dois capítulos perdidos". O caso é que não o foram. Sua figura dominadora e ativa está criada. Fomos já introduzidos em seu mundo - um mundo que, em última análise, se reduz à sua voz áspera, ao seu comando, à sua maneira de enfrentar os obstáculos e vencê-los. Um mundo que se curva à sua vontade. (LAFETÁ, 2004: p. 75)

O fato é que não temos acesso a esses capítulos. E, uma vez perdidos, é impossível recuperá-los ou saber o que havia neles. Os capítulos mencionados por Lafetá não são os escritos por Graciliano: essa figura dominadora, que vence tudo e subjuga a todos, curva todo o mundo à sua vontade, vimos, sofre três reveses, de imediato, no percurso de sua empreitada; recebe um belo "não pode porque não pode" na cara. Termina só no segundo capítulo, acossado pela superstição. Esse Paulo Honório avassalador só pode ser visto do ponto de partida do próprio Lafetá, já preenchido pelo caráter do Paulo Honório que vai surgir depois, a partir dos fatos desenrolados do capítulo 3 em diante.

Informados apenas da imperícia de Paulo Honório, de sua "incompetência literária", não é estranhável que a enunciação, no terceiro capítulo, tenha um caráter tão "antiliterário" como este: "Começo declarando que me chamo Paulo Honório, peso oitenta quilos...". Se aqueles dois capítulos "mentalmente compostos por ele no alpendre da fazenda" materializados depois na escrita pernóstica do Gondim - são os mesmos em termos de conteúdo, agora temos uma ideia do que havia neles neste início do terceiro capítulo, horrorosamente enunciado, em relação ao sofisticado "Antes de iniciar este livro". Sem os capítulos iniciais, esse terceiro faria rir inapelavelmente, pelo menos seu primeiro período.

Contudo, ele é duma coerência magnífica. Comparemos os requintes técnicos do "Antes de iniciar este livro" com o inepto "Começo declarando que me chamo Paulo Honório (...)”. O primeiro persuade pelo requinte técnico, na articulação das noções literárias 
implicadas nos termos "livro" e "imaginei" relacionados ao enunciatário. O segundo soa como se o romance necessitasse do performativo "declarar" - de ordem jurídica, como realização de um ato linguístico cuja necessidade de averiguação da condição de verdade não se faz obrigatória, tendo como validade o ato de declarar - para que o fato enunciado se legitime. ${ }^{83}$ Ora, está claro que há um desnível entre um e outro tanto no plano estético como técnica de persuasão, indicando as diferenças entre o $e u$ universal (que foi geralmente confundido com Graciliano) e o eu narrador explícito no romance.

O que temos diante de nós nesse terceiro capítulo é continuação dos esforços do protagonista, enunciados no final do capítulo 2. O tempo segue rigorosamente na mesma perspectiva de projeção futura: "Tenciono contar minha história" e "Começo declarando" são variações do futuro do indicativo, "contarei”; "começarei” ou "declararei”. Os capítulos perdidos, os primeiros no imaginário de Paulo Honório, os segundos na escrita de Gondim, surgem agora como utopia, no sentido que Barthes lhe atribui: contêm a mesma mensagem, mas só podem produzir efeito de sinceridade ou originalidade artística divorciadas do processo mental e pelo esforço de variação estilística do artista. A falta de originalidade, em termos literários, desse "Começo declarando" recupera o que Gondim tinha "acanalhado", expurgado de literatice e caracteriza a "palavra" de Paulo Honório como "verdade pura" e direta.

Esse processo caracteriza-se como enunciação-enunciada. Ou seja, o dizer "Começo declarando" - narração de Paulo Honório na continuação do enunciado, que teve início com o desenrolar do projeto de escrever o livro -, é enunciação-enunciada daquela instância que se pronuncia "Antes de iniciar este livro", significando que há um intervalo, entre o "antes de iniciar" e o "iniciar", em que ocorrem os fatos desenrolados. O processo iniciado com esta reduzida de infinitivo - leva-nos aos fatos desenrolados “antes". De lá, vínhamos acompanhando o processo imaginado pelo protagonista para compor o livro, que falha, afinal. A seguir, o vemos debruçado sobre a mesa, falando consigo mesmo (como se falasse a um leitor) ou com os coadjuvantes ao seu redor: "não pretendo bancar escritor; só vou escrever porque a obra será publicada com pseudônimo" etc. (um nome fictício que não menciona). Vem, no final do capítulo, uma pergunta de alguém que não sabemos: se dele

${ }^{83}$ Cf. em BARROS, 2001: p. 97; também em FIORIN, J. L. As Astúcias da Enunciação / São Paulo: Ática, 1996. 
mesmo ou de Maria das Dores, ou mesmo de Casimiro Lopes: "Então pra que escreve?" Se não pretende bancar o escritor!?

- Sei lá.

O pior é que já estraguei diversas folhas e não principiei.

- Maria das Dores, outra xícara de café.

Dois capítulos perdidos. Talvez não fosse mau aproveitar os do Gondim, depois de expurgados.

Começo declarando que me chamo Paulo Honório, peso oitenta e nove quilos e completei cinquenta anos pelo São Pedro.

Vemos o protagonista responder "Sei lá" a uma pergunta inscrita no espaço/tempo do narrador e, a partir do mesmo processo de espacialização e temporalidade (do discurso direto), pedir outra xícara de café, tornando o que era "narratário" em "interlocutor" direto (ele está, dentro do quadro construído no capítulo 1, agora, falando diretamente com quem está presente na cena). E, no terceiro capítulo, começar dizendo "Começo declarando": esse início ainda é "Antes de iniciar este livro", sem o qual ele não poderia "iniciar" algo. Ou seja, "Começo declarando" é elaboração mental da escrita, independentemente de ele escrever literalmente ou não. Acabamos de entrar na cabeça de Paulo Honório narrador, enunciado de quem enunciou "Antes de iniciar este livro". Assim se constrói o discurso metaliterário do romance. $\mathrm{O} e u$ da enunciação não se confunde com o $e u$ narrador: o primeiro é pressuposto, o segundo é explícito.

Poder-se-ia arguir que a instância enunciativa inicial é a mesma. Ora, que seja. Isso não garante que o que estamos lendo seja categoricamente o livro que vai ser escrito ainda na ficção. Graciliano tinha ciência de que a verossimilhança era conquistada ou produzida graças às repetições oportunas. O adiar o início do livro é que garante isso. Interpretar o livro de Graciliano como o de Paulo Honório é uma forma de aniquilar o texto, antecipar um fato que não se deu, apenas ficou prometido, graças ao intervalo temporal construído nos períodos "Antes de iniciar" e "iniciar" alguma coisa.

Outro ponto: os processos técnicos, estilísticos, do primeiro "eu" põem em dúvida que o segundo seja o mesmo: comparando os inícios, primeiros períodos de cada capítulo, o que vemos é um construído de forma rebuscada, cujos requintes técnicos pressupõem um romancista maduro; outro, quase exercício de redação de um aluno secundário. O que tudo indica, nessa mise-en-scène, é que se está diante, portanto, de um processo de elaboração mental, intelectual, de um indivíduo que não conhece os recursos estilísticos e estéticos do 
romance enquanto gênero, o que o faz um autodidata, explicitando o tempo inteiro o que adota ou não para escrever. O fato de se enunciar "este livro", e interpretá-lo como o mesmo "livro em mãos", não decorre de que necessariamente Paulo Honório já tenha escrito o livro; mas sim da consciência imaginativa do leitor e sua concepção de gênero e de arte literária. $\mathrm{O}$ intervalo temporal construído entre "Antes de iniciar" e o "iniciar" põe em cena o narrador dialogando com os interlocutores Casimiro Lopes e Maria das Dores e com sua própria papelada meio escrita. O interpelar "Calculem", do primeiro capítulo, concorda plenamente com os mesmos interlocutores (Casimiro Lopes e Maria das Dores) presentes na cena em que o protagonista está narrando:

Aqui sentado à mesa de jantar, fumando cachimbo e bebendo café, suspendo às vezes o trabalho moroso (...) Levanto-me, chego à janela que deita para a horta. Casimiro Lopes pergunta se me falta alguma coisa.

- Não

Casimiro Lopes acocora-se num canto. Volto a sentar-me, releio estes períodos chinfrins.

Ora vejam. Se eu possuísse metade da instrução de Madalena, encoivarava isto brincando. (cap. 2)

Essa forma de objetivar-se em plena atividade de raciocínio nada contém das hierarquias tradicionais do romance cujo narrador é autor-ficcional escritor. O trecho em que o personagem se desloca da mesa em que escreve à janela indica que ele não está escrevendo o que lemos; a descrição de Casimiro Lopes acocorando-se num canto da sala o faz observador e interlocutor do protagonista, que fala literalmente: "Ora vejam. Se eu possuísse metade da instrução de Madalena, encoivarava isto brincando". Em relação à realização escrita, de que tomamos ciência na leitura, poderíamos dizer que ela está encoivarada de forma brilhante, contrapondo-se à incapacidade de Paulo Honório realizá-la em forma escrita. Isto é, ele pensa, reage, projeta, enquanto na instância discursiva se realiza algo de que ele não tem a menor consciência. Isto é, tal instância do discurso o utiliza como máscara, manipulando-o.

O recurso de adiar o "início" dissimula as incoerências e abre perspectivas a outros planos possíveis, dando oportunidade de pensar ou construir o romance pelo ato de leitura autônomo do leitor, conforme suas expectativas de verossimilhança e de literalidade; articulando ele mesmo os elementos conforme a ordem e a coerência próprias de seu modo de apreciar a obra literária. O leitor é quem, conforme a estrutura narrativa, a partir da enunciação, transformando o texto em discurso, dá maior ou menor complexidade ao texto. 
A decisão interpretativa dos leitores de São Bernardo, arrolados até aqui, é legítima e autêntica por esse motivo; isto é, pelo caminho do processo de interpretação, não do significado que atribuem ao texto ou do que é literalmente o romance. E só a partir de outro olhar, que não o deles, é possível apreender a que elementos atribuíram maior ou menor importância na leitura; e, a partir daí, perceber o modelo e categorias empregados na atualização do significado da obra. Nessa perspectiva, é possível desvelar o percurso histórico. Veremos, por exemplo, que Paulo Honório, de "boçal e analfabeto", "grosseiro e ordinário", nos anos de 1930 e 1940, vai ganhar status, a partir da metade dos anos de 1950 em diante, de "escritor moderno", via psicanalítica; e, após, status de "modernista", que compreenderia o status literário da língua oral enquanto fator estético. Deixemos, porém, para mais adiante as avaliações finais de nosso percurso de pesquisa e análise do modo como os significados foram se construindo ao longo da história. 


\section{TERCEIRA PARTE}

\section{Um capítulo à parte}

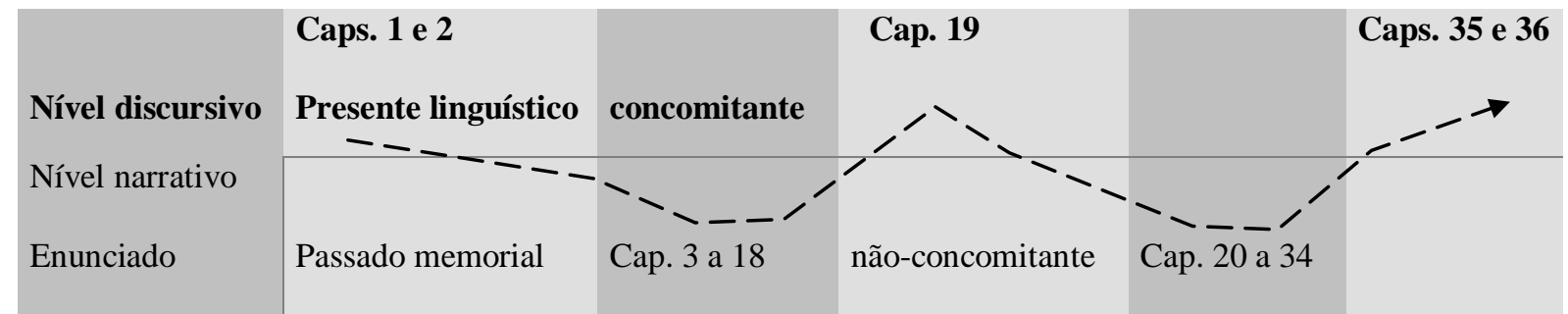

Até o último capítulo, vínhamos cuidando apenas da enunciação. Faremos, contudo, uma rápida incursão ao nível narrativo propriamente falado, o enunciado como passado memorial, cuja função especular, no romance, é pano de fundo: sabemos que ele trata do "fito na vida", "conquistar a fazenda", o que, no presente da enunciação, é um projeto ultrapassado. $\mathrm{O}$ fato novo para o narrador é transformar em livro o que surge de sua memória a partir do capítulo 3, o que doravante analisaremos. Contudo, sem irmos além do que já foi estudado incessantemente.

Observemos, no quadro acima, que há uma simetria entre os capítulos: da primeira metade da vida do protagonista, do capítulo 3 ao 18, temos exatamente 16 capítulos; e do 20 ao 35, outros 16, em que se conta sua falência. Os grandes picos de enunciação encontram-se nos capítulos 1, 2, 35 e 36. O 19 tem aspecto de fusão entre as duas metades do romance, ou seja, aspecto de encontro entre duas faces distintas do mesmo "eu", sobrepostas no ato enunciativo, já vistas a partir dos capítulos 1 e 2. Esse capítulo funciona como divisor de águas: divide a primeira metade da vida de Paulo Honório, em que se conta sua ascensão, durando cinco anos; enquanto a segunda, sua falência, cinco anos depois. O primeiro capítulo apresentou-nos o empreendedor, racional, cujas ações, com o caráter matizado na figura da "divisão do trabalho", o indexaram como uma "face dominadora", a que chamaremos de face 1. Já no capítulo 2, presenciamos o elemento mágico, a presença do fantástico, da religião e da superstição, nas reações de "espanto e estremecimento" ante a "falência do projeto de escrita" mediada por "o pio da coruja". A este caráter revelado da figura do protagonista damos o nome de face 2. 
O que vamos presenciar no enunciado, pela história de Paulo Honório, é, senão o surgimento, pelo menos a localização da face 1 do personagem no romance. $\mathrm{O}$ quadro abaixo apresenta de modo sintético o percurso dessa face e o da segunda face, apresentando-se a partir do capítulo 2, desvelada a partir do capítulo 20.

\begin{tabular}{|c|c|c|c|c|c|c|c|c|}
\hline & $\begin{array}{l}\text { Cap. 1 } \\
\text { Presente } \\
\text { Linguístico }\end{array}$ & $\begin{array}{l}\text { Cap. } 2 \\
\text { Presente } \\
\text { Lingtístico }\end{array}$ & $\begin{array}{l}\text { Cap. } 3 \text { all } \\
\text { Passado } \\
\text { Memorial }\end{array}$ & $\begin{array}{l}\text { Cap. } 12 \text { a } \\
16 \\
\text { Passado } \\
\text { Memonial }\end{array}$ & $\begin{array}{l}\text { Cap. } 17 a \\
18 \\
\text { Passado } \\
\text { Memonial }\end{array}$ & $\begin{array}{l}\text { Cap. } 19 \\
\text { Presente } \\
\text { Linguris tico }\end{array}$ & $\begin{array}{l}\text { Cap. } 20 a \\
34 \\
\text { Passado } \\
\text { Memonial }\end{array}$ & $\begin{array}{l}\text { Cap. } 35 \text { e } 36 \\
\text { Presente } \\
\text { Linguístico }\end{array}$ \\
\hline $\begin{array}{l}\text { Caráter } \\
\text { Ativo } \\
\text { Dominante }\end{array}$ & $\begin{array}{l}\text { Face } 1 \\
\text { Paulo H. } \\
\text { moderrizado: } \\
\text { sujeito à } \\
\text { cólera: } \\
\text { coletivizado }\end{array}$ & $\begin{array}{l}\text { Face } 2 \\
\text { Supersticãa, } \\
\text { Isolamento do } \\
\text { protagonista }\end{array}$ & $\begin{array}{l}\text { Face } 1 \\
\text { Ascensão } \\
\text { Conquista }\end{array}$ & $\begin{array}{l}\text { Face le } \\
\text { Face 2: } \\
\text { primeiro } \\
\text { ercortro } \\
\text { com } \\
\text { Madalena }\end{array}$ & $\begin{array}{l}\text { Face } 1 \\
\text { Casamento } \\
\text { com } \\
\text { Madalena }\end{array}$ & $\begin{array}{l}\text { Face } 2 \\
\text { Presertificacão } \\
\text { do pas sado }\end{array}$ & $\begin{array}{l}\text { Face le } 2 \\
\text { Corflito, } \\
\text { Declírio } \\
\text { da } \\
\text { Conquista } \\
\text { e Queda }\end{array}$ & $\begin{array}{l}\text { Face } 2 . \\
\text { Isolamerto } \\
\text { Completo: } \\
\text { Pera/Punição } \\
\\
\times\end{array}$ \\
\hline $\begin{array}{l}\text { Caráter } \\
\text { Passivo } \\
\text { Dominado }\end{array}$ & $\begin{array}{l}\text { Face 2 } \\
\text { Paulo H. } \\
\text { regiomalizado: } \\
\text { sujeito a } \\
\text { superstiçôes: } \\
\text { individualizado }\end{array}$ & $\begin{array}{l}\text { Face } 1 \\
\text { Falência da } \\
\text { cornqos ição do } \\
\text { livo } \\
\text { coletivamente }\end{array}$ & $\begin{array}{l}\text { Face } 2 \\
\text { Hula }\end{array}$ & & & & & $\begin{array}{l}\text { Face l } \\
\text { Falência total }\end{array}$ \\
\hline
\end{tabular}

Esse quadro, segundo as convenções de pesquisa, deveria ser apresentado no final das análises. Julgamos artificial tal disposição: é sabido que o que se apresenta já é, em partes, resultado da pesquisa e já estamos a mais de uma leitura do romance; o que significa, portanto, que se refletirá sobre a interpretação aqui realizada sob o aspecto da investigação de um efeito global. Além disso, os dois primeiros capítulos já evidenciavam, na enunciação, que o enunciador está acossado pelo prenúncio, o que significa o ponto de vista predominante da face 2 do discurso sobre a face 1, tornando propícia a averiguação dos motivos das falhas ou percalços que levaram à falência deste caráter empreendedor que por ela se apresentava justamente pautada pela modernização característica da figura "divisão do trabalho".

A seta branca, no quadro, indica as manifestações da face 1; a preta, os da 2. Os momentos em que elas rumam em direções diferentes significam a predominância de uma e a nulidade de outra. Quando se encontram em paralelas, há manifestações simultâneas das duas faces conflitantes em termos contraditórios ou ambivalentes. Evidentemente, esses momentos de desencontros e paralelismos cifram os relaxamentos e tensões do narrador em relação a si próprio na condição de memorialista e protagonista, cujo percurso em direção ao passado vai 
evidenciado os significados que tiveram em sua trajetória segundo aquele projeto de vida ou não. Reforcemos porém, que isso não é resolução, mas sim um problema a ser enfrentado ${ }^{84}$.

Dentro dos quadros apresentados acima, ocorre uma significativa curiosidade: considerando o capítulo 12 do romance como o ponto da estrutura linear sintagmática cuja característica repousa na ilusão produzida pelos ideais românticos, compreendemos qual a importância dele e das discussões do juiz de direito, Dr. Magalhães, com sua filha Marcela a respeito de quantos dias quantificariam "duas semanas". D. Marcela acredita passarem-se quinze dias; mas o juiz multiplica por 2 o número 7 , resultando 14 dias, o que contraria a ideia quinzenal de duas semanas. Tal aspecto do texto é indicial, isto é, fora do percurso sintagmático das funções e, portanto, metáfora. Deduzindo dos capítulos a ideia de multiplicação dos elementos, percebemos que o capítulo 1 nos dá como ambiente o círculo dos homens da cidade. O capítulo 12 é o momento em que se reúnem todos os caracteres ligados à cidade; multiplicando os capítulos, teríamos o 24 , e certamente um dos principais no tocante aos processos que vão desencadear a total desorganização mental e emocional do protagonista.

Em cada um destes capítulos, o tema que perpassa as questões, orbitando-as como algo casual e despretensioso, é o que pode produzir "os romances" como efeito na mentalidade de uma pessoa. Essa simetria entre os capítulos parece adequar-se aos momentos decisivos e de mudanças das situações que vamos acompanhando no desenrolar dos episódios: o capítulo 1 marca a não-reciprocidade entre o protagonista e os homens da cidade; o capítulo 2 revela seu lado não-prático. Assim sinalizado, do capítulo 3 ao 6 , romanescamente, temos a revelação do "herói”, da sua infância, segundo um padrão fragmentado de narrar, sua adolescência, a revelação ao fazendeiro Mendonça de que fora ali trabalhador no eito do antigo dono da fazenda. O capítulo 7, em que Paulo Honório contrata o guarda-livros seu Ribeiro, antecipa os problemas, que enfrentará em contato com a urbanidade, metaforizados na história de seu Ribeiro, de antigo major no passado a homem arruinado pela urbanização. Deste capítulo ao 12, onde conhece Madalena, teríamos uma nova unidade narrativa: no contato com o círculo dos homens influentes da cidade, procura

\footnotetext{
84 “(...) Como a significação de um texto pode ser experimentada se, conforme supõe a norma clássica de interpretação, já está aí à espera apenas da explicação referencial? O processo em que tal significação vem a se manifestar antecede toda tentativa de interpretação." (ISER, 1996: vol. 1 p. 47)
} 
adequar seus hábitos, manifestando certa incompreensão dos significados desse modo de se relacionar. Busca, inclusive, tentar instruir-se a respeito de "poesia".

Num processo acumulativo, superpondo episódios a episódios, estaríamos no capítulo 24, em que, depois de Paulo Honório ter casado com Madalena há dois anos, esse grupo conhecido de pessoas ligadas ao mundo burguês se encontra novamente para comemorar e, justamente aí, desenrola-se o conflito final do personagem com as ilusões produzidas pelo mundo burguês, respondendo à pergunta do capítulo 12 sobre "o que os livros poderiam fazer" (pergunta que faz a si mesmo o juiz de direito em função do sentimentalismo efetuado pelo romance em sentido de julgamento, do qual ele afirma não ter necessidade nem depender).

Passemos à análise desta hipótese de leitura e observemos o quanto ela nos permite extrair "trechos" literais de sua evidência. Desde já, adiantemos que o uso do quadro de análise semiótica doravante será bastante parcial: embora ela seja a perspectiva pela qual nos orientamos analiticamente, cremos ser desnecessário lançar mão na escrita de todo o seu aparato instrumental de análise, pois tornaria demasiadamente longo o estudo do passado memorial. 


\section{Memória fragmentada}

Possuo a certidão, que menciona padrinhos, mas não menciona pai nem mãe. Provavelmente eles tinham motivos para não desejarem ser conhecidos. (p. 12)

Estes primeiros períodos da vida do personagem, em que ele deduz os cinquenta anos de idade e apresenta seu aspecto físico, sua cor - "adoto-os porque estão no livro de assentamentos de batizados da freguesia" -, não podem ser entendidos senão por oposição a outros escritos de Graciliano. Deve-se, contudo, e é desejável, ao fazer relações comparativas, não perder de vista que a busca é de um significado e não de uma síntese completa de diferenças e semelhanças. A necessidade de conhecer outros romances de Graciliano, deriva, aqui, apenas da tentativa de obter melhor compreensão das possíveis referências de sentido do autor.

E é em Angústia que vamos colher algumas informações precisas a respeito do índice "certidão de nascimento": o ponto de vista do narrador Luís da Silva é o reverso da medalha do ponto de vista do narrador de São Bernardo. O que este alude como "motivos" de seus verdadeiros pais não o assumirem nominalmente em termos de paternidade, o outro, em Angústia, devido ao privilégio de ser filho de proprietário e de perspectiva diversa, não perde tempo em descrevê-lo como processo social de "abastardamento" e produção de "cabras" furiosos que povoaram o Nordeste. O ponto de vista o privilegia: Luís é filho de proprietário rural arruinado, por isso pode falar com detalhes sobre o que viu ou sabe, localizado que está num ambiente completamente diverso da situação em que se encontra Paulo Honório. O avô de Luís, o velho Trajano, foi proprietário escravista e, em sua relação com os moradores da sua propriedade, presenciam-se práticas não tão claras em São Bernardo: neste, o segredo está na base de toda compreensão e busca do narrador; naquele, é escancarado:

Os músculos de mestre Domingos eram do velho Trajano. Os músculos e o ventre de Quitéria também. Sinhá Germana concebia e paria no couro de boi, a que o atrito e a velhice tinham levado o cabelo. Quitéria engendrava filhos no chão, debaixo das catingueiras, atrás do curral, e despejava-os na esteira de Isidora, em partos difíceis ${ }^{85}$.

\footnotetext{
${ }^{85}$ RAMOS, Graciliano. Angústia / Rio de janeiro: O Globo; São Paulo: Folha de São Paulo, 2003. (Cf. p. 136)
} 
Este é um detalhe de Angústia que complementa certa lacuna em São Bernardo em função das características de seus narradores. A figura de Isidora, em Angústia, é análoga à da velha Margarida, a negra que cuidou de Paulo Honório na meninice. O velho Trajano ocupa a mesma posição do velho Salustiano Padilha, pai de Luís Padilha, filho e proprietário anterior de São Bernardo; há também, nessa posição, em São Bernardo, o proprietário da fazenda Bom-Sucesso, o Mendonça. O que nos conta Luís da Silva não pode ser contado pelo protagonista de São Bernardo: os detalhes "volumosos" em Angústia esclarecem-nos a origem de indivíduos parecidos com Honório, o que lhe confere as características que surgem mais à frente. Em Angústia, conta-nos Luís que Quitéria (que tem como congênere Maria das Dores e a Rosa do Marciano em São Bernardo) e outras mulheres, juntamente com o velho proprietário rural, povoaram o sertão de "cabras brabos" que andavam pelo Nordeste provavelmente como cangaceiros e jagunços:

\footnotetext{
São do meu tempo os dois últimos partos de Quitéira. Sinhá Terta, parteira da fazenda, batia a tramela do quarto pegado à cozinha. Trajano rondava a porta, preocupado com a cria (...) Depois, uma coisa derramava e sinhá Terta dizia:

- Louvado seja Nosso Senhor Jesus Cristo.

Meu avô serenava ${ }^{86}$.
}

Se para Luís da Silva essa lembrança tem como função localizar determinados homens em quem procura "a bravura e a coragem" para assassinar, depois, Julião Tavares, deduz-se que, em São Bernardo, o sentido da certidão de nascimento de Paulo Honório deve ter o mesmo lastro; mesmo não podendo ele ser confirmado categoricamente com palavras, mas indiciado no prazer de Paulo Honório em humilhar o Padilha, como seu empregado, e nos trechos em que parece querer revelar sua identidade nativa em forma de reversão de um processo começado ali em São Bernardo. Por contraste, é o que pode e leva o protagonista a dizer que "Se tentasse contar-lhes minha meninice, precisava mentir. Julgo que rolei por aí à toa. Lembro-me de um cego que me puxava as orelhas e da velha Margarida, que vendia doces".

O que vai surgindo da narrativa de Paulo Honório como memória é completamente diferente do "sumário narrativo" que vemos economicamente construído em Angústia: o estilo da narrativa deste é semelhante ao realista de apresentação e descrição (ainda que embutida na história principal de Luís da Silva). Se Paulo Honório tivesse que contar sua meninice, talvez tivesse que "inventar" seu nascimento, com o velho Padilha ou o Mendonça

${ }^{86}$ Idem, p. 136 e 137. 
rondando a porta de uma parteira; aliviados depois que entregassem a criança à "esteira da velha Margarida". Isto é, seria obrigado a mentir. Não haveria nem meios de ele saber disso nem elementos que o orientassem na narração. Mas isso não o impede de suspeitar. A “certidão de nascimento" de Paulo Honório é índice, portanto, de um significado virtual, fora da isotopia dos elementos de ação que caracterizam o personagem em nível de um fazer:

(...) a sanção dos índices é "mais alta", por vezes mesmo virtual, fora do sintagma explícito (o caráter de um personagem pode não ser jamais nomeado, mas entretanto ininterruptamente indexado), é uma sanção paradigmática; ao contrário, a sanção das Funções é sempre "mais longe", é uma sanção sintagmática. $^{87}$

Daí a certidão remeter a relações históricas da constituição da família ruralista, cuja historiografia recente vem revelando-nos dados curiosos de sociabilidade. Apesar de que Paulo Honório não possa saber quem eram seus pais, ele sabe e guarda em segredo o nome dos padrinhos, o que caracteriza certa organização hierárquica de poder e relação verticalizada de origem escravocrata:

(...) os senhores não se tornavam padrinhos dos próprios escravos e só raramente os parentes do senhor exerciam esse papel, (...) Havia uma espécie de categoria de compadrio que reproduzia a hierarquia de status e cor da sociedade, e os brancos, quase sempre, tinham padrinhos brancos; (...) quando cidadãos livres serviam de padrinhos de escravos, geralmente tinham status inferior ao do senhor desses escravos. (...) Os filhos legítimos tinham mais probabilidade de ganhar padrinhos de status mais alto e uma cerimônia "normal", (...) ao passo que os filhos ilegítimos poderiam não ter madrinha registrada ${ }^{88}$.

Essa característica de organização surgida nas práticas escravocratas explica, inclusive, a menção feita à imprecisão da data de batismo do protagonista, localizando-a no "São Pedro", período das festas religiosas em que oportunamente cerimônias simples de compadrio eram recorrentes: “(...) como a do dia de São João, quando, ao dar as mãos e pular a fogueira juntos, os indivíduos podiam tornar-se "compadres de fogueira"” (SCHWARTZ, 2001: p. 266). Em suma, quando Paulo Honório se refere a estes "fatos", surgidos aparentemente ao sabor da memória, também parece indicar suas relações com os fatos advindos deles. A velha negra, agregada do velho Salustiano Padilha, é quem vai emprestarlhe o significado de "mãe" e embutir-lhe a mentalidade que apresenta; mais à frente o

\footnotetext{
${ }^{87}$ BARTHES, Roland - "Introdução à Análise Estrutural da Narrativa". In: Análise Estrutural da Narrativa Seleção de Ensaios da Revista Communications: Intr. Milton José Pinto; Rio de Janeiro: Ed. Vozes Ltda., 1973. (Cf. p. 31)

${ }^{88}$ SCHWARTZ, Stuart B. Escravos, Roceiros e Rebeldes / Bauru, S.P: EDUSC, 2001. (Cf. p. 272)
} 
veremos chamá-la de "mãe Margarida". Inclusive com um afeto e uma consideração pouco comuns dedicados a qualquer outro indivíduo durante todo o romance, o que indica uma profunda ligação entre os dois: a volta da negra a São Bernardo é comemorada inclusive com a compra de equipamentos para o jornal dirigido pelo Gondim, tendo este realizado a promessa de encontrá-la. E, nas duas vezes em que a vemos falar, compreendemos essa ligação.

A primeira conversa entre ela e o proprietário de São Bernardo, no capítulo 10, revela-nos as mesmas características do protagonista: ao chegar à fazenda, ele acocora-se ao lado dela, quase cega, e diz: "Uma fraqueza apertou-me o coração, aproximei-me, sentei-me na esteira, junto dela". Diz a ela que peça o que quiser, tudo que for necessário, ao que a velha responde:

\footnotetext{
- Para que tanto luxo? Guarde seus troços, que podem servir. Em cama não me deito. E quem dá o que tem vem a pedir.

- Não faz mal, mãe Margarida. Esteja sossegada, durma sossegada. Faltando lenha para o fogo, avise. Não deixe o fogo apagar, que as noites estão frias.
}

Ora, sendo ela que o encaminhou na vida, não deve soar de modo estranho aos ouvidos de Honório o dito "Guarde seus troços, que podem servir. Quem dá o que tem vem a pedir". Certamente é um dos elementos que dão forma ao seu modo de pensar como um dos traços mais característicos da face l. É o que se vai repetir no segundo encontro com a velha, já casado com Madalena. Tendo Honório lhe perguntado se faltava alguma coisa no rancho, responde que "Falta nada! Tem tudo, a sinhá manda tudo. Um despotismo de luxo: lençóis, sapatos, tanta roupa! Para que isso?" (Cf. cap. 23). Ao passo que há preocupação do personagem com a falta de algo à velha, percebe-se que o modo de assistir de Madalena parece não satisfazer adequadamente. A cólera de Paulo Honório não estará mais localizada na "assistência realizada", com a qual ele mesmo manifesta preocupação de que se realize; a irritação dele vem dos fundamentos da assistência, que interfere no modo como aquele mundo está organizado e o modifica: a velha negra o interpela, inclusive, pedindo-lhe explicação: "Pra que isso?".

Aliás, uma atitude "despótica", contra o comportamento de um proprietário, porque desajusta a condição "normal" daquele que habita terra alheia, elevando-o à mesma condição, por força, ou provocando em seu comportamento atitudes inconvenientes. A forma como 
Madalena trata o assunto, segundo a velha, não estava de acordo com sua expectativa e não a beneficiava porque contrariava as regras de tratamento não só dela, mas de qualquer outro morador da fazenda, pondo em risco o proprietário no sentido da expressão "quem dá o que tem vem a pedir".

O que está na base desse capítulo 3 não é apresentado por um narrador realista típico; só vamos compreender a questão da infância através do que diz a velha Margarida no encontro com o afilhado, do capítulo 10 em diante, e de modo narrativamente fragmentado: "Como estava com a vista curta, falou sem levantar a cabeça, repetindo os conselhos que me dava quando eu era menino". Fragmentada pela memória, a narrativa apresenta diferentemente das narrativas lineares, temporal e espacialmente bem determinadas no encadeamento lógico de certas convenções literárias - explicações fornecidas pela caracterização de eventos isolados, descontínuos no espaço-tempo e juntados por relação metonímica - que, do ponto de vista da convenção realista de apresentação, exigiriam o "sumário narrativo" e o controle total do narrador sobre os episódios agrupados numa unidade de sentido. Não há, em São Bernardo, essa experiência que se revela na recepção por alijar o que parecem ser "fatos alinhavados ao sabor da memória" ou "detalhes que surgem".

É preciso remontar a história segundo sua estrutura e identificar a convenção literária implicada; quando o fazemos, não temos mais nenhuma dúvida em afirmar que ela está ligada ao modernismo. Como em Grande Sertão: Veredas, em que micronarrativas ou episódios estranhos explicam o que Riobaldo deseja comunicar, em São Bernardo também estão na base do processo narrativo.

Quanto à caracterização tipológica da velha Margarida em termos literários e sociológicos, pode-se falar tanto em "compadrio" quanto em "agregado". A fala de Margarida parece ser discurso do proprietário incorporado particularmente e de um juízo compartilhado coletivamente que estabelecem entre eles um pacto de fidelidade e sujeição como reprodução de relação de poder preestabelecida na hierarquia: ela é negra; ele é branco; ela, agora, é agregada, ele é o patrão; ela não é mãe dele, portanto não tem o direito de gozar dos privilégios do patrão. É uma fala anterior ao proprietário Paulo Honório que vai se tornar a de Paulo Honório; uma fala que lhe chega aos ouvidos, na sua meninice ou adolescência, através da velha negra, com caráter proverbial e como reprovação da generosidade. 
O dito "quem dá o que tem vem a pedir" junta-se à afirmação de Paulo Honório de que ela "falou sem levantar a cabeça, repetindo os conselhos que me dava quando eu era menino"; veja também a própria fala do proprietário, "Um despotismo de luxo (...) Para que isso?" São palavras que vai usar Honório no episódio da compra de material escolar a pedido de Madalena ou quando a esposa faz justiça por si mesma, levando-o a repetir essas palavras para si mesmo. É uma concepção, portanto, que o antecede e que the chega pela "mãe Margarida", bem como pelo mundo organizado como tal; ela, como uma "fada madrinha", é a quem ele "deve" prestar homenagem e gratidão.

Cada uma dessas linguagens revela uma visão de mundo, um universo ideológico próprio. A linguagem restrita e concreta de Paulo Honório é a expressão de um conhecimento de mundo marcado pela experiência, pelo contato direto, vivencial, com um universo particular (a fazenda). (MARINHO, 2000: p. 55)

Esse é um dos aspectos mais importantes da orientação de vida do protagonista. Tal detalhe impede a avaliação do romance como um estudo do sentimento de propriedade, apenas: por ser anterior à posse da fazenda, não surge da aquisição e das relações nela estabelecidas nem subsiste em Paulo Honório, manifestando-se de forma inata. A velha Margarida, como nas convenções romanescas, vai prepará-lo em termos de tradição, a partir do que deve ser conhecido e incorporado como pacto com o poder e manutenção do mesmo, não pelo controle do capital ou do meio de produção, mas por um tipo de conduta que desempenha a função de naturalizar sua liderança (muito diferentemente do modo capitalista, em que o poder se realiza pelo contrato impessoal que pode ser rompido, que é o que acontece no primeiro capítulo com a não adesão dos colaboradores ao projeto de escrever o livro). Quando a velha se autorreprime, como repreensão a Paulo Honório, manifesta o mesmo juízo, por exemplo, de Fabiano em Vidas Secas, que, percebendo ir além do seu papel ou lugar estabelecido na vida, diz a si mesmo que "é um bicho": a voz de outro, nele incorporada, reprime seus rompantes de valentia ${ }^{89}$.

Essas falas interiores em Fabiano, como as exprimidas em forma de provérbio pela velha Margarida, revelam o universo do dominador ou mandatário e dão um conhecimento direto a Paulo Honório do comportamento de um proprietário e do modo de

\footnotetext{
89 "A ideia de um discurso que é o tempo todo atravessado pelo alheio, que traz no seu interior o outro, é um dos pontos mais importantes do pensamento de Bakhtin e vai desembocar na noção de dialogismo, por ele formulada (...)" (MARINHO, 2000: p. 36)
} 
permanência/manutenção de seu domínio ${ }^{90}$. Se assim não fosse, julgar-se-ia a velha Margarida perfeitamente "reacionária", quando, pelo contrário, o que ela pensa e reproduz foi-lhe incutido na forma de raciocinar o mundo, de um dado ponto de vista que é desconhecido e rejeitado pela estrutura burguesa de relações impessoais mediadas pelo dinheiro.

O próprio Paulo Honório fica confuso e inseguro a respeito da localização dessa voz em seu pensamento; no episódio da doação de sapatos, lençóis e vestidos de Madalena, assim diz ele: "O que me pareceu foi que Madalena estava gastando à toa. / - À toa, percebem? / Repeti para convencer-me: - À toa. Desperdício.” (cap. 23). Essa forma de dizer a si mesmo, e em voz alta para que os outros ouçam, é também indício de sua falta de contato e aprendizagem direta, em sua experiência como herdeiro, do modo de ser de um proprietário rural naquelas condições: seu conhecimento de tal comportamento é de dicto, não de re, isto é, não da coisa em si, mas pelo dito. Repetir o juízo para si mesmo é sinal de pouca segurança quanto à eficácia das decisões fundadas nele, e também sinal das incertezas desencadeadas pelas decisões tomadas. Mas também é a encenação da face 1 como superfície, não como profundidade.

Ao compararmos os pontos de vista do protagonista de São Bernardo com o do proprietário rural por estirpe, Luís da Silva, percebemos o acanhamento do outro em discorrer livremente sobre o assunto de sua origem. Enquanto Luís se lamenta por ter perdido as características sertanejas e desejar tê-las a fim de vingar-se de Julião Tavares, Paulo Honório foi apoderado por elas de tal modo que nem mesmo é capaz de neutralizá-las pela análise consciente das suas causas, enquanto narra. Daí Paulo Honório dizer nos primeiros parágrafos de sua história: "Sou, pois, o iniciador de uma família, o que, se por um lado me causa alguma decepção, por outro me livra da maçada de suportar parentes pobres (...)".

Ora, a decepção não pode advir senão de sua condição de ter uma "origem incerta", provavelmente bastarda, já que tais parentes teriam a mesma origem e toda uma rede de

\footnotetext{
${ }^{90}$ Parece que Graciliano quebrou os versos ou o ritmo das frases da fala da velha negra para que não soasse fora do propósito realista (que ele, por força do momento histórico, não rompe completamente): retirando o trecho que quebra o ritmo poético e insere o tom de prosa, teríamos uma quadrinha assim: "Guarde seus troços / Que podem servir / Quem dá o que tem / Vem a pedir". Numa crônica escrita em 16 de maio de 1994, "Conversa de Bastidores", vai elogiar efusivamente este traço em Guimarães Rosa, apontando-o em "O Burrinho Pedrês". E mesmo em São Bernardo, no capítulo 25, quando Casimiro Lopes entoa cantigas ao seu filho, vai-se apresentar o mesmo processo de dialogismo: "Eu nasci de sete meses / Fui criado sem mamar / Bebi leite de cem vacas / Na porteira do curral".
} 
relações de "proprietário, agregados e apadrinhados" que o rebaixariam. Portanto, a certidão de nascimento do personagem funciona como índice de suas suspeitas de origem: ou ele é filho do velho Salustiano ou de algum vizinho de "casta superior": não é um "molambo" (característica dos pobres, como Marciano). Daí, nem o conceito de "proprietário", tampouco a ideia de "prosperidade material" darem conta de sua mentalidade complexa e, por vezes, a reduzirem e simplificarem demais.

Na enunciação, já estamos advertidos de que, para o narrador, "isso ia seguindo sem nenhuma ordem". Do ponto de vista daquele enunciador que põe em foco a narração do protagonista, o significado é que na desordem da memória não cabe nenhum estilo, nenhuma marca de ordem literária, porque produziria uma "artificialidade" e uma estrutura de pensamento e organização burguesa inadequadas ao caráter particular do narrador. Daí certa dificuldade de análise desses capítulos iniciais a partir de noções clássicas como "cena/cenário" ou "sumário narrativo", "narrador onisciente" etc. O que veremos tem certo aspecto romanesco e, juntamente com outras unidades, apresentará aparências épicas até certo ponto biográficas.

Um romance ou autor realista tradicionalmente poria essa desordem nos moldes do cânone, linearmente; com cenários enquadrados perfeitamente numa forma de descrição realista- naturalista, unificando a dispersão de elementos. Tratando-se de um romance moderno, o processo é composto de fragmentos de memória encadeados metonímica e metaforicamente; e, ainda que guarde alguns resquícios de "realismo", é preciso avaliar com cautela os processos do romance que os deixam transparecer. Em São Bernardo, a ordenação ou linearidade não se realiza senão pelo leitor, segundo sua concepção de arte. Daí outras hipóteses e o motivo daquela adequação aplicada à narrativa, como a de Álvaro Lins, de que o romance só teria início com o casamento e os desacordos do casal Paulo e Madalena. É claro que a leitura dele não só é bastante pertinente como uma coordenada do pensar literariamente um modelo-padrão literário. O único problema é que tal adequação descarta desde o capítulo 3 até o 17, por não haver aí nem o mesmo padrão tampouco o mesmo efeito estético.

É também o mesmo tipo de adequação que Candido opera, quando diz que São Bernardo é um estudo do sentimento doentio de propriedade: estes primeiros capítulos não o interessam (o que inclusive o levou a considerar, com Álvaro Lins, não haver nenhum sentido no capítulo 7: o próprio Candido diz isso no prefácio de $A$ Dimensão da Noite, 
reconhecendo os esforços de Lafetá em incluí-lo nas análises. Os olhos do crítico - superada a ideia da inverossimilhança do narrador autor-fictício - captam a propriedade São Bernardo como uma totalidade psíquica. Isto é, não há nada fora de São Bernardo livro e São Bernardo fazenda que não esteja dentro do protagonista e narrador como configuração interna; nada é anterior ou posterior a ele, tampouco externo; o que o leva à conclusão de que “o seu drama é cruel porque há fissuras de sensibilidade, (...) bons sentimentos não envolvidos nela [a fazenda]" (CANDIDO, 1972: p. 22). O estudo de Candido desenvolve com mais precisão as ideias de Álvaro Lins, sob o componente estético sentimento, característico do romance romântico. De fato, isso ocorre apenas a partir do casamento de Paulo Honório e Madalena. Mas a redução tem o prejuízo de descartar os processos históricos e sociais articulados na construção da ficção.

O afeto revelado por Paulo Honório em relação à velha Margarida é reprimido pela ideia de que a generosidade é caminho da miséria: "quem dá o que tem vem a pedir". Se isso tem origem, pelo menos até o ponto em que pode ser averiguado na estrutura do romance, não pode ser no interior do protagonista ou desencadeado pela aquisição da fazenda: não há aí nenhum apontamento de processos psíquicos dinâmicos no desenlace da aquisição, dividindo suas atitudes em $u m$ antes e $u m$ depois dela. $\mathrm{O}$ caminho da aquisição é, sem dúvida, esse princípio "não generoso" apresentado nas relações sociais do mundo capitalista, combinado à reação violenta, anteriormente dada, juntamente com a vontade de vingança típica da codificação da honra na ordem colonial-patriarcal:

Até aos dezoito anos gastei muita enxada ganhando cinto tostões por doze horas de serviço. Aí pratiquei o meu primeiro ato digno de referência. Numa sentinela, que acabou em furdunço, abrequei a Germana, cabritinha sarará danadamente assanhada, e arrochei-lhe um beliscão retorcido na popa da bunda. Ela ficou-se mijando de gosto. Depois botou os quartos de banda e enxeriu-se com o João Fagundes, um que mudou o nome para furtar cavalos. O resultado foi eu arrumar uns cocorotes na Germana e esfaquear João Fagundes. (Cap. 3)

É o primeiro ato digno de referência porque o separou de indivíduos como Marciano (congênere de Fabiano), sem reação ante a desonra, pela "vingança" realizada como êxito e referida como "ato digno" de homem que sofre algum tipo de afronta moral. E esse primeiro ato, para que se comprove, precisa ser experimentado no ambiente do alto sertão, onde vivem "os cabras" mais perigosos e para que o "heroi" seja provado. Isto porque, apesar de o ato ser digno de referência, os elementos que o configuram parecem desvalorizá-lo, ironicamente; não só por supor a "traição" de Germana, a prisão de três anos, nove meses e quinze dias, a 
sova de cipó e as diarreias provocadas pelo chá de cabacinha, mas pelo fato de não lhe ter rendido nenhum respeito. Ao sair da prisão, diz, a Germana estava na vida, de portas abertas como prostituta e com doença venérea. A violência pela violência não lhe trouxe nada além da prisão, da surra de cipó e da certeza de que lutou por nada, restando apenas o ato porque, ao experimentá-lo, podia repeti-lo: "meu primeiro ato digno de referência". O valor desse ato contraria expectativas. Mas precisa ser compreendido como pode vir a ser valor.

É nesse intuito que deixa a Zona da Mata e vai para o alto sertão, onde as transações se realizavam de arma em punho. A reação violenta ante as adversidades será a norma de ascensão, prosperidade e respeito. Poder-se-ia pensar que isso é uma "interpretação"; o que decorre de concepções estruturais segundo o romance típico. O caso é que é um dado do próprio texto, só compreendido quando anulamos a ideia de um narrador realista onisciente; e esperamos, conforme o modo de ver Paulo Honório, metonimicamente a explicação. Que vem no capítulo 26, após Madalena chamá-lo de "assassino" e quando ele passa a pensar o que poderia estar por trás dos desentendimentos:

Assassino! Como achara ela uma ofensa tão inesperada? Acaso? Ou tinha lido o jornal do Brito? Mais provável era o Padilha haver referido alguns mexericos que por aí circulam. Sim senhor! Estava o Padilha mudando em indivíduo capaz de fazer mal. Que graça! O Padilha! Recordei-me do caso do Jaqueira, mas a recordação desapareceu (...) (Cf. cap. 26)

Evidentemente o valor do ato, assassino, remete a um ponto de vista sobre a ação. Mas a associação entre a recordação do caso Jaqueira e o fato de que Padilha estivesse envolvido em uma transformação capaz de prejudicá-lo vingativamente são elementos que complementam o sentido e valor do "primeiro ato digno de referência" e da "certidão de nascimento". Observe-se como a lembrança do caso Jaqueira não só se assemelha com esse primeiro ato como, supõe Honório, poderá estar acontecendo com o Padilha, após sofrer dano semelhante no sentido da humilhação imposta a ele por Paulo Honório, ou ainda estar na base dos segredos de sua natalidade:

O Jaqueira... Ah! sim! tinha sido anos atrás. (...)

O Padilha! Cabra ruim é que desgraça um homem. Quem havia de supor que o Jaqueira...

Outra vez o Jaqueira. Aqui vai, resumido, o caso do Jaqueira. Jaqueira era um sujeito empambado, e os moleques, as quengas de pote e esteira, batiam nele. Jaqueira recebia as pancadas e resmungava:

- Um dia eu mato um peste.

Toda gente dormia com a mulher do Jaqueira. Era só empurrar a porta. Se a mulher não abria logo, Jaqueira ia abrir, bocejando e ameaçando:

- Um dia eu mato um peste. 
Matou. Escondeu-se por detrás de um pau e descarregou a lazarina bem no coração de um freguês. No júri, cortaram a cabeça por seis votos (patifaria). Saiu da cadeia e tornou-se um cidadão respeitado. Nunca mais ninguém buliu com o Jaqueira. ${ }^{91}$

Essa pequena narrativa do caso Jaqueira tem todas as características do caso “Germana e João Fagundes”, que já era um “cabra”, indicando, portanto, que Paulo Honório estava na posição do Jaqueira. Com a diferença de que Paulo Honório, ao sair da cadeia, ainda não terá adquirido o respeito e conquista da dignidade: esse "algo mais", que vai restaurar a honra e impor o seu valor, é a aquisição da propriedade em que nasceu e foi criado. E, ainda, que Padilha, quando na posição de Paulo Honório como funcionário da fazenda, poderia estar se transformando num "cabra ruim" capaz de vingar-se. Assim, a respeitabilidade, a ofensa e a reconquista da moral são percebidas. Há ainda a hipótese de que Paulo Honório tenha tido essa origem: o caso Jaqueira é o ponto de vista do homem desonrado que, por exemplo, Luís da Silva não refere quando narra em Angústia a realização dos partos cuja causa era seu avô.

Há claras alusões em São Bernardo de que a Rosa, mulher de Marciano, esteja nessa situação: após o protagonista ter expulsado Padilha e Marciano da fazenda, é a Rosa quem vai falar com ele, exatamente no capítulo 11, onde diz ter amanhecido pensando em casamento: “(...) a Rosa, com cinco filhos (três agarrados às saias, um nos braços, outro no bucho,) atracou-me no pomar. E eu, que não tenho grande autoridade junto dela, sosseguei-a [voltando atrás na decisão de expulsá-los da fazenda]” (pp. 60 e 61).

Além desses "detalhes todos", vai acontecer em Bom-Sucesso que uma menina de lá será "desgraçada" e Mendonça acusa um moleque de São Bernardo de ser o responsável: "Discórdia séria só esta: um moleque do S. Bernardo fizera mal à filha do mestre de açúcar de Mendonça, e Mendonça, em consequência, metera o alicate no arame; mas eu havia consertado a cerca e arrumado casamento do moleque com a cabrochinha” (p. 32).

Observe-se que, para se tornar proprietário da fazenda, mais que emprestar dinheiro ao Padilha, foi necessário enfrentar essa mesma violência e modo de vida, no passado, reproduzindo-os no presente. O que começa a experimentar em si mesmo como "reação" à sua condição naquela estrutura agreste, de enxadeiro, para conquistar seu lugar legítimo como "chefe", não se confunde com as ações de um empresário/empreendedor. É esse o

\footnotetext{
${ }^{91}$ Cf. em Sagarana conto semelhante ao caso do Jaqueira, em "Duelo", em que Turíbio Todo surpreende um freguês entrando em sua casa, esconde-se atrás de um pau e dá um tiro no amante da mulher. É também um conto em que o personagem que sofre a desonra transforma-se em uma espécie de "cabra ruim".
} 
molde de construção da face 1, cuja máscara empreendedora de modernidade não chega a esconder seu verdadeiro lado agreste e arcaico. E quando diz "Afinal, cansado daquela vida de cigano, voltei para a mata." E que "Casimiro Lopes, que não bebia água em ribeira do Navio, acompanhou-me", Paulo Honório não engana: a fixação na fazenda não deixa dúvidas de que seu plano não é só adquiri-la; mas infligir, sobre quem ele suspeita ter-lhe tomado a honra, as mesmas vergonhas que talvez sinta e ainda lhe desgoste sentir. O desejo de revelar o que ele diz - para contar, "teria de mentir" - escapa-lhe aqui ou acolá. E o leitor atento deve perseguir as pistas deixadas pelo caminho da narração, indignando-se depois: esse efeito anula a compreensão dos segredos. 


\title{
3. A volta do filho às avessas
}

\author{
O capital é uma relação social \\ de produção. É uma relação de produção histórica. ${ }^{92}$
}

São Bernardo, em que trabalhou até aos dezoito anos e onde esfaqueou João Fagundes, tem enorme valor simbólico para o protagonista: “(...) gastei muita enxada ganhando cinco tostões por doze horas de serviço." No capítulo 4, ao resolver voltar "à mata", diz o seguinte:

Resolvi estabelecer-me aqui na minha terra, município de Viçosa, Alagoas, e logo planeei adquirir a propriedade S. Bernardo, onde trabalhei no eito, com salário de cinco tostões.

Meu antigo patrão, Salustiano Padilha, que tinha levado uma vida de economias indecentes para fazer o filho doutor, acabara morrendo do estômago e de fome sem ver na família o título que ambicionava. (pp 15 e 16)

Salustiano Padilha parece-nos, em nível paradigmático, exercer a mesma função que Trajano em Angústia, embora quase não haja narrativa sobre isso. Mas está claro que Paulo nasceu e foi criado em sua fazenda e que não tinha pai nem mãe; e Padilha, filho de Salustiano, não parece tê-lo conhecido: o filho de Salustiano (aliás, também chamado Luís) situa-se na mesma posição de Luís da Silva em Angústia. Sendo uma das características de Honório a vingança - no capítulo 3 ficamos sabendo disso pela declaração de que ele "esperneou nas mãos do Pereira" em função de juros cobrados pelo empréstimo do capital inicial que o alavancara, tendo-se vingado do agiota depois -, não seria estranhável que seu retorno a Viçosa tivesse essa finalidade: primeiro, pelo modo como deixa o lugar e vai para o altosertão; segundo, pela forma, ao voltar a Viçosa, com que se refere ao antigo patrão e ao filho, espécie de ressentimento contido pelo modo de narrar.

Conta-nos que se vingou do Pereira, tirando-lhe as propriedades pelo mesmo mecanismo usado pelo agiota; tal mecanismo é o mesmo que vai usar para tirar de Padilha as terras de São Bernardo. Por isso, não é só um capitalista, aplicando as regras do jogo da livre concorrência, pois as usa a fim de saciar suas prováveis revoltas e firmar-se legitimamente como digno de respeito, apagando sua origem incerta e talvez bastarda. Se levarmos em conta que ele se ressente de ter sido "bastardo", também deve ter ressentimentos do velho Salustino e do filho. O Padilha provavelmente, enquanto estudava, através de "economias indecentes", é

\footnotetext{
${ }^{92}$ Citado em MARX, Karl. A Origem do Capital: A Acumulação Primitiva / São Paulo: Global Editora, 1979. (Cf. p. 124, nota 4)
} 
tido como o responsável pelos "tostões" que recebia do velho Salustiano. A partir daqui, poderemos analisar os capítulos subsequentes com mais acuidade. Levando em consideração dados que revelam Paulo Honório com traços de um mundo que atravessa o mundo burguês de forma silenciosa e que aí está.

Uma das questões mais importantes para Graciliano Ramos, no labor de construir um romance, sempre foi a de justificar minuciosamente cada detalhe de suas histórias. Era algo, para ele, quase que de "ingênua infantilidade" o fato de que os romancistas brasileiros

(...) ocupados com a política, de ordinário esquecem a produção, desdenham o número, são inimigos de estatísticas. (...) Lendo algumas novelas, temos o desejo de perguntar de que vivem as suas personagens. (...) Um cidadão é capitalista. Muito bem. Ficamos sem saber donde lhe veio o capital e de que maneira o utiliza. Outro é agricultor. Não visita as plantações, ignoramos como se entende com os moradores se a safra lhe deu lucro. O terceiro é operário. Nunca o vemos na fábrica, sabemos que trabalha porque nos afirmam que isto acontece mas os seus músculos nos aparecem ordinariamente em repouso. (RAMOS, 1975: p. 254)

A crítica de Graciliano nos alerta para seus próprios escritos. Por isso, o capital primitivo necessário aos desígnios de Paulo, narrado no capítulo 3, é obtido de modo peculiar e de importância vital para o entendimento de seu "ser":

A princípio o capital se desviava de mim, e persegui-o sem descanso, viajando pelo sertão, negociando com redes, gado, imagens, rosários, miudezas, ganhando aqui, perdendo ali, marchando no fiado, assinando letras, realizando operações embrulhadíssimas. Sofri sede e fome, dormi na areia dos rios secos, briguei com gente que fala aos berros e efetuei transações comerciais de armas engatilhadas. (P. 14)

Eis aí o aprendizado e a reprodução do mesmo. No capítulo 4, em que conta detalhadamente o método de obter São Bernardo, é decisivo realmente o estratagema expansionista que vai engendrando. Não se deve ater, na verdade, aos detalhes da trama superficial das operações comerciais entre ele e Luís Padilha: o encadeamento do jogo sedutor de que lança mão a fim de ludibriar o até então dono de São Bernardo é de todo explícito, por isso quase nada há que nos mostrar os negócios de Padilha e Paulo, senão seu conhecimento de que o filho do proprietário estava acostumado a receber o dinheiro do pai, na cidade, e de que ele desconhecia completamente a sua forma de circulação num ambiente de produção praticamente feudal: "Mostrei generosidade: trinta e cinco. Padilha endureceu nos cinquienta e cinco, e eu injuriei-o, declarei que o velho Salustiano tinha deitado fora o dinheiro gasto com ele, no colégio. Cheguei a ameaçá-lo com as mãos” (p. 25). 
Apesar de Paulo Honório ir revelando o ressentimento guardado em função de o velho Salustiano ter investido na educação do filho, é importante o desencadeamento subsequente e previsto pelo personagem principal já nas "negociações" com Padilha a partir do endividamento dele e a posterior aquisição da propriedade: o que é nada menos que um projeto extraordinário de conquista da influência nos arredores da fazenda; muito além dos limites da fazenda São Bernardo, um projeto que incorpora tudo que é limítrofe à propriedade e, consequentemente, todo poder de sujeição que dela poderia extrair a partir da compra como forma de "desprestígio" do "coronel/chefe local".

Quando o personagem diz que seu fito na vida foi adquirir São Bernardo e em suas terras introduzir determinada tecnologia de produção etc., ele o faz de modo sintético, ligado ao senso comum: o que ocorre no seu plano e ações, de fato, é de dimensão titânica para quem teve origem "no pó". A propriedade representa internamente uma compensação moral, contudo fora dos padrões de pensamento comum; e, mais ainda nesse ambiente, um poder além do seu valor de uso ou de troca e produção de riqueza. Daí o desafio de conquistá-la, investigando sua vizinhança e localizando sob o controle de quem estava esse status. Ele estava nas mãos do Mendonça, no campo, e do agiota Pereira, na cidade, dividindo-se o restante dele entre outros pequenos chefes políticos fronteiriços a São Bernardo e em alguns setores burocráticos.

Mas destes dois "grandes momentos" o que vai contar e decidir tudo é a "questão", primeiro com o Mendonça, no campo; depois, com o Pereira, na cidade. E isso é anterior ao endividamento do Padilha: "Passei uma semana nesse jogo, colhendo informações sobre a idade, a saúde e a fortuna do velho Mendonça. Quando me decidi [a comprar São Bernardo], sujeitos prudentes juraram que eu estava doido" (p. 19).

É para demonstrar definitivamente que também se havia tornado o cabra bravo, violento, temido, que devia provar definitivamente que sua estirpe era superior. A partir dos desfechos vitoriosos nessa batalha, adviriam a sua fortuna e a sua influência, como proprietário, e a prova de suas suspeitas relacionadas à “certidão de nascimento". Vejamos isso. Vencido o Padilha no capítulo anterior, narra-se o seguinte nos primeiros parágrafos do capítulo 5:

O senhor andou mal adquirindo a propriedade sem me consultar, gritou Mendonça do outro lado da cerca.

- Porquê? (sic) O antigo proprietário não era maior?

- Sem dúvida, respondeu Mendonça avançando as barbas brancas e o nariz curvo. Mas o senhor devia ter-se informado antes de comprar questão.

- Eu por mim não desejo questionar. Creio que nos entendemos. 
- Depende do senhor. Os limites atuais são provisórios, já sabe? É bom esclarecermos isto. Cada qual no que é seu. Não vale a pena consertar a cerca. Eu vou derrubá-la para acertarmos onde deve ficar. (pp 26 e 27)

Esta é a primeira contenda, referente às fronteiras de Bom-Sucesso e São Bernardo; note-se que os tons do diálogo dos dois personagens se equivalem em peso; e pouco têm a ver com "o espaço físico" legítimo entre as fazendas: é o poder de fogo, "negociar de armas engatilhadas", que vai contar favoravelmente ou não para que se torne produtiva a fazenda, e Paulo estava disposto a arrancá-lo de Mendonça antes mesmo de ter garantido a posse definitiva de São Bernardo, antes mesmo de ter emprestado dinheiro ao Padilha. Este, no caminho de Paulo, não era empecilho: resolvia-se por operações de mercado, segundo as leis da agiotagem, e por ser perdulário.

Com o Mendonça, não se tratava de comprar uma fazenda, mas sim de "uma questão", em que os limites simbólicos do poder seriam tocados nas mudanças de limites geográficos, marcando para o protagonista a mudança de status. É a partir da alteração simbólica dos limites geográficos que a respeitabilidade se funda, por isso o Mendonça teria que mover novamente a cerca. Portanto, a entrada brusca do capítulo 5, narrando o diálogo entre Paulo Honório e Mendonça, não é fortuita: estava prevista, e sua imediaticidade é traço da gravidade do problema. A partir da contenda sobre a cerca da fazenda, desdobra-se verdadeira tática de guerra entre os dois rivais.

Voltemos ao "cenário" da altercação entre Paulo e Mendonça, que beira a agressão: "Contei rapidamente os caboclos que iam com ele [diz o protagonista], contei os meus e asseverei que a cerca não se derrubava. Explicações, com bons modos, sim; gritos não" (p. 27) O outro deixa o local: "Mendonça, de longe, ainda se virou, sorrindo e pregando-me os olhos vermelhos" (p. 28) e Paulo continua estirando arame farpado no reparo da cerca.

Após consertar a cerca, deixa também o local com Casimiro Lopes: “(...) acompanhou-me, carrancudo. Como eu dissesse nada, tossiu, parou”. "Tossir" é uma função aí, chama a atenção do patrão que imediatamente dá as ordens; atente-se: Casimiro não pode dar ordens, por isso tossiu, um modo de dizer sem interferir no poder de mando daquele que o detém pela palavra: “(...) Amanhã traga quatro homens, venha aterrar este charco. E limpe aqui o riacho para as águas não entrarem na várzea". Casimiro responde perguntando: "Só??". Paulo pensa em outras atividades necessárias e Casimiro reforça: "Só??". A pergunta de Casimiro Lopes é semanticamente investida de outros sentidos, não é pergunta necessariamente, cuja compreensão o proprietário revela depois: “Apanhei o pensamento que lhe escorregava (...) era 
preciso mexer-se com prudência, evitar as moitas, ter cuidado com os caminhos. E aquela casa esburacada, de paredes caídas..."

Os termos assinalados estão todos imanentes na pergunta de Casimiro Lopes, dando início a um longo percurso de funções e índices com significados de "espreita", "cilada", "tocaia" etc. Também, dialogicamente, da interpenetração que ambos têm na consciência um do outro: ambos são capazes de atravessar a palavra que conduz ao mundo de valores simbólicos e de relação social por ela abafados. E é nisso que pensa Paulo Honório, quando diz no último parágrafo deste capítulo: "Diabo! Agitei a cabeça e afastei um plano mal esboçado. Por enquanto, só”. Paulo Honório não muda de ideia, porque isso aludiria pouca segurança no tocante ao que deveria ter decidido, como chefe, e ordenado.

O que parece ter um significado no "plano frontal" do enredo, em outro nível nos mostra outro sentido: São Bernardo representa a singularidade de um universo desconhecido. Daí em diante, vamos observar acontecimentos aparentemente fortuitos, cujo tratamento é de certo modo natural. Paulo Honório compreende o plano esboçado por Casimiro Lopes, mas não dá "contra-ordem", isto é, não modifica a primeira ordem dada de aterrar o charco e limpar a várzea. Tivesse feito isso, a ordem não seria dele e o poria numa situação em que o processo de desordem poderia acontecer.

A interpenetração, através da palavra, de um e de outro, na forma como opera a consciência, revela uma rede de relações localizada e compartilhada numa esfera social e quais os seus valores. Paulo Honório, Casimiro Lopes, a velha Margarida, o Mendonça, entre outros, apresentam essa capacidade de interpenetração e antecipação das consequências do pensamento e da decisão advinda dele. Segundo cada uma das decisões e ações é que toma vulto o status de cada um. É uma relação baseada noutro tipo de valor moral. Que, por exemplo, a palavra "assassino" anula pela perspectiva de valor moral ancorada na esfera burguesa ou liberal de relação social. O Jaqueira, segundo essa esfera, é um assassino. Mas, na esfera de relação social "não-burguesa", sua ação é "honra" e respeito. 


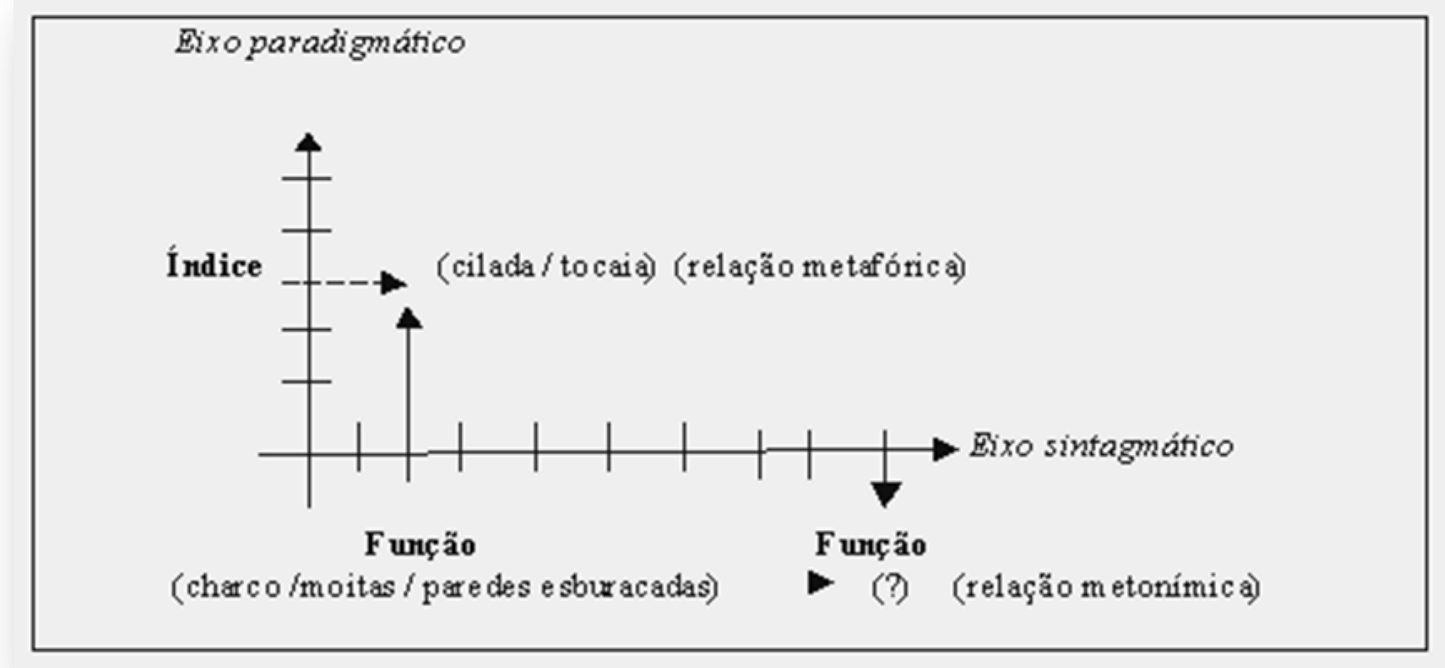

Neste plano, já vemos se esboçar uma espécie de "sincretismo" entre Paulo e Casimiro Lopes: ambos reagem juntos. Há certa convergência dialógica, assinalada no monossilabismo de Casimiro, que os faz conhecedores do universo interior um do outro. Mas o comando é do personagem principal: "Pensei que, em vez de aterrar o charco, era melhor mandar chamar mestre Caetano para trabalhar na pedreira. Mas não dei contra-ordem, coisa prejudicial a um chefe". (cf. p. 28). Ou seja, não decepcionou Casimiro, como se o protagonista estivesse em uma prova em que a dúvida seria sinal de pouca determinação ou segurança de si necessárias como virtude a um chefe para não pôr em risco seus comandados. Isto é, os papeis poderiam inverter-se, já que o que pensou Casimiro tornar-se-ia a ordem, o que o levaria a debandar para o outro lado da cerca, no sentido simbólico do poder legítimo localizado $^{93}$.

Não se trata mais de relação passível de análise por meio de categorias econômicas marxistas, apenas. Elas dão conta do jogo superficial das relações, mas tornam impenetráveis outras cuja compreensão não alcançaríamos. O poder do capital não basta para impor o proprietário; o poder simbólico estaria sob a base de outras possibilidades de poder e prestígio

\footnotetext{
${ }^{93}$ O princípio que regula as atitudes de Casimiro Lopes e Paulo Honório foi explorado ostensivamente por João Guimarães Rosa em Grande Sertão: Veredas. Ver os episódios em que Riobaldo torna-se chefe, muda o nome para Urutu-Branco e sente-se ameaçado, no comando dos jagunços, pela concorrência de Zé Bebelo. Suas ordens não podem ser questionadas. E ao dar ordem de que havia-se de matar o primeiro que aparecesse pela estrada, vê-se na mesma situação de constrangimento em que se encontra Paulo Honório: “(...) porque eu não podia voltar atrás na promessa de minha palavra declarada, que os meus cabras tinham escutado e glosado." ROSA, João Guimarães. Grande Sertão: Veredas / Rio de Janeiro: Nova Fronteira, 2001. (Cf. p. 490)
} 
dos quais depende a compreensão de outro modo de conceber as relações sociais, fora dos padrões morais ou éticos burgueses do liberalismo. Entre Casimiro e Paulo Honório está estabelecida uma relação de pacto, pelas palavras declaradas e pelos atos, que os faz cúmplices de uma forma de poder exercido fora do contrato "patrão/empregado" (em que se pode dar ordens e contra-ordens sem que isso interfira no status de poder do proprietário).

Ele correrá o risco de mandar trabalhadores a uma área perigosa (mestre Caetano e os cavouqueiros) para não perder o controle de seus jagunços. Irritado por não ter imaginado antes o que Casimiro previa, pensa: "Diabo! Agitei a cabeça [gesticulando-a negativamente em sinal de reprovação a si mesmo] e afastei um plano mal esboçado.” A fim de contornar o plano de Casimiro, encerra o episódio com um "Por enquanto, só."

Saímos do primeiro ano e entramos, no capítulo 6, no segundo. Paulo Honório revela que já conhecia o Mendonça desde a infância: “(...) lamentei a morte da mulher, excelente pessoa, caridosa, amiga de servir, sim senhor. Mendonça, espantando, perguntou onde eu tinha visto d. Alexandrina. / - Faz tempo. Fui morador do velho Salustiano. Arrastei a enxada, no eito." Seria d. Alexandrina a madrinha dele, não mencionada? Mendonça, dizendo que "trabalhar não era vergonha", rebaixa Paulo Honório, afirmando que se tivesse tido a mesma origem não negaria. Ora, a ideia de rebaixamento por nascimento e origem "ingrata" está sempre nos tons dos diálogos, manifestada na certidão de nascimento como inferioridade, na história do Jaqueira... E Paulo Honório, embora se contenha, parece querer revelar is so como forma de dizer que estava ali de volta a fim de reparar a vergonha, como se tivesse sido afrontado. As características de segredo despontam ali e acolá como pequenas pistas: Mendonça destaca que "ser trabalhador" não é vergonha. Mas, ao separar-se de Paulo Honório pela origem, indica que as "características do dono de São Bernardo" supõem sua bastardia: "A idade, o peso, as sobrancelhas cerradas e grisalhas, este rosto vermelho e cabeludo têm-me rendido muito consideração. Quando me faltavam estas qualidades, a consideração era menor" (p. 12).

Desde o encontro com Mendonça, a recorrência de termos ligados a noite ou a não dormir abundam na narração: "Trabalhava danadamente, dormindo pouco, levantando-me às quatro da manhã", diz Paulo (p. 29). "Tubarão ladrava lá fora e nós aguçávamos os ouvidos" (dentro da casa de Paulo Honório, o que constitui parte do "trabalho" ou é encarado como trabalho). E, na visita que fizera ao Mendonça, na casa do adversário, revelando sua origem de trabalhador alugado, notam-se os seguintes aspectos: "Despertou. Bocejando, mostrando 
os caninos amarelos e pontudos, Mendonça bateu palmas e esfarelou um mosquito. Mosquito como bala! Tinha passado uma noite terrível." (p. 30). "Respondi que havia dormido como pedra" (dissimula Paulo) (p. 31). As aparições da ideia de "não dormir" se unem, mais tarde, à repetição de "tiros" durante as divagações do personagem pela fazenda (como se esses tiros fizessem parte da paisagem):

Subi a colina. Tinham-se concluído os alicerces desta nossa casa, as paredes começavam a elevar-se. De repente um tiro. Estremeci. Era na pedreira, que mestre Caetano escavacava lentamente, com dois cavouqueiros. Outro tiro, ruim: pedra miúda voando. (p. 32)

(...) Mais tiros na pedreira. (p. 33)

O que se passa, tanto à noite quanto de dia, de modo invisível, é parte de toda trama do poder: esses tiros que deixam seus rastros de "pedra miúda voando" destinam-se a ele. É uma guerra, meia jagunça, entre coronéis, que se vai travando enquanto a implantação do modo capitalista industrial-agropecuário vai sendo introduzido ali. Coisa de que a crítica jamais tratou e por isso, dizíamos, analisou o romance dum único ângulo: exatamente conforme Álvaro Lins, a partir do aparecimento de Madalena.

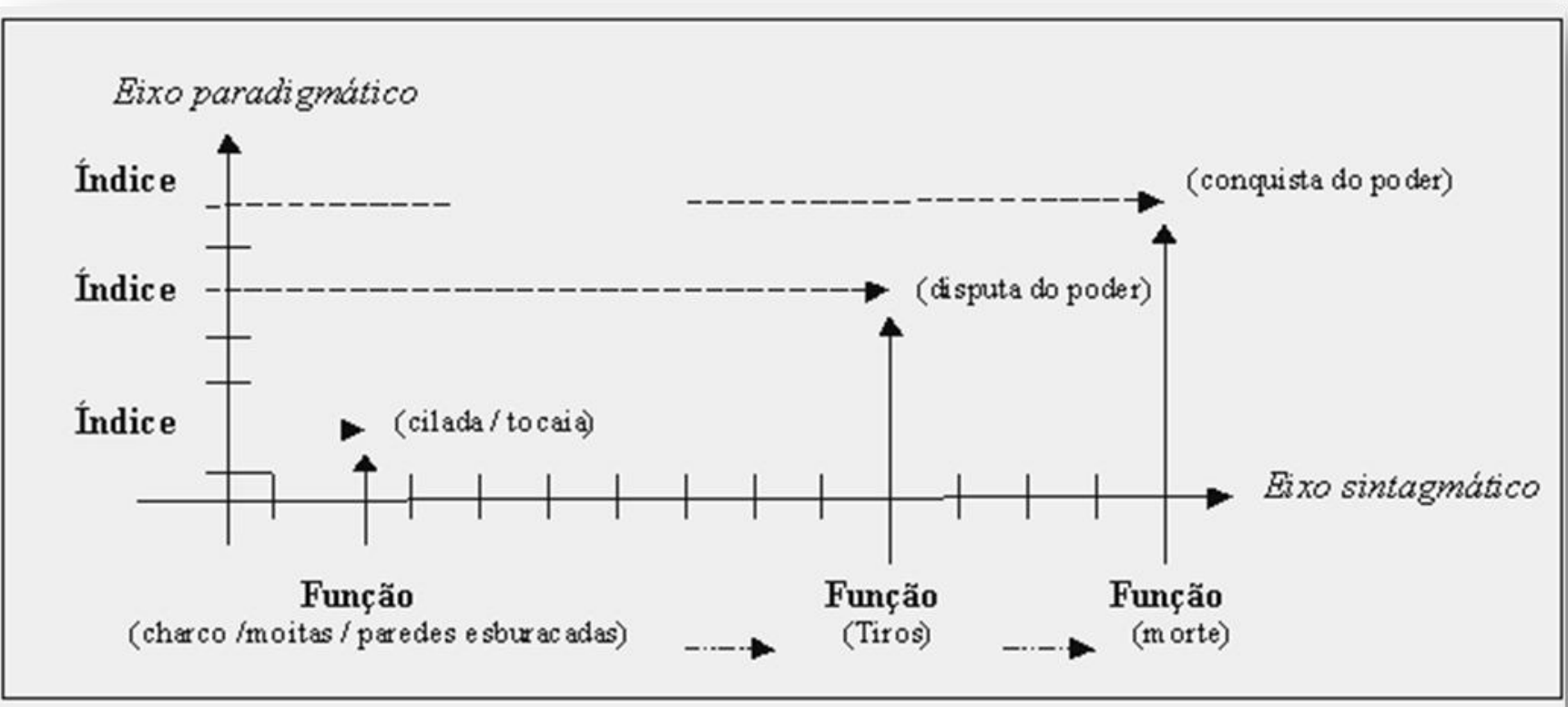

No fim deste capítulo, ocorre a morte do Mendonça. Mas em nenhum momento do romance se fala em "tocaiar" ou "assassinar", tampouco a ordem de assassínio é dada verbalmente. Por fim, a morte de Mendonça é o início do expansionismo territorial e influência 
política que vai indexar à personalidade de Paulo mais uma certeza daquela face 1 identificada no primeiro capítulo e no terceiro:

Na hora do crime eu estava na cidade, conversando com o vigário a respeito da igreja que pretendia levantar em S. Bernardo. Para o futuro, se os negócios corressem bem.

- Que horror! exclamou Padre Silvestre quando chegou a notícia. Ele tinha inimigos?

- Se tinha! Ora se tinha! Inimigo como carrapato. Vamos ao resto, padre Silvestre. Quanto custa um sino? (p. 34)

Lembremo-nos, antes de avançarmos, de que o nível paradigmático é fundamentalmente o nível do "ser", dos índices. Observando o gráfico anterior, notamos que, conforme as ações operam-se, no nível sintagmático, nível do "fazer" ou das funções, evidenciam-se transformações específicas no "ser" do personagem. Ele transita do alto sertão à Zona da Mata, e, ao passar a interagir com o mundo da cidade, levará consigo o mesmo arsenal de convicções que o levara de trabalhador do eito a chefe/proprietário. Perceba-se, portanto, que, desde sua origem, a cada episódio em seu desenvolvimento "existencial", incorporam-se nele novas modalidades de "conhecer/acreditar", "ser" e "fazer". Tudo isto é de extrema relevância para a leitura dos dados que ora operamos. Por isso, ao refazermos o percurso narrativo, um "personagem" e seus mais recônditos segredos se nos oferecem aos olhos.

Paulo Honório torna-se um proprietário imoderado, conforme o padrão estabelecido pelo ambiente de relações; e, para que se mantenham em bom andamento "seus negócios", conforme refere, foi-lhe necessário agir consoante a regras específicas:

\footnotetext{
Depois da morte do Mendonça, derrubei a cerca, naturalmente, e levei-a para além do ponto em que estava no tempo de Salustiano Padilha. Houve reclamações.

- Minhas senhoras, seu Mendonça pintou o diabo enquanto viveu. Mas agora é isto. E quem não gostar, paciência, vá à justiça.

Como a justiça era cara, não foram à justiça. E eu, o caminho aplainado, invadi a terra do Fidélis, paralítico de um braço, e a dos Gama, que pandegavam no Recife, estudando direito. Respeitei o engenho do dr. Magalhães, juiz. (P. 40)

E decidi proteger as Mendonça. Minha prosperidade começara depois da morte do pai delas. (...) Senti pena das Mendonça. Mandaria no dia seguinte dar uma limpa no algodão de Bom-Sucesso, enfezado, coberto de mato. Muito por baixo as Mendonça. (P. 45)
}

O fato é que, antes de Paulo, o mundo já era do modo como ele o encontrara. Para de vez estabelecer sua supremacia, reproduz o mesmo modelo de relação: provavelmente ele conhecia os limites originais da fazenda; avançar os limites sobre as terras do Mendonça aplainou o caminho para avançar sobre os outros, já que se constitui a conquista de um "poder" determinado pela audácia da mudança de limites, que estava nas mãos do outro, e que passou 
às suas (ele não é só um capitalista). As atitudes que a crítica lhe cobra devem ser avaliadas com cautela: há certo simplismo nelas por ver no personagem um burguês genuíno, de um lado, e, de outro, um assassino tão somente. É verdade que a leitura de um trecho como esse nos causa a maior repugnância. Mas se nos deixamos levar pelo efeito de indignação, deixamos de compreender os elementos que o produzem, sendo centrifugados pela leitura.

Vale antecipar em que medida se percebe esta "falta de ética" no desenrolar das ações do personagem principal, já que ela se contrapõe a um modelo de pensamento que ali em São Bernardo não existe. Facioli, com qual concordamos em muitos aspectos, por exemplo, dizendo que “(...) o problema de Paulo Honório é sua incapacidade de modernizar-se socialmente, embora ele tenha sido um excepcional modernizador econômico (...)" (P. 56), não percebe que o "econômico" está emaranhado a concepções de poder das quais não se poderia deixar de prescindir nesse ambiente de produção e que nada têm a ver com um processo capitalista, unicamente. As relações que ele mantém com o mundo rural não podem ser mudadas porque falta ali um contrato burguês de relação e poder instaurado pelo aparelho do Estado: é a ausência deste último que impede modernizar-se socialmente. Vide a consciência de Paulo Honório de que, "como a justiça era cara", as Mendonça não iriam à justiça (as leis da cidade inexistem no mundo sertanejo, substituídas pela lei da violência e do banditismo). Bilateralmente, ele atrelará essa relação ao mundo do domínio da cidade (aí confundido o que se faz por contrato com o pacto simbólico do sertanejo com a palavra, o ato, o privilégio reconhecido numa espécie de trajetória heróica ou de bravura e honra sertaneja). Mas a cidade não deixará de ser cúmplice da manutenção do atraso representado nestes capítulos. 


\section{As ilusões do romance}

Seu Ribeiro desdobrou a Gazeta. Instintivamente escondi-me num canto, afastado das portas abertas. Não consegui evitar uma janela. Quis fechá-la, mas sosseguei: Casimiro Lopes, que vigiava a casa, sentou-se numa das paredes começadas da igreja, acomodou o rifle entre as pernas e ficou imóvel, farejando. (p. 50)

Foram necessários cinco anos para que São Bernardo rendesse ao protagonista toda influência e prosperidade que almejava. Após a morte do Mendonça, contrata-se um guardalivros; os primeiros amigos influentes começam a frequentar a fazenda: padre Silvestre, dr. Nogueira, o jornalista Gondim. Derrotado o adversário mais perigoso, avança. Há outros, contudo, motivo de qual, enquanto Honório se reúne com seus convidados, Casimiro guardar sentinela. O que indica que a guerra é contínua, caracterizada como parte do trabalho de um proprietário/chefe-jagunço nestas circunstâncias (mesmo depois da morte do Mendonça, Paulo leva um tiro de tocaia).

$\mathrm{Na}$ instância enunciativa, o ocorrido com o narrador já é o mesmo que ocorreu a seu Ribeiro: certa inadequação ao mundo moderno burguês, gerando o efeito irônico do romance: a modernização e socialização são parciais, insuficientes para elevarem-no em termos de classe e consciência: sua ascensão, na esfera do mundo burguês, é única e exclusivamente material. É nesse sentido que o Brasil tratado por Graciliano ainda não o havia sido até então: antes dele, as relações apresentavam-se sob o ângulo de visão da cidade em detrimento do ângulo do homem do campo, projetadas a partir de categorias de pensamento incapazes de satisfazer a complexidade de sua concepção.

Período extremamente fecundo para nossa ficção, os anos 30/45 mostram a confluência das mais diferentes tendências literárias. Como inovação, avulta o romance regionalista que, engajado na denúncia da Injustiça Social, revela aos brasileiros um Brasil "medieval", praticamente desconhecido da maioria: o Brasil do Norte/Nordeste, acossado pela seca, pela miséria e pela exploração dos poderosos latifundiários. ${ }^{94}$

Quando Paulo se reúne aos seus aliados novos, fica sabendo das reviravoltas ocorridas com o candidato às eleições: padre Silvestre, apoiado pelo agiota Pereira, de quem já dissera ter-se vingado. Pressente a oportunidade de realizar sua segunda meta: após vencer a "questão Mendonça", fica sabendo que o agiota perdeu a influência e pretende atingi-lo no momento de fragilidade: “O que eu não compreendo, estranhei, é a razão dessa rasteira no

${ }^{94}$ NOVES COELHO, Nelly. Literatura e Linguagem: A obra literária e a expressão lingüística / São Paulo: Edições Quíron, , 1986. (Cf. p. 259) 
vigário [diz Paulo Honório aos convidados]. Estava quase eleito, reconhecido, empossado, e de repente - zás! - No chão. Porque (sic) foi?” (Cap. 9) Dr. Nogueira explica a Paulo Honório que o padre era revolucionário. Então fica confirmada para Paulo Honório a queda do agiota: “(...) essa história da queda do Pereira é certa? João Nogueira aceitou um charuto e declarou que não havia dúvida nenhuma". Aí fecha o diálogo:

- Pois, dr. Nogueira, murmurei abafando mais a voz, cuido que chegou a ocasião de liquidar os meus negócios com o Pereira. Tenho marombado, espiado maré, porque o chefe era ele. Mas se foi ao barro, acabou-se. Está aqui enrascado numa conta de cabelos brancos. Vou entregar-lhe a conta. Veja se consegue uma hipoteca.

- Perfeitamente! concordou João Nogueira. E entusiasmou-se:

- Perfeitissimamente!, passe a procuração. O senhor vai prestar ao partido um grande serviço. Aperte o Pereira, seu Paulo Honório. (P. 55)

Vencido o chefe/coronel no campo, quebrado o elo com o chefe/político na cidade, Paulo Honório, pela vingança, chegara à esfera do poder do modo como ele se institui no Brasil Colônia. E é no capítulo 12 que vai ser amarrado definitivamente esse nó. O empréstimo e endividamento de Padilha e Pereira representam apenas a superfície da relação capitalista, escondendo no seu bojo um modo de interação social nada adequado ao modelo burguês liberal.

Enquanto com Mendonça mediu a força da violência, com o Pereira medirá a força do capital para vingar-se. E, na casa do juiz dr. Magalhães, com o intuito de que ele desse ganho de causa para a hipoteca das propriedades do Pereira, tinha em mente, ainda, casar-se com a filha do juiz; meio de ampliar seu domínio, visto que o engenho do dr. Magalhães fora o único não invadido:

A questão do Pereira estava dormindo no cartório, esperando que o juiz de direito desse uma penada nos autos. Eu então, ligando o caso do Pereira aos predicados de d. Marcela, desci no dia seguinte à cidade, resolvido a visitar o dr. Magalhães. ( p. 64)

O casamento com a filha do dr. Magalhães, enquanto pacto familiar, ampliaria o raio de sua influência: de "São Bernardo" a toda sua volta, conectado o poder legal do juiz de direito, seu status, ao poder simbólico de chefe sertanejo. Por mais curioso que isso seja, essa trajetória que vai realizando Paulo Honório não é algo fortuito nem tem origem em sua sede de prosperidade, sentimento de propriedade ou ganância, somente, nem mesmo tem origem na sua sede de vingança. Tal trajetória é mais antiga do que supomos. Começa no processo de 
colonização do Brasil no século XVI e se estende até nossos dias, pelo menos enquanto mentalidade desenvolvida:

\begin{abstract}
Casamento era uma aventura comercial tanto para os juízes quanto para as famílias coloniais. Além da satisfação de certas necessidades sociais, sexuais e psíquicas, o juiz procurava posição econômica enquanto a família esperava incorporar o poder, o prestígio e o status do desembargador na teia familiar. Em outras palavras, havia uma troca de recursos com expectativas de reciprocidade e esperança mútua de obter vantagens. ${ }^{95}$
\end{abstract}

Tais conexões do poder, nos primeiros séculos da colonização, eram recíprocas. A rede de relação que permeia a ascensão de Paulo Honório tem caráter histórico no Brasil. Em São Bernardo, este é o ponto máximo da escalada do protagonista. É neste momento, no capítulo 12, na casa do juiz, que ele conhece Madalena. E sua mudança, ao que parece, ficou "desconhecida de si mesmo": abre mão, por ora, de seus desígnios misteriosos de "vingança" e prosperidade material.

Naquele momento, porém, como já disse, conservavam-se todos em silêncio. D. Marcela sorria para a senhora nova e loura, que sorria também, mostrando os dentinhos brancos. Comparei as duas, a importância da minha visita teve uma redução de cinqüenta por cento. (p. 64)

E aí se chega ao momento em que ele comete seu primeiro "ato falho", inconscientemente: a redução do lucro representa um simbólico acréscimo a ele de algo aparentemente sem valor, ou que não pode ser mensurado; não porque não sabia o que estava fazendo, mas porque o desconhecia ou julgava poder controlá-lo - como ele mesmo disse, a importância de se casar com d. Marcela representava um lucro (superfície), sendo ela herdeira do engenho do dr. Magalhães (simbólico), e outros cinquenta por cento que se ligariam ao julgamento favorável do juiz ao processo de hipoteca das propriedades do agiota (subjacente/vingança). Com Madalena ele só teria a garantia da permanência de sua fortuna em família, ou seja, o herdeiro de seu "império", já que, "parece-lhe”, ter-se apaixonado não tinha nenhum valor e, neste caso, só lhe daria despesas, não mais o lucro de casar-se com a filha do juiz.

Há uma verdadeira concessão aos "sentimentos", portanto, no sentido genuinamente romântico, que ainda não havia ocorrido a ele: o que manifesta à velha Margarida é gratidão e também oportunidade de se reestabelecer em seu lugar de origem/honra (donde o nome Honório). Nenhuma certeza o adverte a respeito da "inutilidade sentimental" ou dos perigos

\footnotetext{
${ }^{95}$ SCHWARTZ, Stuart. Burocracia e Sociedade no Brasil Colonial / São Paulo: Ed. Perspectiva, 1979. (Cf. p. 142)
} 
da afetividade, como a advertência que ocorre através da voz da velha Margarida em relação à "inutilidade da generosidade" para um proprietário; ou como a que surge pela interpenetração na consciência de Casimiro Lopes. Contudo, há vozes no dialogismo desse capítulo, mas das quais ele não só ignora a origem como o significado implícito.

O que se manifesta, a partir daí, é uma espécie de idealização involuntária que vai engendrar as condições de sucesso de uma das faces aparentes do sujeito e, ao mesmo tempo, de falência da outra: do ponto de vista psicanalítico, parece que se está diante de um "outro Paulo Honório" em busca de outro tipo de "sucesso" ou "fito na vida" produzindo certas contradições em seu comportamento:

(...) se devemos pensar o sucesso do ponto de vista psicodinâmico, temos de ter em mente três coisas inevitavelmente ligadas. Em primeiro lugar, pode ser útil pensar em nós mesmos como personalidades múltiplas, em nossos mundos interiores como mais semelhantes a um romance que a um monólogo. Cada personagem, ou parte de nós mesmos, possui projetos diferentes, e diferentes critérios de sucesso $(\ldots)^{96}$

Sem que se perca de vista, nesse caso, de que essa hipótese seja exclusiva para dar conta do personagem, pois ele não é realidade psíquica empírica; nem, tampouco, da totalidade dos processos do romance. Mas podemos fazer dessa hipótese certo uso limitado que a relacione ao aspecto linguístico, discursivo e dialógico da obra e em termos literários. E um deles se dá pelo fato de que Paulo Honório não tem consciência total de tudo que aconteceu ou acontece. Seu "fito na vida", adquirir as terras de São Bernardo e nela introduzir um modelo de produção moderno, é contradito pelo tipo de realização representado no casamento com Madalena: suspendendo ou desviando-o da trajetória que o levaria ao poder absoluto com o casamento com d. Marcela.

Desde o início de sua história, Paulo Honório narra pautado por rigorosa economia quanto ao uso de adjetivos. Mesmo em relação a palavrões, diz : “(...) Quando arrastei o Costa Brito para o relógio oficial, apliquei-lhe uns quatro palavrões obscenos. Esses palavrões, desnecessários, porque não aumentaram nem diminuíram o valor das chicotadas (...)” (p. 78) Porém, na casa do dr. Magalhães, ao referir-se a Madalena, os diminutivos, “(...) cabecinha inclinada e as mãozinhas cruzadas, lindas mãos, linda cabeça.” (p. 66), denunciam em seu juízo de valor algo extraordinário: sentimento/afetividade. Os diminutivos, conferindo valor afetivo, substituem os cinquenta por cento de valor material do casamento com d. Marcela; os

\footnotetext{
${ }^{96}$ PHILLIPS, Adam - O Flerte / Companhia das Letras, São Paulo, 1998. (Cf. p. 89)
} 
adjetivos acrescem, portanto, à descrição aí, o que não acrescentariam às chicotadas no Brito alguns palavrões: uma metade desconhecida, provavelmente a que se manifesta como face 2 , dá mostras de vir à tona.

É claro que a reificação está também presente no jogo do romance; mas não apenas nele, psicologicamente, e sim no todo das relações sociais, embora superficialmente. Para o protagonista, o valor atribuído à velha Margarida não equivale às suas qualidades de mãe: ela poderia pedir o que quisesse, conformando-o ao valor relativo do mundo em que transitam e se relacionam. O que Madalena vai fazer pela velha negra, espécie de recompensa material, anula suas virtudes de ter encaminhado Paulo Honório na vida, segundo aqueles princípios por nos já analisados. Isto é, a velha negra não aceita a reificação: a materialidade do valor das roupas e lençois, quantitativamente, não compensam suas virtudes de mãe. Antes, porém, narra ele que "A senhora de preto [d. Glória] continuou sentada e entrou a discorrer sobre romances". Entrecortam a conversa das senhoras os seguintes juízos nesse momento:

- Quando julgo, anunciava o dr. Magalhães, abstraio-me, afasto os sentimentos.

- Estive comentando isso ontem à tarde com o dr. Nogueira, atalhei. [Paulo Honório] (pp. 66 e 67)

Aqui, é preciso ler entendendo por "sentimentos", no processo dialógico, o conceito imanente às convenções do gênero "romance", enquanto suposto mediador das ações morais, surgido no diálogo das mulheres na sala e atravessado dialogicamente pelo discurso do dr. Magalhães. O juiz fala de seu modo prático-racional de julgar por influência da conversa delas. E cinicamente ele despacha, aí, a vitória de Paulo Honório, num tribunal antecipado sobre a hipoteca, mediante a compra desse serviço através do advogado Nogueira. O entrecruzamento dos diálogos serve aos dois desígnios: 1) no enunciado, mostrar o desfecho ilusório do primeiro encontro com Madalena: ainda que os romances não afetem uma sociedade, em geral, eles desencadeiam num indivíduo, particular, efeitos que produzem modos de perceber a realidade subjetiva pautada pelos valores do "sentimento" dialogicamente; e 2) na enunciação, o que dali em diante provocou ironicamente em Paulo Honório tal encontro, a de sua subjetividade como a "idealidade" objetiva do mundo socializado burguês.

A fragilidade física e os diminutivos surgem de uma expectativa de que Madalena não tivesse em si as mesmas potencialidades que se encontravam nele. Paulo trai-se gradualmente, portanto, ao afirmar que suas concepções e procedimentos não se pautam pela realização afetiva ou que são destituídos de "interesses íntimos ou sentimentais": por trás da fragilidade 
aparente escondem-se perigos potencializados pelo ideal burguês, nas metáforas de "sentimento/romance", indistintos pelo modo de relação superficial do mundo burguês.

Quando deduz o valor das "mãozinhas, cabecinha e dentinhos" como igual aos "cinquenta por cento" do valor mercantil, num efeito de decréscimo, procede inversamente ao que afirma pensar: pelo menos uma parte de suas aspirações não pode ser quantificada na soma. Percebemos seu embaraço a esse respeito, quando o dr. Magalhães continua sua divagação sobre "sentimentos":

- Para proceder assim [julgar], é necessário ter independência. Que é que eles podem fazer comigo? Não preciso deles [dos romances, isto é, dos sentimentos ou dos ideais burgueses de justiça fundados num padrão ético-moral pautado pela sensibilidade]

Ignoro a que pessoas se referia o dr. Magalhães.

A trama dos diálogos ramifica-se numa rede de vozes da qual o protagonista nada pode tirar de proveito. E se a situação interna de Paulo já aparecia em conflito no nível da enunciação, intensifica-se no enunciado, numa espécie de antecipação do que vai acontecer de desconhecido na vida dele: o não saber a que pessoas se referia dr. Magalhães revela o evidente e óbvio: que, por trás da aparência, palavra, escondem-se "outros" reprimindo ou orientando (exatamente como ocorre com ele e Casimiro Lopes, em que um e outro são capazes de interpenetrar no $\mathrm{eu}$ escondido atrás da rede discursiva naquele mundo). Ou seja, trata-se de um diálogo íntimo que afeta a cada um sem que isso seja percebido (o juiz teme ser notado como alguém que não tem independência já que julga conforme a influência da parte; ao mesmo tempo quer dizer indiretamente a d. Glória ser um homem prático e racional.

Dr. Magalhães conhece a voz que fala, através dos romances, na mentalidade de $\mathrm{d}$. Glória. Isto é, a conotação do discurso, “independência para julgar”, não parte do juiz: assumiu ele esse discurso de homem prático e racionalista, quando tal concepção não advém de si mesmo justamente por agir contra o próprio juízo pronunciado (embora ele não dependa do "sentimento" para dar o ganho de causa a Paulo Honório, sua ação não é independente e lembra mesmo a dependência de aliar-se aos ricos senhores de engenho ou fazendeiros do período colonial como modo de ascensão e de prestígio dos magistrados).

Quando Paulo Honório diz não ter ideia de quem eram as pessoas referidas pelo dr. Magalhães, revela sua incapacidade de comunicar-se interdiscursivamente nessa esfera de relação social, isto é, esfera genuinamente burguesa, simbolizada pelo romance como "ideal social" ou de mundo. 
O que confunde o protagonista e o ilude é que essa metade que vai surgir simbolizada pelos cinquenta por cento de "perda material" - são os cinquenta por cento de sua condição humana, sujeita às intempéries da afeição, da dependência do afeto alheio, pelo qual haveria de reconhecer seu lugar moral e legítimo no mundo burguês através do sistema de valores implícito nos romances; lugar bem diferente daquele em que há uma espécie de "cumplicidade" coletiva manifestada por ditos populares, narrativas de façanhas "heróicas", como o caso do Jaqueira etc., que compõem a rede de valores transmitidos oralmente.

Dessa fenda aberta na subjetividade do protagonista vai surgir grande parte de um "outro ele", desorientando-se pela incompreensão do mundo em que adentra. O desdém aos romances, aos saberes, é desdém pela complexidade do mundo (de vozes, conceitos ou concepções) de qual carece, produzindo uma confiança demasiada nos meios de produção racionais, matemáticos, que o levaram à condição de grande proprietário, aos olhos da cidade, mas que representam apenas relações de superfície, escondendo a verdadeira mediação dos valores que circulam nas trocas burguesas.

Sua condição de chefe ruralista não dependeu desses valores no meio em que interagiu. Mas tudo que for desconhecido, para ele, nesse novo meio em que vai adentrando, não poderá ser explicado senão pela traição, pela desonra, pela sabotagem e, finalmente, pelo mágico ou metafísico (embora Graciliano não tenha estereotipado em demasia o personagem como um supersticioso tolo).

Sua pretensão de se casar com d. Marcela, inicialmente, era busca de um tipo de pacto, correndo sob os aspectos da relação de superfície; nada além de continuísmo do que vinha praticando, em forma de uma "rede de aliança familiar, de poder financeiro e político" tal qual no período colonial, em que

(...) o casamento era não tanto um assunto pessoal quanto era um assunto de família, e isso favorecia a família de muitos modos. O casamento de filhos, ou filhas, dava continuidade às linhagens dos dois genitores porque, no Brasil assim como em Portugal, a linhagem se transmitia tanto pelos homens como pelas mulheres. Além disso, o casamento de um filho dava a sua família como num todo uma aliança com a família da noiva $(. . .)^{97}$

Pretendendo firmar uma aliança baseada no "tipo de aliança patriarcal", a princípio, mas decidindo por um casamento moderno, pelo afeto, lançou-se numa via dupla; nem mesmo

\footnotetext{
${ }^{97}$ NAZZARI, Muriel. O Desaparecimento do Dote: Mulheres, Famílias e Mudança Social em São Paulo, Brasil, 1600-1900 / São Paulo: Cia das Letras, 2001. (Cf. p. 66)
} 
sabe avaliar isso e segue livremente ao sabor de uma intuição ilusória: Madalena não era uma mulher frágil, impulsionada por sentimentalismos, apenas, mas determinada pelo mesmo desejo que ele de construir e participar de um mundo ideal. Aquilo a que ele passa a aspirar, desde então, é outro tipo de relação, mas com a mesma finalidade do casamento estabelecido por pactos familiares e que vinha, desde o século XIX, sendo minada pelo "casamento por amor".

No pacto, há uma cumplicidade do casal, em termos de aliança familiar, e uma separação no que tange às aspirações pessoais (para manutenção do poder social e da hierarquia): foi prática normal até o tempo do Brasil Imperial que o homem tivesse uma amante, separada da relação social, segundo o modelo escravista: o senhor de escravos mantinha na família mulheres negras como simples objeto de satisfação sexual, enquanto que a senhora representava sua participação na esfera do poder social e público. A partir do movimento romântico no Brasil, inicia-se um novo modelo de família, representado amplamente pelo ideal de "nação moderna e independente", o que se comunicava através do círculo de intelectuais liberais e românticos do século XIX: "Como outros romancistas românticos, Alencar salientou em (...) seus livros o valor do casamento por amor, mas também enfatizou ser necessário que os homens deixassem de ser devassos (...)” (NAZZARI, 2001: p. 252)

Não podemos nos esquecer das origens do protagonista: representa ele o "agregado/jagunço" que, na sociedade do livre comércio, da livre competição, reverte a situação passando a "grande proprietário" como herdeiro da concepção patriarcal/ruralista, contudo, sem o ser literalmente (conforme uma filiação, mas conforme um mundo de práticas simbólicas). Não se pode falar dele como “incapaz de socializar-se” por isso: ele está plenamente caracterizado em termos de superfície e profundidade desde o início.

Numa sociedade na qual a troca de produtos é a principal atividade política, até mesmo os operários, cotejados com "o dinheiro ou [como] proprietários de mercadorias", tornam-se proprietários, "donos de sua força de trabalho". É somente neste ponto que surge a famosa auto-alienação de Marx, quando os homens são rebaixados a mercadorias; e esta degradação é característica da situação do trabalho numa sociedade manufatureira, que julga os homens não como pessoas, mas como produtores, segundo a qualidade de seus produtos. $^{98}$

\footnotetext{
${ }^{98}$ ARENDT, Hannah. A Condição Humana / Rio de Janeiro: Forense Universitária, 1999. (Cf. p. 176)
} 
Assim, há algo que se esconde nas relações sociais burguesas, de modo geral, neste romance, que se explicita nos momentos em que certos aspectos não podem ser explicados nem apreendidos em termos de relações mercantis e categorias marxistas de análise literária. Por isso, se a reificação afeta, em parte, a mentalidade de Paulo Honório, por outro lado o uso da noção afeta todo o romance: o próprio leitor acaba reificado e não enxerga mais Paulo Honório senão como exatamente define Arendt "a famosa auto-alienação de Marx". Paulo Honório não pode ser visto apenas como "proprietário burguês": ele representa um elo entre o passado histórico, iniciado na colonização portuguesa, e o mundo moderno burguês capitalista. Reduzi-lo a este último aspecto, apaga tudo que tem relação com o primeiro (simbolizado desde o capítulo 3 até o 11).

Paulo Honório não é só um "negociante", medido pelo valor do produto (propriedade) que ele adquiriu (ele faz uso dessa relação mediadora na cidade, mas não tem essa relação como modelo único de sua mentalidade e de poder no campo); é antes um jagunço que negocia, aprende com o comércio a relação social estabelecida na cidade e aplica-lhe a regra: julga na cidade sempre a partir do modelo econômico, por parecer-lhe que assim são os "homens que bebem na ribeira do navio"; mas, quanto ao sertanejo, o roceiro, o jagunço, naquela relação, sabe que o fator que determina ou mede seu valor não é o material em si. Ele é o iniciador de uma classe híbrida do antigo patriarca, identificado pelo dialogismo, unido a um tipo de "novo rico", identificado pela relação praticada na cidade. O que regulamenta suas decisões mais íntimas não se confunde com os traços superficiais de sua conduta de comerciante e capitalista. Antes hão de ser distinguidos. Se o "dinheiro", por exemplo, não resolve a questão com o jornalista Brito, vem à tona o "meio" pelo qual resolveu tais questões no alto sertão.

Paulo Honório não percebe nas transações que faz o perigo da cidade (antecipado no capítulo 7 pela história de seu Ribeiro). Está posto como o dr. Magalhães julga: não há dúvida de que houve algum tipo de troca ali que não foi puramente mercantil (embora o processo seja superficialmente de compra da justiça, ele é antigo, simbolicamente representado pelo sistema de aliança oligárquica); e, principalmente, a busca da sociedade ideal, perseguida por João Nogueira, ao dizer em suas divagações sobre o governo do país e suas leis, não faz de Paulo Honório um igual: "O que deveria acabar é o Congresso. As leis deviam ser feitas por especialistas" (p. 68). Isto é, o homem é marcadamente vinculado à sua "especialidade" produtiva, o que exclui Paulo Honório de toda participação do mundo que pensa ter adentrado. 
Não foi à toa que Nogueira quisera o romance escrito conforme a "língua de Camões". O capítulo 12 sobrepõe duas formas de conceber o mundo, seu funcionamento, suas relações, excludentes e complementares, mas que não se confundem: embora cada um dos personagens possa ser captado como um emblema complexo de ideal político, de vida, de realização pessoal etc., nenhum deles compreende esse caráter no outro, ainda que se relacionem e interajam juntos o tempo inteiro no romance. O que temos, então, é uma espécie de cubo de perspectivas redimensionando uns ao outros sem que eles possam ser compreendidos por si e em si mesmos como totalidades isoladas (diferença marcante entre o romance monológico e o dialógico teorizado por Bakhtin).

Havíamos falado em processo psicodinâmico, o que não se pode negar em São Bernardo, mas que só surge a partir desse encontro com Madalena: parece brotar um desejo de se instruir, saber de que se tratava aquelas conversas. E, naquele mesmo dia, vai reencontrar Nogueira “(...) discutindo poesia com Azevedo Gondim. Escutei uma hora, desejoso de instruir-me. Não me instruí." (P. 71) A impenetrabilidade nesse novo universo deixa um rastro bastante extenso de elementos a serem analisados. Este rastro começa com esse desejo novo de instruir-se, neste capítulo, e vai gradualmente se tornar um emblema indiscutível, tanto para ele, enquanto narrador, como para o personagem.

A grande dificuldade de São Bernardo é vencermos a repugnância produzida pelo seu personagem principal; mais ainda quando ele passa a interagir com a cidade. Vencendo-a, vamos percebendo que os outros apenas diferem dele na medida em que se valem de outros meios que não a violência física. Que diferença há entre sua violência e o ato que a torna legítima em processos jurídicos julgados sumariamente na sala do próprio juiz de direito? Ou por meio dos elogios publicados na imprensa como forma de lucrar no processo? Que diferença há entre o Nogueira, o dr. Magalhães, Brito, Gondim e Paulo Honório senão a dos meios de execução de suas ações? Ainda mais quando estão todos envolvidos no processo como elementos da rede de poder.

É evidente que as ações do Honório são condenáveis. Mas sendo as dele as de um "indivíduo isolado", que prospera conforme o padrão de relacionamento pré-existente, as ações que dão aval às dele caem em desgraça pior, porque faz delas um meio de beneficiar-se:

(...) espera-se esteja demonstrada a hipótese de que a justiça funciona também conforme a ideologia, marxianamente considerada. No caso do juiz, Dr. Magalhães, a sua expressão de integridade impressiona enquanto aparência. No entanto, revelada essa aparência, a sua integridade é destacada pelo fato de estar ao lado daquele empresário, o protagonista da estória (sic). (PINTO, 1998: p. 47) 
João Pereira Pinto percebe bem, a partir de categorias marxistas, como ocorrem as inversões do "ser"/"não-ser" e "parecer"/"não-parecer". Embora não tenha percebido que Paulo Honório é apenas do ponto de vista burguês um self made man. Eis a armadilha do romance: ele fornece perspectivas que podem ser redimensionadas a partir de outras. Mas, fixando-se a uma delas apenas, outras possibilidades "flutuam" ou são anuladas. O que confere à teoria de "realidade flutuante" proposta por Rosenthal, cujo "mundo fragmentado" compõe uma totalidade diversa do modo de apreensão realista, sentido hipotético mais próximo de acerto quanto ao romance moderno.

Ainda no capítulo das chicotadas, encontra-se com d. Glória na viagem de volta a Viçosa. Fica sabendo que Madalena é professora. Sua reação, de imediato, é ligar ao valor da formação intelectual o "lucro": "Perdoe a indiscrição, quanto ganha sua sobrinha ensinando o bê-a-bá?" (p. 76). Evidentemente a desqualifica, diz que seus trabalhadores recebem melhor salário. No capítulo 14, quando chegam à estação, encontram Madalena. E a primeira fala da moça com Paulo - confirmando a ideia de que o valor da mercadoria e o valor humano se confundem na superfície das interações - expressa-se através da seguinte frase: “- D. Marcela disse-me que o senhor tem uma propriedade bonita, começou Madalena” (p. 81).

Não poderia ter pior começo para o protagonista: tendo ele acreditado que essa forma de relacionar-se no universo da cidade não ocultava nenhum segredo interior, nenhuma espécie de realização fora do lucro, não compreenderá os motivos de eles não serem aceitos como a única regra do jogo. É o que nos explica categoricamente Lafetá:

Este fenômeno, classicamente designado pelo nome de "fetichismo da mercadoria", dá origem a uma reificação global das relações entre os homens. Medida sempre pelo mercado, a consciência humana tende progressivamente a fechar-se à compreensão dos elementos qualitativos e sensíveis da realidade. Todo valor se transforma - ilusoriamente - em valor de troca. (LAFETÁ, 2004: p. 89)

Apesar do exagero de que a consciência humana tende progressivamente a fechar-se para os valores à parte do valor mercantil (o que leva ele a acreditar que Madalena se salva do efeito "global" da reificação), de fato o conceito pode ser aplicado; evidentemente é preciso notar que esse efeito aplica-se unicamente às relações sociais e a certas esferas acomodadas: há certas características que escapam a esta regra; ainda que Madalena seja simpática com o protagonista a partir da menção de sua propriedade, que essa menção tenha ocorrido já em um diálogo anterior, e, ainda, que também ela dialogue nesses termos no acordo do casamento, tanto a sua reificação esconde ideais inapreciáveis, como é inapreciável o valor do que fez por 
Paulo Honório a velha Margarida. Assim como, veremos logo mais, o valor de d. Glória em relação a Madalena. Ou seja, a reificação abrange apenas um nível de análise, não é tão global assim como se pensava.

Vejamos a caracterização da personagem Madalena; vale notar desde já que - embora tendo educação razoável e ideais humanitários - ela não demonstra nenhuma indignação quanto a ser tratada como mercadoria ou quanto a referir-se às qualidades do outro em termos de posse. Para ela, de fato, essa relação também é parte do jogo; mas não se confunde com as realizações pessoais que busca. Afinal, Madalena, sabe-se através de Gondim, é "Mulher superior. Só os artigos que publica no Cruzeiro." (p. 85). E ainda que essa posição dela desanime Paulo - sua experiência com letrados não é das mais positivas, vide o caso do Costa Brito e suas chantagens, e o do Gondim que se oferece para desmentir (mentindo) o outro jornalista - ele continua a flertá-la. Primeiro através de d. Glória, depois em contato direto. Façamos um parênteses: parece haver quem se salve das ironias e críticas aqui? É um caso curioso de romance em que "os herois" são decididos pela atualização simpática do leitor. Quase toda a sociedade representada aí parece alvo de feroz reprovação.

(...) Paulo Honório, como já foi atrás insinuado, não era uma anomalia. Nêle (sic) a reificação apenas se prefecciona. Ela, porém, está presente no Nogueira que muda de tom de acôrdo (sic) com a "qualidade"do auditório, no dr. Magalhães que só consulta autos e leis para se transformar na imagem da múmia que tem direito a julgar, na própria Madalena que, sem entender todo o perigo que corre, transaciona no casamento. ${ }^{99}$

Exceto d. Glória, em que não há este traço, a maioria dos personagens caracterizados pela cidade mantém-se nessa relação: pensando um cubo de perspectivas, d. Glória (como a velha Margarida é para Paulo Honório) representa a verdadeira meta de Madalena. Por isso d. Glória despreza a sedução do "conforto financeiro" lançada por Honório para atrair-lhe a simpatia: "Por que sua sobrinha não procura marido?", d. Glória responde que Madalena "não é feijão bichado para andar se oferecendo" (p. 87). Paulo replica que é para "garantir o futuro". Ocorre um pequeno diálogo, nesta página, sobre o que representa o casamento. D. Glória termina defendendo a reciprocidade do casal; ao que Paulo retruca com o "manual de zootecnia”. Provavelmente a opinião de d. Glória não seja a de Madalena (pelo fato de suas

\footnotetext{
${ }^{99}$ COSTA LIMA, Luiz. “A Reificação de Paulo Honório” In: Por Que Literatura? Petrópolis: Ed. Vozes, 1969. (Cf. p. 69)
} 
ações contrariarem os ideais, representados em d. Glória, frequentemente atribuídos à sobrinha).

D. Glória, que encaminha a sobrinha na vida, representa certo ideal surgido a partir da segunda metade do século XIX - em que a instrução feminina exigida tão somente para agradar, gradualmente se tornou instrução para o mercado de trabalho e para "casamentos". Isto - explica-nos a historiógrafa Muriel Nazzari - como compensação do desaparecimento do dote na sociedade burguesa:

O novo interesse pela educação das mulheres era um tipo de proteção contra as conseqüências incertas dos casamentos sem dote. A ênfase principal (...) era que as mulheres educadas ajudariam a educar suas filhas, tornando-as mais atraentes como noivas. (...) Assim, a educação tornou-se um substituto do dote, melhorando seu valor no pacto matrimonial. (NAZZARI, 2001: p. 156)

Quando d. Glória diz que Madalena não é "feijão bichado" que dizer que seu valor, dimensionado na cultura, não a reduz à dependência do casamento como modo de ascensão. No capítulo 15, sabemos que Paulo tinha 45 anos e ela, 27. E por relação amorosa entre os dois se estabelece uma verdadeira "negociata". Paulo é direto a respeito de suas intenções, casar-se com ela. Madalena, nem tanto, mas fala com a mesma linguagem a respeito do casamento:

- Seu oferecimento é vantajoso para mim, seu Paulo, murmurou Madalena. Muito vantajoso. Mas é preciso refletir. De qualquer maneira, estou agradecida ao senhor, ouviu? A verdade é que sou pobre como Job, entende?

- Não fale assim, menina. E a instrução, a sua pessoa, isso não vale nada? Quer que lhe diga? Se chegarmos a acordo, quem faz negócio supimpa sou eu. (p. 90)

O termo "casamento" está destituído completamente de seu sentido romântico; não é possível pensarmos em outra coisa senão "negócio". Ora, o que tem a ver "ser pobre"? Perguntamo-nos. É que ela não traria nenhum dote, nenhuma vantagem financeira ao fazendeiro, nem mesmo amor, evidência de que o casamento era mero acordo entre partes, contrariamente aos ideais românticos que se disseminavam desde a primeira metade do século XIX. Enquanto para Paulo, de algum modo, "a instrução" tinha algum valor, provavelmente "encaminhar o herdeiro nas regras de bem viver" ou como meio de "afinar sua sintaxe à dela", instruir-se. E Madalena aceita seu "oferecimento" no capítulo 16, declarando francamente não sentir amor pelo fazendeiro:

- Parece que nos entendemos. Sempre desejei viver no campo, acordar cedo, cuidar de um jardim. Há lá um jardim, não? Mas porque (sic) não espera mais um pouco? Para ser franca, não sinto amor. 
- Ora essa! Se a senhora dissesse que sentia isso, eu não acreditava. E não gosto de gente que se apaixona e toma resoluções às cegas. Especialmente uma resolução como esta. Vamos marcar o dia. (Cf. p. 93)

Os papeis, neste momento, se invertem: é Madalena que trata o assunto sem qualquer sentimentalismo, embora idealize a fazenda como um locus amoenus; e Paulo, por sua vez, convicto de que assim também procede, trai-se ao dizer que "não gosta de gente que se apaixona, que toma resoluções às cegas": é exatamente o que fez, acreditando não o ter feito porque provavelmente confiou nas relações externas de sociabilidade burguesa; ou seja, involuntariamente já havia idealizado Madalena como uma parceira equivalente. Pode-se afirmar isto categoricamente pelo fato de que o casamento

\footnotetext{
Embora ainda pudesse ser e freqüentemente fosse utilizado para melhorar as perspectivas dos negócios de um homem ou de uma família, pela ampliação da rede de relações, ou por dar a um homem acesso ao crédito, o casamento por si só já não definia os procedimentos de negócios [contratos de sociedades anônimas, firmas etc.] entre parentes afins, como fazia no período colonial. (NAZZARI, 2001: p. 187)
}

O "negócio supimpa" aludido por Paulo não tem referência a nenhum procedimento comercial ou de acúmulo de bens, mas é uma troca pura e simples no nível dos atrativos de um casamento com comunhão de bens: “(...) se a esposa não trouxesse nada para o casamento, o sistema de comunhão de bens lhe era vantajoso, pois quando o marido possuía bens, ou eles construíssem um patrimônio depois de casados, ela seria uma parceira em igualdade de condições e receberia sua menção quando o marido morresse" (Nazzari, 2001: p. 232). Assim sendo, se pela linguagem de negócios eles estão de acordo no contrato, é só em termos superficiais que concordam.

Sob esse aparente modo de relação, em que estão de acordo, ocultam-se aspirações internas de realização cujas direções apontam metas opostas. Este ponto do romance nos esclarece que tipo de vantagem, senão afetiva, Paulo poderia conquistar com o casamento; e, diferentemente do que Lafetá propõe, a saber, que Madalena nega-se a "alienar-se entrando no jogo da reificação", ela entrou. Evidentemente, não foi pelo conforto financeiro, apenas, mas como meio de outra realização. O "amor", que ela francamente admite não sentir, complementaria o ideal de casamento que ela imaginava como padrão: de um lado, realizandose enquanto "ente-social", ela se ligaria à propriedade material; de outro, realizando-se enquanto "ente-humano", ela se ligaria à propriedade subjetiva da realização afetiva pessoal "amor". Ao deixar de lado esse último elemento, ela apenas assina com Paulo Honório uma 
relação de superfície, substituindo o "amor" pelo "jardim, flores, simplicidade das almas". Agora, porém, observe-se o anúncio de Paulo sobre a decisão de Madalena.

- D. Glória, comunico-lhe que eu e sua sobrinha dentro de uma semana estaremos embirrados. Para usar linguagem mais correta, vamos casar. A senhora, está claro, acompanha a gente. Onde comem dois comem três. E a casa é grande, tem uma porção de caritós.

D. Glória começou a chorar. (p. 94)

Parece que, de fato, se d. Glória não considerava a sobrinha "feijão bichado para andar se oferecendo", Madalena não compartilhava a mesma opinião ou, pelo menos, sua convicção não era sólida o bastante para mantê-la imune a essa forma de relação. E o motivo de sua decisão é a de realizar-se em termos muito curioso: "Há lá um jardim, não?" Ora, a pergunta, no momento de aceitar a "oferta", não vem senão de quem a compreendia em termos ideais: quando Paulo Honório tentou atraí-la a fim de ocupar o lugar de professora na fazenda, um pedido feito ao Gondim no fim do capítulo 14, este diz o seguinte ao protagonista: "Pois sim. Arrumo-lhe a paisagem, a poesia do campo, a simplicidade das almas. E se ela não se convencer, sapeco-lhe um bocado de patriotismo por cima."

Eis o motivo do elemento poético e convencional, surgido no segundo capítulo, da figura de "uma cigarra chiou na mata", depois, "uma coruja piou na torre da igreja" e "lembrei de Madalena". Essa "cigarra insólita", para Osman Lins, é nada mais nada menos do que a superposição de um "romance romântico" sobre um "gênero trágico". Um simbolizando Paulo Honório em certa direção, outro, Madalena, em direção oposta. E se até o capítulo 16 não temos apresentação de uma visão mais abrangente da fazenda dada pelo narrador; surpreendenos exatamente que, no capítulo 17, no dia do casamento, nos seja apresentado um quase "sumário narrativo".

Estávamos no fim de janeiro. Os paus-d'arco, floridos, salpicavam a mata de pontos amarelos; de manhã a serra cachimbava; o riacho, depois das últimas trovoadas, cantava grosso, bancando rio, e a cascata em que se despenha, antes de entrar no açude, enfeitava-se de espuma. (p. 94)

O fato de não haver descrição de Madalena ou dos convidados e da cerimônia marca esta apresentação de São Bernardo; trata-se do mesmo "tipo de alegoria" indicada na figura do chiar da cigarra: é, para o narrador memorialista, uma espécie de fala da natureza como também o é, para Madalena, confirmação de suas expectativas românticas em detrimento da realidade prática. Em contraste com os personagens, dos quais nenhuma descrição se faz, parece ser o engenho das mãos do homem o "ser vivente" de fato. Paulo diz que "Eu e 
Madalena ficamos no lado direito - e da nossa varanda avistávamos o algodoal, o prado, o descaroçador com a serraria e a estrada, que se torce contornado o morro”. (p. 95) Ela, então, fala ao marido: “- Vamos começar vida nova, hem? disse Madalena alegremente.” Começar "vida nova" tem significado irônico. Como seu consentimento em casar-se com Paulo fundamentou-se numa troca, "sempre desejei viver no campo, acordar cedo, e cuidar de um jardim", e o que vai encontrar pela frente nada tem a ver com um idílio, o processo desencadeado será de "desilusão".

A correlação feita entre o cenário, a serra florida, o descaroçador funcionando, o riacho cantando etc. e a situação interior dos personagens, no momento em que aparecerem falhados, não funcionando, não florindo, não cantando, significará a ruína interna do casal como realização pessoal. O conflito externo implicará os internos em ambos, revelando mundos ideais antagônicos. Falharão ambos por confiarem num modelo superficial sem compreender de quais condições concretas dependiam fundamentalmente. E por terem concepções antagônicas, tanto afetivas como de negócios, o desentendimento advirá daí, válido para ambos.

Ora, a implicação em termos de efeito de leitura, neste sentido, é que, conforme nossas tendências de identificar-nos com este ou aquele, o romance produzirá um significado. Antecipemos, contudo: a recepção de São Bernardo sempre se posicionou de um ângulo em que Madalena constitui-se "heroína", sendo privilegiada por partilhar conosco de princípios similares; e Honório, vilão, por representar inversão, inadequação. Efetivamente, ambos idealizam situações diferentes. Mas pesa tanto para um como para o outro a decisão tomada, segundo os moldes pelos quais cada um deles pensa as relações e as coisas do mundo; de modo algum podemos isentar um ou outro das consequências advindas de seus mundos imaginários. Muito provavelmente as sinalizações de "meio", "metade", "dois capítulos", "cinquenta por cento" fossem programáticas.

Esse é exatamente o detalhe deste romance: essa metade de Madalena que se nos apresenta apeladamente romantizada, aos olhos do leitor, é a metade que falta a Honório; e a que ele nos dá discursivamente, enquanto "homem do sertão", na sua travessia de trabalhador do eito a homem de negócios com a cidade, é o que falta em Madalena. O desconhecimento dessa metade dele por parte de Madalena, simbolizado e substituído por ela segundo as convenções do gênero "romance", produzirá o conflito. São poucos os traços dela que nos permitem corrigir a visão incompleta de Honório. É por isso que as únicas personagens que podem ser captadas de forma in- 
tegral são seu Ribeiro e d. Gloria. Esta, sim, inapelavelmente íntegra em sua dignidade, cujo contraste com a sobrinha revela ambas em posições diferentes. O choro de d. Glória representa um lamento que só se compreenderá mais à frente neste diálogo entre o casal:

(...) - Você, pelo que me disse, principiou a vida muito pobre. [diz Madalena]

- Sei lá como principiei. Quando dei por mim, era guia de cego. Depois vendi as cocadas da velha Margarida. Já lhe contei.

- Já. Lutou muito. Mas acredite que d. Glória tem desenvolvido mais atividade que você.

- Estou esperando. Que fez ela?

- Tomou conta de mim, sustentou-me e educou-me.

- Só?

- Acha pouco? É porque você não sabe o esforço que isto custou. Maior que o seu para obter S. Bernardo.

E o que é certo é que d. Glória não me troca por S. Bernardo. (p. 115)

Há clara contradição aí. Mas isso dá a d. Glória proporção adequada; proporcional à velha negra Margarida. E é só a partir do discurso de Madalena que d. Glória pode, então, ser vista como a verdadeira adversária de Paulo Honório (é d. Glória que entra a discorrer sobre romances no capítulo 12, na casa do dr. Magalhães, levando este último a trair-se). Ela é que manifesta efetivamente o que, por exemplo, Lafetá denominou em Madalena como "recusa à alienação produzida pelo capital”. Isto é,

Graciliano conseguiu suspender seu julgamento pessoal para que os julgamentos só viessem a ser possíveis [pela] compreensão em profundidade da vida de Paulo Honório. Isto não anulou o caráter de crítica social contido no romance. Ao invés disso, foi a condição para que esta crítica existisse não sob a forma de panfleto e sim numa configuração literária. A participação se alojou ao nível de linguagem e se tornou resistente ao tempo por efeito mesmo desta colocação. Do que parece se concluir: não é com a indignação que as críticas se tornam eficazes. Seria uma lei mais geral que a sua aplicação na literatura, mas que também nesta incide. (COSTA LIMA, 1969: p. 54)

Assim é apenas sob o efeito de antipatia, produzida por Paulo Honório, que Madalena incorpora os princípios morais e ideológicos localizados exclusivamente em d. Glória. E a morte de Madalena tem função nuclear no romance. É o fator que a redime de ações contraditórias e exerce atração total sob determinadas leituras, enquanto convenção do gênero literário romântico. Enquanto do ponto de vista do narrador, na enunciação, a morte determinará o "sentido mágico" do "mau agouro", produzido por "violação do sagrado", cuja busca de compreensão será a do “erro" ou "profanação" do sagrado (que Graciliano explora economicamente).

Esperamos, assim, que se tenha demonstrado, até aqui, o caráter ideológico produzido pela afetividade enquanto mediadora ou componente estético literário do gênero romântico. A ilusão por ela produzida acoberta seus princípios ficcionais. Tais princípios não podem ser redu- 
zidos à análise moral: tais análises anulam a ficcionalidade do texto e impedem a compreensão de seu caráter linguístico, literário e poético. Por isso, ao tratarmos destes personagens, antes de tudo procuramos neles perceber seus artifícios ficcionais, os valores literários e estéticos alojados na linguagem, conforme Costa Lima, como a base da compreensão que permite a crítica sociológica e não o contrário disso.

Assim, o mundo apresentado, a partir do capítulo 12, é um universo de vozes, linguagem sob matiz ideológica, que representam as consciências individuais como impenetráveis umas às outras, formando um todo meio que insondável sob o ponto de vista do indivíduo isolado. Só pela relação entre elas, consciências/vozes do discurso, é possível revelar suas afinidades e verdadeiras origens, confluências, características etc. Isso, porém, não signifique que os indivíduos (personagens) isolados, alguns, não sejam capazes de compreendê-lo minimamente. Veja-se o caso do Gondim que, ao aliciar Madalena, lança mão do discurso que é próprio dela, não dele. Evidentemente essa capacidade de Gondim depende do seu círculo de relações. E a escolha de Paulo Honório pelo romancista, conforme aqui o vemos caracterizado, não é à toa: ele é incapaz de perceber os sentidos dos discursos pronunciados e narrados por ele, evidenciando sempre sua impenetrabilidade na consciência dos outros, senão aqueles de cujas relações participa como membro.

A ambiguidade do juízo pronunciado, "Eu não gosto de gente que se apaixona e toma resoluções às cegas", dialogicamente, caracteriza relações de discursos e significados distintos conforme o ponto de vista adotado: é contraditório sob o ângulo de sua própria concepção; é irônico pela perspectiva de Madalena (ela deveria assombrar-se com esse juízo sob sua perspectiva). Ainda mais quando Paulo Honório iludiu a si mesmo. Madalena está iludida pelo fato de achar que o discurso realizado por Gondim, a fim de aproximá-la de São Bernardo, pertence a Paulo Honório: "Há lá um jardim não?" "Sempre desejei morar no campo" "Parece que nos entendemos". Ironicamente, o único que a entende, de fato, é o Gondim. E todas as ilusões produzidas no romance têm certo matiz literário, convencional, produzindo sua meta-ficcionalidade. Facilmente identificável pelo leitor que tanto pode guiar-se pela camada ilusória do texto como pela busca de compreensão dos elementos ficcionais da produção de ilusão do texto.

E o caso curioso, duma perspectiva sociológica, é que, se Paulo Honório é duplamente contraditório, Madalena é duplamente determinada. Sua realização global é determinada, primeiro, por ser um ente social, que se realiza na cultura, sem que seja anulada a realização "afetiva/subjetiva" própria do gênero feminino e determinada pelo sexo: nada impedirá que ela seja mãe. 


\section{Desilusões do romance}

Após o casamento, Paulo antecipa-nos sobre Madalena o seguinte: "Desde então comecei a fazer nela algumas descobertas que me surpreenderam. (...) Tive, durante uma semana, o cuidado de afinar a minha sintaxe à dela. (...) Tolice. Madalena não se incomodava com essas coisas". (p. 95) Mas isso a incomodava, como professora, nos outros. Isto é, o que ela não percebeu foi exatamente que Paulo Honório não diferia muito, sob este ponto de vista, dos outros moradores da fazenda. Ora, dois dias depois do casamento, Madalena toma para si os problemas dos empregados da fazenda: “(...) encontrei-a no descaroçador, conversando com o maquinista”; e, em seguida, diz ao marido que "A família de mestre Caetano está sofrendo privações". Aqui ela confere que o mundo ideal ("vida pacata do trabalhador rural") não se confirma na realidade prática. Assume ela, a partir de então, postura de quem tomou posse de um mundo, até então alheio e imaginário: quando aceita o "oferecimento" de Paulo, diz "Sempre desejei viver no campo, acordar cedo, cuidar de um jardim. Há lá um jardim, não?’. Ora, é o cenário típico dos romances de Alencar e suas heroínas. Mas, ao deparar-se com a realidade do trabalhador rural, desilude-se e imediatamente tenta reverter o quadro: “(...) a ilusão pressupõe sempre a percepção adequada, e a eventual contraditoriedade da experiência natural encerra portanto a possibilidade de ser resolvida por uma observação concordante (...)"100

Essa atitude de Madalena muita vez foi confundida com "ação política” permeada por senso de "justiça/humanidade". É romântica tal interpretação. Com base nos diálogos que tiveram antes de casarem, ela poderia pressupor a injustiça, por exemplo, no trecho, no capítulo 16, em que Paulo vai à casa de Madalena. Narra-se a "inconveniência" do Gondim que dá felicitações pelo casamento antes da hora (p. 90). Para disfarçar, Paulo fala do Grêmio Literário e Recreativo, mudando o rumo da conversa para livros. Evidentemente, o fazendeiro desqualifica a literatura, a "instrução", com o que não concordam nem Gondim nem Madalena, dizendo: "o que é desnecessário ao senhor talvez seja necessário a muitos". Reciprocidade não foi, portanto, o preceito pelo qual Madalena tomou sua decisão, noção mais ligada a d. Glória do que a ela.

O que Madalena começa a corrigir, dois dias depois do casamento, não é apenas a injustiça, mas o lugar que havia idealizado: tal lugar incluía a justiça, mas dentro dum quadro idealmente romântico e idílico (ideologia/superestrutura) em detrimento da realidade/infra-estrutura. E

${ }^{100}$ BONOMI, Andrea. Fenomenologia e Estruturalismo. São Paulo: Ed. Perspectiva S.A., 2001. (Cf. p. 24) 
curiosamente Paulo Honório também foi idealizado no episódio em que o Gondim promete ao protagonista que vai tentar convencer Madalena a ser a professora de São Bernardo. Ele é que vai falar a ela da "poesia do campo, as almas simples, jardim, flores etc." E quando Madalena diz, ao aceitar o casamento, "Parece que nos entendemos. Há lá um jardim. Sempre desejei morar no campo", acreditou ter sido "Paulo Honório" o mentor daquele discurso referido apenas ao jornalista.

Por isso ela não vê o marido nas mesmas condições de semialfabetizado nem a "alma rude". E ele acredita que ela não se importa com isso. Gostaríamos de abordar o aspecto que passa a dominar esse ponto do romance: a passagem de ser e parecer (verdade) para parecer e nãoser (mentira), consequentemente de "ser mentira" a "não-parecer" correspondente, finalmente, a "segredo". Quando Paulo encontra Madalena no descaroçador, diz ele o seguinte "Ora, muito bem. Isto é mulher. Mas aconselhei-a a não expor-se”. O que passa por sua cabeça é que

A mulher branca da casa-grande desempenhava, via de regra, importante papel no comando e supervisão que se desenvolviam no lar. (...) não diziam respeito meramente aos serviços, que, hoje, são designados domésticos. (...) mas também na fiação, na tecelagem, na costura (...) os serviços do pomar e do jardim, os cuidados das crianças e dos animais domésticos $(\ldots)^{101}$

Assim, na ilusão de que Madalena vai ser seu outro braço no trabalho da fazenda, é que ele a recomenda à cozinha, ao que ela responde que "A ocupação de Maria das Dores não me agrada. Eu não vim aqui para dormir". O trecho corresponde a uma concepção que havia da mulher do período escravocrata: “(...) a figura da mulher indolente, abandonada à rede, (...) parece ter sido mais frequente no nordeste açucareiro (...)", conta-nos Saffioti. O que, portanto, diz Madalena não corresponde ao que pensa Paulo Honório. Ao contrário, ele anima-se por ver um ser e um parecer conforme o par que almejava; mas que depois se vai modificando. As relações do quadrado semiótico, a seguir, descrevem a latência (parecer) e a subjacência (ser) ocorrendo no interior de Honório, identificado ilusoriamente em Madalena.

${ }^{101}$ SAFFIOTI, Heleieth Iara Bongiovani. A Mulher na Sociedade de Classes: Mito e Realidade; Petrópolis: Vozes, 1976. (Cf. pp. 170 e 179) 


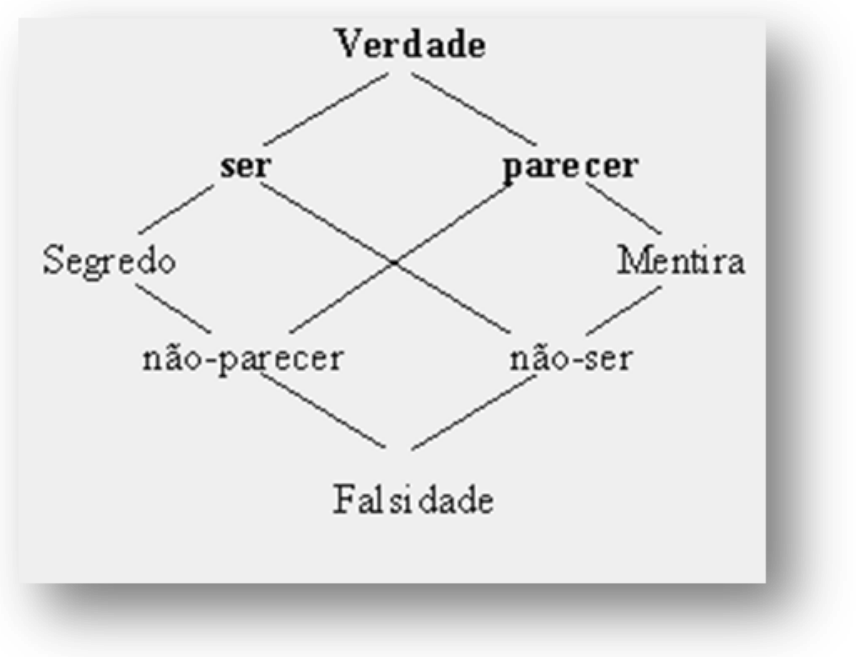

Quer casar, e casa, com uma mulher que lhe agrada e a quem está "querendo bem": mas a mulher que lhe agrada é "precisamente o contrário" do que andava imaginando, e o casamento nesses termos subverte a finalidade do projeto porque destitui a prioridade de preparação do herdeiro. (BAPTISTA, 2005: p. 109)

Abel Baptista entende perfeitamente Paulo Honório ao contrastar Madalena (em si) e o projeto do protagonista: preparar um herdeiro. E isso significa educá-lo nos mesmos termos de seu ideal de mundo; e o que começa a perceber é completamente antagônico à manutenção do poder que pretende deixar ao filho como herança. Muito embora Paulo não o mencione, é esse seu primeiro choque: sua relativa prosperidade dependeu invariavelmente de um tipo de conduta "reacionária" e "violenta" e as mudanças que Madalena pretende iniciar em seu mundo entram imediatamente em choque com "o poder simbólico estabelecido" por "elevar ao mesmo nível de possibilidades" aqueles que não poderiam gozar de seus privilégios (o que não corresponde ao mundo da livre competição e oferta da mão de obra livre no mercado; não se trata disso, mas de "semiescravidão" do ponto de vista econômico/moderno).

Recomendar o serviço "doméstico" é uma atitude, longe de ser moral, que corresponde ao distanciamento existente entre os "roceiros" e a "estirpe" do proprietário. A mentalidade de Paulo Honório é escondida pela aparência de modernização industrial implantada em São Bernardo. No fundo, a realidade concreta de produção não se modifica.

Ao contrário do conceito moderno de família e empresa, São Bernardo torna-se o lugar das duas coisas juntas, produzindo uma concepção amalgamada dos lugares em todos os sentidos. Oito dias depois do casamento, na mesa de jantar, Madalena se enternece com a situação de seu Ribeiro, guarda-livros da fazenda, ao perguntar-lhe qual o salário dele:

- Duzentos mil-réis. 
Madalena desanimou:

- É pouco.

- Como? bradei estremecendo.

(...) - Não é preciso zangar-se. Todos nós temos as nossas opiniões.

- Sem dúvida. Mas é tolice querer uma pessoa ter opinião sobre assunto que desconhece. Cada macaco no seu galho. Que diabo! Eu nunca andei discutindo gramática. Mas as coisas da minha fazenda julgo que devo saber. (p. 100)

É evidente que, para Paulo Honório, não é o valor de troca da força produtiva que está em jogo aí; mas um tipo de valor estabelecido por outra medida. E outros desentendimentos virão, mas este terá um caráter meio mágico para o protagonista: "Joguei o guardanapo sobre os pratos, antes da sobremesa, e levantei-me. Um bate-boca oito dias depois do casamento! Mau sinal. Mas atirei a responsabilidade para d. Glória, que só tinha dito uma palavra." Esse mau sinal cumulativamente vai desembocar no "mau agouro". E d. Glória, leitora de romances, mina sua importância, seu esforço, porque "cuidou e educou" Madalena segundo sua mentalidade. A “instrução” persegue Paulo Honório como uma carência dentro do universo burguês, fazendo dele, no sentido de importância, destituído de tal potencial para participar do mesmo: "Eu nunca andei discutindo gramática. Mas as coisas da minha fazenda julgo que devo saber".

Finda-se aqui o capítulo 18 como marco daquela ascensão "pacífica" em que o reconhecimento de seu lugar legítimo de "chefe" jamais foi posto em questão (ele o adquiriu juntamente com a propriedade São Bernardo, nas palavras de Mendonça). No capítulo seguinte, 19 , retoma a situação do presente da enunciação abandonada no final do capítulo 2 . Os interlocutários do narrador já não estão mais presentes. As imagens sobrepostas dão ideia de que, daí por diante, dois mundo se chocarão: o de uma aparência translúcida, do destino trágico traçado pela leitura supersticiosa do pio da coruja, "mau sinal", e o dos valores burgueses: "Uma coruja pia na torre da igreja. Terá realmente piado a coruja? Será a mesma que piava há dois anos atrás? Talvez seja até o mesmo pio daquele tempo" (p. 103).

Quando, no capítulo 20, Madalena se emprega e no 21 reivindica melhoria na escola da fazenda e, em seguida, surpreende Paulo Honório dando uns muxicões em Marciano, diferentemente do que se pensava em termos de categorias marxistas, Madalena passa a não aceitar ser "cúmplice daquele mundo". A reificação, aspecto que encobre uma prática, não tem a ver com as condições materiais de produção de existência em sua totalidade na fazenda. Estas condições devem ser lidas e distinguidas em si mesmas em seus próprios universos. 
- Marciano! (...)

- Já para suas obrigações, safado.

- Já acabei o serviço, seu Paulo, gaguejou Marciano perfilando-se.

- Acabou nada!

- Acabei, senhor sim. (...)

- Mentiroso. Os animais estão morrendo de fome, roendo a madeira. (...)

- Ainda agora os cochos estavam cheios. Nunca vi gado comer tanto. E ninguém agüenta mais viver nesta terra. Não se descansa.

Era verdade [diz Paulo narrador], mas nenhum morador me havia ainda falado de semelhante modo. (p. 108)

Enquanto o enunciador admite o fato verdadeiro, Paulo personagem associa a Madalena, à escola, tal atrevimento de Marciano (falar de semelhante modo não é característica do trabalhador rural, mas do trabalhador urbano). E será atribuído à "instrução" o mau andamento dos negócios na fazenda, a perda daquela respeitabilidade conquistada pela vitória sobre o Mendonça: em suma, estava sendo posto abaixo, como dissolução do mundo que ele conhecia e podia controlar, o poder que o mantinha absolutamente inquestionável. Mais à frente, no capítulo 23, são o "volante" e "um dínamo" emperrados; mais adiante, é “mãe Margarida” que "se queixa”: “(...) a sinhá manda tudo. Um despotismo de luxo: lençóis, sapatos, tanta roupa! (...) - Está direito, mãe Margarida. Passe bem. E saí agastado com Madalena." (p. 118).

Instaura-se entre Madalena e Paulo verdadeira disputa pelo "poder simbólico", pelo implante de valores antagônicos de organização da fazenda. Madalena vai-se tornando o elo de sua "disjunção" com o "domínio/controle do poder", que se perpetuaria pelo herdeiro. Mas sobretudo incutindo-lhe dúvidas que mais tarde serão insolúveis: "Está visto que Madalena não tinha nada com o descaroçador e a serraria, mas naquele momento não refleti nisso" (p.119). O que, porém, estava por trás do "mau funcionamento" se não era Madalena? Evidentemente, para o narrador, o elemento por trás do desconcerto do mundo, dos desentendimentos, provém da "má sorte", do azar. Mas isso vai passar por um processo encadeado no enunciado.

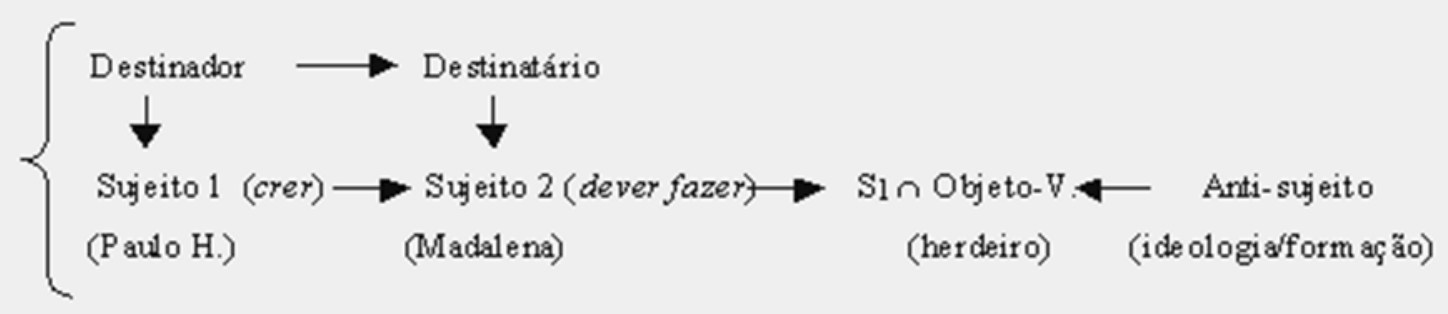


Devemos compreender, no entanto, que Madalena não é "rival" em sua totalidade; também ela é, para Paulo, objeto valor. Ocorre que, em sua individualidade, existe "ideologia antagônica" a crenças práticas do fazendeiro, pautadas pelo empirismo, utilitarismo e pela tradição ruralista, o que o leva a crer que o mundo é como é, que não pode mudar senão por forças incompreensíveis. Lembremo-nos, por exemplo, do episódio em que Padilha discursa sobre política social a Marciano e a Casimiro Lopes. Indagado, Casimiro "franziu as ventas, declarou que as coisas desde o começo do mundo tinham dono (pp. 59 e 60)". Ora, trata-se da mesma compreensão que Paulo tem do mundo (sem perder de vista que ele acredita ter algum direito aí que lhe foi tirado e que ficou em segredo).

Estamos diante, portanto, da transição do estado dos personagens: Paulo espera de Madalena um "fazer" que acredita ser o "papel dela no pacto"; ao não fazê-lo, promove no "ser" do protagonista uma espécie de descrença em andamento, contudo, não completamente; ela não pode aceitar o pacto, porque não aceita ser cúmplice daquela estrutura de poder; e, apesar de ter assinado um contrato matrimonial, não pode desfazê-lo porque, embora todo referido nos termos de uma transação mercantil, na troca burguesa, os termos do casamento não se dão conforme "um jardim, umas flores": para a mulher é puramente moral o pacto, que passa a depender terminantemente de suas decisões e ações dentro da família.

O sentido construído do nome "Madalena" sugere este sentido: está claro que ela não casou por amor; mas pela vantagem de deixar de ser "pobre como Job"; portanto, ao entrar em contato como a produção concreta da riqueza conforme a semiescravidão, percebe que terá que decidir ou por ser "cúmplice do poder" ou por "opor-se a ele" de algum modo. O que ela vai escolher é de certa maneira interessante: empregar-se na fazenda e proletarizar-se em termos de solidariedade a seu Ribeiro, Marciano etc. O que espantou a crítica nos anos de 1930: o desfecho do romance rompeu de certo modo com a norma nos anos 30: em Cacau ou Suor, por exemplo, romances daqueles primeiros anos, esse tipo de personagem exerce atração sobre os demais e produz a revolta, numa situação de compartilhamento de ideais ou de despertar para a consciência de classe. Diferente disso, Madalena fica sem apoio e só avulta com a morte.

Paulo Honório torna-se um tipo de sujeito caracterizado, desde então, pela passionalidade: ele não age diretamente sobre Madalena, espera dela um "fazer" relacionado às expectativas que tinha construído, ilusoriamente, a respeito dos "deveres" no pacto "casamento": 
Diríamos, em linguagem corrente, que o primeiro sujeito [1] (...) espera que o segundo sujeito [2] (...) cumpra sua parte no contrato (dever), ou seja, faça com que (...) [o sujeito 1] entre em conjunção (...) com seu objeto de valor (...). O objeto de valor é aquilo que o sujeito mais deseja, incluindo, nesse caso, pelo menos hipoteticamente, o próprio [sujeito 2]. Embora se trate de contrato fictício, dele depende toda a confiança depositada em [o sujeito 2]. Caso este último não cumpra o seu dever, as conseqüências no âmbito [do sujeito 1] virão em cadeia:

1. frustração por não obter o objeto de valor almejado.

2. decepção por [pelo sujeito 2] não ter feito o que se esperava que fizesse.

3. decepção consigo mesmo por ter depositado a confiança em alguém que não a merecia.

4. ofensa sofrida [pelo sujeito 1] pelo fato de [o sujeito 2] ter feito justamente o que não se esperava que fizesse (...) (TATIT, 2001: p. 112) ${ }^{102}$

Hipoteticamente, são estas consequências que podem ocorrer no estado em que se encontram Madalena e Paulo, a partir do ponto de vista formulado pela semiótica. Naturalmente o que se descreve aqui é o aspecto tensivo:

\begin{abstract}
O estado passional descrito até aqui é comum a numerosas situações que culminam com a manifestação de "ódio", de "revolta", de "ciúme", de "vingança" etc. Também é comum os episódios em que a explosão emocional é contida em favor de sentimentos como "amargura", "ressentimento", "resignação" etc. (TATIT, 2001: p. 113)
\end{abstract}

O ciúme advém da frustração. A reação é a busca de uma prova de traição e ninguém mais é alvo do ciúme senão aquele de quem se "idealizou", em resposta, um ser e fazer característicos da reciprocidade.

A cólera é sempre orientada para um indivíduo concreto, que não tem que ser necessariamente o causador do dano: este pode ter sido causado por Madalena, e a cólera recair sobre Marciano, como no caso do material escolar; ou provir de qualquer contrariedade inesperada, e recair a cólera sobre Madalena, como com o dínamo emperrado. Madalena pode estar no centro das perturbações, mas Paulo Honório, colérico, vinga-se em Marciano, ou Padilha, ou seu Ribeiro, ou dona Glória. (BAPTISTA, 2005: p. 116)

Enquanto tomado pela cólera, Paulo agride às cegas. Porque não consegue distinguir o que provoca o desconcerto repentino dos negócios, parte para a agressão como meio de manter o controle e sustentar-se na posição conquistada anteriormente. Liga à "desordem”, ainda nesse momento, a hipótese de que “(...) Madalena possuía um excelente coração” (p. 104). Entretanto não será necessário muito tempo para que, nesse "excelente coração", enxergue "motivos" mais pertinentes a todas as mudanças que ela tenta efetuar em seus negócios e nas relações. Aí começa a desconfiança de traição que desperta a busca de um culpado. E não será estremecendo e agredindo aleatoriamente que vai desafogar-se: a agressão será mais moral,

${ }^{102}$ Greimas formulou a seguinte equação para a passividade: "S1 crer [S2 dever fazer (S1 ก Objeto v.)]". 
como se a ofensa recebida fosse digna de castigo meticuloso: lembremo-nos que ele vem de um mundo em que a ofensa sofrida pede uma resposta que lhe devolva a honra perdida.

No capítulo 24, diz Paulo que estava casado há dois anos, por isso os amigos jantariam com eles (lembremo-nos das multiplicações de capítulos: do 12, primeira reunião, ao 24, segunda, como um processo cumulativo de produção de ilusão que se intensifica). Exatamente nesse dia, diz ele ter repreendido Padilha: encontra-o no jardim, onde colhia flores, e lhe diz: "Ninguém aqui está preso. Se o serviço lhe desagrada, é arribar" (p. 124). Padilha não entende o porquê da repreensão. Paulo, apontando o relógio, lhe dá a entender que àquela hora um trabalhador não estaria "colhendo flores". Padilha the explica que, na verdade, quem lhe havia dado aquela ordem fôra Madalena, para enfeitar o escritório, onde ela agora trabalhava. Isto é, o projeto de Madalena de "morar no campo e ter um jardim” não se anulou com a real condição da fazenda, mesmo tendo ela se proletarizado. E Padilha alude a conversas com Madalena, que vinham desagradando o fazendeiro, mas que não produziam nenhum efeito até então.

Assim, no ato de justificar-se, Padilha vai desencadear no imaginário de Paulo Honório o exato motivo do "desconcerto" a que tem assistido; diz ele ao patrão:

(...) E quanto às conversas, seu Paulo compreende (sic). Uma senhora instruída meter-se nestas bibocas! Precisa de uma pessoa com quem possa entreter de vez em quando palestras amenas e variadas.

Achei graça. E não prestei mais atenção a Padilha, que, espetando os dedos nos espinhos, devastou uma roseira, à pressa, e escapuliu-se. Palestras amenas! (...) (p. 124)

Ora, exatamente o Padilha, o qual Paulo Honório deixou na miséria, vingando-se como se o filho de Salustiano fosse o responsável por ele "gastar enxada por alguns tostões", enquanto ele se formava bacharel, vai tocar em seu mais íntimo e recôndito "medo": embora tenha se tornado um homem medianamente rico e poderoso, o capital não o modificou culturalmente (ele tomou a herdade material, mas não a condição de poder ter com sua esposa "palestras amenas e variadas"; ele é o mesmo Paulo que trabalhou no eito, a cinco tostões por doze horas; o mesmo das "sentinelas"; o mesmo agregado, sem pai nem mãe, criado pela velha Margarida; enquanto Madalena é "superior, escreve artigos no jornal da Capital" e Padilha pode ter com ela "Palestras amenas e variadas").

Com a proposição "palestras amenas e variadas", Padilha exclui Paulo de um mundo, do qual ele não faz parte verdadeiramente, mas em que, pelo poder financeiro, corrompendo pessoas, pôde achar um lugar. 
Esta particularidade do capital, que valoriza o homem, não enquanto homem, mas como mercadoria, está no cerne do drama de Paulo Honório em São Bernardo. E Paulo o sente na pele. Seu valor humano e social inexiste no meio burguês, apenas seu valor como produtor material de riqueza. E mais tarde, no escritório,

(...) uma ideia indeterminada saltou-me na cabeça, esteve por lá um instante quebrando louça e deu o fora. Quando tentei agarrá-la, ia longe. Interrompi a leitura da carta que tinha diante de mim e, sem saber porquê, olhei Madalena desconfiado. (p. 125)

Diz ele que, naquele momento, observou Madalena distraída, mexendo numas folhas e contemplando os paus-d'arco floridos. "Maquinalmente, assinei o papel; Madalena estendeume outro, maquinalmente. Nisto a ideia voltou. Movia-se, porém, com tanta rapidez que não me foi possível distingui-la. Estremeci (...)" As relações entre "palestras amenas", "a ideia que chega quebrando louças e dá o fora" e sua relativa reaparição em "assinei o papel", indicialmente revelam o inconsciente de Paulo Honório. O encontro do que está dentro dele com o que se insinua "aparentemente" na exterioridade se expressa novamente, como no caso do pio da coruja, como "estremecimento". Essa reação espontânea sempre se manifesta a partir da ameaça da morte: durante os tiroteios, nos episódios da guerra entre ele e Mendonça, os tiros o fazem "estremecer".

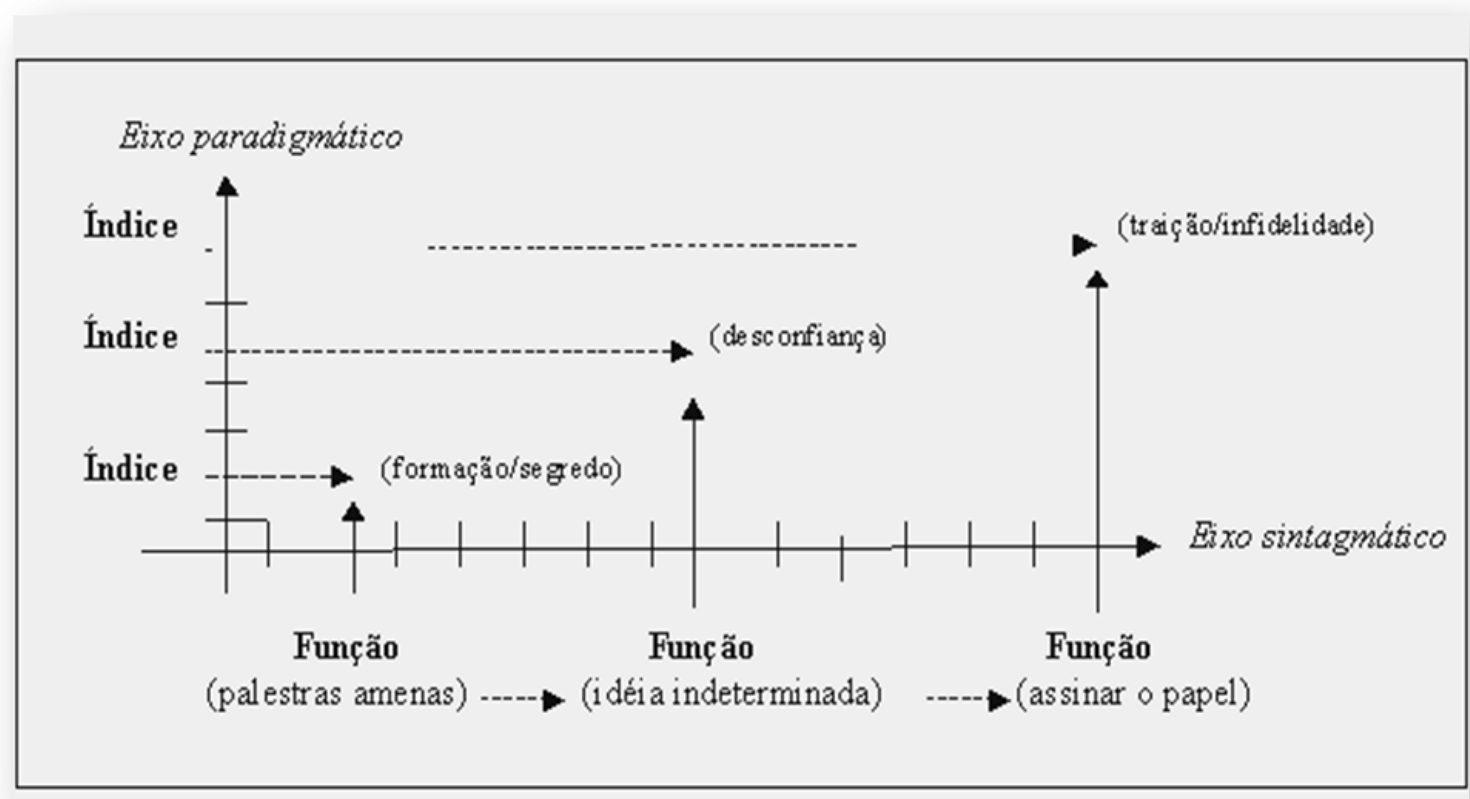

Depois de "estremecer", diz ter parecido a ele que "a cara de Madalena estava mudada. Mas a impressão durou pouco". Sendo a "imagem" de Madalena marcada pela 
"impressão" rápida, instaura-se em seu imaginário um tipo de desconfiança diferente da que vinha tendo; em detrimento da ideia de que Madalena era uma pessoa "exageradamente boa" e que desconhecia a administração de uma fazenda, assume, agora, esta posição, a ideia de que ela mente através de uma escrita que ele não compreende, uma linguagem que o ameaça e cujos segredos estariam se dando entre ela e Padilha. Coisas inacessíveis a ele, por falta de conhecimento/compreensão da linguagem, que no ato de "assinar documentos" estariam sendo sabotadas; tais aspectos inserem em Madalena a inversão da verdade, mentir, por parecer e não-ser.

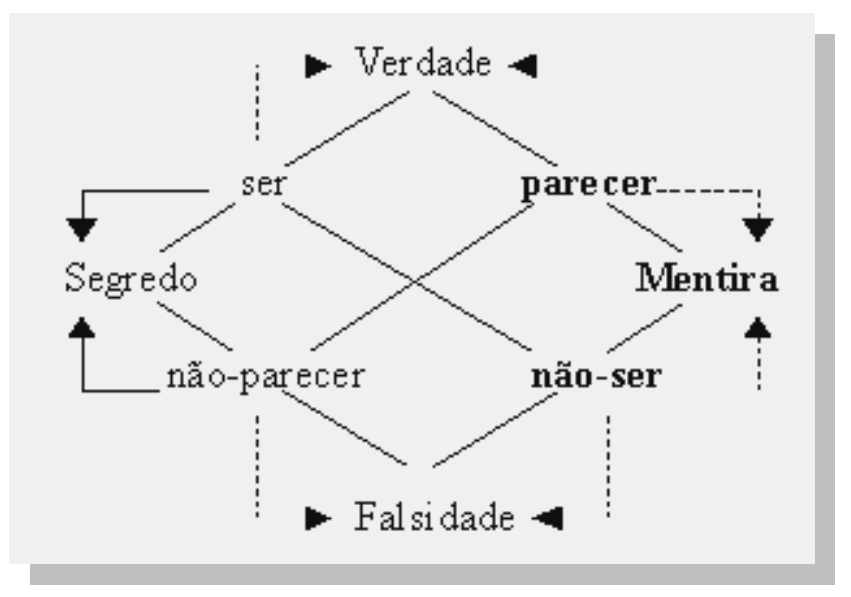

Na imaginação de Paulo, Madalena passa por um processo de reconhecimento (subjetivo): o par do gráfico "ser" e "parecer", garantia de verdade, representavam-se por sua "bondade" que, por consequência, desencadeava-lhe a cólera. Lembremo-nos do "quem dá o que tem vem a pedir".

(...) A cólera permanece ligada à posse material e ao governo da fazenda, enquanto o ciúme, envolvendo obviamente a posse de Madalena, não depende da fazenda, nem do domínio sobre os trabalhadores, nem da interferência de Madalena no governo de S. Bernardo, mas do laço amoroso que conduziu o casamento. O alvo da cólera transita de um para outro, e nesse processo Madalena, ainda que no fulcro das perturbações, é o alvo entre outros; mas no ciúme é insubstituível. (BAPTISTA, 2005: p. 118)

A partir da conversa com Padilha e da cena no escritório, instaura-se na imaginação de Paulo o par "parecer" e "não-ser", índices de mentira, principalmente pelo fato de a ter visto com "outra cara", ou seja, desconfia da primeira imagem: a de que "Madalena tinha um excelente coração" (que passa a ser apenas aparência), o que não provocaria senão divergência no modo de proceder economicamente. Mas a falsidade ou mentira constitui-se "cilada". O que este episódio nos mostra é o momento da transição da impressão que Paulo tem sobre 
Madalena; e ele continua a investigá-la no jantar: quando, entre eles, na conversa sobre política, padre Silvestre assinala "Mas não se iludam. Há de haver uma revolução!" (p. 127) e Madalena, ao perguntar-lhe o porquê, faz com que Paulo diga bruscamente: "Você também é revolucionária? exclamei.”, que representa uma tentativa de compreensão do que ele jamais poderia ter compreensão.

Madalena não percebe a desconfiança por trás da pergunta e trata o assunto de forma natural, dizendo que "Seria magnífico" (p. 128). Paulo continua a ligar às ideias que teve no escritório (relacionadas à escrita), antes do jantar, a cada detalhe que surge nas opiniões de Madalena.

De repente invadiu-me uma espécie de desconfiança. Já havia experimentado um sentimento assim desagradável! Quando? (...) [continua, mais adiante, enquanto os convidados conversam] Quando? Num momento esclareceu-se tudo: tinha sido no escritório, enquanto Madalena me entregava as cartas para assinar.

Sim senhor. Conluiada com o Padilha e tentando afastar os empregados sérios do bom caminho. Sim senhor, comunista! Eu construindo e ela desmanchando. (p. 130)

Enquanto o que havia nas atitudes de Madalena correspondia apenas à generosidade gratuita e irrefletida, mas que podia desencadear a desordem na mentalidade de seus agregados, tudo não passava de malentendido; agora isso the parece planejado. As conversas seguem-se sem que nada lhe escape à investigação: "Materialista. Lembrei-me de ter ouvido Costa Brito falar de materialismo histórico. Que significava materialismo histórico? (...) Comunista, materialista. Bonito casamento! Amizade como Padilha, aquele imbecil. 'Palestras amenas e variadas.' Que haveria nas palestras? Reformas sociais, ou coisa pior. Sei lá. Mulher sem religião é capaz de tudo.” (p. 131)

E finalmente, tomando forma completa, a desconfiança aprofunda-se: "Procurei Madalena e avistei-a derretendo-se e sorrindo para o Nogueira, num vão da janela" (p. 32); instaura-se por completo a transição de "cólera", ligada à posse material ou o domínio/poder, ao "ciúme/traição", afrontando a honra, retirando-lhe a posse subjetiva do controle, assim como a posse objetiva do status, em forma de origem/casta superior. Imagina os castigos por tal afronta moral, nos moldes das vinganças sertanejas, as mais violentas como forma de exemplaridade. Mas falta-lhe a prova. O que mantém Madalena no nível, agora, de ser "materialista, comunista" (ser) e "não-parecer", já que ela continua a agir do mesmo modo com que a caracterizou Paulo Honório como "um bom coração". 


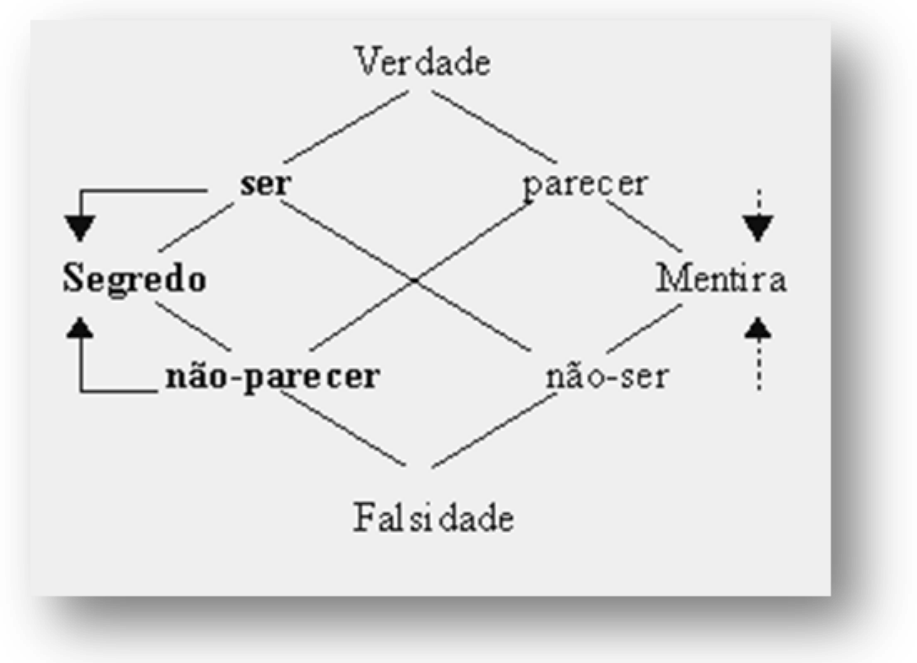

É agora o par "ser" e "não-parecer" que se lhe insinua à mente, ou seja, Madalena guarda um segredo imanente à escrita ou ligado ao "conhecimento" que ele não tem, com o qual está minando pouco a pouco seus negócios e a estrutura de poder tradicional. Todavia, por não haver dados concretos, isto é, por ser apenas "uma desconfiança", não saímos do nível do "segredo". Só no ato de "reconhecimento" ou de "desmascarar" o "outro" se the daria o par "parecer" e "ser" (verdadeiro). De ilusões, desilusões, à verdade, coberta pela aparência de "um bom coração". Nessa trajetória se apresentará um verdadeiro espetáculo de horrores. Tudo pela atração de alguém ou de algo que ele desconhecia. Isto é, pela contingência ocorrida no capítulo 12, que deve ser assim entendida aqui:

Do ponto de vista do self contingente, desejar - ser atraído para alguém ou alguma coisa - apenas poderia significar criar as condições para uma coincidência. (Ou, para afirmar isso de outra maneira: não podemos fazer nossas relações funcionarem; apenas podemos fazer nossos compromissos funcionarem. $)^{103}$

Espantosamente, o que atraiu Paulo Honório, inconscientemente, em Madalena, foi o conhecimento que ele não tinha, a instrução do Padilha, referida por ele desde o momento em que negociava o acerto do preço da propriedade, passando pelo momento em que tentou se instruir em poesia, quando encontra o Nogueira e o Gondim discutindo o assunto e, finalmente, quando nos primeiros dias de casados tenta afinar sua sintaxe à de Madalena. Foi o fato de ela ser educada/instruída o motivo, evidentemente, que o levou a se apaixonar por ela. A trama psicológica engendrada ou a linha isotópica articulada desde o princípio da narração, do passado memorial, que o leva gradualmente do desentendimento (marcado pela cólera) ao

${ }^{103}$ PHILLIPS, Adam - O Flerte / São Paulo: Companhia das Letras, 1998. (Cf. p. 53) 
ciúme (marcado pelo domínio de um saber não compartilhado, isto é, pela traição), está amarrada ou dinamizada pela não reciprocidade de dois caracteres completamente opostos.

Adam Phillips propõe, em seus ensaios sobre a contingência, que ela é sempre resquício da história (passado) de um desejo do qual o indivíduo não mais se lembra. O que parece coincidência, neste caso, seria, na verdade, apenas um daqueles aspectos das buscas pessoais trazidas à tona por um tropeço, aparentemente fortuito, em algo esquecido.

\begin{abstract}
"Só do acaso depende" é, naturalmente, uma frase curiosa. Para Proust não há como organizar, não há técnica que garanta acesso ao passado. O passado é revelado por coincidências que, em si mesmas, são insignificantes: um cheiro, uma melodia, um gosto. E não há como saber de antemão qual ou quando pode ocorrer. (...) o passado que está dentro de nós não está ativa e furtivamente planejando sua própria revelação, não está procurando atenção. Nem mesmo (...) está aguardando ser descoberto, embora esteja ali, em algum lugar, "nalgum objeto material", se tivermos bastante sorte ou azar para toparmos com ele. (PHILLIPS, 1998: p. 46)
\end{abstract}

No caso de Paulo Honório, podemos dizer que ele teve bastante azar em topar com o fato de que não possuía “domínio da linguagem”/romance (simbolizado no capítulo 12) para que pudesse ter "palestras amenas e variadas" com sua esposa; e a falta desse instrumento seria compensada exatamente pela humilhação daquele que a possuía e que considerou o responsável pela sua situação desonrosa, trazendo-o para a mesma condição de humilhado em que ele esteve no eito. Isto é, Padilha, sem querer, começa a desenterrar algo em Paulo Honório, algo de sua história com o qual ele não planejava topar. E o fato de estar assinando papeis escritos por Madalena, associados, por ele, aos desconcertos nos negócios, significa que ele é literalmente semianalfabeto: pois sua assinatura legitima as ideias, na escrita de Madalena, que vinham produzindo a dissolução do mundo à sua volta. É o que vai levá-lo à busca furiosa da decodificação de tudo que ela escreve e fala, tornando a vida de Madalena insuportável:

"No dia seguinte", conta no capítulo 26, "encontrei Madalena escrevendo. Avizinheime nas pontas dos pés e li o endereço de Azevedo Gondim". Pede a ela a carta: "Faz favor de mostrar isso?" Ela não mostra. Briga. Ele a chama de galinha. Ela pica a carta. Evidentemente já estão em um nível de desorganização emocional, ambos, além do que podem suportar. E o fato de Honório não conseguir decodificar o que lê torna-se um espetáculo fabuloso: "Uma tarde em que a velha Margarida subiu a ladeira à vara e a remo para visitar-nos, vigiei-a uma hora, com receio de que a pobre fosse portadora de alguma carta" (p. 151). No capítulo 30, 
chegamos ao mais recôndito, profundo e escurecido aposento do inconsciente de Paulo Honório:
À noite, parecia-me ouvir passos no jardim. Porque (sic) diabo aquele Tubarão não ladrava? O safado do cachorro ia perdendo o faro. (...)
- Quem está aí? É bicho de fôlego ou é marmota? Não responde não?
E lá ia no silêncio um tiro que assustava os moradores, fazia Madalena saltar da cama, gritando.
(...) Um assobio, longe. Algum sinal convencionado.
- É assobio ou não é? Marcou entrevista aqui no quarto, em cima de mim? (...)
Madalena chorava como uma fonte.
(...) Um pesadelo. Era possível que o assobio fosse grito de coruja. (...)

\section{1}

Uma tarde subi à torre da igreja e fui ver Marciano procurar corujas. Algumas haviam se alojado no forro, e à noite era cada pio de rebentar os ouvidos da gente. Eu desejava assistir à extinção daquelas aves amaldiçoadas. (...) (p. 154)

Aqui se amarra o nó psicológico do personagem conduzido desde "os gastos com a instrução do Padilha pelo velho Salustiano", com "economia indecente", "palestras amenas e variadas", passando pela escrita/carta, até o elemento mágico ou folclórico do pio da coruja como prenúncio de desgraça caracterizado como "sabença popular". Os termos "bicho de fôlego" (evocação do sopro divino de Deus nas criaturas vivas) e "marmota" (assombração ou fantasma) revelam o lado obscuro em que se organiza sua mentalidade e seu modo de entender o mundo. É seu último recurso o inexplicável explicar os motivos de toda falência. Finalmente, é nesse sentido que pensamos a ideia de contingência, cujo pressuposto é o de que um evento inesperado, aparentemente furtivo, revela-nos um tipo de funcionamento completamente à parte daquilo que pode ser controlado. Isto é, só podemos fazer nossos compromissos funcionar (superfície) racionalizando-os, não nossos relacionamentos internos na totalidade das nossas relações (fundo). O pio da coruja está no inconsciente de Paulo Honório, é algo de que ele não tem recordação nem sabe explicar senão como inexplicável, o sobrenatural, externo a ele, desencadeado pela participação em algum mal. O enigma da coruja e o da escrita, associados a Madalena, é sua "fala incompreensível", que ele não consegue decodificar e tem significado apenas de "azar" e "morte", tragédia prenunciada.

O drama de Paulo Honório é que ele é um ser constituído num tipo de trajetória cultural desconhecida pela modernização; a reificação é só um fenômeno de superfície, não "subconsciente", assim, não é esse romance apenas um estudo do sentimento de propriedade. Já os fenômenos do subconsciente têm raízes obscuras, de difícil explicação, mas que podem ser remontados a partir da trajetória particular do indivíduo. Neste caso, em termos de 
narrativa, o enigma do pio da coruja se torna algo da ordem do metafísico, prenúncio de castigos medonhos e infernais que não se aplacam simplesmente pela forma como aprendeu resolver os problemas: eliminando a contrariedade pela violência.

Verificamos até aqui, portanto, a correspondência entre "escrita" ou "saber intelectual", nos termos "palestras amenas e variadas", mencionadas pelo Padilha, cuja explicação ideológica ocorre no capítulo 12 , do ponto de vista das convenções de um gênero literário produtor de ilusão. Na trajetória particular do protagonista, a "escrita" está ligada a uma manifestação mais antiga: lembremo-nos de como Paulo Honório se refere a Salustiano Padilha, o pai de Luís, no momento em que decide voltar ao lugar em que trabalhara no eito:

Resolvi estabelecer-me aqui na minha terra, município de Viçosa, Alagoas, e logo planeei adquirir a propriedade S. Bernardo, onde trabalhei no eito, com salário de cinco tostões.

Meu antigo patrão, Salustiano Padilha, que tinha levado uma vida de economias indecentes para fazer o filho doutor, acabara morrendo do estômago e de fome sem ver na família o título que ambicionava. (pp 15 e 16)

É essa a sua relação mais antiga com o "conhecimento/saber". Lembremo-nos do caráter vingativo dele em relação aos que o maltrataram, como o Pereira. Não é esta, pois, a raiz profunda da origem da sua volta a Viçosa? Vingar-se do Padilha? Tomar-lhe as terras? Casar-se com uma letrada? Humilhá-lo com o mesmo elemento de sua humilhação, tirandolhe a herança. Mas há algo que ele não pôde herdar: a capacitação que lhe daria o direito exclusivo de ter com sua esposa "palestras amenas e variadas". Ironicamente, é com o Padilha que, em função de sua educação, ela pode comunicar-se, não com ele, deixando-o na mesma posição em que esteve no eito e tirando de Paulo Honório o que ele mais ambicionava. É para recuperá-la, no início do romance, que ele se lança ao projeto da escrita do livro. Isto é, recuperar-se a si mesmo, reconquistar a honra perdida: contando sua história e a de Madalena se apaziguaria, já que ela, de fato, não o traiu, não o reduziu à condição do Jaqueira. Com a renovação do "pio da coruja", ele abandona o projeto de honra e passa a perseguir o motivo do erro, o que o faz um personagem trágico, literalmente.

A volta do pio da coruja no momento em que o projeto de escrita do livro faliu completamente renova as expectativas de morte. A coruja que pia marca a fronteira entre Paulo Honório, no mundo da matéria, e Madalena, no mundo dos mortos (na sua mentalidade). Além de fazer a mediação, enquanto linguagem entre os dois mundos, desses dois planos. Ultrapassar essa linguagem seria, para ele, atravessar o desconhecido em busca da compreensão dos erros. Ele não tem a menor intenção de redimir a honra de Madalena, 
confessando sua culpa. Ele simplesmente não consegue localizar a culpa dela exatamente por ela representar uma linguagem à qual ele não tem acesso: o romance.

Evidentemente, tudo isso se passa em sua mente. Não estamos fazendo aqui análise psicanalítica ou exame metafísico do romance, mas sim a análise de um elemento que remete a ele, localizado no universo psicológico do personagem. É apenas um ponto passivo de análise crítica. Nada em São Bernardo poderia ser submetido a este tipo de análise: é o romance fazendo a crítica desse aspecto literário: a ignorância do narrador o leva a substituir os motivos orgânicos do conflito por motivos metafísicos. Lembremo-nos de que também essa perspectiva teve bastante espaço e influência na literatura dos anos de 1930. Sobretudo a partir de escritores que se identificaram com a Igreja Católica e seus projetos político-sociais, segundo a concepção, grosso modo, de que os problemas sociais tinham origem na alma ou poderiam ser solucionados pela condição espiritual dos homens em sociedade. Por isso São Bernardo não é apenas metaliterário no sentido de auto referir-se à sua possibilidade de construção. Ele é, também, crítica de possibilidades de construção literária e de suas próprias leituras possíveis. 


\section{Declínio: nascimento e morte}

Aquilo era meio de vida, não era meio de morte. (p. 166)

No final do capítulo 24, em que nos são contadas as peripécias do jantar em comemoração do 2..$^{\circ}$ ano de casamento de Paulo, dá-se o início aos episódios em que a desconfiança do protagonista leva-o às mais extremadas atitudes. Em princípio, vê no Padilha indícios de que ele estaria invertendo a situação, como aconteceu ao Jaqueira; depois vê no amigo, o advogado João Nogueira, afinidades intelectuais com Madalena. O protagonista desconfia de que, antes de se casar, Madalena e Nogueira poderiam ter namorado: "Confio em mim. Mas exagerei os olhos bonitos do Nogueira, a roupa bem feita, a voz insinuante" (p. 132). Paulo analisa a si mesmo como homem não requintado, refinado pela cultura como o advogado, que inclusive o levou a exacerbar a beleza física do outro a ponto de deformar a si mesmo. Lafetá chega a apresentar o protagonista de São Bernardo como “(...) este aleijão [reificado] que ele descreve e vemos por toda parte: o coração miúdo e uma boca enorme, dedos enormes.(...) A vida agreste, que o fez agreste, é a culpada por Paulo Honório não enxergar Madalena" (LAFETÁ, 2004: p. 91).

Desde a última etapa de análise, vínhamos considerando alguns aspectos semióticos ligados à tensividade; aspectos estes decorrentes das desconfianças em que se submerge o protagonista e que aparecem no texto explicitamente: "confio em mim" ou "invadiu-me uma espécie de desconfiança”. Se pusermos no quadrado semiótico este dado explícito, teremos os seguintes termos:

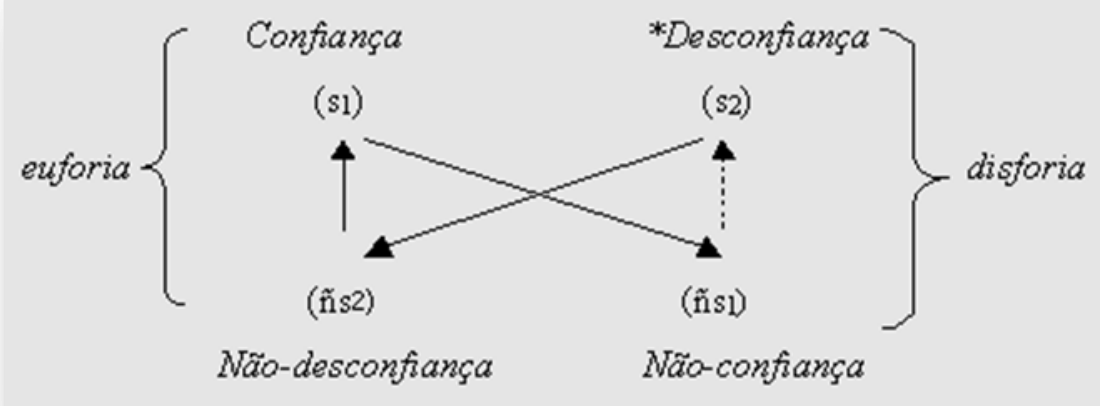

Nesse esquema, os topoi [s1] e [s2] serão sempre ocupados por valores que, como tais, possuem direções apontando, em última instância, ao termo contrário. Tais direções já são dotadas de descontinuidade (a negação: [ñs1] nega [s1]), continuidade (a afirmação do termo complementar [s2] é, 
sobretudo, de uma força que faz de cada valor um "ir para", mesmo que num texto concreto o termo contrário não se manifeste. (TATIT, 2001: p. 23)

Bem entendida, a continuidade é exatamente a permanência de um estado ou evento qualquer em que transita o sujeito, a partir de rupturas, para outras "continuidades" 104 . Nos termos de nossa análise, importa-nos saber que, na transição de um estado a outro, num texto concreto, indicam-se as passagens dos estados de continuidade e descontinuidade, presentes na enunciação e inscritos no enunciado. Antes de encontrarmos Paulo no estado atual, ele ocupava a posição de "confiança", estado de euforia, conforme o bom andamento da "fazenda/poder/honra". Porém, ao principiar o desconcerto de seus negócios, verificamos um estado de transição caracterizado pela disforia. Em estados disfóricos, naturalmente o sujeito procurará encontrar ou readquirir o estado de bem-estar perdido, recuperando o objeto do qual fora afastado: na enunciação, sabemos que o objeto é o livro; no enunciado, Madalena e "fazenda/domínio simbólico". E, nessa tentativa de reaver a "confiança" em Madalena, segundo sua traição ou não, desfere sobre ela verdadeiras brutalidades.

Esse é, portanto, um dos traços da continuidade de um estado que não pode perpetuarse, algo deve acontecer ou deve ser feito pelo sujeito a fim de reconquistar a "paz", o que Paulo consegue parceladamente, ao despejar sua cólera sobre "outrem". Mas, no ciúme, só pode reaver a confiança em Madalena mediante "prova".

Agüentar! Ora agüentar! Eu ia lá continuar a agüentar semelhante desgraça? O que faltava era uma prova: entrar no quarto de supetão e vê-la na cama com outro.

Atormentava-me a ideia de surpreendê-la. Comecei a mexer-lhe nas malas, nos livros, e a abrir-lhe a correspondência. Madalena chorou, gritou, teve um ataque de nervos. (p. 137)

Perceba-se que o mediador que o levaria à verdade vai ser sempre a escrita. Desvendá-la possibilitaria a ele descobrir as provas do segredo. Contudo, apesar das investidas de Paulo, que admite ter tornado a vida conjugal insuportável, não conseguiu nenhuma. A seguir, "o pio da coruja" confundiu-se, na mente do fazendeiro, com assobios que ele julgava ser dum suposto amante da esposa. Bem, já sabíamos que "o pio da coruja" era figura simbólica de "morte anunciada"; e o protagonista tinha conhecimento desse dado no passado.

\footnotetext{
${ }^{104}$ Atualmente, essas noções vêm sofrendo algumas alterações: tensão e relaxamento seriam os termos mais apropriados quanto à condição humana, mais próximos da realidade portanto. Contudo, manter-se-ão, mesmo assim, aqui os termos contínuo e descontínuo.
} 
Sobe com Marciano na torre da igreja: "Eu desejava assistir à extinção daquelas aves amaldiçoadas" (p. 154)

Daquela perspectiva, "em cima" da torre da igreja, o protagonista passa a observar toda a sua obra, sente-se em paz com Deus após Marciano exterminar as corujas que lá se haviam aninhado: "Desci, pois, as escadas em paz com Deus e com os homens, e esperava que aqueles pios infames me deixassem tranqüilo". O jogo engendrado no capítulo 31 entre o "pio da coruja" (prenúncio de morte no folclore brasileiro) e o lugar "acima da igreja" instaura uma espécie de luta contra a morte (que se associa ao ciúme, suspeita de traição/desonra, traço humano). Para que o protagonista supere a morte simbolizada nas aves, manda matá-las. Afinal sente-se novamente seguro, acima da morte e dono do controle na superfície, onde Madalena foi vista por ele no escritório escrevendo "linhas invisíveis".

Lembremo-nos da descrição panorâmica da fazenda no dia do casamento: ironicamente esta é a última vista que Paulo terá de sua obra; irônica, sobretudo, porque a ilusão de subir ao topo da igreja e decretar a morte da "morte", força da qual está à mercê, darlhe-ia novamente o controle. Mas, ao descer da torre da igreja, encontra uma carta trazida pelo vento e deduz pela caligrafia ser da esposa. Ora, na superfície, o descontrole o arrebata novamente. Acredita ter encontrado a "prova" da traição: "Está aqui a prova, balbuciei assombrado" (p. 157). A carta destinava-se a ele mesmo, parte de um esboço em que Madalena lhe anunciava o suicídio. E o fato de referir-se ao destinatário no masculino, sendo o único elemento que ele decodifica acertadamente, revela mais uma vez sua incapacidade de penetrar no discurso.

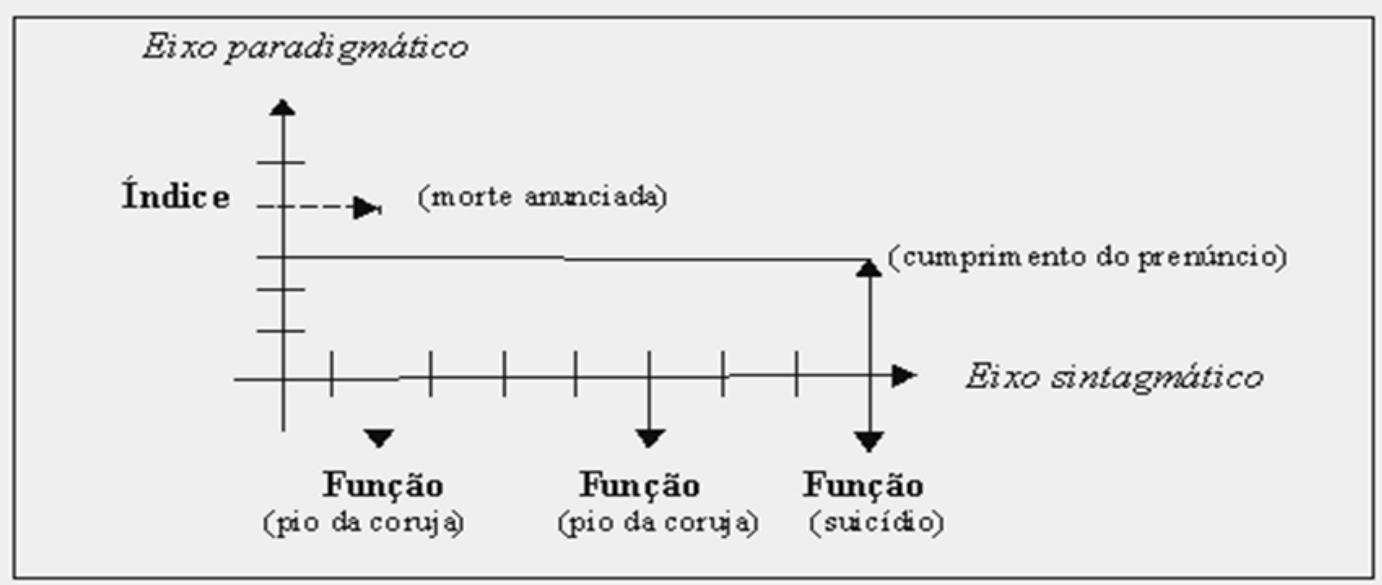


Assim, o que Paulo julgava ser a verdade sofre falência clara, estabelecendo-se definitivamente a verdade de Madalena, contudo, quando ela já está morta: "Muitas vezes por falta de um grito se perde uma boiada". (p. 161)

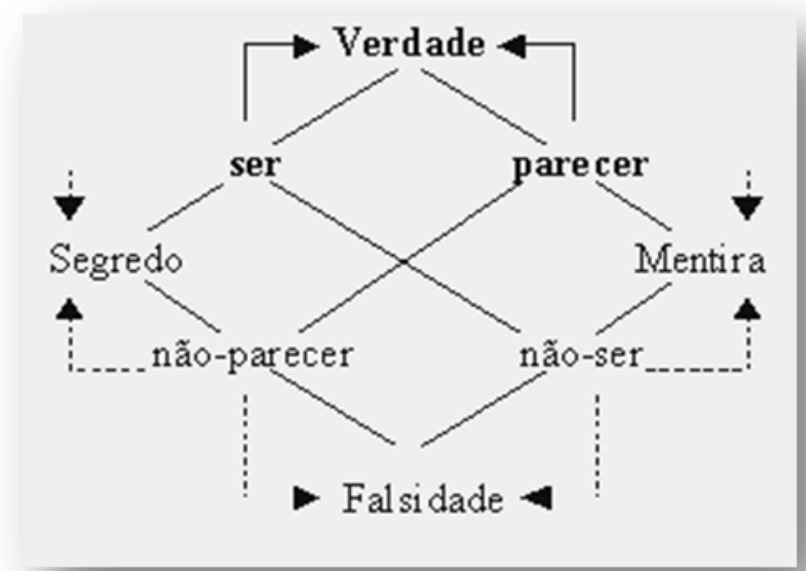

Contudo, o protagonista não reencontra "a confiança" perdida. Paulo atribuía a tal sentimento as supostas traições de sua esposa, o que se esclarece completamente. O que ocorre, portanto, é a transferência da "desconfiança" em Madalena para si mesmo, ou seja, o problema estava nele mesmo. Com isto, mantém-se o estado disfórico e a busca será a do desvendamento do erro. Qual seria o motivo do azar, da má sorte e de estar ele ainda sob o prenúncio de desgraça?

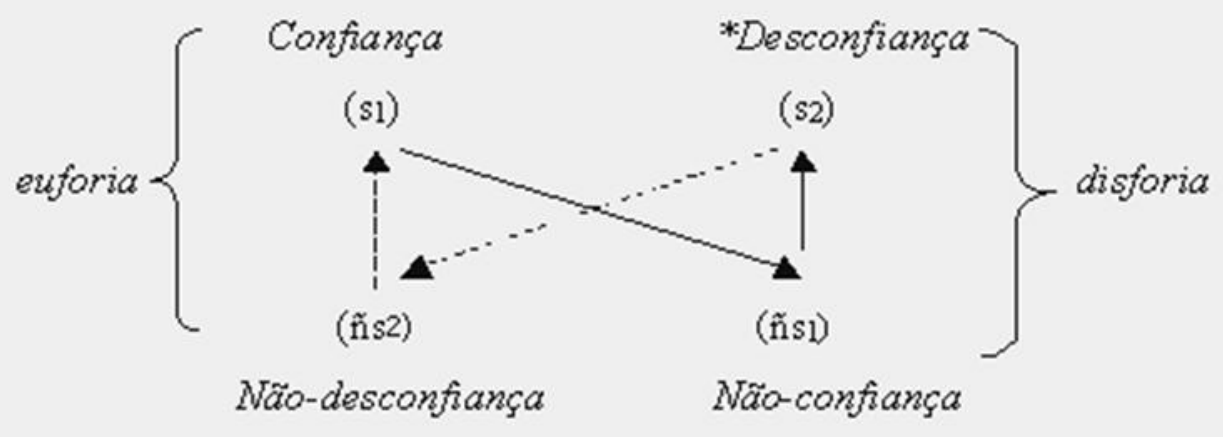

Fato, contudo, foi Madalena ter engravidado e dado à luz um menino, sem detalhes do parto e sem nomear a criança. A força desse detalhe é de suma importância para a compreensão de São Bernardo: o herdeiro era parte do objetivo do protagonista. Porém, sem a 
mãe, ele deixa de representar os desígnios ou desejos reais de Paulo, ou seja, ele adquire o objeto de valor perseguido, mas não a "confiança" em seus atos. Logo, como encaminhá-lo? Como, ele mesmo referiu no capítulo 2, “(...) e lhe ensinar as regras de bem viver” (p. 11), se a ilusão produzida pela "desilusão" desfez aquele juízo naturalista de que “(...) Se o casal for bom, os filhos saem bons; se for ruim, os filhos não prestam. A vontade dos pais nem tira nem põe. Conheço o meu manual de zootecnia"? (p. 87) Até então tal regra servia para ele. Com a falência do negócio, ele próprio cai nas contradições produzidas pelas leis da zootecnia: estaria ele nessa relação como o poder? Isto é, seria ele filho legítimo?

O drama de Madalena é tão complexo quanto o de Paulo Honório. O fato de ser duplamente determinada é uma das mais claras consequências disso:

Ter um emprego significa participar da vida comum, ser capaz de construí-la, sair da natureza para fazer a cultura, sentir-se menos insegura na vida. Uma atividade ocupacional constitui, portanto, uma fonte de equilíbrio. Todavia, o equilíbrio da mulher não pode ser pensado exclusivamente como o resultado do exercício de uma atividade ocupacional. Seu papel na família é a contrapartida necessária de suas funções profissionais, nas sociedades capitalistas. Sua força de trabalho ora se põe no mercado como mercadoria a ser trocada, ora se põe no lar enquanto mero valor de uso que, no entanto, guarda uma conexão com a determinação enquanto mercadoria da força de trabalho do chefe de família. (SAFFIOTI, 1979: p. 58)

Seu drama é que, como a reificação não é uma doença que atinge uns mais desprevenidos, enquanto outros a anulam por ter "bons sentimentos", ela é um fenômeno superficial que não anula, na consciência humana, nenhuma das realizações cujo valor mercantil poderia servir de esteio. O que Saffioti refere é, portanto, como esse fenômeno atinge a todos no circuito das relações sociais. O que aparentemente tem mero valor de uso, isto é, não produz "mais valia" ou lucro, esconde no fundo possibilidades cuja exploração revela conexões curiosas. A força de trabalho de uma dona de casa, por exemplo, conecta-se à do marido, na medida em que "a força dele", posta no mercado de trabalho, só é possível pela manutenção da força da mulher.

E isto é simples. À medida que Madalena emprega-se na fazenda, ela está realizando um trabalho dobrado enquanto ente social que se realiza em certo âmbito existencial da sociedade: isso não anula as realizações consideradas domésticas, que ela caracterizou como "lugar para dormir", ainda que as funções do lar ou de mãe sejam desempenhadas por outros. Madalena mede o valor do lar, local da manutenção da força de produção, segundo o "valor de mercado". Por isso o abandono total de tudo que dependia dela nesse âmbito da existência. Sobretudo, a força com que ela põe a venda no escritório da fazenda. 
No capítulo 15, quando vemos juntos Paulo e Madalena, ocorre o contrário do que pensa a crítica de modo geral: o personagem principal lança mão da sedução, através da ideia do "conforto financeiro", para atrair a simpatia de dona Glória: "Por que sua sobrinha não procura marido?". E dona Glória responde que Madalena "não é feijão bichado para andar se oferecendo" (p. 87). Já conhecemos a passagem em que Madalena diz "ser vantajoso" o "oferecimento" do fazendeiro; e, mais tarde, que "não sente amor"; contudo, no capítulo 16, em que Paulo vai à casa de Madalena, narra-se a "inconveniência" do Gondim, que dá felicitações pelo casamento antes da hora (p. 90). Para disfarçar, Paulo fala do Grêmio Literário e Recreativo, orientando o rumo da conversa a livros. Evidentemente, o personagem desqualifica a literatura, a "instrução", com o que não concordam. Como ela não percebeu que seria sobremaneira necessário a ele compreender o valor do conhecimento? A liberdade de Madalena dependia da libertação de Paulo Honório. Eles estavam conectados, ainda que não amorosamente, numa relação em que o aprimoramento dele dependia da capacidade (dos saberes) dela, como "manutenção da força de produção dele", em termos qualitativos.

Madalena, como co-produtora da mais-valia extraída por ele, não entendia que da sua força de trabalho (instrução) dependia a de Paulo Honório, porque tal força (sua educação ou saberes) não estava a serviço de sua realização pessoal, exclusivamente, fora da família, mas apenas de sua realização como "ser social". Isto é, ela é pura ideologia: seus investimentos de "vestir”, "dar conforto”, por exemplo, à velha Margarida, não representam uma transformação, de fato, na condição social e humana da velha negra, apenas têm como função dar uma aparência de transformação: ela própria ignorava que, na concepção da velha, sua atitude era "despótica".

Isto é, ela ignorava, cega pela ilusão idealista, que a verdadeira transformação só poderia ter efeito pela modificação do modo de ver da velha negra, de Paulo Honório, do direito de participação nas riquezas, nas conquistas humanas, sociais e econômicas, para as quais contribuíam com sua força de produção. Ao empregar-se na fazenda, Madalena assina um contrato definitivo de compra e venda com o marido, produzindo um elo disfórico entre ela e o "ambiente privado": sua realização não mais será a de um ser duplamente determinado, social e humano.

Quando a crítica eleva Madalena a heroína do romance, apenas valoriza a ideia de que a mulher se liberta ao exercer uma profissão, um ideal, desconsiderando o fato de que "Se a mulher é duplamente determinada [biológica e socialmente], a consciência do homem é 
duplamente contraditória” (SAFFIOTI, 1979: p. 44). Ou seja, não é possível a mulher libertarse sem que isso ocorra também com o homem: a consciência de que sua força produtiva, no ambiente doméstico, tem valor de uso apenas se for reduzida sua participação na força de trabalho masculina assim como anulada a condição humana, biologicamente, pondo-os em condições desiguais. Antecipemo-nos: nossa análise aqui se orienta para a literatura. E a aplicação da distinção entre realização do ente-social, no âmbito da cultura, realização do ente-privado, no ambiente doméstico, mediado pelo valor de troca, implica um tipo de leitura possível do romance sobre si mesmo.

Lembremo-nos de que Madalena emprega-se no escritório da fazenda dois dias depois do casamento. Não tem nada a ver com o ciúme, desencadeado depois. Emprega-se simplesmente porque não foi para o campo para, deitada numa rede, dar ordens na cozinha, isto é, participar dos serviços considerados domésticos. Por isso, há um rompimento entre Madalena e o filho. Tal disforia inicia-se no capítulo 24, após Paulo irritar-se com d. Glória que, com as leituras de romances, acreditava ele atrapalhar o serviço de seu Ribeiro. Madalena pede -lhe que explique o porquê de não gostar de sua tia:

\footnotetext{
- $\quad$ Eu? Nem gosto nem desgosto. Pensei que ela quisesse ocupação. A propósito, é bom você deixar a máquina. Aquilo é ruim para a barriga. Não se sente mal?

- Não.

- $\quad$ Em todo caso uns meses antes e uns meses depois do parto tem férias.

- Obrigada.
}

Diz Heleieth Safiotti que "É preciso lembrar, a necessidade de trabalhar não deriva tão-somente da vontade de sobrevier fisicamente" ( p. 39). A sobrevivência do ser social que é Madalena impõe, nesse caso, que ela trabalhe a fim de que se realize na cultura. Contudo, isso não anula o fato de que ela é mulher, numa dupla determinação: de um lado, um ser social; de outro, um ser humano do sexo feminino. Estar grávida é índice do ser, também, humano que ela é. E, ao ter ignorado este lado da moeda, participou da coisificação da vida humana tanto quanto Paulo.

Em termos de enunciação, o protagonista reconhece sua falha ao rememorar os fatos, mas a partir da concepção de Madalena: a personagem funcionaria como perspectiva de leitura da trajetória de Paulo Honório. Ele, por sua vez, por não haver mais forma de livrar-se do peso da "desconfiança em si mesmo", necessitaria dessa perspectiva. Consequentemente o que lhe falta é o que, justamente, Madalena possuía: a comunicação ou o que havia nela que ele não entende, mantendo-o num estado de adivinhação do sentido em vez de compreensão. 
Em parte a culpa era minha: não me tratava. Ocupado com o diabo da lavoura, ficava três dias, quatro dias sem raspar a cara. E quando voltava do serviço, trazia lama até nos olhos: dêem por visto um porco. Metia-me em água quente, mas não havia esfregação que tirasse aquilo tudo. Que mãos enormes! As palmas eram enormes, gretadas, calosas, duras como casco de cavalo. E os dedos eram também enormes, curtos e grossos. Acariciar uma fêmea com semelhantes mãos! (p. 138)

Eis a ilusão produzida pela desilusão. Consta-se por aí que Paulo pensou-se "homem" comparando-se aos outros homens no plano físico, não intelectual. É evidente que ela não nega literalmente a ele oportunidade de aprender. Isso se dá de modo silencioso. Colocando sua força produtiva no circuito do valor de mercado, para equivaler seu valor produtivo no mundo da produção capitalista, ela abandona completamente não só o que sua força de produção era capaz de realizar na esfera das realizações pessoais como também abandona o valor feminino, o valor da mulher, por si próprio regulado, não pelo mercado. A questão não é pessoal, individual: ele não se tratava em outro sentido, não lia livros etc. Daí o ciúme violento que surge quanto aos homens com quem Madalena tem "palestras amenas e variadas". Observemos, por exemplo, o trecho em que Madalena o acusa de assassino:

\footnotetext{
De repente achei que Madalena estava sendo ingrata com o pobre do Casimiro Lopes. Afinal... (...) Casimiro Lopes levava o filho dela para o alpendre e embalava-o, cantando, aboiando. Que trapalhada! Que confusão! Ela não tinha chamado assassino a Casimiro Lopes, mas a mim. Naquele momento, porém, não vi nas minhas ideias nenhuma incoerência. E não me espantaria se me afirmassem que eu e Casimiro Lopes éramos uma pessoa só. (p. 143)
}

Já havíamos chamado a atenção para o fato de que as personalidades de Casimiro Lopes e de Paulo embaralham-se desde o princípio das ações em São Bernardo. Tal aspecto tem como consequência o fato de que ele só pode penetrar nas relações interpessoais do mundo de Casimiro Lopes. O mundo de Madalena se fecha à sua compreensão, exigindo um esforço de decodificação acima de suas capacidades: "Passeando entre as laranjeiras, esqueci a poda, reli o papel e agadanhei ideias indefinidas que se baralharam, mas que me trouxeram um arrepio. Diabo! Aquilo era trecho de carta, e de carta a homem." (p. 157) Ainda aí: "Li a folha pela terceira vez, atordoado, detendo-me nas expressões claras e procurando adivinhar as significações dos termos obscuros". Madalena resistiu completamente a Paulo Honório identificando nele a violência, a brutalidade de um mundo que não só se apresentava em sua figura como estava por toda parte. Seus ideais não levavam em consideração o conhecimento material das condições que sustentavam aquele mundo. 
A repugnância de Madalena por ter percebido que, ao invés de se ter casado por amor, havia se tornado cúmplice de um assassino a levou a recusá-lo por todos os meios. Por isso, também, não nos surpreende a ideia de que o agregado de Paulo faça as vezes de pai e de mãe do menino, "aboiando-o", que seja o único a compreendê-lo, transmitindo-lhe oralmente a tradição, as estruturas de um mundo preexistente a ele e que subsistirá por força da incompreensão:

Casimiro era a única pessoa que the tinha amizade. Levava-o para o alpendre e lá se punha a papaguear com ele, dizendo histórias de onças, cantando para o embalar as cantigas do sertão. O menino trepavalhe às pernas, puxava-lhe a barba, e ele cantava:

\section{Eu nasci de sete meses, \\ Fui cariado sem mamar \\ Bebi leite de cem vacas \\ Na porteira do curral. (p. 136)}

Sendo um dos quadros mais belos de São Bernardo, o interesse de Casimiro Lopes pelo pequeno é a síntese de uma cultura contrária à de Madalena. Casimiro Lopes representa uma instância da permanência do mundo de São Bernardo e que vai perpetuar-se com o nascimento desse novo ser. Casimiro Lopes é um "narrador", transmissor impessoal, tal qual o de que nos fala Walter Benjamin:

\footnotetext{
A narrativa, que durante tanto tempo floresceu num meio de artesão - no campo, no mar e na cidade -, é ela própria, num certo sentido, uma forma artesanal de comunicação. (...) Assim se imprime na narrativa a marca do narrador, como a mão do oleiro na argila do vaso. (BENJAMIN, 1994: p. 205)
}

Ora, o que vai se imprimir, como na metáfora das mãos do oleiro, na existência do filho de Paulo é o mesmo tipo de caráter que tanto Casimiro como ele desenvolveram: sem pai, sem mãe, tocado como animal pela vida (aboiado). A ausência da mãe (Fui criado sem mamar) é a continuidade de certo "mundo": atesta-nos tal hipótese o fato de mais nada ser mencionado sobre o filho de Paulo, senão essa atuação de Casimiro Lopes. Assim sendo, ele representa a ideia de "tradição", cujo movimento é simbolicamente cíclico, também sinalizado pela ideia de retorno ao início do romance, em relações temporais e na descrição da canção de Casimiro, perpetuando-se: "nasci de sete meses", indicando uma má gestação; “criado sem mamar" simboliza, numa construção mise-en-abîme, a ausência da mãe; e "bebi leite de cem vacas”, finalmente, a animalização característica da obra de Graciliano, relembrando o estágio biológico do ser, antes de tornar-se "ser-social". Neste sentido, a criança 
(...) é um novo ser humano e é um ser humano em formação. (...) corresponde a um duplo relacionamento, o relacionamento com o mundo, de um lado, e com a vida, de outro. (...) a criança é um ser humano em processo de formação, do mesmo modo que um gatinho é um gato em processo de formação. Mas a criança só é nova em relação a um mundo que existia antes dela, que continuará após a sua morte e no qual transcorrerá sua vida. ${ }^{105}$

Quando Paulo, no fim do capítulo 2, diz que "o pequeno que ali está chorando necessita que o encaminhe e lhe ensine as regras de bem viver", ao manifestar esta preocupação antes de contar a história de sua vida, indica-nos algo de extraordinário, mas que também passou longe das análises de São Bernardo. Podemos considerá-lo o "liame", sem dúvida alguma, "humano" do drama pessoal do protagonista. Percebe ele que o mundo e a vida humana são coisas distintas. No mundo há "forças" agindo de modo invisível e à mercê da organização que ele conhecia (caso do pio da coruja). Afinal, diz ele que "aquilo era meio de vida, não era meio de morte”, tendo a certeza de que não é alvo de mau agouro à toa.

Portanto, não pode ser meio de vida para seu filho, o que ocasionaria o desaparecimento completo do protagonista e sua memória. Quando diz que a causa de todas as desgraças que viveu foi "a profissão" e, mais adiante, "esta vida agreste”, não está justificando uma falha, apenas quer separar as duas coisas: "a constituição de seu caráter agreste, donde vem sua luta pela vida, desde seu nascimento" e a "instrumentalização do mundo pelo trabalho", especificada no primeiro parágrafo do romance como "divisão do trabalho", vida em sociedade. A mistura dessas coisas parece a ele conter o elo de toda tragédia em sua vida, o que busca compreender pela "composição do livro".

Assim sendo, Madalena, aqui analisada por nós como teatralização dos princípios ideológicos do romance - dado que aparece segundo explicitação de sua consciência a partir de elementos dessa convenção literária -, pode ser vista como uma face nula quanto à capacidade de transformação de uma realidade já estabelecida; sobretudo porque, a partir desta perspectiva, ela é incapaz de transpor o véu das aparências e de resolver questões senão individualmente. Se, por um lado, Madalena se realiza no âmbito de exercer um ideal, numa cultura, por outro lado ela é incapaz de ver-se, a partir daí, em sua condição feminina/humana, adequada a um padrão de valor que não esteja estabelecido pelo valor de mercado. Assim, Casimiro Lopes, simbolicamente, como narrador de histórias de onça, cantigas do sertão etc., transmitirá a permanência de um mundo que ela julgava estar apenas no "coração de Paulo

${ }^{105}$ ARENDT, Hannah. Entre o Passado e Futuro, São Paulo: Perspectiva, 1972. (Cf. p. 235) 
Honório" ou nas suas atitudes, e não que ele fosse a extensão de uma história da qual ela dependia para transformar sua própria história.

Enquanto efeito sobre o leitor, ela satisfaz pelo critério de sensibilidade. Produz afeição, mas não permite, a partir disso, que o leitor penetre nas relações interindividuais e vislumbre as questões afastadas da dependência do afeto. Isto é, não seriam "os bons sentimento de Paulo Honório" que iriam resolver os problemas todos ligados ao mundo a que ele pertence, tampouco os dela. De modo geral, não seria a falta de sensibilidade de um proprietário particular a causa dos problemas históricos, como vimos, envolvidos em São Bernardo.

Todos os problemas enfrentados por Paulo tinham, evidentemente, precedentes históricos: outro recorte adotado por Graciliano representa o período de agitações socioeconômicas e políticas que acarretou grandes transformações na República. A crise econômica mundial de 29 é um dos maiores precedentes dos problemas enfrentados em São Bernardo, que, com a morte de Madalena, culminam na Revolução de 30:

À noite o chefe político escreveu-me pedindo armas e cabroeira. De madrugada enviei-lhe um caminhão com rifles e homens.

Depois os boatos engrossaram e vieram os fatos: batalhões aderindo, regimentos aderindo, colunas organizando-se e deslocando-se rapidamente, bandeiras encarnadas por toda parte, o governo da República encurralado no Rio. (p. 173)

O continuísmo, apesar de Madalena, é inevitável. Não havendo mais o Pereira, outro chefe político o substitui, assim como Paulo Honório substituiu o Mendonça. Em seguida, é a queda política: "Lamentava, sem dúvida, que o meu partido tivesse ido abaixo com um sopro. (p. 174)"; e, finalmente, sozinho, “O resultado foi desaparecerem a avicultura, horticultura e a pomicultura. (p. 178)" É esta a força, aludida por Abel Barros Baptista que

(...) desponta, atua, progride indiferente à profissão, à condição social, à propriedade ou sentimento de propriedade (...) arrastando-o para um drama que seria trágico, se a tragédia tolerasse um herói vilão. (BAPTISTA, 2005: p. 127)

Evidentemente Paulo Honório atribui à crise econômica uma força sobrenatural, sem explicação senão a prenunciada pelo pio da coruja, que lhe vai minando o poder e o reduzindo a sujeito passivo da situação. Com a perda do poder, "o Fidélis e os Gama iam remexer as questões dos limites (p. 179)"'. A queda de Paulo o faz rever a ideia de acumulação. Percebe que voltou à estaca zero e, neste ponto, com um ônus irressarcível: seus cinquenta anos de luta 
e a incompreensão de Madalena. Todavia, não "Madalena em si”, mas sim algo em Madalena que the ficou intangível, herdando ele, no fim das contas, "a não confiança em si mesmo", a não confiança em tudo no mundo; cuja única solução seria compreender Madalena. A volta ao princípio de tudo significa a volta à sua condição humana nua e crua.

Madalena, ainda que morta, não se constitui em uma libertação para ele. Pelo contrário, sua morte uniu-os ainda mais, condenando-o à busca perpétua do significado que ela levou. Ou seja, só Madalena seria capaz de revelar a Paulo Honório quem era Paulo Honório do ponto de vista dela. Daí o novo fito na vida: escrever um livro. Madalena é o enigma, renovado, da escrita. A utopia dele. Busca pelo outro lado do sentido, cuja fronteira está estabelecida pelo pio renovado da coruja.

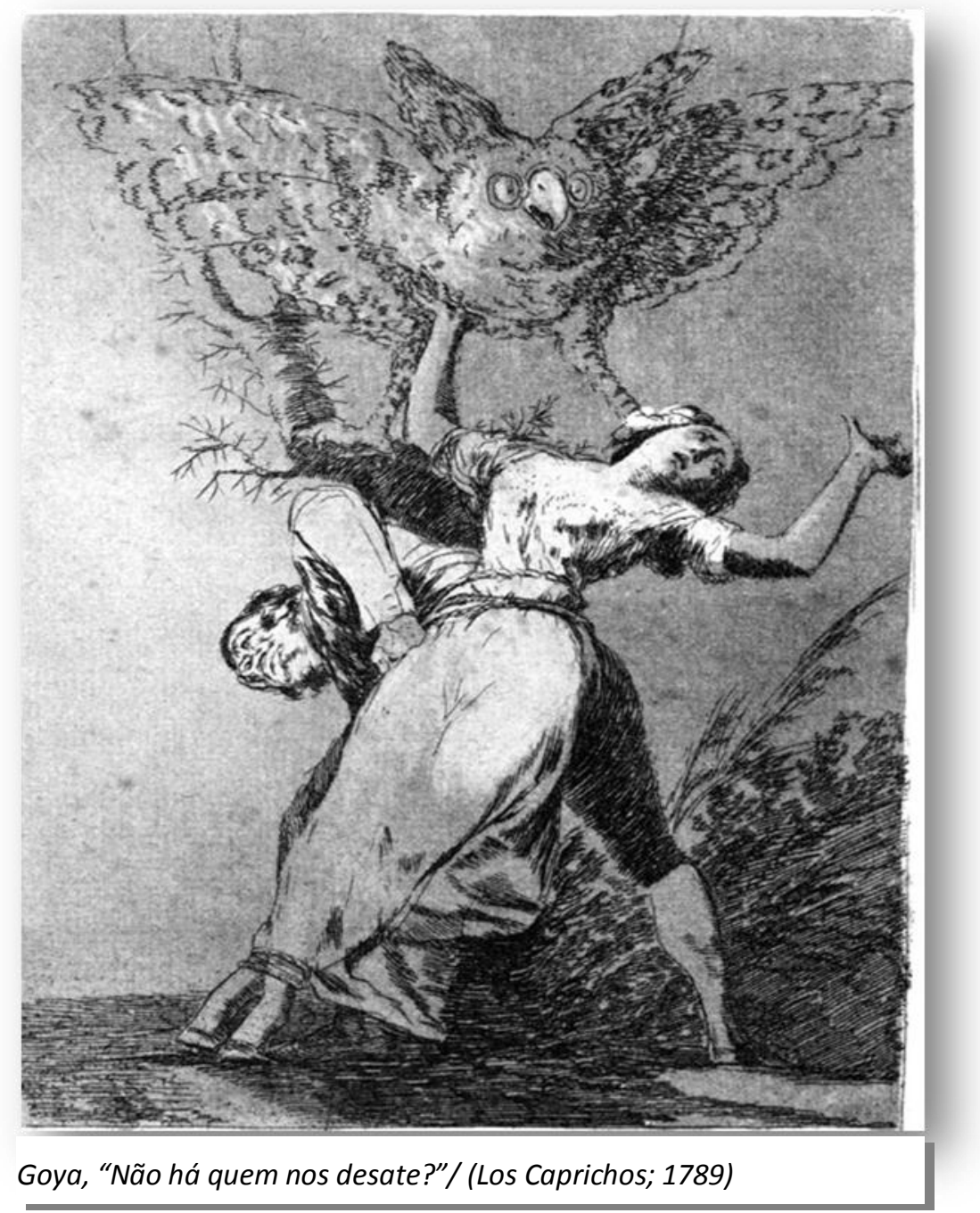




\title{
QUARTA PARTE
}

\section{A antecedência do processo}

\begin{abstract}
Até certa altura do segundo capítulo, o leitor vem pensando que as páginas escritas pelo personagem se amontoam ainda irreveladas, depositadas sobre a mesa, e que, antes de exibi-las, êle se estende relatando as peripécias da batalha criadora. (...) Paulo Honório redigia era as páginas que vínhamos lendo. ${ }^{106}$
\end{abstract}

Retomando a análise dos processos de enunciação suspendidos no capítulo 2, e que ressurgem no último capítulo de São Bernardo, resgatemos um dos fenômenos capitais e decisivos para boa parte das interpretações realizadas pela crítica até então. Rui Mourão nos fornece, acima, a síntese fundamental de todas elas, servindo-nos decisivamente aos propósitos de nossas reflexões e análise do percurso narrativo e discursivo, bem como do sentido produzido em dado momento da história do romance.

A cena de Paulo Honório - descrita pelo crítico - debruçado sobre as cópias ou páginas de um manuscrito e que, na projeção do futuro, se manifestaria como o próprio romance que acabamos lendo, nos favorece ao pôr em perspectiva a última imagem sugerida pelo texto antes de penetrarmos no capítulo 3. Pois, ao alcançarmos o capítulo 36, será nesse mesmo ponto e nessa mesma perspectiva que o encontraremos e onde se unirão personagem e narrador, fundidos numa unidade (romance) que, anteriormente, se desdobrava em duas faces distintas.

Até o capítulo 2, a expectativa gerada pela ideia de que o que estaríamos lendo seria o mesmo texto escrito por Paulo Honório (presente linguístico) opera-se pela similaridade do que ocorre no âmbito do enunciado, manifestando na dramatização o processo de elaboração mental, convertido em enunciação. Há, portanto, uma simetria entre o livro real (discurso) e um suposto livro, fictício, em processo de elaboração (narrativa). A sentença "Antes de iniciar este livro" é o eixo temporal da produção discursiva e, sendo um fenômeno linguístico, não pode ser localizado, segundo Benveniste, em nenhuma divisão particular do tempo crônico. Daí depender da decisão do intérprete os sentidos possíveis em dado momento da história e os supostos valores artísticos.

Isso tanto pode sugerir que o livro que começamos a ler é produto do escritor alagoano, análogo ao produto final do labor mental realizado por Paulo Honório, como pode

\footnotetext{
${ }^{106}$ MOURÃO, Rui. Estruturas, Ensaio sôbre o Romance de Graciliano. Rio de Janeiro: Arquivo Editora e Distribuidora, 1971. (Cf. pp. 58 e 59)
} 
ser interpretado haver um livro dentro da ficção (produto) cujo processo de escrita (produção) foi descrito apenas enquanto processo anterior ao trabalho do autor alagoano.

Nesse sentido, o trabalho reifica-se segundo o valor de troca do produto (nesse caso, falamos em valor simbólico artístico). Façamos, nesse caso, a distinção entre processo (correspondendo ao labor das articulações mentais ou do intelecto) e trabalho (correspondendo à força de produção cujo valor encontra-se no sistema de troca simbólica).

No primeiro caso, apenas teríamos simetria, cujo intervalo temporal (produzido pelo tempo dominante futuro do indicativo) entre a enunciação (presente) e o enunciado (passado) já estaria preenchido por uma concepção de romance (valor) preexistente e facilmente atribuída ao autor alagoano. Ora, ao se iniciar a descrição do processo de composição de tal livro, no capítulo 1, o enunciador desloca o objeto/livro para o passado, instaurando os atores da ação dramática, incluindo aí o narrador perspectivado na cena, num tempo cifrado como futuro do pretérito.

Compondo o cenário das atuações pela designação das funções que caberia a cada colaborador do projeto, descrevendo o plano inicial da composição, nos é dado um valor x de romance: produto, valor de troca (cujo valor simbólico seria "língua de Camões" (epopeia), romance moderno (realista-naturalista), modernista (língua falada). Mas tal projeto é abalado, ao final do capítulo, pelo desentendimento. Daí em diante o valor de troca (produto) é substituído por outro tipo de valor, determinado pelo pacto entre narrador e narratário segundo o "não valor" literário, mais ou menos com intuito de "falar a verdade" em detrimento daqueles padrões literários que acabariam por falsificá-la.

No início do capítulo 2, a cena que se nos apresenta é esta mesma que Rui Mourão nos fornece. Ela corresponde, na cadeia de cenas, à última posição do personagem, situada nos capítulos 1, 2, 19 e 36, ainda, "antes de iniciar este livro". E é nesta cena que ele começa, permanece e continua a enunciar o que "faria", o que pretende contar e como pretende organizar os fatos e elementos que vão surpreendentemente surgindo no processo.

Isto é, ainda não se poderia dizer que o livro que lemos é o mesmo. Ainda seriam necessárias outras evidências. Contudo, para Rui Mourão (assim como para Lafetá ou mesmo Abel Barros Baptista), bastou mencionar "os dois capítulos perdidos" para que se evidenciasse a ideia de que o livro mencionado na primeira sentença e o livro que pretende escrever Paulo Honório fossem os mesmos escritos. Assim sendo, os elementos intersubjetivos de cada uma das interpretações procedentes são os mesmos - e já analisados semioticamente aqui. Mas os valores atribuídos são diferentes, como se viu, e, descritos nas 
análises, vão ser tocados como "trabalho", dos anos de 1950 em diante, positivo. Mas, antes disso, de 1930 até os anos 40, é o motivo por qual a crítica vai julgar os processos narrativos de São Bernardo "inverossímeis", isto é, negativamente. Assim, o efeito produzido, de modo geral em São Bernardo, é o de que se iniciou na leitura o processo acabado do que o personagem está começando a fazer, ou melhor, mal começou e mal termina. Por isso não importa que ele repita, na cena, "ainda não principiei": a interpretação antecipa-se a ele, segundo valores pré-constituídos no circuito do valor simbólico literário, e destrói o intervalo existente entre enunciação e enunciado.

Com o preenchimento do vazio produzido entre o discurso (romance) e a enunciação de Paulo Honório (narrativa), segundo um valor (que tanto pode ser os sugeridos pela relação “língua de Camões"/língua falada como pelas próprias características do trabalho sugerido na narrativa), a consequência será de esmagamento de tudo o que for estranho à audiência.

Desse efeito ou ato interpretativo de dar um valor de literatura ao trabalho - quer dizer, ao que não é trabalho ainda, mas processo - surge o obscurecimento do labor mental, cujas articulações obedecem ao padrão do pensamento, segundo sua sintaxe e seu próprio manejo dos signos linguísticos disponíveis no léxico do narrador. Tal processo, anterior ao trabalho e ao produto, desaparece para dar lugar à atualização do leitor segundo o valor literário de sua expectativa. Essa atualização do leitor, reificado pelo produto (romance), determina o valor do trabalho: derivando-o do produto (romance do tipo x), existente no circuito das relações de troca simbólica em nível de circulação dos valores literários preexistentes na cultura, todo o restante de elementos inexistentes nesse padrão de literatura desaparece, dando origem ao que Iser chama de obra, isto é, "o ser constituído na mente do leitor". Retomaremos isso mais à frente. Por ora, vejamos outras cenas em que aparece o narrador à mesa, como as do capítulo 19:

Quando os grilos cantam, sento-me aqui à mesa da sala de jantar, bebo café, acendo o cachimbo. Às vezes as idéias não vêm, ou vêm muito numerosas - e a folha permanece meio escrita, como estava na véspera. Releio algumas linhas, que me desagradam. Não vale a pena tentar corrigi-las. Afasto o papel. (p. 101)

Essa presentificação do processo, em que lê e afasta o papel, dando continuidade à narrativa, se contrapõe ao que está sendo lido por ser já não mais uma folha meio escrita. $\mathrm{O}$ que se apresenta aí ainda é "antes de iniciar este livro", processo, o pensar antes do pensamento pronto, organizado, isto é, a descrição de um processamento de ideias que chegam numerosamente. E, muito embora essa folha permaneça meio escrita, já tomamos conhecimento de sua infância, de sua volta a Viçosa e de que, cinco anos depois, se tornou o 
proprietário de São Bernardo. É a continuação da cena do final do capítulo 2. E não há como saber o que há nessa folha meio escrita; só há como saber o que se passa pela cabeça do personagem-narrador como processo de elaboração mental.

Por esse motivo é que a paisagem, na viagem de trem, está deslocada de seu lugar: se o narrador decide omitir isso no papel, o discurso produzido desmente a omissão e a apresenta como um padrão descritivo atípico em literatura, inominável senão pela mesma relação de semelhança a outros processos de produção (o do engenho de açúcar, no caso, "bagaço", separado da matéria-prima). A paisagem aí não é apenas paisagem; é um componente da literatura que, destacado de seu lugar habitual segundo determinada convenção literária, não só é desnaturalizado como evidencia o artifício produtor do efeito de realismo na literatura. $\mathrm{E}$, mais ainda, como a construção acontece de forma antecedente, e à base do léxico do narrador, ela vai ser nomeada de "bagaço".

A descrição da elaboração mental de Paulo Honório, selecionando ou descartando elementos de sua memória, é convertida em discurso de um enunciador que se valeu do processo contrário ao dele, apresentando-o como um padrão diverso do que já era conhecido. Por isso concordamos com Rolando Morel Pinto quando este diz que a paisagem se incorpora à cena na medida em que é conveniente ou não para o leitor. Ela está lá, embora o narrador diga que não. Logo, a essa altura, já não se pode deduzir que há nessas folhas o mesmo que lemos: elas são o objeto da relação entre discurso e narrativa, correspondente ao "plano de escrita sendo processado pela inteligência" e esboçado pela imaginação, pelo pensamento, como passagem da mensagem 1, que pede o trabalho de ser transferida para o papel, à mensagem 2, conforme já dissemos no capítulo "A escrita utópica de Paulo Honório". É nesse intervalo de transferência que se encontra sua história.

Continuemos; Paulo Honório conta-nos, no capítulo 36, que

Faz dois anos que Madalena morreu, dois anos difíceis. E quando os amigos deixaram de vir discutir política, isto se tornou insuportável.

Foi aí que me surgiu a idéia esquisita de, com o auxílio de pessoas mais entendidas que eu, compor esta história. A idéia gorou, o que já declarei [final do cap. 1]. Há cerca de quatro meses, porém, enquanto escrevia a certo sujeito de Minas, recusando um negócio confuso de porcos e gado zebu, ouvi um grito de coruja e sobressaltei-me [início do cap. 2].

Era necessário mandar no dia seguinte Marciano ao forro da igreja.

De repente voltou-me a idéia de construir o livro. Assinei a carta ao homem dos porcos e, depois de vacilar um instante, porque nem sabia como começar a tarefa, redigi um capítulo [início do cap. 3].

Desde então procuro descascar fatos, aqui sentado à mesa da sala de jantar, fumando cachimbo e bebendo café, à hora em que os grilos cantam e a folhagem das laranjeiras se tinge de preto. (pp. 179 e 180)

Tal imbróglio temporal engana aos que interpretam aqueles "dois capítulos perdidos" como escrita de Paulo Honório: no capítulo 19 menciona "a página meio escrita"; no 36, a 
redação de um capítulo apenas, o que se passaria entre o fim do capítulo 2 e começo do 3. Isto é, a interpretação é infundada, já que ali temos três capítulos escritos. Por isso, o processo de enunciação não se confunde mais com o projeto ainda não começado da escrita (enunciado), tampouco com a narrativa que engloba os dois processos e os inclui à própria história do narrador. Ele já contou, já sabemos tudo. Ora, mas ele ainda não escreveu, motivando a continuação dos esforços intelectuais. Continua sentado à mesa dizendo para nós onde, quando e como está situado; a última cena mostra o personagem debruçado sobre a papelada praguejando, insultando os que estão dormindo. Segundo o intervalo temporal assinalado na enunciação, deveríamos terminar a leitura dizendo: "acabei de ler um livro que não foi escrito".

Isto implica dizer que, se não foi escrito, foi pensado, raciocinado; portanto, sendo Paulo Honório semialfabetizado, o que se passou ali foram, finalmente, os processos dedutivos de um autodidata concebendo um plano de escrita para a história que acaba de nos contar. Essa condição do narrador é que vai permitir a Graciliano Ramos explorar a diversidade de possibilidades existentes na circulação de elementos dos sistemas literários, distorcer padrões e apresentar seus artifícios; em suma, criticar o valor literário de determinadas manifestações no circuito das trocas simbólicas e certas práticas literárias, o que o faz um romancista moderno no sentido formulado por Erwin Theodor Rosenthal:

(...) O romance de hoje, adaptando-se às condições de nossa vida e ao caos moderno, questiona a nossa posição perante a realidade, e a maneira como se realiza o processo criador vem a ser mais importante do que a realidade visível (...). (ROSENTHAL, 1975: p. 70)

Por intuição, Paulo Honório chega a processos de elaboração literária inclusive consagrados num horizonte de expectativa, e que foram atribuídos, pela recepção, à personalidade deste ou daquele escritor. Para Graciliano, Paulo Honório é uma máscara ou um simulacro por qual opera e faz com que os processos dedutivos do narrador (o como), no momento de concepção da elaboração, aflorem em meio à narrativa, possibilitando que eles possam ser "visualizados", criticados ou assumidos na instância do discurso pelo enunciatário.

A crítica tem visto, desde suas primeiras manifestações no final de 1934, nesses quadros, uma espécie de "falha", inverossimilhança, do modo de compor de Graciliano por não perceber que ele se liga à arte moderna em termos de manifestação geral, não no sentido particular que cada país ou cultura a determinou. Como dissemos, a arte moderna não se reduz, em literatura, à invenção morfológica apenas, ou à inclusão (bem-sucedida) da língua oral na literatura; a arte moderna é uma experiência sensorial, e ela se realiza em São 
Bernardo no âmbito da linguagem literária, não da percepção da realidade. A partir daqui já é possível iniciar a compreensão do que a experiência sensorial da linguagem literária posta em perspectiva em São Bernardo produziu na crítica de 1934 até os anos de 1940.

\section{A teoria do romance em São Bernardo}

Vejamos. A citação que se segue é um pouco longa, mas de extrema necessidade aqui.

(...) nem a historia, nem o estylo, têm nada que se pareça com a maneira do autor da Ilustre Casa de Ramires. Se alguma influencia se observa, depois, é de Machado de Assis. “(...) Reproduzo o que julgo interessante. Suprimi diversas passagens, modifiquei outras. O discurso que atirei no mocinho do rubi, por exemplo, foi mais energico e mais extenso do que as linhas chôchas que ahi estão. A parte referente á enxaqueca de D. Gloria (e a enxaqueca occupou, sem exaggero, metade da viagem) virou fumaça. Cortei igualmente, na cópia, numerosas tolices ditas por mim e por D. Gloria.

Ficaram muitas, as que minhas luzes não alcançaram e as que me pareceram uteis. E' o processo que adopto: extraio dos acontecimentos algumas parcellas; o resto é bagaço."

E, no fim do capitulo: "Vou dividir um capitulo em dois. Realmente o que se segue podia encaixarse no que procurei expôr antes dessa digressão. Mas não tem duvida, faço um capitulo especial por causa de D. Magdalena".

Mas isto é Machado de Assis!

Vamos deixar de parte a incoherencia de Paulo Honorio, confessando afinal, que não se escreve tudo quanto se fala. A respeito da eliminação do superfluo, escreveu Braz Cubas: "Sabido que reli a carta, antes e depois do almoço, sabido fica que almocei, e só resta dizer que essa refeição foi das mais parcas da minha vida..."

E, mais adeante: "Mas, ou muito me engano, ou acabo de escrever um capitulo inutil". Ou então: "Não: decididamente suprimo este capitulo". E ainda: "Convém intercalar este capitulo entre a primeira oração (...). ${ }^{107}$

Os elementos selecionados pelo crítico, aqui, são os mesmos do texto, compreendidos por Iser como intersubjetivos. E, ainda que nos anos de 1930 produzam a mesma ilusão de que o que estamos lendo no romance é o que está "na cópia" referida pelo narrador, é do valor negativo, evocado pela norma padrão-literário dominante no horizonte de expectativas, que se vai ocupar a crítica. Assim, arrisquemo-nos a dizer, São Bernardo vem sendo compreendido há quase 80 anos. Parece que os observadores, afeitos àquilo que Graciliano considerou, em Memórias do Cárcere, "isenção de emoção", observando Sérgio fazer a leitura de seu romance, dão os contornos de uma maneira de fazer a crítica ainda hoje muitíssimo viva.

107 BARROS, Jayme de. 02/03/1935. Negrito do colunista. Os artigos publicados em revistas e jornais analisados doravante estão transcritos na íntegra no final deste trabalho. A referência completa de suas localizações encontra-se junto ao capítulo das transcrições feitas ao longo da pesquisa. Mencionaremos apenas o nome do autor e a data de publicação: a transcrição dos escritos segue a ordem cronológica de aparição na imprensa. 
A única diferença, portanto, considerando apenas esse aspecto, é que o valor positivo com o qual estamos acostumados não existe antes dos anos de 1950. Isto é, o processo de realização literária não tinha como referência a ficcionalidade do texto, muito embora, por exemplo, Carlos Lacerda, ao discutir o mesmo problema, tenha dito que "os homens estavam esbarrando num dilema excessivamente literário". Mas faltou ao jovem crítico apreender certos detalhes que o levariam ao ficcional do texto, o que não acontece por força do ambiente de então.

Graciliano nos conta que são "os detalhes que o prendem" na composição. E parece que o detalhe da comparação com Machado é que, enquanto a referência de Brás Cubas são os capítulos do livro do escritor carioca, motivado pelo uso do tempo verbal, as referências de Paulo Honório estão no intervalo entre a memória (narrativa) e a menção da cópia sobre a mesa (enunciação-enunciada), em função do tempo futuro, abrindo um intervalo entre esses dois níveis e que só pode ser apreendido como processo.

Mas a comparação, no entanto, é válida: revela, na verdade, numa instância superior de análise, que Graciliano está incitando o leitor a criticar a noção de que o processo de composição atribuído a Machado de Assis, como personificação de um estilo, valor literário, não é uma particularidade do escritor carioca. Paulo Honório, sendo declaradamente incapaz de escrever, tendo declarado não entender nada sobre literatura, demonstra que intuitivamente é capaz de imaginar o que o bacharel Brás Cubas realiza, sem depender do conhecimento prévio da literatura.

Isto é, tal processo é possível a quaisquer que sejam os escritores porque se trata de uma articulação mental anterior ao trabalho e ao produto final, que não pode ser tomado como trabalho em si nem como produto, mas condição de surgimento destas duas coisas: um processo anterior à escrita.

E a incoerência atribuída ao narrador, relacionada à escrita realizada, põe em contraste o modo adotado pelo narrador (omitir) em oposição explícita ao que se fez de fato discursivamente (apresentar); exatamente porque tal processo, considerado "bagaço" por Paulo Honório, e que, portanto, não deveria aparecer na leitura, não o foi para Graciliano Ramos: o que enuncia Paulo Honório, no interior do enunciado, é o inverso do que realiza o escritor alagoano. O "bagaço" é, assim, parte da estrutura de São Bernardo e surge em perspectiva de elaboração literária diversa: a paisagem deslocada da cena da viagem de trem para a memória de Paulo Honório não deixa de ser descrição da paisagem. 
No entanto, essa forma não tem a menor semelhança com o modo de construir os cenários em Machado de Assis. É de todo sabido o que Graciliano pensava a respeito disso:

É admirável. Há imitadores de Machado de Assis porque escreveram contos, outros porque são funcionários públicos, têm doenças ou gramaticam demais os seus produtos. Está certo. Que remédio? (RAMOS, 1979: p. 110)

É uma crítica extremamente ácida: significa dizer basicamente que o gênero, a norma, em suma, os elementos comuns dos sistemas literários são tomados como particular quando não o são absolutamente. Graciliano jamais diria "nunca li Machado de Assis ${ }^{108 ",}$ como o fizera, ou qualquer autor o diria, senão como exigência de uma solução, à crítica, que não fosse responder meramente "Isto é Machado de Assis". Parece que Graciliano percebeu claramente o fato de que "a obra" produzia o "nome", e que havia uma incoerência aí; a saber, a ilusão de que esse nome seria anterior ao processo da obra quando, em verdade, a obra ocasionava o nome.

É muito provável que as crônicas "Machado de Assis" e "Os Amigos de Machado de Assis" tenham como fundamento suas próprias experiências com a recepção de Caetés e São Bernardo. As comparações com Eça de Queiroz surgem em 1933 com a publicação do primeiro romance; com Machado de Assis começam a surgir exatamente com a publicação de São Bernardo. As duas crônicas vêm logo após Graciliano sair da prisão em 1937. Além disso, escreveu uma carta claramente alusiva ao fato de Paulo Honório ter-se limitado à escrita de apenas "um capítulo" ou uma "carta a certo mineiro".

Ló: No último capítulo do S. Bernardo o nosso amigo Paulo Honório escreve uma carta a certo sujeito de Minas, sobre um negócio confuso de porcos e gado zebu, se não estou enganado. Ou só de porcos: parece que no livro não se fala em gado zebu. Só vendo. Pois eu agora acabo de escrever duas cartas a dois sujeitos de Minas, sobre o mencionado Paulo Honório. Não tratei de porcos - só de literatura. Os dois sujeitos são o Oscar Mendes e o Jaime de Barros (... $)^{109}$

A carta de Graciliano refere-se às duas críticas publicadas em Minas Gerais e transcritas aqui. Ambos os críticos julgaram inverossímil que Paulo Honório fosse o escritorficcional. Ora, embora com ironia, indiretamente Graciliano distingue-se de seu personagem por escrever sobre literatura, enquanto ele, sobre "um negócio confuso de porcos e gado zebu": leva em consideração, para que se interprete a "escrita do personagem", o tempo passado. Sabendo-se ainda da atenção do escritor alagoano dada a detalhes aparentemente insignificantes é que compreendemos o motivo de ele atribuir a si mesmo a dúvida de haver

${ }^{108}$ LINS, Álvaro. O Romance Brasileiro Contemporâneo / Rio de Janeiro: Edições de Ouro, 1968. (Cf. p. 62) Conta-nos o crítico que, ao se perguntar a Graciliano sobre "ter lido Machado de Assis", o romancista alagoano negava, dizendo: "Nunca li".

${ }^{109}$ RAMOS, Graciliano. Cartas / Rio de Janeiro: Ed. Record, 1992. (Cf. p. 146) 
ou não o mencionado gado zebu no episódio (uma ironia esplêndida, já que alude certa atitude de descuido, de confundir o que foi imaginado com o que foi escrito por ele mesmo). Isto é, ele desloca a atenção a um detalhe aparentemente insignificante, que nenhum dos críticos toca, para conotativa e ironicamente exemplificar que "há um detalhe" ali que eles não percebem ao atribuir a Paulo Honório a escrita do livro.

O caso é que vamos chegar às últimas páginas de São Bernardo sem que, de fato, se faça a menor menção de que o que tínhamos lido eram as páginas, cópias etc., que estão sobre a mesa: "Lá fora uma treva dos diabos", "Estão todos dormindo", e termina o romance: "E eu vou ficar aqui, às escuras, até não sei que hora, até que, morto de fadiga, encoste a cabeça à mesa e descanse uns minutos". Isto é, "antes de iniciar este livro". Isto o difere do processo de Memórias Póstumas, em que o narrador, personagem-autor, faz referências diretas aos capítulos anteriores, indicando a passagem a que se refere (podendo ser conferidas retroativamente). Em São Bernardo, tudo é projetado para o futuro, em prospecção, não sendo, pois, possível retroagir e conferir as referências em termos de uma escrita realizada, só há como fazer relações. Tampouco se pode dizer que, depois que ele encostou a cabeça e descansou por alguns minutos, acordou e deu continuidade ao que acabamos lendo. Isso não seria interpretação do texto, mas uma deturpação do que está concretamente realizado.

Aliás, se isso tivesse sido escrito, aí sim poderíamos apontar incoerência e dar a Jayme de Barros a razão, quando afirma que existe uma "(...) incoherencia de Paulo Honorio, confessando afinal, que se não escreve tudo quanto se fala". Ocorre, pelo contrário, que ele pode falar tudo exatamente porque não está escrevendo, está pensando no que e como vai escrever. Isso jamais foi analisado. Mas a crítica surgida a partir da publicação do romance, porque envolvida num horizonte de expectativas dominante, não só foi unânime no sentido de imediatamente perceber o processo e avaliá-lo como inverossímil como nem mesmo chegou a mencionar o que nos esforçamos aqui para explicar, esforço que vem sendo feito desde Ficção e Confissão. É quase unânime, nas décadas de 30 e 40, que

Infelizmente, em S. Bernardo, houve um erro de techinica: Paulo Honorio não convence ninguem, com seu espirito acanhado, de horizonte curto, sua mentalidade pouco cultivada, de que seria capaz de escrever este livro, que é um dos melhores romances aqui apparecidos nos ultimos tempos. Vê-se logo que quem o escreveu foi mesmo o sr. Graciliano Ramos, e que elle não é Paulo Honorio. ${ }^{110}$

Curiosamente, o que a crítica atual se esforça para não dizer (que Graciliano escreveu o romance) é dito com muita naturalidade durante os anos 30, o que poderia induzirnos a caracterizá-la como ingênua. Mas é importante considerar que outro viés de leitura não 
seria possível dentro daquele panorama histórico, permeado por um horizonte de expectativas em que o familiar, para o leitor de 1930, tinha caráter dominante, tendo sido elevado à categoria de modelo nacional, em oposição ao estrangeiro, pela relativa descoberta de Machado de Assis como romancista pioneiro em termos de abertura de um novo caminho para a literatura brasileira e contra as tendências modernistas. Atribuir a Graciliano a escrita, neste caso, implica dizer exatamente que se trata de

Livro attrahente mas semeado de surpresas desagradaveis, pois que a grosseria, com que tratava a esposa e os amigos, o heróe a estende tambem aos leitores. O palavrão, aspero e obsceno, salta-lhe da bocca na presença de quem quer que seja. E' verdade que o leitor moderno, maxime se é frequentador das rodas que dão ao tom na sociedade, deve estar familiarisado com palavrões. Talvez não tenha, por isso, as surpresas de que o adverti. Tanto melhor. ${ }^{111}$

Há certa sutileza em Jayme de Barros quando atribui a escrita a Graciliano Ramos. Conforme o mesmo horizonte de expectativas do crítico paulista, referindo-se ao leitor moderno, também Franz Martins vai criticar a linguagem do romance:

O construtor de "S. Bernardo", porém, não soube higienisar o seu livro - e quando dizemos higienisar não é no sentido de fazer do romance um breviario mistico e carola, mas sim um livro que, em todas as suas paginas, honre a literatura sertanista do Brasil ou, pelo menos, procure desfazer a impressão, já bastante arraigada, de que toda obra regional só é perfeita quando encerra capitulos que não possam ser lidos em voz alta ou por pessôas serias. ${ }^{112}$

O impacto ocasionado por São Bernardo na crítica revela o horizonte de expectativas e nos permite compreender sua procedência.

As normas selecionadas de realidade extratextuais e as alusões literárias enquanto elementos centrais do repertório do texto são tirados de dois sistemas diferentes. O primeiro vem dos sistemas epocais de sentido, o outro do arsenal dos padrões de articulação, através dos quais a reação dos textos a seus ambientes é formulada na literatura do passado. (ISER, 1996: p. 150)

Ora, é o que ocorre com São Bernardo. Há um sistema de sentido literário compondo o ambiente histórico de produção do texto, o Modernismo, cujo repertório de elementos, enquanto proposta, não se encontra intraliterariamente disponibilizado em forma sistemática de literatura. O que a História da Literatura nos oferece mais ou menos de forma estanque, nesse momento, ainda se encontra no seio social, "máxime se é frequentador das rodas que dão ao tom na sociedade”. E se dos anos de 1950 até hoje a ideia de escrita de Paulo Honório tem de ser provada, pois ela se constitui o valor positivo da obra, nos anos de 1930 e 40, além de esse aspecto ser explícito, não se discutia nem havia um esforço de ser provado: era um

\footnotetext{
111 BARRETO, Plinio. 05/01/1935

${ }^{112}$ MARTINS, Franz. 06/03/1935
} 
valor negativo. Não foi à toa que Graciliano respondeu às críticas de Oscar Mendes e Jayme de Barros.

O Modernismo ainda não tinha um sistema de referências literárias pronto, em circulação sistêmica autor/obra/público: é um repertório extratextual (circulando como proposta ou ideias ainda não realizadas, não formuladas numa literatura corrente em termos de prosa). Daí se segue o direito permanente à pesquisa estética. Daí ser praticamente impossível romper completamente com a literatura do passado nesse momento e que surge na figura agigantada de Machado de Assis: são duas forças conflitantes ainda. Por isso São Bernardo mantém o familiar com a norma, "deformando-o" pela perspectiva de um narrador sui generis.

(...) 1. É através da desvalorização do familiar que o leitor se torna consciente da situação familiar que orientava a aplicação da norma agora desvalorizada. 2. A desvalorização da norma marca um ponto culminante, que introduz o familiar na memória, que orienta a busca pelo sistema de equivalência do texto à medida que esse sistema deve ser constituído em oposição à memória, ou diante dela. ${ }^{113}$

É nesse sentido que dissemos, no início deste trabalho, que a relação especular entre o discurso (romance realizado) e a enunciação do narrador (processo em andamento, romance não realizado) tinha como intento comunicar ao leitor os meios de constituição do sentido em oposição aos valores pré-constituídos (interiorizados na memória) por uma praxe de leitura anterior à leitura propriamente dita: a perspectivação do horizonte de leitura no interior do enunciado (aqui chamado de dramatização de convenções literárias) permite ao leitor perceber a normatividade do já familiarizado como meio de interpretação literária dominante numa época.

$\mathrm{O}$ que Valentim Facioli identificou como "um permanente desencontro entre o narrador e o personagem" é exatamente o fato de esse efeito continuar ainda hoje vibrando, de não haver correspondência exata entre o familiar e o que estava sendo proposto a partir de sua deformação: Paulo Honório personifica a deformidade da categoria normativa de autorfictício apenas no momento em que a norma de composição literária dominante no horizonte de expectativas apresenta um padrão sistêmico positivo que ainda não coabita com outros horizontes. E nas décadas de 1930 e 40, até aí, jamais se admitiu a verossimilhança do narrador de São Bernardo; é só a partir da década de 1950 que ele é admitido como escritorfictício verossímil. Por tal motivo deixamos este recorte temporal da recepção para ser abordado no estágio final de nosso trabalho.

${ }^{113}$ Idem, p. 152 
Essa é a diferença, inclusive, entre esse romance e Caetés; neste último, a correspondência ao que era familiar, segundo o repertório de significação da audiência, público leitor de 30, não ocasionara nenhuma perturbação no familiar, nenhum estranhamento; portanto, as comparações com A Ilustre Casa de Ramires, segundo as normas, tinham consistência.

É evidente que o estilo de Graciliano já estava patente ali; mas um estilo novo não requer uma ruptura com normas de significação, tampouco com o horizonte de expectativas. Somente as rupturas ou deformações das normas, do que é familiar nos sistemas extra e intraliterários, propõem algo novo. E é isso que ocorre com São Bernardo. No final de Caetés, por exemplo, João Valério termina suas considerações sobre seu romance histórico dizendo que os selvagens são todos eles - talvez se relacionando ao Romantismo e ao Modernismo no âmbito do nacionalismo, da independência, no XIX, e a sua comemoração no XX, a partir de uma semelhança extraordinária com o que fazia Eça de Queiroz. Em São Bernardo, de modo inesperado e incompreensível até, Paulo Honório diz: "Julgo que delirei e sonhei com atoleiros, rios cheios e uma figura de lobisomem" (p. 188). Ao canibalismo dos caetés é contraposto o dos cinocéfalos.

Essa figura da aberração, sobrenatural, imaterial, não pode ser associada a nada que se havia feito em literatura ou que circulasse já no sistema de valor: o romance propõe algo novo. Essa imagem é tão inesperada que pouco se tem refletido a respeito dela, por maior que seja o esforço de interpretá-la. Embora mantenha certa ligação muito distante com o estilo de finalização de obras realizado por Eça, há uma espécie de rompimento do sentido pelo fato de não se deixar penetrar por outra consciência interpretativa senão a do próprio protagonista e de seu sistema de significação imanente.

As escolhas de características do personagem-autor Paulo Honório são as estratégias do texto, cuja finalidade é a de produzir certo efeito no contexto de sua circulação; no mínimo o efeito de estranhamento e reflexão em relação ao que era familiar e facilmente relacionado a outros autores ou movimentos literários. Paulo Honório nem é analfabeto (o que inviabilizaria o trabalho) nem Modernista; nem possui as competências literárias para realizar o intento (o que o tornaria familiar). Ele ora remete a uma convenção literária, aparentemente, ora a outra, mas a nenhuma se adéqua. Está em meio caminho de tudo e não é nada ao mesmo tempo. É capaz de, como ele próprio diz - aliás, uma característica de quem foi semialfabetizado e é autodidata - “(...) plantar mamona, levantar a serraria e o descaroçador, introduzir nestas 
brenhas a pomicultura e a avicultura (...). Tudo isso é fácil quando está terminado e embirrase em duas linhas (...)" (p. 11)

Essa característica é fundamental, cujo fim é o de, na perspectivação do narrador na cena de suas reviravoltas com o processo de transferência de suas ideias para o papel, mantêlo na mesma posição que vamos encontrá-lo no capítulo 2, no 19 e no 36.

Se compararmos esse aspecto de sua capacidade aos saltos quilométricos, de capítulos a capítulos, de nosso simpático Brás Cubas, percebemos a enorme diferença entre os dois: é exatamente esse detalhe que vai manter a coerência ou estabilidade das referências do texto e o distanciamento da norma. O trecho extraído por Jayme de Barros foi frequentemente aludido por outros críticos, como Octávio Tarquinio de Sousa, como referência de estilo do próprio Graciliano reproduzindo Machado de Assis. A norma e a aparência com a norma em São Bernardo foi o que ocasionou a aproximação e impediu a ruptura desse livro com tudo que se praticava antes e o estabilizou no sistema de obras que circulam na literatura até hoje.

O efeito pode ser percebido, no capítulo 2, pelo fato de Paulo Honório achincalhar a linguagem literária do Gondim e parecer valorizar "a língua falada". Aí é o Modernismo que estabiliza o texto e impede a ruptura da obra com esse público. E assim ocorre em diversos momentos. Exatamente como um cubo de perspectivas possíveis girando a cada horizonte de expectativas provável, ou já realizado no sistema literário em circulação ou que poderia ser realizado futuramente.

Essa característica é que vai permitir que a identidade das ideias de Paulo Honório (o fluxo de seu pensamento) se ofereça ao leitor segundo o horizonte de expectativas constituído no final do XIX e vigente na primeira metade do século XX; o estranhamento, nesse caso, tanto poderia atingir o sistema de referência existente (o que parece não ter ocorrido) como inflectir-se sobre o texto (o que ocorre). Tal estranhamento evidenciou-se nas manifestações da crítica:

\footnotetext{
O protagonista parece-nos muito lucido, muito abundante em commentarios, o que é estranhável em creatura de poucas lettras, oriunda de ambientes agrestes, não afinada pela leitura de psychologos e romancistas introspectivos. ${ }^{114}$
}

No caso de Agrippino Grieco, a relação se estabeleceu entre a literatura (em que jamais, segundo consta, houve personagem-autor-fictício nesses moldes) e a referência sociológica fora do sistema literário, produzido num sentido naturalista ou realista. A finalidade, provavelmente, era pôr em dúvida um sistema estável de categorias literárias,

\footnotetext{
${ }^{114}$ GRIECO, Agrippino. $30 / 12$ /1934.
} 
propondo uma possibilidade nova, mas que esbarrou num horizonte de expectativa mais abrangente do se supunha, dominante ainda nesse período enquanto norma:

(...) o pobre, a despeito de aparecer idealizado em certos aspectos, ainda é visto como um ser humano meio de segunda categoria, simples demais, incapaz de ter pensamentos demasiadamente complexos lembre-se de que a crítica achou inverossímil que Paulo Honório fosse o sofisticado narrador de $S$. Bernardo. ${ }^{115}$ (BUENO, 2006: p. 24)

Há nessa década a concordância total de que o processo narrativo é inverossímil segundo esse critério, enquanto forma. Mas, em termos de conteúdo, o drama, a crítica é unânime em valorizá-lo, divergindo apenas ideologicamente conforme as posições políticas ou estéticas de cada crítico em particular. Por isso o que muda a partir dos anos de 1950 não é que Paulo Honório passa a ser verossímil em termos literários, mas sociologicamente.

Segundo as propostas modernistas, Paulo Honório dramatiza a pesquisa de uma possível origem nacional completamente atípica: nesse caso, a pesquisa da organização mental do jagunço, do cangaceiro, cuja raiz profunda se encontraria no coronelismo formado no Período Colonial, que poderia revelar particularidades a serem desenvolvidas segundo a tradição oral. Aliás, é o que o próprio Graciliano vai fazer ao participar da revista Cultura Política, tendo publicado posteriormente, em 1962, as crônicas ali produzidas em Viventes das Alagoas.

A tese defendida aqui é que os processos de dramatização do texto continham a descrição dos efeitos sobre a crítica (personificada como "leitor" ou horizonte de expectativas) em busca do familiar ou daquilo que ela antecipa e que de modo algum estaria no texto. Pensemos que Paulo Honório personifique um tipo de recepção (o leitor ingênuo ou insuficiente). Assim, no momento do encontro da carta escrita por Madalena, está descrito, em termos dramáticos, as influências de uma busca pelo familiar produzindo um efeito de leitura "desviante" da verdade ou do verdadeiro sentido.

Quando Paulo Honório identifica, na carta, o gênero masculino e, a partir disso, acredita ter encontrado a prova da traição de Madalena, interpreta mal e constrói todo o resto à mercê da intenção de Madalena ou do próprio texto (a leitura da carta, com apuro, revelaria o plano do suicídio). Para o Paulo Honório leitor bastou que a carta fosse destinada a um homem para significar o que ele queria que significasse. É o mesmo que acontece com Jayme de Barros, na citação, das semelhanças entre Machado e Graciliano: bastou a aparência com um sistema de norma familiar para deduzir todo o resto, anulando o próprio processo do texto

\footnotetext{
${ }^{115}$ BUENO, Luís. Uma História do Romance de 30 / São Paulo: Edusp; Campinas: Ed. da Unicamp, 2006. (Cf. p. 24)
} 
escrito, segundo sua especificidade e que ele mesmo, ironicamente, acaba dizendo que “Graciliano não é Paulo Honório".

O mesmo estranhamento deveria ter produzido a personagem Madalena. Ela é dramaticamente uma ficção das ilusões românticas (no sentido de seu idealismo inócuo e mascarador da realidade palpável dos dramas humanos): apesar de sua delicadeza e de sua aparente compaixão pelos menos favorecidos, ela manifesta uma forte indiferença em relação a seu filho. E a intenção dessa construção é, naturalmente, produzir o estranhamento, a reflexão e a análise de suas concepções. O que alguns quase chegaram a fazer, como Lúcia Miguel Pereira: "Há um quê de misterioso nessa mulher que se casa por dinheiro e tem idéias socialistas, que se descuida do filho e vive preocupada em suavizar a miséria dos moradores de S. Bernardo. Parece haver muito de intelectual em suas teorias e na sua bondade, mas não se sabe ao certo." 116 E, pelo fato de que "suas teorias" se manifestem sob a orientação de determinadas convenções literárias, seus embaraços podem ser vislumbrados a partir da ficção que tais convenções produzem em detrimento do conhecimento concreto da realidade material e histórica.

Lembremo-nos que, quando Gondim apresenta aquele feixe de elementos literários convencionais, vai acrescentar ao final deles - caso Madalena não se convencesse a ser professora de São Bernardo - o "nacionalismo". Tal motivo localiza o gênero romântico exatamente no período histórico de que ora tratamos. Parece que o Romantismo, nesse período, como Madalena, não deixa de ter como fundamento as concepções burguesas que lhe deram origem, acrescentando nele o nacionalismo em forma de proletarização. Exatamente o que ocorre com Madalena: após deparar-se com a realidade nada idílica do campo, em vez de lhe compreender os fundamentos, ela vai se empregar como funcionária de Paulo Honório. Isso é característico nos anos 30: muitos romancistas apenas proletarizaram seus heróis burgueses em função de que os fundamentos de suas concepções se encontravam na raiz da revolução burguesa e delas nunca poderiam deixar de prescindir.

Assim, tal perspectivação tem como finalidade orientar a leitura, permitindo que tais normas literárias sejam percebidas como valores preestabelecidos, cuja projeção sobre uma determinada realidade - por exemplo, a trajetória de Paulo Honório - impediria a compreensão dos valores autênticos de sua orientação (independentemente de gostarmos ou não dele, isso não importa enquanto princípio de análise). Seria, portanto, necessário inverter

\footnotetext{
${ }^{116}$ In: PEREIRA, Lúcia Miguel. A Leitora e Seus Personagens: seleta de textos publicados em periódicos (19311943), e em livros / Rio de Janeiro: Graphia Editorial, 1992. Esse artigo também foi aqui transcrito, segundo sua data de publicação: 24/12/1934.
} 
as perspectivas a fim de dar origem a algo genuinamente nacional. Em vez da perspectiva idealizante de Madalena, o ponto de vista brutal de Paulo Honório ou do coronel constituindose e oferecendo-se inconscientemente.

São Bernardo é um romance das ilusões sob todos os aspectos. Ele próprio não pode ser apreendido como a verdade sobre a ilusão. Mas sim a construção ficcional em busca das matrizes das ilusões referenciais do gênero. Sua proximidade está mais para o que produziu Oswald de Andrade do que para o produzido no século XIX. As diferenças entre Oswald e Graciliano apenas se manifestam no sentido de que o primeiro satirizou as ilusões produzidas pelas convenções preestabelecidas, mostrando-as jocosas, monótonas, burguesas, interessadas apenas por aspectos ligeiros. Graciliano, ao contrário, mantendo o familiar, a sensação de realismo, deforma o real aparente e o mostra artificial sob algumas orientações convencionais da literatura. A desvalorização radical do passado produzida por Oswald em sua obra a leva a se abrir rapidamente à percepção (do leitor moderno) por se apresentar como linguagem. Em São Bernarrdo, Graciliano "vestiu” as linguagens literárias com a roupagem de personagem a fim de apresentá-las como efeito. É nesse sentido que elas são dramatizadas no texto.

A desvalorização, em Graciliano, é produzida por trazer para o horizonte de perspectivas do texto o familiar - através das relações com o inesperado, o estranho, convertido pela lembrança de algo familiar -, que estabiliza o conflito de normas, permitido pelos intervalos em que se dá a relação e em que se infiltram as interpretações aparentemente corretas, segundo a norma dominante de uma época. Porém esse processo fica infectado pela relação, ad infinitum, mostrando a reflexão produzida na experiência da leitura, instaurando as dúvidas segundo o enorme número de contradições perceptíveis na cadeia da recepção; como na metáfora de Antonio Candido, do "sulco aberto no espírito pelas grandes obras" - a que acrescentamos a ideia de que nesse sulco imprimem-se os contornos da forma que por ali passou -, pode-se dizer que elas quase sempre se manifestam em termos de contradição, incoerência, desencontro, paradoxo e, sobretudo, inverossimilhança, verossimilhança. $\mathrm{O}$ que significa que não são leituras erradas, mas marcas da forma e da estrutura do texto de Graciliano. Esses elementos de fato estão lá; o que nos afasta do texto é a tentativa de conciliá-los aos padrões existentes, ou seja, qualquer tentativa de resolver o conflito transforma a solução do autor Graciliano Ramos em problema.

Se a crítica se liberta dos preceitos consagrados pela história da literatura como valor literário, chega ao fim de um romance, como São Bernardo, e percebe: “Acabo de ler um livro que nunca foi escrito", correspondendo apenas a uma série de perspectivas possíveis de 
realização anterior ao processo consagrado como igual ao que realizou Graciliano Ramos. Se não se liberta do senso das convenções, fecha o campo de possibilidade e radicaliza-o pela repetição dos mesmos valores pré-figurados no sistema vigente das normas epocais. Não se enxergou, por exemplo, em São Bernardo, as tão famosas dicotomias de nossa época: animalização do homem versus humanização dos bichos. Pelo contrário. Foi da humanização da literatura que mais se falou. A animalização é posterior. E, reunidas no nosso horizonte de compreensão, produzem a unificação da obra, ocasionando pequenas anacronias. Veremos mais à frente esse caráter como fronteira entre os diferentes livros.

No início deste trabalho, falávamos sobre responder à pergunta "Então pra que escreve?", cuja resposta é "Sei lá! O pior é que já estraguei diversas folhas e ainda não principiei". Essa suspensão do princípio, já estudada, separa o "produto" da relação extremamente íntima que mantém com o "trabalho que ganha existência valorativa através dele, do produto," no âmbito da circulação do valor cultural. As categorias são naturalmente marxistas, como as são as relacionadas no primeiro capítulo de São Bernardo, em que o objeto-valor "livro" surge no enunciado, como "valor de troca", produzindo a disforia com o leitor ou o implicando - por contraste na estrutura sintática da narração - um leitor cuja préconcepção valorativa de "obra" seria a de que ela não se reduz ao valor mercantil. Na sua Semiótica do Romance, Kristeva fala exatamente que

\footnotetext{
A análise marxista trata o valor de troca, isto é, o produto do trabalho posto em circulação: o trabalho entra no sistema capitalista como valor (= quantum de trabalho), e é enquanto tal que Marx analisa a sua combinatória (força de trabalho, trabalhadores, patrões, objecto de produção, instrumento de produção). (KRISTEVA, 1977: p. 29)
}

Nesse espaço, percebe Kristeva que o trabalho é "reificado" e propõe "Tal concepção do trabalho, tirada do espaço em que é produzida, isto é, do espaço capitalista" "117, evidentemente relacionando-a ao "trabalho do pensamento" e à "produção escrita", posta em circulação nas interações sociais em termos de troca simbólica e de valor cultural (ser literatura). São Bernardo, do modo como o vemos construído, parece-nos dizer literalmente o que Kristeva propõe como estudo semiótico, ou uma ciência do discurso. Inclusive, a semelhança é notável. Diz ela que "Freud (...) foi o primeiro a pensar o trabalho constitutivo da significação anterior ao sentido produzido e/ou ao discurso representativo: o mecanismo do sonho". Continua mais à frente: "Freud revela a própria produção enquanto processo, não de troca (ou de uso) de um sentido (de um valor), mas de jogo permutativo modelando a própria

${ }^{117}$ Idem, p. 30. 
produção". ${ }^{118}$ É evidente que a semioticista vai diferir o "trabalho do sonho" do "trabalho acordado" e, finalmente, o "trabalho", como o "pensamento", antes do "pensar". Ou seja, o processo que dá origem ao trabalho, escrita, retirando-o do universo do produto e de seu valor virtual nas trocas simbólicas, que seria assim o lugar de estudo da semiótica. Por isso ela denomina narrativa, processo, e romance, produto, como um duplo estatuto semiótico. Portanto,

Todo texto "literário" pode ser encarado como produtividade. Ora, a história literária, desde o fim do século XIX, oferece textos modernos que, nas suas estruturas, se pensam como produção irredutível à representação (Joyce, Mallarmé, Lautréamont, Roussel). Assim, uma semiótica da produção deverá abordar esses textos, justamente para juntar uma prática escritural voltada para a sua produção a um pensamento científico em busca da produção. (KRISTEVA, 1977: p. 35)

Cremos que não seja necessário irmos além. Parece-nos bastante claro que ao final de São Bernardo, quando Paulo Honório narrador diz "Julgo que sonhei com atoleiros, rios cheios e uma figura de lobisomem", isso discursivamente se refira a todo o processo narrativo sendo concebido como "processo do pensar", semelhante a um sonho (pesadelo) anterior ao "produto do trabalho" antecipado pela crítica de modo geral como "livro" em termos de representação. E é pelo fato de o processo ser irredutível à representação que, por exemplo, o termo "bagaço", usado por Paulo Honório narrativamente e associado à representação discursivamente, dimensiona-se em nível de processo (retirando seu sentido de outro sistema produtivo, o engenho de açúcar) a fim de nomear o inominável. ${ }^{119}$

Tal estratégia não teria sido possível antes das vanguardas, sobretudo das que se baseavam nos estudos freudianos, como o de Breton. Daí São Bernardo ser o divisor de águas do percurso literário de Graciliano Ramos. Esse romance representa a fronteira de suas orientações estéticas e formais. Dele em diante é que o autor alagoano vai diferir de tudo que se produziu nos anos de 1930, embora relacionado a essa geração de escritores.

Graciliano Ramos estava com um pé de um lado da fronteira literária que o definiria de um modo, e com outro noutro lado do front. Não tendo decidido ainda o rumo que tomaria, vai deixar marcado na estrutura de São Bernardo exatamente o problema que Lafetá preparava-se para enfrentar: o de entender como Graciliano articulou as propostas de vanguarda e o neorrealismo. Não foi à toa que Antonio Candido disse que São Bernardo "ocupa um lugar à parte na literatura”. E o estudo destes dois críticos foi fundamental para nossa tese.

\footnotetext{
${ }^{118}$ Ibidem, pp. 31 e 32.

119 “Ora vejam! Se eu possuísse metade da instrução de Madalena, encoivarava isso brincando.” Cf. p. 10. Também termo extraído do modo de produção dos engenhos de açúcar; de "coivara", processo de queimadas a fim de limpar o terreno e de fertilização do solo.
} 


\section{Fronteiras e limites de São Bernardo}

Um dos caminhos mais comuns percorridos nos estudos do estilo, da técnica e das obras de Graciliano Ramos, foi, e é até hoje, o da avaliação da produção escrita realizada em sua totalidade. São poucos os trabalhos detidos em um determinado momento da carreira do autor de Vidas Secas ou que delimitaram por gêneros específicos o percurso do artista, a fim de um estudo mais rigoroso do fenômeno literário que caracteriza a produção de Graciliano.

Resulta dessa força uma das maiores bibliografias, cuja crítica biográfica predomina, dando a seu autor status justíssimo de mestre; mas que, por outro lado, contribuiu para as generalizações e análises muito breves - por isso, superficiais - de uma produção bastante particular, pautada pelo trabalho delicado dos detalhes, pelo talhe fino, demorado e paciente das minúcias, que não se pode apreender e compreender através de passadas largas e rápidas pinceladas com que se satisfaz essa tendência crítica de avaliar o todo em tão poucas linhas, sem debruçar-se no fato concreto da produção em suas condições históricas e materiais de possibilidade.

É fato também - mesmo para aqueles que tiveram a preocupação de definirem bem o seu objeto de estudo, o momento e o lugar de suas empreitadas - não ser tarefa das mais tranquilas desviar os olhos dos lotes literários que se avizinham, insinuando-se férteis, tão próximos estão daquele sítio em que se intentou arregaçar as mangas. E é esta uma das seduções e riscos ao se trabalhar com um dos aspectos ou uma das obras de Graciliano: não há enormes distâncias aparentemente entre uma e outra desse ponto de vista mais abrangente, seja na produção das crônicas, dos contos ou dos romances; e, principalmente, não há entre Infância e Memórias do Cárcere, contrastando com as demais produções, muitas diferenças, como, por exemplo, a proximidade aparente à produção ficcional do autor. Assim, ao nos debruçarmos sobre a leitura da crítica, inevitavelmente ocorre a unificação da obra pela construção de sua autoria a posteriori.

Só ao arremeter-se dessas alturas se percebem as distâncias entre uma e outra e a necessidade de melhor organizar as ideias e fatos ocultados por esse viés de análise crítica muito a gosto ainda hoje. Talvez os projetos de pós-graduação venham corrigir e melhor organizar essa monumental bibliografia de estudos literários, constituída ao longo da recepção crítica a respeito do principal romancista da década de 30. De qualquer modo, é esta uma das tarefas dos estudos científicos atualmente: a constituição de campos de pesquisa integrados uns aos outros a fim de desembaraçar os emaranhados históricos produzidos por 
essa crítica generalizante que conserva a pacificidade das dessemelhanças sob os selos da história literária ou dos nomes construídos ao longo da recepção.

A imagem que se nos apresenta ao olhar tão abundante volume de estudos não esconde a redução. Quando verificado mais de perto, o volume esvai-se, vai-se reduzindo sob o efeito das redundâncias e repetições, tornando a leitura dessa bibliografia uma verdadeira jornada, muito provavelmente abandonada a certa altura por parecer que tudo que tinha de ser dito sobre a obra já o fôra. Ledo engano. Dissipados os nevoeiros da repetição (o muito enfático "mesmo" leva à desconfiança), abrem-se enormes lacunas e percebe-se o muito ainda do que se dar conta do que foi e do que é esse estilo, essa técnica, esse monumento artístico literário cunhado com o nome "Graciliano Ramos". ${ }^{120}$

Foi com isso que nos deparamos ao reconstruir a recepção de São Bernardo: embora aparentemente o autor de Caetés fosse o mesmo de São Bernardo, no sentido estanque do estilo e do nome, não o são segundo o dinamismo das produções; mas se tornam pelo efeito da sucessão histórica da recepção, inviabilizando a análise ou mesmo interferindo, de modo geral, na forma de apreender cada uma das obras em função de etiquetas lá pregadas que dirigem a experiência crítica, com um arsenal teórico pronto e prescritivo, em detrimento do fazer artístico e de suas condições históricas de produção.

As fronteiras que separam Caetés (1933) e São Bernardo (1934) - vizinhos tão próximos na publicação, dado que uns poucos meses os separam ${ }^{121}$, e distantes quanto à recepção crítica, assim como em termos de estilo, processos técnicos e temáticos - são algo ainda por se explicar. O primeiro romance foi tido desde a década de sua publicação como "exercício literário" que dá origem ao segundo romance sob o efeito de "evolução salutar", nas palavras de Dias da Costa, que veremos mais à frente neste capítulo. Uma das consequências desse modo de perceber a literatura é a de reduzir a importância do primeiro romance, subordinando-o às características do segundo e apagando as fronteiras técnicas de cada produção.

\footnotetext{
${ }^{120} \mathrm{O}$ registro da recepção ocorrido com Graciliano é um pouco parecido com o que Hansen, estudando a obra poética de Gregório de Matos, vai se confrontar: "A autoria (...) é produzida pela unificação que se torna produtiva a posteriori: 'Gregório de Matos' é uma etiqueta ou um dispositivo discursivo, unidade imaginária e cambiante nos discursos que o compõem contraditoriamente numa hierarquia estética determinada pela 'cadeia de recepções', na expressão de Jauss. Não-substancial, é efeito ou produto da leitura dos poemas atribuídos, não sua causa ou origem." HANSEN, João Adolfo. A Sátira e o Engenho: Gregório de Matos e a Bahia do século XVII / São Paulo: Ateliê Editorial; Campinas: Editora da Unicamp, 2004. (Cf. p. 31 ou o capítulo "Um nome por fazer")

121 "A publicação de Caetés precedeu de apenas poucos meses a de São Bernardo e logo toda crítica e público compreenderam a importância do novo escritor (...)" AMADO, Jorge. "Mestre Graça" In: RAMOS, Graciliano. Viagens / Rio de Janeiro; São Paulo: Ed. Record, 2002. (Cf. p. 7)
} 
Sabemos todos que Caetés foi escrito entre 1926 e 1927, no município alagoano de Palmeira dos Índios, quando o seu autor frisava pelos 34 anos de idade. Até 1930, ele o foi aprimorando lentamente, dando-lhe aos poucos a sua arte final. Do ponto de vista histórico, é, pois, um romance dos anos 20, que enfrentou as dificuldades e vicissitudes do acesso à acolhida editorial, e cujo lançamento, na realidade tardio, se deveu a um episódio pitoresco do conhecimento geral: os famosos relatórios de Graciliano Ramos como prefeito daquele município. ${ }^{122}$

Como se disse, uma questão assim demanda mais que a simples filiação desse romance aos anos 20, e não faremos isso aqui: é preciso sim notar que dos 34 anos para 42 as transformações podem ter sido bastante significativas. Neste mesmo artigo, Lêdo Ivo confere a Caetés um tipo de estrutura e característica estética muito diferente daquela a que já nos acostumamos a entender vinculado ao Regionalismo em termos de história da literatura. Ligando-o a uma tradição de produção do final do século XIX e começo do XX, para Lêdo Ivo, o romance estaria inserido num tempo histórico e cronológico literário do qual foi deslocado pela publicação tardia.

De certo modo, ele não está errado: o diálogo imediato deste romance não previa a mesma audiência que São Bernardo, mas que neste último interferiu e interfere ainda hoje, segundo o pressuposto de vínculos, primeiro com Eça de Queiroz e depois com Machado de Assis, o que trouxe um prejuízo à segunda obra e a sua autoria: Graciliano é visto como um autor moderno do século passado. O problema é que o autor de Caetés, segundo Lêdo Ivo,

(...) deve ser incluído na linhagem dos ficcionistas que, como Lima Barreto, Monteiro Lobato de Urupês (1919) e o esquecido Godofredo Rangel de Vida Ociosa (1920), transitam pelo espaço literário que vai da morte de Machado de Assis, em 1908, até a publicação de Menino de Engenho, de José Lins do Rego, em 1932, este, cronológica e esteticamente, o primeiro e fulgente marco da renovação literária que deflagrou a modernidade do nosso romance. (IVO, 1984: p. 37)

É curioso como até hoje esse detalhe tenha perdurado. E não foi algo ocultado por Graciliano: "Publiquei-o oito anos depois de escrito, por insistência de Augusto Frederico Schmidt, que tinha virado editor." ${ }^{, 123}$ E tal informação o empurra para mais distante ainda das datas fornecidas por Lêdo Ivo: em vez de produzido entre 1926 e 1927, foi de fato escrito entre 1924 e 1925, dois anos após os acontecimentos da Semana, o que faria de Caetés, filiado que está à segunda fase do Modernismo, o dito Regionalismo, um dos primeiros romances modernistas em sua segunda fase (!), ao lado de Memórias Sentimentais de João Miramar, de 1924, se esse critério fosse válido:

Em perspectiva atual, a expressão Pré-Modernismo [assim como Modernismo segunda fase] deveria ser abolida do vocabulário crítico, pois, além de incaracterística, pressupõem que o período

\footnotetext{
${ }^{122}$ IVO, Lêdo. Um estranho no ninho: a propósito do cinquentenário de Caetés de Graciliano Ramos In: Revista Colóquio Letras, n. ${ }^{\circ}$ 77. Portugal, p. 35, 1984. Fonte: http://coloquio.gulbenkian.pt/index.html

${ }^{123}$ Cf. em "Alguns tipos sem importância" In: RAMOS, Graciliano. Linhas Tortas / Rio de Janeiro: Record; São Paulo: Martins, 1975.
} 
imediatamente anterior [ou posterior] ao movimento de 22 só possui interesse na medida em que antecipa uma etapa de maior importância histórica e de mais relevo artístico. (...) Em literatura, essa visão faz supor que só se deve estudar o passado como antecipação legitimadora do momento em que se produz o enunciado crítico. ${ }^{124}$

Ainda que os eventos posteriores só tivessem importância na medida em que derivassem do movimento modernista, é claro que Caetés, por mais que o tema do canibalismo esteja nas entrelinhas do romance, não é modernista, menos ainda pelo fato de ter sido escrito dois ou três anos depois da Semana de 22. Mas também não é Regionalista por ter sido publicado em 33, tampouco porque São Bernardo tenha sido publicado logo depois. A história dessa primeira publicação de Caetés está envolta a muito nevoeiro. O próprio José Lins do Rego, escrevendo sobre o romance, vai tentar incluí-lo à força nas turbulências políticas e ideológicas dos anos 30, invertendo o sentido do que nele se apresenta:

O livro de Graciliano Ramos trouxe ao Brasil que se descobre e acorda a contribuição de um mundo que cae aos pedaços. Não ha nada que sirva ali: tudo é mesquinho, nem um homem nem uma mulher a olhar para cima, a estremecer de felicidade. E o peor é que tudo aquillo é verdade crúa e certa. E ainda querem affirmar que no Brasil só os proletarios soffrem o peso da vida. Estes brasileiros do Cahetés teem direito tambem á revolução. ${ }^{125}$

Ao se ter desenvolvido, nesse romance, os conflitos de um herói burguês segundo as concepções estéticas do romance de 20 e não segundo as novas orientações estéticas do ponto de vista do proletário - cujo interesse nesse período vai levá-lo a protagonizar em praticamente tudo que se faz nessa década em termos de romance -, José Lins interpreta o romance de Graciliano como "denúncia da mediocridade" da vida da classe média. O que torna o próprio romance bastante medíocre. E isso, na realidade, já é um forte indício do horizonte de expectativas do público desse decênio, suposto público evidentemente, interferindo de modo direto na produção artística. O que diz José Lins sobre Caetés é basicamente o mesmo que diz Oswald de Andrade a respeito de Serafim Ponte Grande, publicado no mesmo ano em que Caetés, também escrito fora do período: "Publico-o em seu texto integral, terminado em 1928. Necrológio da Burguesia. Epitáfio do que eu fui." 126

Em suma, como tendência literária do passado (impressionante como apenas cinco anos se passaram), tanto o Realismo como o Modernismo já não eram mais produções vistas como desvinculadas de uma ideologia elitista e burguesa. Daí Oswald apresentar Serafim

\footnotetext{
${ }^{124}$ TEIXEIRA, Ivan. "Policarpo Quaresma como caricatura de uma idéia de Brasil" In: BARRETO, Lima. Triste Fim de Policarpo Quaresma / São Paulo: Ateliê Editorial, 2001. (Cf. pp. 14 e 15)

${ }^{125}$ LINS DO REGO, 05/02/1934

${ }^{126}$ ANDRADE, Oswald. Serafim Ponte Grande / São Paulo: Círculo do Livro S.A., (s.d.). (Cf. p. 11)
} 
Ponte Grande ao público de 30 a partir da mesma ideia que José Lins tem de Caetés: "de denúncia de um modo de vida e de um padrão” burguês de literatura.

Em 1935, Jorge Amado publica no Boletim de Ariel “'São Bernardo’ e a Política Literária"; o romancista baiano fornece os mesmos dados cronológicos, através de um depoimento meio cochichado, com mão em concha ao pé do ouvido, dizendo o seguinte:

\footnotetext{
O Schmidt é um velho inimigo do Graciliano. Inimigo gratuito. Já com o primeiro livro do Graciliano o Schmidt pintou o diabo. Prendeu o livro quatro annos na sua casa editora. O livro sahiu quando estava velho e não agradava mais o Graciliano. $\mathrm{O}$ poeta pretendia fazer o mesmo com o $S$. Bernardo. ${ }^{127}$
}

Este seria, para Jorge Amado, um dos motivos de Graciliano ter publicado São Bernardo pela Ariel, e o que teria levado Schmidt a escrever de modo depreciativo seu artigo sobre São Bernardo, o primeiro a respeito do surgimento do segundo romance de Graciliano. E é sabido que é no mesmo período de publicação de Caetés que o escritor alagoano está debruçando-se sobre as finalizações de São Bernardo; por isso, talvez, ele tenha mencionado na crônica "Uns tipos sem importância" que só publicara aquele romance por insistência de Schmidt: de fato, já não o agradava mais, tamanha era a distância entre o que realizara entre 1924 e 25 para o que vinha já arrematando em 33.

Além do mais, tendo escrito naquele período, o público esperado não correspondia às mesmas expectativas do público leitor dos anos 30, o que o levou a uma empreitada de alterações nos originais de Caetés que, ao lermos as correspondências de Graciliano datadas entre 1930 e 1932 publicadas em Cartas, não ocorreram na realidade: embora não saibamos os motivos, o certo é que algum acidente ocorrera com esse manuscrito modificado (tenha ele caído no mar, lago ou rio ou sido danificado porque Schmidt saíra com ele debaixo de chuva; seja qual for o motivo, o certo é que diz Graciliano: “(...) Escrevi a ele rompendo todos os negócios e pedindo a devolução duma cópia que tenho lá. (...) o Schmidt teve razão e fez-me um favor." ${ }^{128}$ Portanto o Caetés publicado é o mesmo que foi escrito entre 1924 e 25.

Muito provavelmente Graciliano seja um desses escritores em cujo processo pessoal de desenvolvimento estético, formal e estilístico se distinga por dois momentos de produção literária. Apenas um trabalho detido, compenetrado, sobre a questão cronológica de sua obra e a análise séria dos pormenores, passo a passo, de sua projeção artística segundo práticas

\footnotetext{
${ }^{127}$ AMADO, fevereiro de 1935.

${ }^{128}$ RAMOS, Graciliano. Cartas / Rio de Janeiro: Ed. Record, 1992. (Cf. p. 130)
} 
históricas de produção literária pode dar-nos uma melhor perspectiva do valor de sua obra num todo de forma mais convincente. ${ }^{129}$

Pensemos, por exemplo, que os famosos relatórios manifestem já um caráter de transição que vai se dar em São Bernardo de modo definitivo: aí teríamos, portanto, um divisor de águas, cujos anos de 1928 e 29 seriam um marco geral de prática literária coincidindo, muito apropriadamente, com a prática particular de elaboração artística do autor alagoano a partir de São Bernardo em diante. Considerando o momento da prática (1928 e 29) em prosa, não o que a designação Modernismo/Segunda fase ou Regionalismo induz a pensar segundo a História da Literatura, é aí que surge A Bagaceira de José Américo de Almeida, assim como Mário de Andrade publica Macunaíma e Oswald de Andrade constrói Serafim Ponte Grande - embora este último só tenha sido publicado em 33.

É ainda nesse mesmo período, no ano de 1929, que vai ser publicado Sob o Olhar Malicioso dos Trópicos de Barreto Filho, pouco conhecido hoje, mas que exerceu enorme influência sobre a crítica de então. Esse romance apresenta particularidades que não têm nenhuma relação com o dito Regionalismo, o que talvez o tenha lançado fora do cânone pelo efeito, segundo o mesmo problema apontado por Ivan Teixeira nos estudos literários de modo geral, da perspectiva finalista teleológica da história da literatura. Esse romance, juntamente com Macunaíma, Serafim Ponte Grande e A Bagaceira, entre outros, apresentaria ainda outra tendência provável de realização literária. O que supõe uma enorme diversidade de possibilidades da prática naquele momento convivendo e dando dinamicidade ao que vai se tornar propriamente característico nos anos 30: "Aí está, em grande medida, o significado de Sob o Olhar Malicioso dos Trópicos: ser a concretização de um desejo, ainda que difuso, de construir alguma coisa de próprio em nossa cultura e em nossa literatura." (BUENO, 2006: p. 100)

Isto é, os resultados da proposta de 22 só vão começar a surgir, em prosa, nesse momento e em convívio com outras possibilidades que não foram discutidas na Semana, portanto, que ainda não participavam de um sistema literário realizado (conforme as concepções de Antonio Candido na Formação: autor/obra/público). Daí Caetés não ter

\footnotetext{
${ }^{129}$ Fernando Alves Cristóvão refuta a ideia de que o aparecimento de capítulos-contos na imprensa tenha dado origem à elaboração de obras a posteriori, nesse caso, artifíciosas e desmontáveis como Vidas Secas: "Formulam a hipótese de compilação, iludidos por informações deficientes das datas de redação dos originais e seu aparecimento na imprensa periódica, pelo que tomam contos-capítulos como alheios a uma elaboração unificadora que se lhes afigura posterior e artificiosa." CRISTÓVÃO, Fernando Alves. Graciliano Ramos: Estruturas de Valores de Um Modo de Narrar / 2ª . ed., Rio de Janeiro: Editora Brasília/Rio, 1977. (Cf. p. 94). Isto é, a impressão geral é que a unidade da obra existe a partir de determinada data, não de um processo anterior a ela. O mesmo se daria com Caetés, por não se levar em conta a hipótese de elaboração anterior da publicação.
} 
nenhum vínculo com o movimento vanguardista tampouco com o romance de 30, despertando a sensação de que fosse "exercício de um iniciante". Todo o valor da obra, suborndinada a um período literário a que não pertence, perde seu valor intrínseco e subordina os romances posteriores a um ponto de vista inadequado.

Dentre os primeiros críticos que escreveram sobre São Bernardo em 1934 e 35, Dias da Costa foi um dos que compreenderam as transformações que vinham ocorrendo na nebulosa vida literária brasileira e melhor fixou o que se passava então:

A leitura do romance S. Bernardo do sr. Graciliano Ramos, veiu amenizar a decepção que me produziu a leitura do romance $O$ Boqueirão do sr. José Americo de Almeida.

Ha muito tempo já eu lera A Bagaceira. E, embora achasse nesse livro os typos um tanto falsos, considerando aquelle Lucio um specimen bastante exotico da fauna humana, maculando com conceitos wildeanos a brancura das paredes da casa do engenho paterno e possuido por um amor incompreensivel que o leva ás raias da imbecilidade, culpava de tudo isso a época em que o livro foi escripto e admirava no autor o Messias de uma nova cruzada para a humanização do romance brasileiro, o iniciador de uma estrada que tão brilhantemente foi trilhada depois, principalmente pelos escriptores do Norte. Agora, porém, depois de já publicados João Miguel, de Rachel de Queiroz, Menino de Engenho, de José Lins do Rego, Cacau, de Jorge Amado, Os Corumbas, de Armando Fontes, etc., a leitura de um romance como $O$ Boqueirão é um salto tão violento para traz que chega a produzir um mal-estar só explicavel com o conto de João do Rio, A sensação do Passado.

E' o que não succede com S. Bernardo.

De Cahetés, primeiro livro do sr. Graciliano Ramos, optimo livro, embora um tanto antiquado, para o novo romance, ha uma evolução salutar, um aperfeiçoamento de techinica, uma segurança na dosagem de emoção que chega ás vezes ao irreprehensivel. ${ }^{130}$

Certamente Dias da Costa começa a perceber, nos princípios da década de 30, as diferenças cruciais entre os horizontes de expectativas do que chamamos hoje PréModernismo - ainda preso ao lastro do Realismo/Naturalismo e de tendências positivistas - e o Modernismo praticado como marco de uma produção consubstanciada pelas reivindicações estéticas do movimento moderno, ajustadas às necessidades do próprio decênio: "a língua oral", componente puramente estético anteriormente, também vai ser o elemento que vai dar um maior grau de humanidade às obras. Muito embora num tom de desprezo (principalmente pelo aspecto pitoresco que se propõe a figura do homem comum até então estereotipado pela linguagem e por uma consciência limitada), Dias da Costa foi quem melhor delineou a questão:

José Américo (...) Concebe arbitrariamente os seu typos, constroe-os physicamente ao seu modo, dálhes as suas proprias idéas, liga-lhes os cordéis de fantoches, e, assim equipados, bota-os no livro e começa a mexer os dedos para que elles se movam de accordo com sua vontade, emquanto elle banca o ventriloco. E o resultado não póde ser outro. Os bonecos começam a dar saltos grotescos, a falar em linguagem de Ruy Barbosa, a se abraçar com caminhões que transportam materiaes de obras contra a secca e a emittir conceitos nietzcheanos, embora estejam em pleno sertão do Brasil, "sob o olhar malicioso dos tropicos". 
Tudo vae muito bem quando o leitor é myope. Mas quando não o é e percebe os cordéis e conhece que aquellas palavras correctas vêm dos bastidores, tem a impressão de que está sendo logrado e que, julgando comprar um romance, adquiriu apenas um bilhete para um espetaculo de marionettes. ${ }^{131}$

Notemos que essas considerações, alusões e pareceres ocorrem pelo surgimento de São Bernardo; isto é, para Dias da Costa, Graciliano havia se estabelecido por um paradigma novo de romance, de qual nem mesmo Caetés participaria. Não apenas pela oposição relativa a concepções estrangeiras manipulando o caráter do brasileiro, ou pela caracterização da norma culta segundo a linguagem de Rui Barbosa, mas pelo fato de que o apagamento destas características, no segundo romance de Graciliano, permitiu a adequação das personagens a uma nova perspectiva literária, privilegiando concepções e costumes, humanizando-as pela quebra do estereótipo, mas, sobretudo, por retirar das mãos dos heróis burgueses as iniciativas de transformação e possibilidade de mudanças sociais, econômicas e políticas. A ditadura do proletário começa a ter aí forte influência.

Caetés, além de não apresentar tais características, afasta-se completamente do regional: é mais uma descrição dum drama pequeno-burguês cotidiano que nem mesmo traz como elemento conflituoso a herança rural que permeia quase todo romance de 30. Em São Bernardo os costumes locais e os valores da cidade permeiam as ações dos personagens e se manifestam como herança simbólica contraditória, constituída historicamente, o que lhes dá um sentido de vida muito próximo do que se supunha na realidade.

Todos elles, devido aos factores que os cercam e os elementos formadores das suas personalidades, fariam cá fóra, num ambiente semelhante, as mesmas coisas que fazem no livro. Sómente uma coisa Paulo Honorio seria incapaz de fazer na vida. Era escrever, como escreve, o seu proprio romance. ${ }^{132}$

Ora, Dias da Costa, neste ponto - embora tendo tido a perspicácia de estabelecer as diferenças entre o que já era do conhecimento e expectativas do público com as novidades marcantes do novo romance de Graciliano -, não poderia deixar de prescindir de algumas noções reinantes no horizonte de expectativa do seu tempo e de qual nenhum crítico escapou: se compararmos o autor fictício de São Bernardo com qualquer outro dessa categoria, o efeito de inverossimilhança impor-se-á peremptoriamente. Basta pô-lo ombro a ombro com João Valério, Bento Santiago ou Brás Cubas, Gonçalo Ramires, o "homem do subterrâneo", e o resultado não será outro:

Pelo modo de tratar o assumpto, S. Bernardo recorda vagamente o Le noeud de Vinéres, de Fraçois Muriac. Neste romance é o proprio personagem tambem o autor de sua historia mas em fórma de confissão. Ahi, porém, trata-se de um velho advogado, com inclinações longinquas pela literatura, e

\footnotetext{
131 Idem.

${ }^{132}$ Ibidem.
} 
com uma série de problemas interiores a resolver, dotado de outra complexidade na sua aspereza e com outras tonalidades tragicas no seu egoismo, que o Paulo Honorio, de S. Bernardo não tem. ${ }^{133}$

Esse aspecto da construção do personagem-autor vai se repetir até perder-se o fôlego durante os anos de 1930 e 40 (Álvaro Lins refere-se a isso quando diz a respeito desse mesmo problema do romance como algo que já vinha sendo dito insistentemente): e o que ele tem, como bem observa Schmidt, é um problema de filiação literária (evidentemente o que nesse período é um erro). A inadequação dele reflete a inadequação das categorias de análise e dos modelos de comparação de que se lançou mão, que o filia a um sistema de obras que o não comporta: se não havia muita dificuldade para relacionar, por exemplo, João Valério a Gonçalo Mendes Ramires, o mesmo já não vai ocorrer pacificamente ao se relacionar o narrador de São Bernardo a qualquer outro tipo de "autor fictício" provindo desse filão literário. A inovação de Graciliano marca uma ruptura clara com tudo que se fazia nesse sentido.

Paulo Honório narrador não provém dessa "família de autores fictícios", por isso não pode se adequar ao romance produzido anteriormente: a inovação levou-o a fazer ajustes técnicos e formais, por consequência, que vão deixar de ser avaliados pela subordinação do ponto de vista à verossimilhança externa a ele: a construção das cenas, o caráter atípico da temporalidade, o uso dos recursos discursivos etc., entre tantos detalhes, ou desaparecem ou são adequados ao ponto de vista. E o narrador, autor fictício de São Bernardo, não tem, até onde sabemos, congêneres na literatura do século XIX, tampouco na literatura do princípio do século XX, o que levou Abel Barros Baptista a formular a hipótese curiosa de que Paulo Honório, talvez, fosse o primeiro proprietário rural da história literária a recorrer aos serviços de um ghost writer. ${ }^{134}$

Essa subordinação ao romance realista do século XIX impede a análise dos pormenores da obra, contaminando-os. É bastante provável que os dois primeiros capítulos de São Bernardo representassem, por antecipação, o problema a ser enfrentado: se no capítulo 1 o romance (livro) está subordinado ao valor simbólico, em circulação nas trocas verbais, determinado por práticas já consagradas, subordinando o processo de construção ao produto final, o capítulo 2 inverte essa organização: com a falência do projeto do capítulo 1 , o produto final fica indeterminado, indeterminando o processo que dará origem a um novo produto. Este último, por ser uma hipótese futura, não determinada pelo valor simbólico encerrado nas trocas, leva a pôr em perspectiva o processo como mais importante do que o

\footnotetext{
${ }^{133}$ SCHMIDT, 16/12/1934.

${ }^{134}$ BAPTSTA, 1993: p. 166.
} 
produto final. O processo, portanto, anterior ao pensar, para que se adequasse às perspectivas do crítico, foi suprimido ou visto do ponto de vista da personalidade brutal do protagonista, o que teria a ver mais com a técnica e a percepção humana sob o efeito da modernização do mundo, da mecanização da força do trabalho e com a velocidade do tempo moderno etc. transformam-se, sob a perspectiva psicologizante do romance do século XIX, em violência de um herói-problemático isolado do qual resultaria uma técnica literária.

Esse produto final, portanto, não tem mais nenhum vínculo com o que se estabeleceu como posterior, o futuro do livro; só pode ser avaliado pelo que foi produzido, não segundo seu próprio processo material de existência histórica. Olhar para o passado a fim de capturar esse processo impede que São Bernardo seja avaliado pelo que provavelmente só viria a ter vínculo com ele mesmo no futuro. Mas isso, até onde sabemos, jamais aconteceu. O próprio Riobaldo, de Grande Sertão: Veredas, talvez o mais próximo dos narradores a Paulo Honório, só tem uma linguagem própria segundo o narratário-escritor, o doutor, indivíduo da cidade, quem escuta sua narrativa e, no mínimo, se não realiza a escrita, a legitima do ângulo de visão da urbanidade.

Talvez, se comparássemos a cadela Baleia com o cãozinho Quincas Borba do romance de Machado de Assis, o efeito não fosse diferente. Isso se não houvesse nenhuma novidade em Graciliano. Por que Baleia goza de autonomia de pensamento? Por que Quincas Borba só tem olhos que significam algo muito vagamente a Rubião e segundo a perspectiva do narrador? Enquanto os de Baleia nos mostram, de sua perspectiva, um Fabiano enorme etc., os de Quincas Borba apenas olham seu protetor? O que passa pela cabeça de Rubião poderia ser o mesmo que se passa na consciência de Quincas Borba. Mas só temos acesso às suspeitas de Rubião a partir do processo de discurso indireto livre. O motivo de que a comparação não seja possível é por esse recurso técnico sofrer uma modificação e não revelar mais os processos psicológicos de personagens nem o domínio do foco narrativo como o fator produtor de maior grau de realidade. É que tanto o narrador de Vidas Secas como Baleia filiam-se a uma expectativa de verossimilhança, atrelada a um período da história da literatura, enquanto prática, completamente oposta ao que marca o século XIX.

De outro modo, por que o estranhamento ocorrido com Paulo Honório, como autor fictício, não ocorrera com Baleia nem com o narrador de Vidas Secas? Ninguém acusou Graciliano de ter construído uma personagem impossível; nenhum estranhamento ocorreu pelo fato de aquela cadelinha ter imaginação tão complexa, esperanças e expectativas tão humanas. Embora o processo de projeção da imaginação de Baleia seja aparentemente o 
mesmo usado pelo narrador de Quincas Borba, o discurso indireto livre, a diferença é que, a partir desse processo, o que penetramos como consciência, no romance de Machado, só pode ser atribuído a Rubião, que o narrador conscientemente manipula a fim de revelar a tolice de que o filósofo do humanitismo poderia ter-se incorporado no cãozinho a fim de vigiá-lo quanto ao uso da herança.

Em Vidas Secas, como percebeu Letícia Malard, é bastante perigoso atribuir as consciências, aparentemente projetadas pelo recurso de discurso indireto livre, ou ao narrador, exclusivamente, ou aos personagens. As fronteiras que demarcavam claramente os limites desse recurso, hieraquizando o ponto de vista no passado, desaparecem no romance moderno porque a técnica não seria mais a mesma nem o modo de percepção do mundo. Baleia torna-se importante na medida em que é projeção de uma humanidade, independentemente de não ser humana, e revela um modo de ver particular do século XX, o que seria impossível no século anterior em função do darwinismo e do positivismo.

Assim como Baleia está limitada para verbalizar seu pensamento, também Paulo Honório está limitado para escrever ostensivamente a sua história, não impedido de estabelecer um plano de superação do problema. Em hipótese alguma está ele, absolutamente, limitado de pensar que pode escrever e de realizá-lo (se este fosse o objetivo de Graciliano). Tivesse ele escrito alguma coisa, nos moldes dos autores fictícios anteriores, aí então se poderia dizer que Graciliano fracassara, pelo motivo de que, do modo como o situou naquele momento, isso seria, de fato, impossível.

O fato de não termos nenhuma manifestação de defesa pessoal por parte do escritor alagoano à sua obra nos dá certeza de que a construção de seu personagem fora efetivamente consciente e cumpria o desígnio de trazer à tona as contradições evocadas por reivindicações ingênuas, apenas possíveis no campo do imaginário, não das realizações. Sendo possível apurar esse detalhe, não através da crônica "Uns Tipos sem Importância", mas sim em "Justificação de Voto", em que, defendendo determinada escolha, oferece seu parecer crítico favorável a uma obra literária que todos julgaram "falhada" num concurso literário. Não conhecemos o texto a que se refere Graciliano. Mas a situação técnica e formal dele é de todo semelhante a São Bernardo:

D. Iaiá é matuta, honesta, duma honestidade rigorosa e de pedra. O sr. José Carlos Borges [autor avaliado no concurso] compreende-lhe a moral e a dureza. E fixa-as em cartas que D. Iaiá faria se soubesse escrever. Se ele nos exibisse os bilhetes dessa criatura, com a sua ortografia e a sua pontuação, a história seria horrorosa. A redação não é da velha, mas parece-nos que é. A correspondência tem, portanto, verossimilhança, uma verossimilhança obtida à custa de repetições oportunas e dum vocabulário pequeno (...) (RAMOS, 1975: pp.150 e 151) 
Esse ponto é crucial. É sobre um tipo novo de verossimilhança que ele pondera. Um tipo de verossimilhança que não toma como referência ao contexto social ou empírico, isto é, a realidade física, sociológica, naturalista ou mesmo o sistema formal aristotélico ou informal do registro da língua; é o sistema de referências do próprio texto convertido em ficção que produziria a verossimilhança ou inventaria uma língua falada, que deixaria de ser registro do uso para ser "literatura". Assim a ilusão de "língua falada" é produzida pelas próprias regras da norma culta. Não há em São Bernardo um parágrafo fora do registro da norma: o que temos lá é uma ficção da língua oral. Só assim a "língua oral” poderia ser convertida em componente estético, elemento literário, uma nova e genuína expressão, como diz Rosenthal, literária.

Disso talvez provenham as explicações para o que constatou Raul Lima, em 1967, a respeito das eliminações feitas por Graciliano na terceira edição de São Bernardo: elas são todas de natureza gramatical, não lexical, cuja supressão aproxima a língua escrita da linguagem oral em nível suprassegmental.

\begin{abstract}
No capítulo VII, no período "Seu Ribeiro, que era justo, procurava o matador, amarrava-o e levava-o para a cadeia da cidade", Graciliano substituiu a conjuntiva "e" depois de "amarrava-o", pela vírgula (...) Outra modificação (...) foi a supressão do artigo indefinido "uma" nas seguintes frases: "Seu Ribeiro tinha uma família pequena e uma casa grande" e "Como havia agora uma liberdade excessiva, a autoridade dele foi minguando até desaparecer". (...) retirou o "que" inicial de "Que loucura estar uma pessoa ao mesmo tempo zangada e tranqüila!" O "que" e ponto de exclamação. Nada mais. ${ }^{135}$
\end{abstract}

A supressão desses elementos aproxima sintaticamente esses períodos à tonalidade da língua oral ou mesmo de uma sintaxe do próprio "pensar". A Sociolinguística tem oferecido bastantes trabalhos esclarecedores das diferenças entre a linguagem escrita e oral nesse sentido. Em São Bernardo a supressão de partículas subordinativas e de conectivos gera sintaticamente orações coordenadas. Aproximando-as da fala, são elas que produzem o tom, a sensação de língua falada. De tal modo que muitos críticos chegaram a falar que

(...) só se explica o caso crendo-se que os modernos literatos do Brasil acham originalidade digna de ser incluida em um volume que vai passar por centenas de mãos, concorrer para a formação de uma literatura - qualquer frase imbecil pronunciada por um matuto boçal e analfabeto. ${ }^{136}$

E vai ser só após os anos de 1950 que as referências fictícias do texto de Graciliano vão começar a ser encaradas desse modo. O topos dominante, antes disso, vai ser o de "humanização", segundo a ilusão de língua falada, conforme um padrão nacional, que daria aos personagens uma vida genuinamente verdadeira e brasileira. Por esse motivo também,

${ }^{135}$ LIMA, Raul. "Sobre Graciliano Ramos" In: BRAYNER, Sônia (org.) Graciliano Ramos, Coleção Fortuna Crítica / Rio de Janeiro: Civilização Brasileira, 1978. (Cf. pp. 134 e 135)

${ }^{136}$ MARTINS, Franz. 06/03/1935 
ainda que não haja saída para a inverossimilhança de Paulo Honório enquanto autor, é este o valor determinante da obra então.

Só este fato já faz de São Bernardo um caso único de "ambiguidade" em nossa história: a vantagem de Paulo Honório poder ser visto como um ser humano, não um puro e simples artifício, impediu-o de cair não só em total desgraça, nesse período, como no esquecimento. O que torna seu autor um emblema, um enigma. Ambiguidade que, inclusive, fixa-lhe uma personalidade antimodernista sem que o seja. O que vemos foi que ele, se por um lado, ao apropriar-se das propostas modernistas, foi julgado, segundo os mesmos critérios modernizantes, antimoderno; por outro, ao adequá-las às expectativas do público de 1930, não anulou o significado simbólico puramente estético que elas representavam na década anterior: a aceitação também se dá pelo fato de que a arte é artifício, não mimese fotográfica. Vejamos a seguir. 


\section{O manifesto da prática}

Finalmente, se o projeto estético de 22 ocorrera nos teatros, conferências e manifestos, segundo as condições próprias do movimento dentro desse período, a década seguinte vai inaugurar, conforme suas próprias condições histórica, política e ideológica, em meio à expansão da imprensa escrita e da indústria livreira, o debate em forma de prática literária simultaneamente ao processo de produção: à medida que ela vai se oferecendo ao público é que seus ideais surgem no contexto literário. Não houve, como em 22, um manifesto sequer, o que fez a crítica ocupar a imprensa, de modo geral, e discutir a produção conforme as contradições manifestadas nas relações diversas que manteve com o movimento vanguardista.

Dessa maneira [de modo geral], o romance de 30 se define mesmo a partir do modernismo e certamente não poderia ter tido a abrangência que teve sem as condições que o modernismo conquistou para o ambiente literário e intelectual do país. No entanto, ao afastar-se da utopia modernista, terminou por ganhar contornos próprios que, de certa forma, só seriam retomados pela ficção brasileira do pós-64, também dominada pelo desencanto. ${ }^{137}$

Uma das conquistas do movimento de 22 resultou numa espécie de democratização do fazer crítica e fazer literatura pouco comum antes do decênio de 30: há um crescente de novos nomes, para muitos de nós completamente desconhecidos, não só fazendo a crítica como produzindo suas obras, de modo que a maioria deles manifestasse, em relação à produção dos outros, o que muita vez estava praticando. É o caso de Graciliano, por exemplo. O que talvez, por ter se manifestado, ainda que não definidamente no princípio dos anos 30 , segundo características e atitudes antimodernas, provocou aparentemente a ilusão de estar desvinculado do Modernismo.

Embora, de fato, os escritos deixados por Graciliano tenham esse caráter de combate às vanguardas, a produção a desmente. E há ainda o problema de suas crônicas, publicadas em Linhas Tortas - com exceção de "O Romance de Jorge Amado" datada de 17 de janeiro de 1935 -, serem todas escritas a partir de 1937, o que nos leva a pensar que muito pouca coisa dita pelo autor ou tenha sentido duplo, ambíguo, quando defrontado à prática que levou a cabo, ou ainda era algo a se definir, a se nomear, e que, sem que soubesse exatamente, participava daquele universo ideal de modernização segundo o critério de humanização da literatura que domina a década.

\footnotetext{
${ }^{137}$ BUENO, Luís. Uma História do Romance de 30 / São Paulo: Edusp; Campinas: Ed. da Unicamp, 2006. (Cf, p. 80)
} 
E a crítica, de certo modo, revela a contradição ao caracterizar as atitudes práticas do autor alagoano, em termos negativos ou positivos para o período, revelavando outro lado do autor. O artigo de Schmidt é o carro-chefe de boa parte da problematização levantada ao longo dos anos 30 sobre o segundo romance de Graciliano. E a "inverossimilhança" do narrador Paulo Honório, como autor de romance, praticamente dominou o debate, fazendo que aflorasse dele certas relações literárias com quais se mostrava claramente incompatível.

O que parecia ter surgido nos anos 40 com Álvaro Lins, retomado por Rui Mourão no final dos anos 60 e, numa das últimas tentativas de se resolver o conflito, abordado nos anos 90 por Abel Barros Baptista, marca o romance desde seu surgimento. Schmidt, ao apontar a "inverossimilhança" do narrador, em dezembro de 1934, provocou nos ânimos de escritores e críticos verdadeira rejeição sobre seu próprio estilo; não injustificável se observarmos os termos de que lança mão em seu artigo, manifestando pouca reverência ao autor de Caetés.

\begin{abstract}
Mas, essa discordancia do processo do livro do sr. Graciliano Ramos, não lhe diminue, ao meu ver, a importancia. Trata-se realmente de um livro de um escriptor, prejudicado de raro em raro, por uma especie de cacoête de fazer humour. ${ }^{138}$
\end{abstract}

Acentuando a inverossimilhança como uma falha produzida pelo cacoete de fazer humor, Schmidt desperta um fabuloso coro de vaias sobre si mesmo, sobre seu estilo, manifestadas, voluntariamente ou não, como elogio ao estilo "sem flores" de Graciliano. Vejamos o que diz Olivio Montenegro.

Agora, onde não ha duvida, me parece, é que a arte não é uma copia da vida, não tem uma funcção meramente passiva de espelho. (...)

Se a tendencia para associar os outros ás nossas convicções não fosse tão traiçoeira ao nosso amor proprio, eu diria que o sr. Graciliano Ramos quando escreveu "S. Bernardo", o fez com a plena consciencia de que a arte não é uma lacaia da vida. E escrevendo um romance de cor regional elle não insiste na exposição de detalhes, na "cor local”, para o premeditado effeito do pitoresco. Não faz do seu romance um bric-á-brac de phrases e coloridos para todo o gosto. ${ }^{139}$

Ao opor-se a certo estilo, a certa concepção de valor literário, de finalidade da representação, o crítico é obrigado a recorrer a critérios de valor claramente "antirregionais", contrário ao romance de costumes e, sobretudo, sob a orientação das concepções modernas de literatura. Observe-se também o que diz Octavio Tarquínio de Sousa.

Nenhum livro é menos "roman-fleuve" que "S. Bernardo". Nessas duzentas e dezoito paginas seccas, estrictas, concentradas, o sr. Graciliano Ramos poz apenas o essencial. Grande inimigo do superfluo,

\footnotetext{
${ }^{138}$ SCHMIDT, 16/12/1934

${ }^{139}$ MONTENEGRO, 25/01/1935
} 
do derramado, em "S. Bernardo" não ha nada inutil, não ha tempo perdido. Nenhuma paizagem para enfeitar, nenhum quadro que pudesse ser dispensado. ${ }^{140}$

Isto é, o projeto estético, pictórico ou idílico dos trópicos não era tão concernente à realidade humana quanto parecia, o que a revelava tão artificial quanto árida no sentido de representação humana inumana, apresentando uma sensibilidade que não provinha senão da literatura e de uma prática literária que desprezava as condições reais daqueles que idilicamente eram representados nela:

Os autores atuais foram estudar o subúrbio, a fábrica, o engenho, a prisão da roça, o colégio do professor cambembe. (...) Ouviram gritos, pragas, palavrões, e meteram tudo nos livros que escreveram. Podiam ter mudado os gritos em suspiros, as pragas em orações. Podiam, mas acharam melhor pôr os pontos nos ii. (RAMOS, 1975: p. 93)

Eis aí, conforme dissemos, como Graciliano constrói Madalena. Ela não é a heroína dele. "O jardim, as flores, as almas simples do homem do campo", que conferem a ela não só uma determinada leveza como a caracterizavam em termos de convenção, eram facilmente reconhecido nesse período. Tanto que Oscar Mendes vai dizer que ela é inumana. E sua atitude de proletarização era uma crítica de Graciliano a essa literatura que transformava seus heróis burgueses em proletários sem os compreender. Tanto que a polêmica ganha matizes semelhantes com o artigo de Carlos Lacerda na Revista Academica:

\begin{abstract}
Os homens têm esbarrado constantemente num dilema excessivamente literario, por isso artificioso: trabalho braçal, brutalidade - trabalho intelectual, sensibilidade.

No entanto já deviamos todos saber que o dilema é outro, que não se espreme nessa estreitesa, e vê mais longe: do lado dos exploradores, embotamento da sensibilidade - do lado dos explorados, expansão dessa sensibilidade.

Bem sabemos que um camponês ou um estivador possúem uma reserva inesgotavel de instinto ainda não afinado no diapasão das conveniencias. Conhecemos academicos, literatos enriquecidos que se perdem em nevoeiros de falsa sensibilidade $(. . .)^{141}$
\end{abstract}

Ora, percebemos claramente que a polêmica gerada pela ideia de "inverossimilhança", associada à falta de leveza e de suspiros poéticos, passa a atingir em cheio as convenções literárias. Quando Lacerda diz que se tem esbarrado num dilema literário é porque a correspondência literária com a referência sociológica, agora, está posta em dúvida. Donde vem a sensibilidade literária de "um Paulo Honório" senão do artifício da construção? E esse artifício, concebido pelos modernistas, foi capaz de revelar o artifício do caráter inumano da literatura vinculada ao século XIX, assim como sua matriz ideológica. Talvez convenha dizer que o Modernismo não teria o sentido que tem na atualidade sem essa

\footnotetext{
${ }^{140}$ TARQUÍNIO DE SOUSA, 17/12/1935

${ }^{141}$ LACERDA, 01/1935 (Fonte: Fundação Casa de Rui Barbosa; os textos citados anteriormente encontram-se no Acervo Graciliano Ramos do Instituto de Estudos Brasileiros da USP)
} 
literatura produzida nos anos 30. O suposto abandono do caráter estético moderno por parte dos autores desse decênio se daria exatamente pelo fato de que a ênfase da literatura passara a ser político-ideológica. Mas o que há, de fato, é que essa estética tinha o mesmo fundo, apenas não era percebida como passa a ser, a ponto de Oswald interferir em seu próprio texto tentando conduzir o público que o receberia a ver em Serafim Ponte Grande o caráter panfletário daquele modo de vida fanfarrão - isto é, como um valor do mundo burguês.

Aliás, quando Graciliano fala, em 1935, de uma literatura que nos dias de chuva fica trancada em casa, bem agasalhada, e que quando sai leva guarda-chuva e capa de borracha, não há como não pensar no começo de Serafim Ponte Grande:

A paisagem dessa capital apodrece. Apareço ao leitor. Pelotari. Personagem através de uma vidraça. De capa de borracha e galochas. Foram alguns militares que transformaram a minha vida. Glória dos batizados! Lá fora, quando secar a chuva, haverá o sol. ${ }^{142}$

Graciliano refere-se a esta obra do mesmo modo como Oswald se referiu a ela: "Necrológio da burguesia". O caráter burguês da estética moderna, assim como o do romance do final do XIX e princípios do XX, fica evidenciado em 30; e que, por ter estabelecido um tipo específico de "autor-fictício" (todos são invariavelmente letrados, duma sensibilidade tal, conforme um tipo específico de educação e acúmulo de capital cultural), o campo da experimentação narratológica fechou-se para qualquer possibilidade de dar voz ao outro de modo geral e de que era necessário agora tratar ostensivamente. O proletariado vai expropriar as regiões do foco narrativo na literatura. E o grande dilema será, como apontou Dias da Costa, escapar das ciladas que ele produz, como as caracterizações pitorescas do homem comum a partir de uma linguagem correta, ou da simplificação desse homem a partir da reprodução de sua linguagem em uso. Sendo produto do mundo burguês, o romance já era um modo burguês de ver o mundo. A única saída era vê-lo como artifício.

Graciliano, tendo buscado parte de sua "matéria-prima" na fonte da cultura popular, não poderia deixar de rever as noções de homem do povo. E Paulo Honório é esse homem do povo (o contrário do paradigma da convenção "alma simples do homem do campo" apresentado por Gondim a fim de seduzir Madalena). O que causou não só estranhamento, mas também muito embaraço: “Temos aí um retrato em corpo inteiro de um senhor de fazenda do nordeste, rudimentar e analfabeto, porém com um sentido de propriedade e de classe pouco comum." 143 Paulo Honório estaria em condições de classe isolado do universo burguês, ao mesmo tempo em que, pela sua relação com a propriedade, a ele também ligado.

\footnotetext{
${ }^{142}$ ANDRADE, Oswald. Serafim Ponte Grande / São Paulo: Círculo do Livro S.A., (s.d.). (Cf. p. 15)

143 AMADO, Jorge. 05/1935
} 
Isso Oscar Mendes, crítico católico de Minas Gerais, vai usar contra o ideal socialista, dizendo que os piores patrões geralmente têm origem proletária, o que talvez tenha sido um dos motivos de Graciliano tantas vezes, nas cartas escritas a Heloísa, se referir a ele e que estava lhe escrevendo uma resposta. E a relação que Graciliano faz com a crítica de Oscar Mendes é a seguinte: "Creio que o meu pai e minha mãe me fizeram lendo o Alencar, que é o que havia no tempo deles.” (RAMOS, 1992: p. 146)

Isto é, a proletarização de Paulo Honório por parte do crítico era uma romantização de São Bernardo. Quando ele, nessa carta, datada de 3 de abril de 1935, começa perguntando a Heloísa se não há gado zebu no último capítulo, quer sugerir exatamente isto: Paulo Honório não é um proletário. E, como vimos nas análises dos primeiros capítulos, as orientações de Paulo Honório seguem um padrão de relação social antiquíssimo, situado nos primórdios de nossa colonização e da instauração aqui dos tribunais de justiça, com o fim de que as leis impostas pela coroa portuguesa fossem guardadas. Conforme os estudos de Stuart Schwartz, sucedeu-se que, assim como os magistrados não possuíam reservas de capital como os colonos (fazendeiros), estes últimos não possuíam o status dos juízes. Por isso estabeleceuse aqui uma relação de influências com o poder caracterizado pela aliança familiar: os nomes de cada família - como os do avô de Luís da Silva, o velho Trajano Pereira de Aquino Cavalcante e Silva, em Angústia - incorporavam-se uns aos outros, numa relação de aliança do poder judiciário com os fazendeiros, formando seus clãs, o que permanece no século XX. Paulo Honório reproduz, em sua trajetória, a tentativa de restabelecer essa mesma rede de relação social, o que revela sua mentalidade. Ele não é, portanto, facilmente compreendido a partir de categorias românticas, segundo uma filosofia liberal, tampouco segundo os padrões éticos e morais da sociedade burguesa.

Em termos de crítica aos aspectos idealizantes do romance modernista, a pergunta foi como converter em literatura aqueles princípios de investigação histórica de nossas origens sem idealizar suas fontes ou modificá-las, sem permitir que elas se ajustassem ao universo de dominação ideológica. Não há dúvidas de que Graciliano foi à fonte vanguardista a fim de solucionar o problema. O que diz Olívio Montenegro é o mesmo que Lafetá diz a respeito das propostas de Mário de Andrade:

(...) a arte é diferente da natureza; o movimento lírico, nascendo dos impulsos profundos do inconsciente, tende a criar algo muito afastado do "natural"; destrói-se o conceito de mimese direta (fotográfica) e chega-se à conclusão de que a beleza da arte é uma construção artificial. (LAFETÁ, 2000: pp. 162 e 163) 
Se este foi um problema colocado pelo movimento modernista em termos teóricos ou poéticos, São Bernardo o coloca na própria prática, não como "impulsos profundos do inconsciente", mas como um processo de labor paciente e detido na busca de novos paradigmas. Os impulsos profundos do inconsciente propostos por Mário de Andrade no Prefácio Interessantíssimo foram explorados por Graciliano pela construção de Paulo Honório, divergindo dele apenas quanto ao processo de inspiração.

Jorge Amado, em maio de 35, descreve Paulo Honório radicalmente como analfabeto; quer dizer, é sabidamente implícita a ideia de que não se estava diante de um narrador típico, que escreve sua história, embora nenhuma tentativa de explicar esse novo processo de ficcionalização tenha sido realizada, o que supõe mais sua dimensão política e ideológica do que estética e literária. Principalmente porque Jorge Amado respondia diretamente, com esse artigo, a Schmidt.

Vale repetir: é nesse sentido que entendemos a polêmica gerada desde o artigo de Schmidt. Interpretada de um modo e de outro, conforme a concepção de arte de cada um que escreveu sobre São Bernardo naqueles primeiros anos, a inverossimilhança do narrador atinge sempre os limites entre a ficção e a literatura e entre a realidade e o como ela é construída.

Liberdade completa ninguém desfruta: começamos oprimidos pela sintaxe e acabamos às voltas com a Delegacia de Ordem Política e Social, mas, nos estreitos limites a que nos coagem a gramática e a lei, ainda nos podemos mexer. (RAMOS, s.d: vol. 1, p. 34)

Essa característica de construção não passa despercebida em 34. Agrippino Grieco, discorrendo em linguagem um tanto empolada, comenta a incidência do romance sobre si mesmo como crítica, ou quase ensaio crítico sobre romance e sobre os romancistas literalmente:

Enxerga-se aqui o mundo em quadrinhos literarios e os homens surgem sempre em funcção de figuras de livro. Quasi se chega a concluir que no sr. Graciliano Ramos, acima de um ficcionista, ha um grande ensaista, um grande intellectual, antes destinado a criticar os creadores que a crear por conta própria. Seu tinteiro apparece sempre, sua caixa de titeres está muito á mostra. ${ }^{144}$

Nesse sentido, a problematização da literatura, na arte de romancear de Graciliano, problematiza o mundo simultaneamente; isto é, o autor de Vidas Secas foi capaz de fazer convergir o projeto estético com o ideológico. Dizer que Graciliano deixava de "criar por conta própria" significou naquele primeiro momento que o seu "arsenal" literário não provinha de si mesmo. E um dos aspectos que nos dá essa convicção é a comparação das primeiras manifestações conservadoras em relação às vanguardas. Tomemos, por exemplo,

${ }^{144}$ GRIECO, 30/12/34 
alguns trechos do polêmico artigo de Monteiro Lobato, de 20 de dezembro de 1917, no jornal O Estado de São Paulo, ao tratar da exposição de Anita Malfatti:

Há duas espécies de artistas. Uma composta dos que vêem normalmente as coisas e em conseqüência disso fazem arte pura (...) A outra espécie é formada pelos que vêem anormalmente a natureza, e interpretam-na à luz de teorias efêmeras, sob sugestão estrábicas de escolas rebeldes, surgidas cá e lá como furúnculos da cultura excessiva. (...) brilham um instante, as mais das vezes com a luz do escândalo, e somem-se logo nas trevas do esquecimento. (...) [Anita Malfatti] seduzida pelas teorias do que ela chama arte moderna, penetrou nos domínios dum impressionismo discutibilíssimo e põe todo o seu talento a serviço de uma nova espécie de caricatura. (...) $)^{145}$

É de conhecimento de todos nós que esse episódio foi "comemorado" emblematicamente pela crítica como o marco do movimento vanguardista nos anos de 1920, pondo em lados opostos "os passadistas" e a modernidade. Antonio Candido, por exemplo, diz que a produção modernista, de modo mais geral,

(...) nos anos 20 tinham um caráter excepcional, restrito e contundente próprio das vanguardas, ferindo de modo cru os hábitos estabelecidos. Nos anos 30 houve sob este aspecto uma perda de auréola do Modernismo, proporcional à sua relativa incorporação aos hábitos artísticos e literários. ${ }^{146}$

Isto é, os princípios modernos incorporados aos hábitos literários dos escritores, nos anos 30, não feriam mais de modo cru e contundente os padrões e hábitos estabelecidos, como no caso de Malfatti e Monteiro Lobato. Ora, mas após mais de 20 anos da famosa polêmica em que vão se envolver os primeiros modernistas, indo à testa de defesa de Malfatti Oswald de Andrade -, vemos registrado, quase que nos mesmos termos de Lobato, as mesmas considerações a respeito de São Bernardo:

Seduzidos por um principio falso de independência mental, tomam por espontaneidade o que não passa de desleixo, estimam no erro deliberado uma manifestação de audacia e crêm que haja expressão revolucionaria em attitudes que, ás vezes, enojam, mas quasi sempre apenas enfaram o bom senso de letrados e não letrados. (...)

Em "S. Bernardo" ha substancia de um bello romance, capaz de impressionar pelos motivos humanos e pela força de ambiente. Lastima-se que o autor tenha dispensado a essa materia prima outro brio intellectual, imprimindo-lhe a unidade plastica e a energia de expressão que devidamente a consolidassem numa estructura legitima, resistente, duravel. ${ }^{147}$

São muitas as passagens encontradas em cujo parecer crítico manifesta-se repúdio violento à inovação estética, técnica, e que não tem apenas relação ao uso de expressões hoje sem efeito qualquer sobre o leitor. Tal constatação nos revela em que medida Graciliano ligava-se a princípios vanguardistas, rompendo completamente com o estilo inscrito em

\footnotetext{
${ }^{145}$ BRITO, Mário da Silva. História do Modernismo Brasileiro: antecedentes da Semana de Arte Moderna / Rio de Janeiro: Civilização Brasileira, 1997. (Cf. p. 47 e 48) O artigo de Lobato pode ser conferido no trabalho de Brito na íntegra.

${ }^{146}$ CANDIDO, Antonio. "A Revolução de 30 e a Cultura" In: A Educação pela Noite e Outros Ensaios / São Paulo: Ed. Ática S.A, 1989. (Cf. p. 185)

${ }^{147}$ G.P. 10/01/1935 (Pseudônimo ainda não identificado).
} 
Caetés e ao mesmo tempo ligando-o à dita segunda fase: ao passo que havia "substância de um belo romance, capaz de impressionar pelos motivos humanos". E é o que se verifica nessas primeiras manifestações da recepção: de um lado, uma forma que desagrada aos homens de "gosto", produzida pela ilusão de "língua oral", e, ao mesmo tempo, agrada pela impressão de um realismo vivíssimo; de outro, o contrário: aos que aderiram já ao modernismo em termos de ideal popular literário, desagrada o fato de Graciliano não ter dado maior destaque à vida miserável dos trabalhadores do eito, que não tenha deixado de lado os aspectos claramente românticos da literatura:

A tragedia intima entre Paulo Honorio e a mulher, as ciumadas riduculas e o temperamento abrutalhado do marido, absorveram completamente os homens do eito, a vida do campo, a exploração feudal do fazendeiro, tudo emfim que se relacionasse com a lucta economica, com a miseria humana, com o desconforto dos pobres diabos que levavam braço no pé do ouvido quando a revolta apparecia nos labios. Como succedeu no caso do Marcolino. ${ }^{148}$

A manifestação desses juízos críticos ou, pelo menos, vários critérios de valor e de fruição da obra responde exatamente ao fato de que, num mesmo texto, duma mesma estrutura, os elementos literários articulados produziram efeitos diversos conforme o horizonte de expectativas de sua audiência, evidenciando-se, portanto, qual a importância da revisão histórica da recepção de São Bernardo, seu lugar exato, de que modo sua estrutura articula-se pelos sistemas de sentido e normas de interpretação, produzindo determinados efeitos ainda hoje sensíveis.

Esperamos ter sido possível demonstrar os fatores histórico-literários, aqui, que impedem a compreensão dessa obra como moderna genuinamente; cujos esteios com o passado apenas participam de sua estrutura sugestivamente, não literal, o que produziu uma crítica nada unívoca. O que poderá ser lido a seguir na íntegra encerra-se no elogio do repúdio e, contraditoriamente, o repúdio no elogio, porque São Bernardo certamente dialogou, de imediato, com um tempo confuso, ainda cheio de incertezas quanto ao futuro tanto do país como da própria literatura.

Por esse motivo, os efeitos de contradição do romance, de incoerência, de paradoxo, de desencontro, de construção destrutiva e destruição construtiva não podem ser encarados como problema. Todas essas tentativas de leitura do romance revelam nele o convívio do outro no mesmo, como diria Bakhtin, em termos de dialogismo, e que são próprias da luta histórica de nossa cultura na tentativa de harmonizar as disparidades de nossa constituição

\footnotetext{
148 JUREMA, 12/1935. Obs.: é possível que o personagem Marciano tivesse, no original, o nome de "Marcolino": Aderbal Jurema talvez tenha esquecido de corrigir esse detalhe após a publicação do romance, já que ele confessa ter lido o original.
} 
social: na nossa galeria de "cavaleiros medievais", ao lado de Macunaíma, nosso herói sem caráter, e de Peri caberia, por que não, mais um de nossos antepassados: Paulo Honório, "sonhando com atoleiros e a figura medonha de um lobisomem".

Finalmente chegamos à última etapa de nossos esforços de compreensão da importância desse romance. A seguir, faremos uma pequena contextualização histórica dos artigos coletados ao longo da pesquisa a fim melhor situá-los no solo de sua aparição. 


\title{
5. Critérios de transcrição dos textos e contextualização
}

\begin{abstract}
Julgo que aqui neste quarto, sozinho, vou ficando safado. Têm-me aparecido idéias vermelhas. Anteontem abrequei a Germana num canto de parede e sapequei-lhe um beliscão retorcido na popa da bunda. Não tem importância. Isto passa. Vai sair uma obra prima em língua de sertanejo (...)
\end{abstract} (RAMOS, 1992: p. 125)

Pouco tempo após a publicação de São Bernardo em 1934, vem a lume os primeiros artigos e textos sobre as impressões deixadas pelo segundo romance de Graciliano Ramos. Data de 16 de dezembro de 1934 o primeiro artigo, escrito pelo poeta Augusto Frederico Schmidt no Diário de Notícias do Rio de Janeiro - muito embora Aderbal Jurema, em Boletim de Ariel, naquele mesmo dezembro, confesse ter lido o romance no original, fato que não nos impede de pesar que, também, tenha escrito seu artigo antes mesmo de o romance ser publicado.

O texto de Aderbal Jurema não tem data completa, e ficamos sem saber como encaixá-lo, cronologicamente, entre as publicações de dezembro: data do dia 30 de dezembro o texto de Agrippino Grieco, "Um Romance”, publicado no Diário de Pernambuco. E ainda, em 24 de dezembro, o de Lúcia Miguel Pereira.

Por conta disso, alguns critérios foram adotados a fim de estabelecer uma ordem adequada, tanto para os primeiros artigos quanto para os subsequentes. O primeiro foi o do dia da publicação, seguido do mês (na falta do dia) e, consecutivamente, do ano. Em casos como o de dezembro de 1934, apostamos na hipótese de que o texto de Aderbal Jurema tenha sido publicado entre os dias 16 e 30, muito embora pudesse ter saído em 31, véspera de AnoNovo ou mesmo logo após o dia 12, quando surge a primeira propaganda publicitária do romance encontrada no Instituto de Estudos Brasileiros da USP (IEB).

Quanto a normas de transcrição, optou-se não fazer qualquer alteração nos textos: estão transcritos tal como impressos. Contudo, dados os aspectos filológicos, isso não significou a adoção dos critérios da edição crítica; apenas são feitos apontamentos em notas de rodapé, quando necessárias, em função de passagens complicadas por falta de sinalização, erros tipográficos ou pela adoção de normas gramaticais, no mesmo texto, indicando variantes e variáveis, adotadas segundo critérios da cada veículo de imprensa independentemente de um padrão geral.

Nesse sentido, nos preocupamos em notificar apenas e em alguns momentos mais específicos, por exemplo, quando um trecho transcrito foi extraído de nota marginal: nos textos coletados do acervo do IEB, as indicações de fonte e de seus respectivos autores, 
quando não indicadas no próprio corpo do artigo impresso, estão escritos a próprio punho por Graciliano $^{149}$. Não tivemos, no IEB, contato integral com a página do jornal, já que os textos foram recortados e colados em folhas avulsas ${ }^{150}$. Já em relação aos textos da Revista Academica, por não se tratar de recortes, mas da revista na íntegra, foi possível ter uma ideia mais abrangente do caráter específico de sua representatividade dentro de seu ambiente histórico. Daí nosso entendimento sobre a abrangência e posição política e ideológica dos órgãos de imprensa de onde os artigos foram tirados, baseados no contexto das obras consultadas e que delas tratam em seus estudos.

Outro aspecto que nos cabe dar esclarecimento refere-se à seleção dos artigos transcritos. Devido ao grande volume de textos, optamos primeiramente por aqueles que datam de 33 a 38, sobretudo por ser o período em que se escreve sob as impressões deixadas pela primeira edição do romance. Outro motivo foi o surgimento de Angústia em fins de 1936, e a impressão da segunda edição de São Bernardo em 1938, abrindo um novo veio de abordagem crítica. A transcrição também valeu à pena pelo fato de a crítica escrita e publicada, mais amplamente conhecida, ter surgido apenas a partir do fim da década de 1940 .

Dentro deste recorte temporal, portanto, apenas os textos referentes à crítica literária foram transcritos: são numerosas as notas publicitárias, neste ínterim, que não revelam nenhum efeito de leitura, muito embora não sejam desprezíveis as enfáticas relações entre a literatura de Graciliano com as de Machado e de Eça ou a suposta orientação ideológica do autor alagoano. O importante sobre essas notas publicitárias é que elas cruzaram o país, de Curitiba (não as encontramos em jornais do Rio Grande dos Sul), passando pelos grandes centros do Sudeste, ao Estado do Pará. Isto inclusive levou um dos desafetos de Jorge Amado a comentar na edição da Revista Academica que homenageava Angústia pelo Prêmio Lima Barreto: "considero como solução fundamental para o prestigio da obra de Graciliano Ramos, a publicidade constante em torno dos seus livros." ${ }^{151}$ Informa-nos, ainda, sobre a primeira tradução de São Bernardo para a língua estrangeira, que ocorreu ou no ano anterior, 1936, ou em 1937 mesmo: diferentemente do que pensávamos até hoje, a primeira edição do romance

\footnotetext{
${ }^{149}$ Parece que em alguns artigos sobre Caetés, por terem sido coletados pelo próprio romancista, segundo nos indica a caligrafia das notas marginais, Graciliano fez alguns apontamentos relativo a normas ortográficas, acentuando palavras ou inserindo vírgulas, até mesmo corrigindo a concordância. Optamos por deixá-las de lado, visto não haver nesse detalhe relevância em relação ao tipo de estudo empreendido aqui.

${ }^{150}$ Estes documentos encontram-se no Instituto de Estudos Brasileiros da Universidade de São Paulo; "Arquivo Graciliano Ramos. Série: Recortes. Subsérie: Fortuna Crítica / Pastas 3 e 5. IEB/USP". Os demais, publicados na Revista Academica do Rio de Janeiro, encontram-se na Fundação Casa de Rui Barbosa, Botafogo, Rio de Janeiro.

${ }^{151}$ COUTO FERRAZ, Aydano. 05/1937.
} 
fora do Brasil ocorre na Argentina, com o título de Feudo Bárbaro, e a ela o crítico relaciona não só à publicidade como também eventos que por lá se deram na ocasião.

Deixamos também de transcrever notas e artigos sem nenhuma referência e cuja fonte autoral fora negligenciada (sobretudo por não sabermos quando foi realmente publicados, o que poderia prejudicar a compreensão do recorte temporal escolhido pela pesquisa); contudo não entendemos do mesmo modo o uso dos pseudônimos, compreendendo este recurso não como forma de escamotear-se, mas como opção estilística do período, bem como de um artigo publicado no jornal $O$ Estado de São Paulo, cuja autoria não foi encontrada em função de que o recorte da matéria excluiu a primeira parte por tratar-se de outro assunto.

Assim, pautamo-nos por estes critérios baseados ainda no tempo limite de uma dissertação de mestrado, deixando de explorar um material ainda bem mais vasto, talvez, do que pode supor o corpus dessa pesquisa. O tempo médio de nossa pesquisa levou-nos a abandonar certas empreitadas mais densas: quando estivemos na Biblioteca Nacional do Rio de Janeiro e lá buscamos as fontes completas dos recortes encontrados no IEB, nos demos conta das dificuldades de uma apuração mais profunda da contextualização histórica dos artigos e de ainda encontrarmos os que talvez não tivessem sido coletados pelo autor Graciliano e familiares, doados ao Instituto por Heloísa Ramos em 1980.

São estas as observações mais importantes quanto ao corpus constituído de 1933 a 38 para este trabalho. Esperamos que ele não só elucide o leitor a respeito de nossa pesquisa como possa vir a ser explorado de outras maneiras e perspectivas.

Quanto ao momento histórico da aparição desses artigos, é importante ter em mente, em primeiro lugar, que tanto a crítica quanto o romance são publicados num dos mais conturbados momentos da década de 1930, cujo evento de maior importância e que iria decidir o caráter do governo de Getúlio Vargas, instaurado com a Revolução de 30, foi a Intentona Comunista deflagrada em novembro de 1935 no Rio Grande do Norte; que provocaria em Recife a sublevação de algumas cidades-satélites juntamente com parte do Exército. A Intentona ainda viria a implicar na sublevação de quartéis importantes do Rio de Janeiro e, embora o evento no Norte tenha sido mais ou menos involuntário, a responsabilidade destes incidentes vai ser assumida por Luis Carlos Prestes, acendendo o pavio de suspeitas imaginárias quanto a um possível domínio da União Soviética em nosso território. Todos sabem que Graciliano foi encarcerado nessa época. Mas ainda não houve nenhum estudo mais aprofundado dos motivos que o levara à prisão. 
Convém compreender este fato histórico, cuja fagulha vai disparar o gatilho que deu origem ao Estado Novo tal como nós o conhecemos hoje. Muito do que se pensa sobre o governo Vargas é comumente mal compreendido por estenderem-se retroativamente a períodos em que não existiam as mesmas características que vieram a lhe dar as feições que teve a partir de 1936, quando todos os seus programas se desenvolvem e são divulgados ostensivamente na imprensa.

Antes disso, o Estado Revolucionário que pôs abaixo as transições do governo do país entre São Paulo e Minas Gerais, além de não ter um programa formal administrativo nem político, não tinha nenhum adversário à sua altura senão o desafio de atender o clamor geral sobre as necessidades imediatas do país e que se baseavam exatamente na insatisfação com o atraso em relação aos países mais avançados no sistema capitalista. Tais necessidades apresentavam-se mais ou menos como Benedicto Heloiz Nascimento nos conta em seu estudo desse período:

\begin{abstract}
Era preciso intervir nas atividades econômicas, de educação e meios de comunicação, a fim de silenciar o canto de sereia das multinacionais e interesses estrangeiros prejudiciais ao país. Era necessário cuidar da saúde pública e amparar o trabalhador, sensibilizando-se frente às suas necessidades como ser humano e cidadão. O Governo teria de ser dedicado à promoção da riqueza brasileira, ao mesmo tempo que de todas as regiões e populações do país. Ele teria que proteger o mercado e promover a cultura e o homem brasileiros. ${ }^{152}$
\end{abstract}

Após as crises econômica de 1929 e política de 1930, intensificam-se os debates a respeito de nosso atraso econômico, político e social. A literatura parecia encampada na denúncia do estado praticamente feudal do interior, revelando um Brasil quase desconhecido nos ambientes urbanos. Graciliano, em 17 de fevereiro de 1935, escreve o artigo, já citado aqui, sobre Suor de Jorge Amado, publicado um ano antes, e nos põe cientes, com muita clareza, do clima: "Os escritores atuais foram estudar o subúrbio, a fábrica, o engenho, a prisão da roça, o colégio do professor cambembe. Para isso resignaram-se a abandonar o asfalto e o café." (RAMOS, 1975: p. 93)

A linguagem com que constroem suas narrativas, lastreada nas proposições dos modernistas, é trabalhada com o fim de humanizar a literatura, mas ao mesmo tempo como forma de ataque permanente aos intelectuais, acusados de escrever sobre um mundo praticamente fantasmagórico: "Há uma literatura antipática e insincera que só usa expressões

\footnotetext{
152 NASCIMENTO, Benedicto Heloiz. A Ordem Nacionalista Brasileira: o nacionalismo como política de desenvolvimento durante o Governo Vargas / São Paulo: Humanitas/FFLCH/USP: Instituto de Estudos Brasileiros/USP, 2002. (Cf. p. 17)
} 
corretas, só se ocupa de coisas agradáveis", diz Graciliano no começo desse artigo. E que Suor mostra o ódio do pobre inspirado pelos ricos.

Ocorre, contudo, que esses escritores que arregaçaram as mangas, foram à questão do problema e "Ouviram pragas, palavrões, e meteram tudo nos livros que escreveram" ${ }^{153}$, logo seriam interpretados sob forte influência do espectral comunismo, cuja estratégia era a de destruir as bases de sustentação da "alma" do povo brasileiro, atingindo "Deus, pátria e família". Era evidente que essa atitude, do uso de uma linguagem considerada bárbara, da inclusão das cenas lascivas nos livros, tinha como função “(...) estabelecer uma posição firme diante dos críticos da direita, em geral católicos que condenavam o uso do palavrão ou a inclusão de qualquer tipo de cena de sexo, por imorais." 154

O fato é que essa atitude, até certo ponto, independia da posição política do escritor e de suas opções ideológicas. Mas logo isso deixou de ser encarado apenas como uma forma de "ferir de modo cru e contundente os hábitos estabelecidos", como diria Antonio Candido em relação às vanguardas, para ser encarada como atitude conspiratória.

Como vimos na epígrafe deste capítulo, Graciliano caracteriza o surgimento da ideia do episódio de Paulo Honório e Germana como "vermelha", dizendo depois "Isso passa. Vai sair uma obra prima em língua de sertanejo (...)". Isto é, tratava-se apenas de uma caracterização literária, mas que já tinha absorvido a oposição às tendências de direita e se cristalizado em atitude de "destruição da família" sob a influência do comunismo. Nesse mesmo ano de 1932, em que Graciliano se debruçava na construção de São Bernardo, a ameaça comunista passa a ser farejada em todos os setores da vida social brasileira; para as elites ela cheirava a pólvora. Autoridades políticas e religiosas alertavam a necessidade de combate aos ideais revolucionários inclusive com as mesmas armas com que eles vinham conquistando seus adeptos.

Político conservador de São Paulo, Macedo Soares era antigo presidente da Associação Comercial na capital paulista; (...) Começou sua carreira diplomática em 1932, quando Vargas e Melo Franco lhe pediram para chefiar a delegação brasileira à conferência sobre desarmamento em Genebra. Durante sua estada na Europa, fez uma viagem a Roma, onde teve uma audiência particular com Pio XI, ouvindo dele sobre a necessidade de uma ação mais vigorosa contra o comunismo no Brasil. (...) Disse que competia às autoridades brasileiras realizar uma censura mais ativa das publicações jornais, livros e folhetos - destinados ao povo; e que cabia às classes conservadoras do país realizar a contrapropaganda também por meio da imprensa, conferências, livros, folhetos, etc. ${ }^{155}$

\footnotetext{
${ }^{153}$ Idem. p. 93

${ }^{154}$ BUENO, 2006: p. 165

${ }^{155}$ HILTON, Stanley Eon. A Rebelião Vermelha / Rio de Janeiro: Record, 1986. (Cf. pp. 43 e 44)
} 
E a sugestão de sua santidade vai ser levada às últimas consequências: “(...) Odette Carvalho e Souza, (...) sob a tutela de Macedo Soares, (...) redigiu um memorando intitulado 'Os Soviets e a America latina' (...)”, em que, comparando o caráter dos russos ao nosso, menciona que a estratégia bolchevista seria a de “(...) dissolução das nossas instituições e das nossas leis, e destruir os sentimentos de 'Deus, Pátria e Família', tão fortemente arraigados à alma do nosso povo"156. Por isso a interpretação de personagens como Madalena, Padilha e padre Silvestre naquele momento denota diretamente o que Paulo Honório verbaliza em alto e bom tom: "Comunista!"; "tentando afastar os empregados sérios do bom caminho"; "Mulher sem religião é capaz de tudo"; "Uma nação sem Deus! bradava padre Silvestre", comentando como se deu a Revolução de Outubro: "Fuzilaram os padres" (...) E os soldados, bêbados, espatifavam os santos e dançavam em cima dos altares". "Espatifaram nada! interveio Padilha. Isso é propaganda contra-revolucionária”.

Diferente do modo como interpretamos hoje o capítulo 24, na primeira metade dos anos 30 ele revela o clima de um mundo atormentado pelos efeitos da crise econômica de 29, que havia feito desmoronar completamente o pequeno surto de desenvolvimento econômico e industrial ocorrido nos anos 20. A quebra, por exemplo, do dínamo do descaroçador de algodão em São Bernardo ou o volante emperrado de uma máquina revelavam esse efeito da crise porque se ligavam diretamente à economia norte-americana: "A grande penetração de capital de risco estrangeiro no incipiente setor industrial brasileiro, a partir da Primeira Guerra Mundial, trouxe um aumento da dependência econômica, tecnológica e cultural." (NASCIMENTO, 2002: p. 124)

Após a crise, os setores de bem de consumo, como o do vestuário (setor algodoeiro), inundaram o mercado interno e foram se acentuando: "Portanto era natural que as importações dos gêneros fabricados pelas indústrias tradicionais [como a têxtil] tendessem a ser decrescentes" ${ }^{\prime 157}$. Os desgastes do maquinário eram naturais. Conta-nos Nascimento que na década de 20 inclusive os industriários desse setor pediram a proibição de importação de maquinário, o que foi atendido em 1931, levando ao emprego dobrado da mão de obra e de seus turnos, "desgastando as máquinas e ferramentas de maneira excessiva e predatória" 158 .

As consequências, na ficção de São Bernardo, desse efeito, observado no ambiente histórico, é um dos primeiros problemas com que Madalena se depara no descaroçador.

\footnotetext{
${ }^{156}$ Idem, pp. 47 e 48.

${ }^{157}$ Idem, p. 126

${ }^{158}$ Ibidem, p. 128
} 
Evidentemente ela não compreende nada disso, apenas diz ao marido que a família de mestre Caetano está passando fome.

O sentimento geral do período é o de uma certeza de que não é possível ao intelectual ficar de fora, apenas observando os acontecimentos. Afinal, todo um mundo ruiu e é preciso construir outro, melhor e mais justo. O grande problema, evidentemente, é como fazer isso. (BUENO, 2006: p. 105)

As agitações política, greves, o crescimento espantoso de membros ligados ao Partido Comunista Brasileiro (PCB), fundação de jornais de esquerda, como A Classe Operária, juntamente com o já existente $A$ Manhãa, o surto de uma literatura considerada subversiva eram os ingredientes de um clima que logo iria ganhar um vulto: Luís Carlos Prestes. "Em fins de 1934, portanto, as autoridades federais pareciam cada vez mais convencidas de que a ameaça comunista era real (...)" (HILTOM, 1986: p. 50). Em março do ano seguinte é fundada a Aliança Nacional Libertadora, com um programa de metas fundado nas seguintes exigências: cancelamento da dívida externa, nacionalização das empresas estrangeiras, expropriação dos latifúndios e distribuição das terras aos camponeses e formação de um governo popular (entre outros pontos). E, na sua primeira sessão pública no Rio de Janeiro, convida o jovem estudante Carlos Lacerda a anunciar como presidente de honra da ANL Luís Carlos Prestes. Lacerda havia escrito seu artigo sobre São Bernardo em janeiro e publicado na Revista Academica. Era figura atuante no Rio, assim como Caio Prado Jr., presidente da ANL, em São Paulo.

Em novembro de 1935, a tão esperada revolta acontece em Natal: "A revolta eclodiu no quartel do $21^{\circ} \mathrm{BC}$ em 23 de novembro, ao que parece sem consulta ao Comitê Central do PCB. (...) Dominado facilmente o quartel, os revoltosos invadiram as ruas, dando tiros e espalhando o pânico" (HILTON, 1986: p. 75). Poucos dos revoltosos eram comunistas na verdade. Conta-se que a população encarou a revolta como pura farra. Saquearam o $21^{\circ} \mathrm{BC}$ e se fantasiaram de soldados. Chegou-se a formar uma junta de governo popular, nomeando-se para cargos executivos do governo alguns cidadãos. Muito em breve as forças federais conteriam a revolta, embora ela tenha chegado aos outros Estados como o boato de um furioso derramamento de sangue.

Mal organizada, reflexo do clima revoltoso do período, iria constituir-se a prova cabal para o governo getulista do perigo que corria a pátria. “(...) Tristão de Athayde, em 30 de dezembro, esboçou um programa anticomunista". ${ }^{159}$ O clamor da imprensa era unânime em favor da prisão dos revoltosos e de qualquer suspeito de conspiração contra a pátria. $\mathrm{O}$

\footnotetext{
${ }^{159}$ Idem, p. 94
} 
Movimento Integralista Brasileiro fundado por Plínio Salgado seria acolhido ampla e largamente pelo governo como um movimento de defesa nacional.

Em 3 de março de 1936 Graciliano é preso em Alagoas (episódio tratado em Memórias do Cárcere). Não se sabe até hoje o motivo: Graciliano foi exonerado do cargo que ocupava no governo em Maceió. Suspeita-se de que um tenente, o mesmo que o levara à prisão, tivera um pedido de favor negado por Graciliano: a sobrinha fora reprovada numa prova de admissão para lecionar, e esperava ele que Graciliano a aprovasse. Recusada a admissão, teria esse tenente ligado diversas vezes ao gabinete do então Diretor da Instrução Pública o ameaçando.

Muito se discute a respeito de sua prisão sem processo. Mas o fato é que o governo decretara o "estado de sítio", o que dispensava qualquer processo em favor de uma atuação mais imediata, sem os processos e sua burocratização, para efetivo detimento dos suspeitos. Tendo, uma semana depois do levante, criado uma Comissão Nacional de Repressão ao Comunismo, conta-se que "Contemporâneos (...) ficaram impressionados com o que parecia ser, às vezes, um fanatismo cego por parte da Comissão e especialmente seu presidente: 'Falta só que te chamem de comunista também', um amigo exasperado comentou com Filinto Müller a certa altura (...)"160 . E o argumento era de que seria melhor fazer uma ou duas prisões injustas do que permitir que o Brasil fosse "ensanguentado de novo". ${ }^{161}$

A fama da Intentona, na época, atingiu dimensões inimagináveis. A ideia de um país ensanguentado, embora fruto da fantasia e do exagero, gerou reflexos na nossa história ainda hoje sentidas. A propaganda que daí surge ostensivamente dominou o imaginário popular a respeito da Revolução de Outubro, ainda hoje presente, embora atenuada. E se a historiografia pouco se ocupa da Intentona, isso não diminui nem sua dimensão histórica atual tampouco os reflexos que provocou no ambiente conturbado da primeira metade do decênio de 30 .

Graciliano só havia publicado dois livros na época. E nos conta em Memórias do Cárcere que José Lins do Rego havia pedido os auxílios do advogado Heráclito Sobral Pinto, figura de destaque da Liga Eleitoral Católica, sob a liderança de Alceu Amoroso Lima (Tristão de Athayde). Sendo avisado de que não havia nenhum processo acusatório, Sobral Pinto animara-se, dizendo que seria mais fácil do que imaginava tirá-lo da prisão. Graciliano se espanta e, ao perguntar por que motivo poderia haver um processo, ouve do advogado católico que havia matéria de sobra em seus livros que permitiriam formalizar uma acusação contra ele.

\footnotetext{
${ }^{160}$ Ibidem, pp. 97 e 98.

161 Idem Ibidem.
} 
De agosto de 1935 em diante os artigos sobre São Bernardo desapareceram. O último foi encontrado na Revista Academica com o título de "O patrão em 'São Bernardo"”. Esse foi um período de extrema e radical vigilância sobre a imprensa. Tanto que é só em 22 de dezembro de 1936 que se voltará a falar de Graciliano: Schmidt escreve sobre a prisão do escritor alagoano no jornal Diário Carioca, fundado e dirigido pelo irmão do chanceler Macedo Soares, José Eduardo de Macedo Soares. Nele o poeta carioca fala da prisão do escritor alagoano como um engano, "em tempos de necessária repressão"162. Curiosamente, no dia $1^{\circ}$ de dezembro de 1935 , um ano antes, o mesmo editor pedia ação veemente do governo Vargas contra os "vermelhos" e uma "depuração rigorosa do funcionalismo público" (HILTON, 1986: p. 94) Agora, o editor, em dezembro de 1936, protestava “(...) diretamente a Vargas contra atos arbitrários do sensor de seu jornal, mas tudo parece ter sido em vão." "163 Ao que nos parece, a essa mudança muito se deve o fato de o irmão do editor, nesse mesmo período, ter-se demitido do cargo de ministro das Relações Exteriores para lançar-se a candidato à presidência da República. Ao perceber sua pouca influência junto à opinião pública, e buscando o fim do Estado de guerra e a liberdade de imprensa, vai, em meados do ano seguinte, ele mesmo, junto com Sobral Pinto, intervir na libertação, ironicamente, não só de Prestes, mas de todos os presos políticos sem processo formal. ${ }^{164}$ Graciliano havia sido solto em janeiro de 1937.

De fato, não só Graciliano estava nessa condição. Havia muitos. Professores universitários, empregadas domésticas; por qualquer que fosse a ligação que algo ou alguém tivesse com a ideia de socialismo, comunismo ou o simples ensinamento das teorias marxistas, haveria repressão veemente por parte do Estado.

Após esse panorama sobre a primeira metade dos anos 30, provavelmente a leitura dos textos a seguir poderá se realizar sem o risco de se achar neles algo de muito ingênuo ou simplório. Claro está, no entanto, que eles mereceriam ainda melhor estudo, segundo suas raízes históricas. Convém agora a prudência de deixar para pesquisadores adequadamente equipados a tarefa de, quem sabe, complementar as lacunas aqui deixadas. Mesmo a respeito da questão literária, que foi o que mais nos preocupou durante toda a pesquisa, não esgotamos de modo algum suas possibilidades. Afinal, o conhecimento que obtemos de uma obra é sempre provisório e atrelado a nosso tempo; aqui se encontra, portanto, apenas uma página de nossa história literária.

\footnotetext{
${ }^{162}$ SCHMIDT, 22/12/1936

${ }^{163}$ Idem, p. 114

${ }^{164}$ Ibidem, p. 163
} 


\section{A RECEPÇÃO CRÍTICA DE CAETÉS (1933-1934)}

Revista Literatura, 05/12/1933

Jorge Amado

Conheci Graciliano Ramos numa viagem que fiz a Alagoas no meiado desse ano. Já lera os originaes de "Cahetés", mas, pareceu-me que compreendi melhor esse romance depois de conhecer o autor.

Realmente me assombrava no livro a sua secura a sua justeza de construção volume onde não ha uma palavra inutil. Nenhum derramamento de linguagem e de lirismo. Nenhum enfeite. Mas romance como o diabo.

Construido ainda um pouco a antiga, escrito por quem possue um estilo geometrico, parece medido, calculado.

Vida de cidade pequena com os seus tipos familiares perfeitamente delimitados. Um detalhe interessante é que os romancistas quando fixam essas figuras provincianas de velhas faladeiras, de farmaceuticos que jogam gamão, promotores burrissimos, falam delas com uma grande ternura, se exgotando em lirismo.

Graciliano Ramos, não. Pinta esse pessoal todo como eles são em verdade. Maus, ignorantes, sem poesia alguma, horriveis de conviver com eles. Essa é a versão verdadeira.

Ha, no entanto, nesse romance sem lirismo, trechos de antologia como o capitulo final que é uma grande pagina.

O heroe do livro é toda a cidadesinha. E' a cidade que impede João Valerio de escrever o romance historico e o faz viver o romance com a esposa do patrão. E' a cidade quem conduz o romance. Porque a cidadesinha é quem faz a vida dos seus habitantes, criticando a sua existencia, creando, por vezes, uma outra existencia.

A gente sae da leitura desse livro, livro de uma realidade pasmosa, com o contentamento de ter descoberto um romancista, porém mal satisfeito com a humanidade. Quanta gente ruim... Eles são assim mesmo, a gente bem sabe. Nenhum heroe desperta simpatia. João Valerio, Luiza, Nazareth, Adrião, o padre, o promotor, quanta gente insignificante, má, perniciosa. E, no fundo, todos se entendem bem, se criticam e se perdoam. Ligeira simpatia desperta apenas aquele bebado que ama a filha e todos os objeto em que ela tocou.

Livro rico sobre todos os aspectos que seja encarado, livro verdadeiro, coloca Graciliano Ramos, ao meu ver, na frente de todos os outros romancistas que surgiram nesses ultimos anos.

O Romance "Cahetés”, Boletim de Ariel, 02/1933

Valdemar Cavalcanti

O que nos impressiona no romance de Graciliano Ramos é a sua força de humanidade, é a sua plastica expressão de vida e movimento. A realidade, attingida pelos processos directos e incisivos do escriptor alagoano, chega a uma rara condensação. Os factos, as cousas, os homens movimentam-se numa atmosphera sem nada de artificial; vivos e exactos, através de uma notavel densidade de descriptivo, transitam pelo primeiro romance de Graciliano Ramos com uma naturalidade que não é a dos heroes e dos casos de mentira. 
Sente-se no Cahetés [que] é a força intima do documento humano; elle é uma luminosa photografia da multidão, realizada por um que acredita naquella realidade historica dos acontecimentos, tão dentro dos grandes romances, de que Duhamel falou num recente ensaio.

Talvez o que mais influa para dar ao Cahetés toda essa impressão de vida, toda essa communicabilidade, seja a segurança de sua factura, o admiravel de sua realização. Graciliano Ramos tem, como romancista, qualidades de poucos no Brasil. Tem uma simplicidade, uma disciplina, uma seccura de fala que fazem o caracter meio exotico de sua phisionomia. Escriptor mais proximo da aridez que da fartura, mais amigo da pobreza que da riqueza de estylo, o romancista alagoano é bem um exemplo vivo de que tambem em litteratura a banha não é signal de saúde, a sua magrem de ossos de fóra é o seu natural, é a sua mais espontanea maneira de dizer as cousas, e não um simples milagre de jejum constante, uma pura renuncia ás plumagens.

Em muitas de suas paginas a gente percebe que Eça deixou nelle marcas fundas, muitas de suas qualidades e alguns de seus defeitos se fixaram, sem o querer do autor, no seu caracter. Porém no corpo do romance ha uma expressão pessoal de narrador. E esse poder de animar os homens e os factos, em Graciliano Ramos, não é resto de banquete de Eça de Queiroz: é cozinha especial, é comida de primeira mesa.

Quando eu li Cahetés, ha tres annos, senti uma impressão de caricatura: caricatura de massa, com a grandeza natural da bôa caricatura mas tambem com as desvantagens de seu sentido de deformação da realidade, apenas. Suggestionei-me que Graciliano Ramos se especializara em maus tratos com os seus heroes, dando-lhes uma vida de escravos e não de gente. E nunca uma impressão foi mais falsa, nunca me trahi tanto a mim mesmo. Todo o pessoal de Cahetés, com quem tive uma apressada convivencia de poucas horas, tem uma vida de gente de carne e osso, intensa e infeliz no seu grotesco. E a prova é que commigo ficaram João Velerio - com a sua paixão de sexo exaltado pela Luiza, mulher do patrão, com os seus enthusiamos litterarios e as suas quedas -, e o Adrião, com os seus achaques e os seus chifres, e o dr. Castro promotor, o padre Athanasio, e as Teixeiras, e o dr. Liberato, medico de procincia, e o Nicoláu Varejão, o das mentiras fabulosas, todos elles. A vida monotona da cidadezinha - Palmeira dos Indios, que serve maravilhosamente de décor ao romance de Graciliano Ramos - fixa-se fortemente em Cahetés, com alguma cousa de grande, de real, de densamente humano.

“Corja”, "Sinhá Dona" e "Cahetés" / "Vida Literária"165, O Jornal, 04/02/1934

Agrippino Grieco

A proposito dos barometros colleccionados pelo tal juiz: muitos romancistas ficam indignados quando lhes constatamos a inferioridade da obra de arte que apresentam. E lá vem desafôro em cima do critico. Mas isso será o mesmo que investir contra o barometro e espatifal-o só porque registra tempo chuvoso. Da minha parte, não tenho prazer algum em

\footnotetext{
${ }^{165}$ A coluna "Vida Literária" foi uma das mais importantes seções de debate crítico do país. Originalmente ela parece ter pertencido ao jornal Diário de Nótícias do Rio de Janeiro. Contudo, tanto o artigo de Agrippino Grieco como o de Octavio Tarquinio de Sousa contêm a informação, em nota marginal, escrita a próprio punho do autor Graciliano Ramos, de que tanto este artigo como o de Tarquinio foram publicados em $O$ Jornal - do Rio de Janeiro. Tendo consultado, porém, os microfilmes das edições de 1934 a 1935 na Biblioteca Nacional do Rio de Janeiro, não consegui localizar nem a coluna tão pouco os artigos dela transcritos nesse trabalho. Mantivemos, assim, a informação obtida nas pastas do Acervo Graciliano Ramos pertencentes ao Instituto de Estudos Brasileiros da Universidade de São Paulo, fazendo a ressalva de que tal detalhe é ainda passível de esclarecimento.
} 
registrar máo tempo nas letras. Sinto-me, ao contrario, alegrissimo quando ha perspectiva de bellos dias, quando ha mesmo a certeza de um bello dia a desfrutar de prompto.

E' o caso deste admiravel romance do sr. Graciliano Ramos, intituldo "Cahetés".

Conheci o autor em Maceió. Passava eu por lá, em direcção a Recife, quando José Lins do Rego, Valdemar Cavalcanti, Aloysio Branco e o sr. Graciliano Ramos me foram buscar a bordo, para, nas duas ou tres horas de parada do navio, correr a cidade, comer um sururú e ver as formosas igrejas da terra. Mas uma das coisas que vi com mais gosto foi o romancista dos "Cahetés", alto, magro, pouco palrador, sem nenhum talento no sorriso, com um geito de revisor supplente de jornal aqui do Rio, dos que recebem sempre em atrazo. Indo para a terra ou voltando para bordo, num desses barquinhos a vela, desarticulados e bambaleantes, que parecem ameaçar-nos sempre de um inquietante mergulho, quasi não lhe ouvi dez palavras.

Leio-lhe agora o volume de estrêa e verifico que tal romance é bem de tal homem. Nada de gastar saliva inutilmente. Nada de consumir papel quando não seja para dizer qualquer coisa realmente proveitosa ao gosto ou á sensibilidade dos demais.

Mas é estranho como esse patricio se conservou assim discreto, pouco verboso, pouco gesticulante, numa zona de derramados, de creaturas que gostam de despejar metaphoras ás carretas nos livros. E que civilizada finura manteve em logares como Palmeira dos Indios, onde o seu livro decorre e onde, se não estou equivocado, foi prefeito, por signal quanto aos frutos da propria administração, alludindo com um desdem, meio swiftiano á sua municipalidade e respectivos municipes.

Hoje é director da instrucção de Alagôas, mas, aos contrario daquelle official superior da instrucção do Eça que perguntava se na Inglaterra havia literatura, sabe que existem literatura ingleza, franceza, portugueza e mesmo brasileira.

"Cahetés" é um bellissimo trabalho, dos que mais me têm deliciado nestes Brasis, em qualquer tempo. Esse homem sequissimo entrou logo para o numero da "minha gente", na minha bilbiotheca. Romance bem pensado, bem sentido, bem escripto e com o minimo de romance possivel. Como que os ossos lhe estão á mostra e, entanto, nada de contundente. Mesmo sem exhibir-se, contendo-se, é o sr. Graciliano um finissimo homem de letras e deve até estar meio envergonhado de escrever direito numa época em que acham que literatura não dever ser literaria, como se a zoologia pudesse deixar de ser zoologica e a astronomia deixar de ser atronomica.

A scena inicial, em que João Velerio fica tonto e desfecha dois beijos no cangote de Luiza, lembra a do rapaz que, amalucado, pespega um longo beijo nas espaduas de madame Mortsauf do "Lirio do Valle". Mas como nosso escriptor faz-nos ver a monotonia com que vão pingando, gotta a gotta, as lentas horas provincianas! Os dialogos podem ser authenticados por quem quer que haja vivido no interior. Cópia das mais conformes. Os jogos cacetes, diversão de preso, demonstração techinica de paciencia cristã, arrastam-se com a tristeza da mediocridade e a rigor são a unica paixão, a unica viagem dessa gente sem leitura, sem amor e sem inesperado na vida. "Jogo encrencado que ninguem entendia, peor que latim" diz o dr. Castro do eterno xadrez em que os parceiros parecem ter-se mecanizado como o enxadrista do barão Kampelen.

Engraçado é que João Valerio, o heróe do livro, se julga medíocre e, entanto, passa a vida a dizer coisas interessantes, ao contrario de tanto outros heróes, que são dados pelos autores como genialmente profundos e passam a existencia toda a dizer besteiras.

A galeria de esquisitões é aqui das mais impressionantes, igualando Lima Barreto. Essas almas empoeiradas, enferrujadas, são provincia mas podiam ser tambem dos nossos suburbios.

O espiritismo continua a ser mina copiosa para os humoristas. Pirandello já o aproveitou no "Mattia Pascal" e sr. Graciliano Ramos não deixa de aproveital-o, com 
habilidade, detendo-se sempre no momento em que a pilheria poderia resvalar para França Junior ou Garcia Redondo. Mas essa fuga das personagens pelos outros mundos, quando não pelo "fradiquismo" das cartas anonymas, ainda é desejo de crear uma diversão ao horrivel tedio dos dias que têm duzentas horas, dos logares em que o minimo bocejo repercute com um estrondo de pororoca. Ah! o horror dessas vidas isoladas e o infortunio do homem que carregue um sonho um pouco menos medíocre em ambiente que taes!

Chegando aqui, assignale-se que, sem decalcomania, o sr. Graciliano Ramos é bem o homem que leu Machado de Assis e Eça de Queiroz. Dizem-me até que leu "Os Maias" umas 10 ou 12 vezes, pelo que devo felicital-o, invejoso de que lhe sóbre tanto tempo para reler o escriptor que foi todo intelligencia no mais inintelligente dos idiomas. De Machado conserva elle um pouco do tom dubitativo, de eterno fronteiriço do "sim" e do "não". Mas a influencia do Eça é bem mais visivel, aliás - repitamol-o - por um effeito de analogia, de consanguinidade espiritual, e não de desastroso mimetismo. A idéa de novella historica referente aos cahetés faz pensar na novella de Gonçalo Ramires allusiva ao antepassado Tructesindo. Chamar o Bacurao de "bacuronico amigo" é um pouco a tonalidade de ironica bonhomia dos João da Ega e dos Thomaz d'Alencar. A indecisão do director da "Semana" sobre se eucalypto é com " $i$ " ou com " $y$ " lembra a incerteza do Damaso sobre se embriaguez era com "n" ou com "m".

Mas com um geitão nitidamente brasileiro reponta no livro quando o morador de Palmeira dos Indios se põe a sonhar com um casamento rico, com uma viagem ao Rio, com um camarote no Municipal! Nisto de contraregrar com tanta felicidade os episodios miudos de logares miudos não sei de livro que me deliciasse tanto depois da obra prima do sr. Godofredo Rangel.

E a preferencia do autor corre manifestamente para os sujeitos carregados de tiques, consumidos por uma idéa fixa, presos a qualquer singularidade maniaca. Gosta mais dos falhados, dos homens sem amanhã, pobres rolhas inuteis bailando no vagalhão da vida, e trata com certa rispidez aquellas suas personagens, como o Barroca, que se revelam mais plasticas, que possuem um sentido social mais activo. O padre Athanasio, se chegar a conego; o dr. Liberato, se estampar um artigo no "Brasil-Medico", já não lhe interessarão tanto. Na paternidade literaria, prefere os filhos feios, meio aleijados moral e mentalmente.

Mas, tratando de uns e outros, que de silhuetas inolvidaveis, em duas ou tres tesourados celeres: o padre "entrando sobre os hombros, que lhe chegam quase ás orelhas"; o typographo, "sargento reformado, sujo, magro, de casquette"; o dr. Castro, "de braços cruzados, bochechudo, vermelho, feliz e sem testa"; o italiano Paschoal, de "tanto sangue, tanto musculo, carcassa tão rija, tudo empregado em dourar molduras de espelhos e rabiscar monogrammas". Num enterro, vêem-se "os individuos que vão aos bailes da prefeitura, os que levam o pallio nas procissões e os que frequentam a "Semana" - commerciantes, empregados publicos, proprietarios ruraes dos sitios proximos". Feliz a observação de que as bellas heroinas do amor conjugal são sempre "fabricadas por poetas solteiros".

A esta altura, devo tambem accentuar, no sr. Graciliano Ramos, a leitura de um escriptor que, mesmo modesto, esquecido ou desdenhado por alguns, está longe de ser um parente pobre das nossas letras: Arthur de Azevedo. O bom Arthur sorriria por traz dos nasoculos ao ver o provinciano que escreve artigos pró e contra o mesmo sujeito, e os letrados de poucas letras que ficam atrapalhados com os vocabulos "euthanasi" e "nevrose" ou com a vida de Marino Faliero e Poincaré. Os exercicios de estylo da redação da "Semana" são do melhor sal gaulez ou carioca e este novo heróe do forte de Copacabana, Nicoláo Varejão, ainda mais engrossa a lista dos dezoito que já sobem a cento e oitenta, como no caso dos bravos do Mindello. O "esprit d'escalier" do João Valerio, que só achava boas respostas dias depois da pilheria que lhe infligiam, é bem marcado. Subtil, e ainda assim lyrica, a passagem brincalhona em que João Valerio dá sciencia do seu amor ás estrellas do céo, e o desdem de 
dona Engracia pelas flores de mulungú é bem de uma zona em que as matronas, ornando as casas com execraveis flores de papel ou parafina, pretendem applicar um correctivo á natureza que fabrica tantos milhares de flores lindissimas...

Quanto ao desfecho do livro é dos mais felizes e parece-me até de extrema originalidade. Difficilmente alguem se sairia tão bem da liquidação final das suas principaes personagens. Exactamente como na vida besta que todos vivemos: o amor de João Valerio e Luiza vem não se sabe como, vae-se não se sabe como. Desejo e saciedade apresentam-se e despedem-se no romance com a mesma naturalidade com que costumam fazer estas coisa na vida. E Luiza, viuva, entra a gerir matronalmente a firma, passado o seu ligeiro enteacto de romantismo, e João Valerio vae aos domingos jantar com Victorino: "Depois do jantar, ficamos á mesa, fumando, tomando café, conversando. A' noite, na sala, o Teixeira toca, Isidoro recita, Victorino cochila - serões bem agradaveis (...)"

Cahetés, Revista Literatura, 05/02/1934

\section{José Lins do Rego}

Há ${ }^{166}$ nos Cahetés de Graciliano Ramos muita gente ruim. Os que são bons são ás escondidas, em momentos de quasi irreflexão. (O caso de seu Pinheiro que brigou pelo heróe contra o promotor foi uma surpresa).

Neste romance intenso e forte a vida é sempre um fardo a carregar. As suas mulheres, quando não são velhotas de fogo morto, são mulheres indecisas ou hystericas, mas todas deste mundo. Ninguem nesse livro doloroso vá atrás de campos floridos, das almas abertas, dos corações generosos. Todo elle é um depoimento da miseria humana, da fraqueza dos homens, de carcteres em decomposição.

O Brasil do interior, de cidades pobres, de cidades marcadas [ilegível] de indigencia physica e palperismo, se acha no Cahetés como nenhum livro da nossa literatura. O Chanaan foi um bello livro porque contou a historia de gente morrendo de fome numa terra exhuberante. Foi um livro de grande tragedia. Mas não ha no romance de Graciliano Ramos essas tragedias em ponto grande como no Chanaan e no Bagaceira. Ha a mediocridade de vidas pequenas, dessas que rastejam como lesmas e que nos arrepiam a snsibilidade de nojo, tudo isto que é doloroso, este cinzento que vem do pequeno quotidiano da existencia.

Lê-se o livro com um travo na alma. E' um romance onde não existe um homem agradavel nem uma mulher bôa, mas é um depoimento dos maiores que nos teem vindo da nossa literatura, tão chegada ao convencional e á moda.

Cahetés não é só um romance que firmou um escriptor em plano alto; é o que ha de mais real e amargo sobre as nossas gentes de cidades pequenas, uma chronica miúda e intensa sobre o brasileiro que não anda em automovel e não veste casaca. E' o pungente livro da nossa pequena burguesia urbana do interior, desses ajuntamentos infelizes que $[\mathrm{t}]$ eem ${ }^{167} \mathrm{um}$ padre, um juiz e um promotor e a pacatez mais asphixiante que o turbilhão. A gente ali é mediocre até na miseria.

O livro de Graciliano Ramos trouxe ao Brasil que se descobre e acorda a contribuição de um mundo que cae aos pedaços. Não ha nada que sirva ali: tudo é mesquinho,

\footnotetext{
${ }^{166}$ A variante acentuada de "ha", menos frequente nos artigos e notas da época, foi a usada no início do texto de fato, mas não se apresentará mais acentudada no próprio artigo de José Lins, marcando a convivência das duas formas.

${ }^{167}$ Erro tipográfico: no texto, a impressão é "leem”. O "t” que aparece no corpo de texto é provavelmente correção feita a próprio punho de Graciliano.
} 
nem um homem nem uma mulher a olhar para cima, a estremecer de felicidade. E o peor é que tudo aquillo é verdade crúa e certa. E ainda querem affirmar que no Brasil só os proletarios soffrem o peso da vida. Estes brasileiros do Cahetés teem direito tambem á revolução.

Cahetés / “Cronica Literária”, Estado de Minas, 21/03/1934

Oscar Mendes

O conhecimento dos romances de Julien Green foi das mais fortes impressões literárias por mim já sentidas. Aquela objetividade, aquela frieza de carrasco, aquela monotonia com que acumulava torturas enlouquecedoras sobre almas mediocres e incpazes de heroismo, aquele estilo sêco, áspero, com agitações, por vezes, de delirio, se conjugavam para impressionar indelevelmente o espírito dos leitores mais calejados e refratários ás emoções de ficção literária.

Suas criaturas faziam parte de uma fauna triste de abúlicos e falhados, de energúmenos e nevróticos, de viciados e de indecisos, de covardes e avarentos. Firmavam uma humanidade lamentavel e cinzenta, cujas paixões e gritos de dôr e desespero mal se elevavam acima da rasteirice quotidiana. Dir-se-ia uma turma processional de réprobos, fugidos dos circulos infernais de Dante.

A leitura do recente livro do sr. Graciliano Ramos, "Cahetés", trouxe-me á lembrança a arte vincante e atroz de Julien Green, especialmente aquela sua mestriia em vivificar almas dolorosas ou mesquinhas, atenazadas por viciozinhos e paixões sórdidas.

Falta, é certo, ao romance do sr. Graciliano Ramos, aquele tom trágico de fatalidade inexoravel que acachapa todos os surtos de libertação e de grandeza que tentem, por acaso, brotar das almas cinzentas e tôrvas dos personagens de Green.

Mas, a igual do romancista francês, o romancista brasileiro analisa, com aquela mesma crueldade de dissecador, um grupo de criaturas frustas, verminadas de pequenos interesses, de pequenos vicios, de pequenas paixões. E, tudo chato, insignificante, quotidiano.

O A. pinta, com exação impiedosa, a vida banal, monótona, grulhante de intriguinhas, das cidades pequenas. Aquela atmosféra corrosiva que reumatisa as mais ágeis personalidades, aquela sucessão tediente dos mesmos minúsculos acontecimentos, aquela avidez doentia do escandalozinho de última hora, aquela ansia incoercivel da malidicência voraz, tudo é reproduzido impiedosamente.

O sr. Graciliano Ramos não tem contemplações nem preferências pelos seus personagens. Todos lhe parecem estranhos e contra êles vai exercendo um trabalho encarniçado de dissecação, de ridiculo, de ironia mordente e feroz.

O próprio protagonista, pela bôca de quem, o A. se faz muitas vezes ouvir, num comentário dicaz, numa observação maliciosa, numa critica sarcástica, não se eleva muito acima da irremediavel mediocridade ambiente.

Muitas de suas atitudes concorrem para no-lo mostrar como um egoista frio, um hesitante, um calculista, um covarde, um aproveitador de oportunidades. As suas próprias veleidades literárias servem para fazer sobresair a sua tôla vaidade e a sua nulidade cultural.

E' um ideciso e ao mesmo tempo um impulsivo. Tem audácias repentinas pagas com insopitáveis terrores consequentes. Num arroubo de paixões pespega beijos no cangote da mulher de seu chefe, mas passa dias e dias num receio temendo das consequências de seu áto. $\mathrm{Na}$ cêna, em que seu chefe, o Adrião, ao haver recebido a carta anônima, reveladora de suas relações amorosas com Luiza, o interpela, acovarda-se, nega terminantemente, sem cavalheirismo nem hombridade. E fica na casa, até que Adrião se suicida. 
Desfeito o obstaculo maior á sua união com Luiza e quando se esperva que assumisse uma posição decidida, dá tempo ao tempo, vai procrastinando, hesitando, titubeando, resfriando sua paixão, e tudo se soluciona justamente por falta de solução.

Os demais personagens afinam pela mesma toada. E' todo um batalhão de ridiculos fantoches, embora admiravelmente traçados e profundamente humanos na exibição de suas mesquinhas misérias, de suas torpezinhas quotidianas.

Barroca, é o tipo da mediocridade bacharelícia e politica que consegue abiscoitar, á custa de traições e cambalachos, os melhores cargos politicos. Miranda Nazareth, o tabellião, é o falso sapiente, pernóstico e metido a crítico, cuja alma soez encontra o mais excelso prazer nas insídias repugnantes da maledicência. No que rivaliza com o ainda mais nojento e sórdido farmaceutico Neves.

O dr. Castro, o promotor, é um chapado animal, que nos deixa hesitante na admiração, entre a sua gordura corporal e a sua tísica mental. O padre Atanásio é de um confusionismo e de uma simploriedade que raiam pela palermice. $\mathrm{O}$ médico, dr. Liberto, um pedante. $\mathrm{O}$ italiano Paschoal um feixe de instintos a explorar o erotismo decadente de d. Maria José, a dona da pensão. O próprio Isidoro Pinheiro, o jornalista, de ótimo coração, caridoso e sentimental, vive obsedado pelas pernas grossas e pela satisfação animal de amores ancilares com mulatas mais ou menos adiposas.

Os tipos femininos não valem mais. Com a agravante de serem mal traçados pelo A. Se os seus tipos masculinos ressaltam pela crueza e nitidez do colorido e do desenho, as mulheres deste livro são incolores e inexpressivas como esboços abandonados.

E' essa gente mofina, insignificante, grisalha, que o sr. Graciliano Ramos faz vegetar, num ambiente provinciano, traçado a agua-forte os seus perfis bisonhos e caricaturescos, com uma frieza assassina de quem se vinga do contacto forçado com a imortal estupidez humana.

O seu estilo sêco, desadornado, econômico de palavras, incisivo e caustico presta-se admiralvelmente ao desenho cruel daquela vida morna e estreita em Palmeira dos Indios.

A crítica tem encontrado no sr. Graciliano Ramos, influências marcantes de Machado de Assis e Eça de Queiroz. Há efetivamente no seu estilo e na composição de seu livro reminiscências daqueles escritores.

A hesitação de Machado de Assis e a ironia acidulada de Eça aprazam-se neste livro. E ainda a recordar o autor da "Ilustre Casa de Ramires", há no "Cahetés" aquele têma do protagonista que pretende escrever uma novela histórica. Na "Ilustre Casa", Gonçalo Mendes Ramires, "o fidalgo da Torre", prepara o seu romance medieval sôbre seu antepassado, o truculento Trutecindo Mendes Ramires. Nos "Cahetés", o guarda-livros João Valerio moureja na feitura de sua novela da época da conquista, narrando as proezas antropófogas dos ferozes Caetés.

Isto, porém, não tira o valor ao romance do sr. Graciliano Ramos, que se revela um excelente narrador, conciso e agudo, e um observador inexoravel das mesquinhezas e ridiculos de uma hunanidade vegetativa, tabalhada pelo tédio e pela sornice de uma existência de horizontes curtos e de ideais pouco acima das elementares satisfações dos instintos. 
A RECEPÇÃO CRÍTICA DE SÃO BERNARDO (1934-1935)

“Critica, Romances” / Diario de Noticias,16/12/1934

Augusto Frederico Schmidt

SR. GRACILIANO RAMOS ${ }^{168}$ - com o seu S. Bernardo nos conduz para a intimidade de um homem brusco e tenebroso, que é não só o personagem principal deste romance, como talvez mesmo, todo o romance. É um sêr aspero, filho de paes incognitos, jogado desde a infancia aos azares de uma vida miseravel, e conhecendo, logo nos seus primeiros contactos com o mundo, a maldade, a impiedade é ${ }^{169}$ a ambição sem nobreza, conseguindo por processos tortuosos se apossar de uma fazenda, S. Bernardo, onde, na sua primeira mocidade, se empregára como trabalhador do eito. Faz logo uma fortuna movimentada, a custo de tudo, mesmo de um crime, e acaba por se casar com uma rapariga pobre, Magdalena, professora de roça, a quem a sua brutalidade desespera a ponto de conduzil-a ao suicidio.

É um romance estreito, pesado, em que sentimos a falta de qualquer doçura, e onde não encontramos um trecho sequer em que a poesia nos permitta descansar da angustiante aridez das paisagens humanas, que o autor nos apresenta. Algumas cenas de "S. Bernardo" são extremamentes bem feitas, como as do ciume, por exemplo, em que o autor revela subtis qualidades de observador de almas, mantendo-se rigorosamente dentro da logica do personagem, dando ao sentimento, do ciume na alma do brutal proprietario de S. Bernardo, os aspectos de pura paixão, de propriedade ameaçada, de grosseira vaidade, sentimento puramente egoistico, em que não entra sequer os dotes da mulher e nem um só movimento de ternura, de inclinação exclusivista.

O processo de romance do S. Bernardo tem, ao meu ver, alguns defeitos dos quaes o principal é a fórma por que o autor nos conta sua historia, fazendo com que seu personagem, de um momento para outro, tenha a absurda idéa de fazer de sua vida um romance, elle, um sêr inteiramente inculto e barbaro, pratico e utilitario. Acho isso, positivamente, arbirario ${ }^{170}$, e em flagrante contraste com o equilibrio psychologico em que o livro transcorre todo. Pelo modo de tratar o assumpto, S. Bernardo recorda vagamente o Le noeud de Vinéres, de Fraçois Muriac. Neste romance é o proprio personagem tambem o autor de sua historia mas em fórma de confissão. Ahi, porém, trata-se de um velho advogado, com inclinações longinquas pela literatura, e com uma série de problemas interiores a resolver, dotado de outra complexidade na sua aspereza e com outras tonalidades tragicas no seu egoismo, que o Paulo Honorio, de $S$. Bernardo não tem.

Mas, essa discordancia do processo do livro do sr. Graciliano Ramos, não the diminue, ao meu ver, a importancia. Trata-se realmente de um livro de um escriptor, prejudicado de raro em raro, por uma especie de cacoête de fazer humour.

Já em Cahetés, seu primeiro livro, o sr. Graciliano Ramos se revelou o mesmo typo marcado de escriptor, a mesma natureza terrivelmente espinhosa, sem flores, e com frutos tristes de um gosto agreste e amargo. Isto, porém, é o que lhe dá, na nossa literatura transbordante e facil, um brilho realmente singular.

\footnotetext{
${ }^{168}$ Falta do artigo definido. Erro que produz o sentido de que o artigo é dirigido diretamente ao romancista.

${ }^{169}$ Muito provavelmente tenha havido um erro aqui: se em vez de "é" lermos "e" obtemos o sentido correto deste período.

${ }^{170}$ Provavelmente erro tipográfico: "arbitrário".
} 
São Bernardo e o Mundo Seco de Graciliano Ramos, Gazeta de Notícias, $24 / 12 / 1934^{171}$

\section{Lúcia Miguel Pereira}

É difícil imaginar-se alguma coisa mais seca do que os livros de Graciliano Ramos. O estilo é seco, seco o ambiente, secos de fazer sede, secos como uma rajada desse vento quente que sopra em dias de verão, levantando uma poeira ressequida e como que queimada.

Pois, parece incrível, mas neste seu último e notável romance o único defeito é ser bem escrito demais. Entendamo-nos: bem escrito demais para ser narrado por esse áspero Paulo Honório que aprendeu a ler na prisão, e tinha tal dificuldade em entender a literatura de normalista da mulher que nada percebeu da carta em que ela lhe comunicava que se ia matar. A narrativa é muito simples, mas ele não a poderia ter escrito. Usa e abusa de expressões regionais e de termos crus, suas zangas explodem sempre em palavrões grosseiros, mas lá vem um momento em que se sente a mão do autor conduzindo a sua.

Aliás, por mais que se procure escrever como se fala, esse é um inconveniene difícil de evitar-se em livros escritos na primeira pessoa, mormente quando o narrador é um matuto bronco e rude como Paulo Honório. O artifício literário fica muito evidente. É a única falha séria de $S$. Bernardo. Os primeiros capítulos são tateantes; os últimos, caem um pouco; mas são defeitos ligeiros. O resto é muito bom, e revela a quem, como eu, não gostou dos Caetés, a admirável força de romancista que há em Graciliano Ramos.

Creio que só se poderá explicar a narrativa pessoal interpretando o livro como uma confissão. Uma confissão implícita, gaguejante, por vezes cínica, mas uma confissão. Era uma alma rude, fechada, a de Paulo Honório, mas não uma alma árida. Na impossibilidade das evocações vislumbra-se de longe em longe como que uma escapada, uma abertura, uma réstia de luz. E para que, senão pra se livrar de uma obsessão dolorosa, haveria ele de escrever a sua vida? Lá está, logo no início, ao findar o capítulo IV, uma prova disso. Depois de contar friamente, a velhacaria de usurário que lhe permitiu apoderar-se das terras cobiçadas de S. Bernardo (muito humano esse desejo de ser proprietário perto do lugar onde trabalhara como alugado), depois de mostrar como explorara o pobre Padilha, acrescenta: "Não tive remorsos". Não teve no momento, mas se não os houvesse sentido mais tarde, quando a dramática passagem de Madalena por sua existência lhe alargara a visão, não diria essa frase. Alma paralítica, mas não vazia. Havia até muito movimento, muita fermentação dentro dela. Foi por isso que, depois da inquietão comunicada pela mulher, a lembraça dos seus crimes the deu uma espécie de senso moral. Foi ela que o educou, que revelou a esse caboclo criado aos trambolhões, ocupado só em subir, em ser rico fosse como fosse, uma vaga noção do bem e do mal. Noção que sentia mais do que entendia. O que lhe devia, ao raciocínio, parecer justo, era a sua conduta, era lograr e matar para ter o seu lugar ao sol. Formou-se na mais dura das lutas pela vida, vendo sempre a vitória do mais forte ou do mais esperto.

Foi preciso conhecer Madalena, e irritar-se com o que chamava o seu sentimentalismo, foi preciso sentir que a mulher, de classe e educação superiores a sua, tratava todavia como seres humanos os seus empregados para perceber que a vida não se resume em ganhar dinheiro. Mesmo sem entendê-la inteiramente, modificou-se com o seu contato. Havia muito da revolta de quem vê, de repente, que não tem razão, no ódio que por vezes ela lhe inspirava. Trabalhara muito para obter o que tinha, e vinha uma moça cheia de

\footnotetext{
${ }^{171} \mathrm{O}$ artigo aqui transcrito encontra-se originalmente em PEREIRA, Lúcia Miguel. A Leitora e Seus Personagens: seleta de textos publicados em periódicos (1931-1943), e em livros / Rio de Janeiro: Graphia Editorial, 1992. Não se encontra entre os textos coletados do Arquivo Graciliano Ramos, Fortuna Crítica, do Instituto de Estudos Brasileiros.
} 
idéias complicadas a querer que desse aos outros uma proteção que nunca tinha recebido. Exasperou-se contra ela, maltratou-a, atormentou-a com ciúmes mórbidos, provinientes talvez da impossibilidade de entender-lhe a conduta, levou-a até ao suicídio, mas no fundo não lhe queria mal, nem se pôde fechar à sua influência.

Que figura bem construída, bem lançada, cruelmente verídica e muito humana mesmo em seus excessos, esse Paulo Honório, com as suas mãos enormes, calosas, a sua face vultosa, as sua maldade indiferente, a sua profunda incompreensão de tudo o que não fosse um negócio e, sob tudo isso, um ou outro movimento bom.

Depois de liquidar, ou mandar liquidar, numa tocaia o velho Mendonça, um vizinho com quem tinha questões de terra, arvora-se em protetor de duas solteironas, filhas da vítima. Nas terras de São Bernardo, extorquidas ao Padilha, a quem depois vale com um lugar de professor na escola da fazenda, faz questão de oferecer um abrigo confortável à Margarida, a preta doaceira que o recolhera, quando menino.

E não só ele, mas todas as personagens vivem. D. Glória, seu Ribeiro, o Padilha... tudo gente de verdade. Madalena, sem dúvida por não a ter nunca chegado a entender inteiramente o narrador, é uma figura meio esbatida e enigmática. É realmente o centro do livro, irradia a sua influência sobre todos os outros, mas fica na sombra. Sabe-se o que ela faz, mas não o que é, intimamente. Há um quê de misterioso nessa mulher que se casa por dinheiro e tem idéias socialistas, que se descuida do filho e vive preocupada em suavizar a miséria dos moradores de $\mathrm{S}$. Bernardo. Parece haver muito de intelectual em suas teorias e na sua bondade, mas não se sabe ao certo.

Há várias cenas muito boas no livro, algumas muito naturais apesar de um certo tom caricatural, como o pedido de casamento; outras de intensa dramaticidade, como todo o episódio dos ciúmes e a entrevista de Paulo Honório com a mulher, na igreja vazia, na noite que precedeu a morte desta. Mas, entre todos, existe um capítulo de estranha beleza, revelando no autor uma grande maestria e um raro poder de sugestão. É aquele onde, procurando recordar-se da mulher, o narrador, na meia-luz do crepúsculo, vai insensivelmente confundindo o presente e o passado.

"O tic-tac do relógio diminuiu, os grilos começaram a cantar. E Madalena surge do lado de lá da mesa. Digo baixinho:

- Madalena!

A voz dela me chega ao ouvidos. Não, não é aos ouvidos. Também já não a vejo com os olhos."

A meia alucinação vai crescendo, empolgante. Lembra Green, mas um Green humanizado, onde houvesse, soando em surdina, a doçura de uma nota de ternura.

"S. Bernardo" de Graciliano Ramos, Boletim de Ariel, 12/1934

Aderbal Jurema

Li ainda no original o segundo romance de Graciliano Ramos. De Cahetés para o São Bernardo o romancista realizou uma admiravel ascenção. Ao contrario do que succedeu ao poeta Jorge de Lima depois da publicação do O Anjo. O que, de algum modo, salvou o poeta alagoano foi a humanidade que elle soube imprimir ao padre Joseph Anchieta, no seu ultimo livro. No entanto, a gente encontra ás duzias pelo seu trabalho - guerra bonita - quando se refere ao miseravel trucidamento dos indios pelos agentes de cruz e espada da colonização portugueza. Mas são coisas de poeta que não desce de seu arranha-céo para se misturar com 
as gentes das ruas. Mesmo assim, com muitas outras falhas de observação, prefiro o Anchieta ao $O$ Anjo, que em recente artigo, publicado na edição de anniversario do Diário de Pernambuco, Olivio Montenegro classificou de "nem anjo e nem diabo". E' o mesmo que dizer: - coisa nenhuma, livro falhado.

Mas vamos ao São Bernardo deste outro escriptor alagoano. Embora não seja um romance de massa, porque a historia que Graciliano Ramos teceu gira em torno de um fazendeiro, o livro é um documento honesto da vida de fazenda nordestina. Aquelle Paulo Honorio representa muito bem o typo do fazendeiro capcioso e cheio de defeitos da sua classe. O ciume morbido pela mulher, as scenas de selvageria com os moradores e o despotismo feudal têm uma forma muito intensa de realidade. Mas, de accôrdo com o que Paulo Honorio diz no fim do livro, elle não possuia a culpa de ser ruim. A ruindade delle era uma resultante da maneira como conseguiu "vencer" na vida! De conformidade com o meio, elle para ser alguma coisa tinha de fazer tudo aquillo, proceder de toda fórma para afastar os concurrentes, contando que chegasse a ser dono do São Bernardo. E o Padilha, que sugeito curioso! Um typo complicado de idealista e de covarde. O que se destaca, acima das suas outras qualidades, no romancista de São Bernardo, é o poder muito forte que elle possue de descrever seus personagens em perfeita correspondencia com o ambiente onde se desenvolve a historia do romance. Até o adulterio com a mulher do Marciano. Até aquella gratidão com a mãe-preta Margarida. Tudo muito humano, muito nosso, de um regionalismo puro e verdadeiro.

Falta no romance o drama do trabalhador do eito. A tragedia intima entre Paulo Honorio e a mulher, as ciumadas riduculas e o temperamento abrutalhado do marido, absorveram completamente os homens do eito, a vida do campo, a exploração feudal do fazendeiro, tudo emfim que se relacionasse com a lucta economica, com a miseria humana, com o desconforto dos pobres diabos que levavam braço no pé do ouvido quando a revolta apparecia nos labios. Como succedeu no caso do Marcolino. ${ }^{172}$ E' verdade que temos uma idéa da lucta de classe pelas referencias de Magdalena. Pelo "socialismo" do Padilha, que terminou como soldado da "revolução liberal", caso de uma generalização unica no Brasil de 1930. E mais algumas referencias apenas aos casebres humidos e frios. A gente dos casebres humidos e frios não tomou conta do livro. Apparecia sempre como panno de fundo das brigas de Paulo Honorio com Magdalena. Já no Bangüê, embora a vida de Carlos de Mello seja a movimentação em primeiro plano, a lucta dos cabras de eito, a vida destes parias, actua mais impressionante no livro, toma parte mais saliente do que no São Bernardo.

Os dialogos são bem organizados e se estendem naturalmente, sem o escriptor forçar os personagens. Elles falam por si, ausentes da censura directa do romancista. Este, em São Bernardo, puxa os cordões dos mamolengos humanos e elles começam a agir. $\mathrm{O}$ unico que soffre directamete a influencia do temperamento secco do autor é o Paulo Honorio. Mas, assim mesmo, ás vezes, elle vira um poeta regional. O "seu" Ribeiro, contando a sua vida, nos communica alguma coisa mais forte do que simples piedade para com a sua decadencia. Esta alguma coisa me parece muito poesia. Uma poesia que podemos chamar de recordativa. Quantas vezes estamos a evocar, num logar esquecido, a vida que ficou atraz e os acontecimentos antigos, ás vezes, banaes, vêm chegando, devagarinho, com uma suavidade tão bôa, que nos entregamos a elles e nos deliciamos, silenciosamente, em recordal-os com um gozo quasi doentio. Gozo de revivel-os e sofrimento por não podermos recuar no tempo.

\footnotetext{
${ }^{172}$ A referência exata é a Marciano. Pode ser que, por ter lido nos originais, este nome fosse a primeira opção para o personagem.
} 
A' primeira vista, poderá observar-se neste "S. Bernardo", do sr. Graciliano Ramos, um certo excesso de criticismo, de auto-analyse. Como que as personagens se sentem viver demais, olham demais para a vida. O protagonista parece-nos muito lucido, muito abundante em cemmentarios, o que é estranhável em creatura de poucas lettras, oriunda de ambientes agrestes, não afinada pela leitura de psychologos e romancistas introspectivos.

Enxerga-se aqui o mundo em quadrinhos literarios e os homens surgem sempre em funcção de figuras de livro. Quasi se chega a concluir que no sr. Graciliano Ramos, acima de um ficcionista, ha um grande ensaista, um grande intellectual, antes destinado a criticar os creadores que a crear por conta própria. Seu tinteiro apparece sempre, sua caixa de titeres está muito á mostra.

Mas leia o romance sem apriorismo, admitta-se a maneira do autor, sem rebeldia em acceital-o tal qual é, e reconhecer-se-á que elle, mau grado essa presença constante em tudo o que escreve, é um notavel romancista. Até o uso dos rifões e phrases sertanejas prova que não ha no sr. Graciliano Ramos nenhuma arrogancia de estheta, nenhum orgulho de artista que observe tudo refrangido numa estante de livros.

Achei nelle um dos maiores amigos do meu espírito, dentre os que fiz ultimamente, e este "S. Bernardo" não deixa de rebuesecer a admiração com que recebi os "Cahetés".

Talvez exista um pouco de optica dos inglezes desse escriptor, em se tratando de examinar coisas do Nordeste que nada tem a ver com o "fog" londrino ou a gaita de foles dos escossezes. Mas quando intervem um factor de real intensidade humana, como a parte do ciume de Paulo Honorio pela mulher, não mais perduram reminiscencias de Sterne ou qualquer outro, recebidas directamente ou através de Machado de Assis, e é um arrepio de paixão, um bolo na garganta, são uns accesos de maluqueira bem nossos, bem da impulsiva gente dos tropicos. O que existe aqui de vida literaria não impede que circule pelas paginas do volume vida de verdade.

Naturalmente o autor é um homem culto e falta-lhe, em varias scenas, o abandono, a ceguira, a inconsciencia maternal de tantos productores de livros que vão ao extremo de julgar os seus monstrengos mais formosos que Ariel ou Euphorion. Bem se vê que o narrador se diverte um bocado com os typos do "S. Bernardo" e mal occulta um sorrizinho ironico ao movimentar esses actores, ao enscenar as principaes passagens do romance. Ter-se-á a impressão de que elle parte de uma idéa para os factos e não viceversa, como conviria a um docil, a um fidedigno reflector de acontecimentos.

Mas acaso o melhor romance ou conto de hoje não une a cultura aos instinctos, não exige a contribuição do "eu" do autor, não é tambem uma critica aos sêres e á ambiencia. Basta lembrar Pirandello e Unamuno, amigos dos jogos cerebraes, verdadeiros entomologistas de almas, colcelcionadores ${ }^{173}$ de typos bizarros, de quasi-homens ou sub-mulheres, para concluir que ha até um encanto maior na malicia do nosso metteur en scéne"174, ao falar do padre Silvestre, do João Nogueira, do Salustiano Padilha, da filha do dr. Magalhães.

Se ás vezes o sr. Graciliano Ramos complica um sertão simplorio é no interesse da obra de arte, que não poderia existir se elle se submettesse de todo ao rudimentarismo de almas da região. Logo, indicar o que elle levou de convencionalismo literario aos themas não importa em nenhuma resticção quanto á essencia do seu talento, ao talento do escriptor em si.

\footnotetext{
173 Coleccionadores.

${ }^{174}$ Falta de aspa: erro tipográfico.
} 
Em geral, as personagens dos regionalistas brasileiros se esgarçam em sombras, o que é estranhavel em paiz do tanto sol quanto o nosso. Não assim as do sr. Graciliano Ramos.

Padecem ellas de uma ou outra reminiscencia literaria. O principal heroe apresentase assim: "Começo declarando que me chamo Paulo Honorio" e que lembra um pouco o "Começou por me dizer que o seu caso era simples e que se chamava Macario", das "Singularidades de uma rapariga loura" de Eça de Queiroz.

Mas o exacto é que os typos se situam canãs. Com as ultimas chuvas a represa, bem nos incidentes, estão muito bem marcados em suas caracteristicas de differenciação, e não ha confundil-os em nossa memoria. O pessimismo encolhido, manso, do autor e rico de detalhes em que se pescebe ${ }^{175}$ o sentimental contradictado, talvez um metaphisico que pretende ter horror á philosophia.

Houra-o tambem a sua tendencia para o universal, o desejo de localizar os seus heroes miudos numa atmosphera, não meramente local, e sim de uma importancia que transcenda das fronteiras do Estado, que seduzam as almas de outras latitudes.

Em summa, ha um civilizado, um grande civilizado nesse sertanejo que trata de sertanejos. A dose de fatalismo arabe que vae pelo livro, que se espalha por tantos corações somnolentos, como que torna o romance sonoro para uma repercussão nos espiritos longinquos. Em minucias apparentemente brincalhonas, que de encontros com a ternura crispada dos slavos! Aquelle que parece divertir-se com os seus bonecos é, no fundo, um indignado com as miserias que descreve e só um pudor de homem avesso ao palavreado demagogo o contem numa especie de imparcialidade altiva que a ninguem iludirá.

Vê-se que o respeito com que Paulo Honorio fala de Casimiro Lopes, que é "corajoso, laça, rasteja, tem faro de cão e fidelidade de cão". Paulo rouba a terra dos outros, mete o chicote num jornalista que não o elogia, mas refere-se com doçura á mãe Margarida:

"Entreguei a carta a Casimiro Lopes, tomei o chapeo e fui fazer minha segunda visita á preta. Desci a ladeira. Ao atravessar o paredão do açude, amedrontei uma nuvem de marrecãs e ja-augmentara muito[sic], os bancos de baroneza estavam com vontade de entupir o sangradouro. A levada que ia ter ao descaroçador e á serrania transbordava. Fechada a serraria, fechado o descaroçador. Dia perdido.

Encontrei Margarida sentada numa esteira riscando os tijolos com carvões.

- Mãe Margarida [sic] como vae a senhora?

Tentou endireitar o espinhaço emperrado e, antes de lançar-me os olhos brancos, reconheceu-me pela voz.

Aqui gemendo e chorando, meu filho, cheia de peccados.

Peccados! Antigamente era uma santa. E agora, miudinha, encolhidinha, com pouco movimento e pouco pensamento, que peccados poderia ter? Como estava com a vista curta, falou sem levantar a cabeça, repetindo os conselhos que me dava quando eu era menino. Uma fraqueza apertou-me o coração, approximei-me, sentei-me na esteira, junto della.

- Mãe Margarida [sic] procurei a senhora muito tempo. Nunca me esqueci. Foi uma felicidade encontral-a. E carecendo de alguma coisa é dizer. Mande buscar o que for necessario, mãe Margarida, não se acanhe.

Olhou com espanto as cadeiras, a mesinha, a lampada electrica, os moveis do quarto proximo.

- Para que tanto luxo? Guarde os seus trocos que podem servir. Em cama não me deito. E que dá o que tem a pedir vem.

- Não faz mal, mãe Margarida. Esteja socegada, durma socegada. Faltando lenha para o fogo, avise. Não deixe o $[\ldots]^{176}$

\footnotetext{
175 Percebe.

${ }^{176}$ Os últimos parágrafos foram cortados à tesoura a partir desse trecho.
} 
Muita gente que anda escrevendo por aí pensa, ${ }^{177}$ que fazer literatura é transplantar para o papel, o ridiculo e bastante estupido linguajar regionalista (sic) pensa que interpretar a alma e o sentir do nosso matuto, é só compor frases sem expressão, e mais ainda, contra a estetica da forma literaria.

Este vicio, com o tempo tornou-se em habito, em tendencia formando uma outra escola de literatura, já vitoriosa em todos os sectores da atividade mental aqui no Brasil.

Só compreendo duas razões para que o individuo escreva, duas razões para que se publiquem livros: ou o individuo faz obra de arte ou faz, unicamente obra de estudo. Fóra destas duas razões ficam os escrevinhadores vulgares que só escrevem pela volupia imbecil de escrever. Essa é a verdade.

O apparecimento do "S. Bernardo" do sr. Graciliano Ramos, inspirou-me a vontade não pequena de afirmar algo sobre essa nova tendencia do romance brasileiro. A distancia que vai de "Cahetés" á "S. Bernardo" é bem grande e a diferença entre os dois romances do novo romancista do norte, é por demais sensivel, para que fique sem comentarios.

Em "Cahetés" o sr. Graciliano Ramos, deixou transparecer claramente a tendencia para a literatura regional. Esse o mal inicial do romance, pois, esta literatura, encabeçada e escrita em ortografia caipira, está fadada, como toda a obra de pouco folego a uma vida efemera. Somente a obra de arte, que interprete com fidelidade o ritmo de vida social, ficará para sempre: as demais desaparecerão tragadas pelo tempo, porque na ficção a arte está na interpretação fiel da vida objetiva.

Em "S. Bernardo", pelo contrario, o sr. Graciliano Ramos, não procurou sintetisar quadros de uma vida real imaginada, mas muito pelo contrario, procurou ver a vida como ela deve ser vista: com realismo, sem excessos de pintura e nem de imaginação previlegiada. Fez livro completo.

"S. Bernardo" é uma autobiografia de um individuo medíocre. E passagem de um homem pelo mundo que chamou-se Paulo Honorio: "Começo declarando que me chamo Paulo Honorio, peso oitenta e nove quilos e completei cincoenta anos pelo S. Pedro."

A forma, como o entrecho, é originalissimo. A atração do romance esta mesmo na originalidade do enredo e da forma.

O sr. Graciliano Ramos, é um romancista de fato. Todas as figuras que ele ativa, são figuras reaes e não imaginarias. Prefere mais a descrição simples e expositiva á linguagem decadente de floreios retoricos. Como Jorge Amado e Lins do Rego, é um romancista totalmente moderno.

\section{O Estado de São Paulo, 05/01/1935}

\section{Plínio Barreto}

O romance "S. Bernardo" do sr. Graciliano Ramos é um forte e esplendido estudo do ciume no espirito rude de um homem grosseiro, brutal e cynico. Este soliloquio do ciumento dá uma idéa da maneira do escriptor e dos seus dotes psychologicos: "O senhor conhece a mulher que possue". Conheccia nada! Era justamente o que me tirava o appetite. Viver com

\footnotetext{
${ }^{177} \mathrm{O}$ autor emprega uma pontuação estranha, separando o sujeito e o verbo com vírgula, o verbo e o objeto, ou não a empregando em casos necessários.
} 
uma pessoa na mesma casa, comendo na mesma mesa, dormindo na mesma cama, e perceber ao cabo de annos que ella é uma estranha! Meu Deus! Mas se eu ignoro que ha em mim; se ignoro muitos dos meus actos e nem sei o que sentia naquelles mezes compridos da tortura! Já viram como perdemos tempo em padecimentos inuteis? Não era melhor que fossemos como os bois? Bois com intelligencia. Haverá estupidez maior que atormentar-se um vivente por gosto? Será? não será? Para que isso? Procurar dissabores! Será? não será? Se eu tivesse uma prova de que Magdalena era innocente, dar-lhe-ia uma vida como ella nem imaginava. Comprar-lhe-ia vestidos que nunca mais se acabariam, chapeus caros, duzias de meias de seda. Seria attencioso, muito attencioso, e chamaria os melhores medicos da capital para curar-lhe a pallidez e a magreza. Consentiria que ella offerecesse roupa ás mulheres dos trabalhadores. E se eu soubesse que ella me trahia, matava-a, abria-lhe a veia do pescoço, devagar, para o sangue correr um dia inteiro. Mas logo me enjoava do pensamento feroz. Que rendia isso? Um crime inutil! Era melhor abandonal-a, deixal-a sofrer. E quando ella tivesse viajado pelos hospitaes, quando vagasse pelas ruas, faminta, esfrangalhada, com os ossos furando a pelle, costuras de operações e marcas de feridas no corpo, dar-lhe uma esmola pelo amor de Deus. Seria, não seria? Insignificancias. No meio das canseiras a morte chega, o diabo carrega a gente, os amigos entortam o focinho na hora do enterro, depois esquecem até os pirões que filaram".

A victima do ciume, para ser bem interessante, devia ser innocente. E era-o, de facto. Acabou suicidando-se e o ciumento, chicoteado pelo infortunio, entrou em si e só então começou a ver as coisas com os olhos desarmados. Veiu-lhe o passado á memoria e, com elle, uma tristeza infinita pelo rumo que havia tomado na vida. Se tivesse permanecido na humildade inicial, se houvesse casado com uma cabocla, como elle, "possuiria meia duzia de cavallos, um pequeno cercado de capim, encerados, cangalhas, seria um bom almocreve. Teria credito para comprar cem mil réis de fazenda nas lojas da cidade e pelas quatro festas do anno a mulher e os meninos vestiriam roupa nova". E concluiu, num suspiro: "Os meus desejos percorreriam uma orbita acanhada. Não me atormentariam preoccupações excessivas. Não ofenderia ninguem. E, em manhans de inverno, tangendo os cargueiros, dando estalos com o buranhem, de alpercatas, chepeu de ouricuri, alguns nickeis na capanga, beberia um gole de cachaça para espantar o frio e cantaria por estes caminhos, alegre como um desgraçado... Hoje, não canto nem rio...” Estraguei a minha vida. Estraguei-a estupidamente. Sou um aleijado. Devo ter um coração meudo, lacunas no cerebro, nervos differentes dos outros homens. E um nariz enorme, uma bocca enorme, dedos enormes..." Querem conhecer melhor o homem. Aqui está a sua religião. "A verdade é que não me preoccupo muito com o outro mundo. Admitto Deus, pagador celeste dos meus trabalhadores mal remunerados cá na terra, e admitto o Diabo, futuro carrasco do ladrão que me furtou uma vacca de raça". A sua philosophia de vida não é mais subtil: "A verdade é que nunca soube quaes foram meus actos bons e quaes foram meus actos maus. Fiz coisas bôas que me trouxeram prejuizo; fiz coisas ruins que me deram lucro". Em torno da personagem principal, agrupam-se figuras curiosas, todas bem carcterizisadas, e desdobram-se, na variedade de aspectos, qual a qual mais interessante, o scenario de uma povoação sertaneja e os quadros de uma vida rural em que a monotonia é temperada, como no antigo despotismo dos czares, pelos assassinios. Livro attrahente mas semeado de surpresas desagradaveis, pois que a grosseria, com que tratava a esposa e os amigos, o heróe a estende tambem aos leitores. O palavrão, aspero e obsceno, salta-lhe da bocca na presença de quem quer que seja. E' verdade que o leitor moderno, maxime se é frequentador das rodas que dão ao tom na sociedade, deve estar familiarisado com palavrões. Talvez não tenha, por isso, as surpresas de que o adverti. Tanto melhor. 
"Seu" Paulo Honorio conta a sua vida desde criança. Filho das hervas, guia de cégo, vendedor dos doces da preta Margarida, trabalhador de enxada, preso por trez annos, nove meses e quinze dias por ferimentos, eleitor, negociante ambulante no sertão, justiçando os seus devedores com as proprias mãos, e afinal, estabelecendo-se na sua terra onde adquiriu o "S. Bernardo". Trabalhara na mocidade a terra de que se tornou dono. Amanheceu um dia pensando em casar. Ahi é que começu ${ }^{178}$, realmente, o romance para o sr. Graciliano Ramos. Um encontro fortuito com uma senhora nova e loura que sorria, decidiu a vida do "seu" Paulo Honorio. Era Magdalena, professora, com quem se casou. Os ciumes do marido, fundados na differença de idade, temperamento, educação e habitos, enchem as paginas do romance, até que, não podendo mais, a pobre se matou e "seu Paulo", aborrecido da vida, dá para escrever historias. E' esse, em resumo, o romance do sr. Graciliano Ramos.

Antes de tudo, a forma directa empregada no "S. Bernardo", preferida certamente pelo seu autor com a intensão de dar maior intensidade á analyse psychologica, para compensar talvez a sua seccura e a quasi rispidez com que modela os seus personagens, não basta para dar ao romance interesse emocional, podemos dizer auto-biographico, que é tudo que resta da nobreza do genero, e que pode justificar ainda um romance. O "S. Bernardo" é uma daquellas applicadas "tranches de vie" que fizeram os encantos dos nossos maiores. $\mathrm{O}$ narrador da vida de "seu" Paulo Honorio não é, evidentemente, o personagem, aliás apenas indicado, o ex-guia de cégo, o ex-vendedor de doce, o ex-trabalhador alugado, o homem rude de modos truculentos, meio-cangaceiro, que ajuntou, de alma damnada, o dinheiro bastante para se apoderar da terra onde ganhara no eito o salario de cinco tostões. Toda a força emocional que poderia ter o romance, isto é, a realidade palpitante de vida, de um homem como esse, brutal e soffrego da propriedade, obstinado na sua vontade de se elevar acima da sua condição social, no seu desejo inedeterminado de vingança contra o meio hostil que conseguira dobrar, dia a dia, atravez da mais dura experiencia, todo o interesse que poderia despertar a apresentação daquelle homem em funç̧ão do meio social, da lucta furiosa pela terra, das monstruosas condições de trabalho, da ambiencia feudalizante do sertão, e até mesmo da paisagem da desolação em que se movessem as creaturas que o romancista suscitasse, são liquidados, ante o que o autor passa a considerar o romance de "seu" Paulo Honorio, - uma descosida historia de ciumeira, mais digna de figurar na biographia sentimental do ultimo pequeno-burguez da cidade, de que na historia daquelle rude sujeito esboçado no livro.

Si o romance do sr. Graciliano Ramos parece irremediavelmente compromettido pelos proprios fundamentos, ainda assim, revela-nos um excellente escriptor no que se poderia denominar de pintura superficial de caracteres. E' verdade que os seus personagens, picados não sangrariam. Mas denotam uma attenção acurada. A professora romantica, totalmente deseducada, que, é claro, acaba desequilibrada com o meio; as figurantes lamentaveis do interior; o padre politico, o advogado matreiro e o juiz venal; o guarda-livros infeliz e o professor madraço, que, ambos, acabam girando na orbita da professora, enamorados piegas de uma revolução que não sabem bem o que é, e que por isso se confundem, na mesma inanidade, [são] castigados não tanto pelo desprezo de "seu" Paulo Honorio, como pela indifferença (sic) dos trabalhadores.

\footnotetext{
${ }^{178}$ A ambiguidade aí provocada tanto pode derivar de duas possibilidades de erro tipográfico: “começou” ou "começo".
} 
Este romance, "S. Bernardo", de Graciliano Ramos, autor de certo fôro em nossa actualidade literaria, exemplifica o descaso com que os novos valores lidam com a literatura, e por ella se desapreçam no conceito publico. Seduzidos por um principio falso de independência mental, tomam por espontaneidade o que não passa de desleixo, estimam no erro deliberado uma manifestação de audacia e crêm que haja expressão revolucionaria em attitudes que, ás vezes, enojam, mas quasi sempre apenas enfaram o bom senso de letrados e não letrados.

A creação literaria exige sinceridade, perseverança, equilibrio e não apenas intelligencia creadora. Desde que não haja o ajustamento da virtude natural a uma vontade honesta e disciplinada, os esforços serão gastos sem proveito maior, e a obra nunca attingirá definitiva formação. E' o quem vem succedendo em numerosos casos do momento. Intelligencias fortes, bem dotadoas, que poderiam render optimo fruto, dentro das possibilidades ambientes da época, exhaurem-se em tentativas mais ou menos falhas, sem consistencia intelecttual e despidas de provimento moral ou social ponderavel. Em taes malsinados ensaios perdem-se motivos não raro execellentes, desconceituam-se valores essencialmente dignos de apreço e, peor que tudo, desprimora-se o conceito da literatura nacional de uma época.

"S. Bernardo" é um exemplo desse malentendido apreço á independencia mental. A exploração inicial do romance, que pretende ser engenhosa, parece-nos simplesmente ingenua. $\mathrm{O}$ autor, inculto, teria recorrido a outros companheiros, de mais puras letras, afim de lhe fixarem a narrativa sem a eiva da ignorancia. Desistira, no emtanto, logo ao começo, por encontrar a narração preciosa. Escreve-a, então, elle mesmo, com a mão que se presume inhabel, rude, crassa.

Isso não impede que no livro se encontrem discursos formaes, de superior polimento literario. Dahi concluir-se que o autor pretendeu apenas justificar certas passagens em calão brutal. De qualquer modo, porém, esse tosco recurso inicial, que a obra não justifica, desmerece-a. Ao menos como testemunho de rebaixamento literario do autor e do seu descaso pela intelligencia do publico. A mesma pretensão á naturalidade e á autonomia intellectual leva-o a enfeial-a e desmerecel-a em pontos essenciaes: precario retraçamento de figuras, displicencia no trato de ambientes, mão debil na fixação de episodios indicados[,] a influencia fundamental na impressão conjunta do romance, grosserias de linguagem perfeitamente ociosas.

Taes impedimentos de gosto literario e de senso commum perturbam a unidade da obra e retêm o conceito sobre o valor do romancista em limites que poderiam parecer injustos se apenas se o contasse pelo essencial, mas que, de facto, exprimem voto natural e sincero de consciencia.

Em "S. Bernardo" ha substancia de um bello romance, capaz de impressionar pelos motivos humanos e pela força de ambiente. Lastima-se que o autor tenha dispensado a essa materia prima outro brio intellectual, imprimindo-lhe a unidade plastica e a energia de expressão que devidamente a consolidassem numa estructura legitima, resistente, duravel. 
A Margem do “S. Bernardo”, Especial para o Diario de Pernambuco, 25/01/1935

Olivio Montenegro

O paradoxo, por menos viavel que isso pareça, tem o seu ponto humilde de contacto com o logar commum o que é mais um signal de que os extremos se tocam - e este ponto de contacto vem do facto de usarmos passivamente de um e do outro; de elles se imporem á nosso campo de consciencia, assaltando os nossos direitos de critica.

A differença está somente em que o logar commum é um producto do habito, e o paradoxo um producto da suggestã. Aliás muito logar commum no começo é possivel que tenha gozado uma vida de paradoxo, e muito paradoxo é possivel que se tenha relaxado em logar commum.

Isto vem a proposito de um paradoxo de Oscar Wilde, que de tanto se repetir já está perto de passar a logar commum - e é o paradoxo de que não é a arte que imita a vida mas a vida que imita a arte. Um paradoxo irritante de audacia intellectual. Se a vida imitasse a arte seria necessario que a arte fosse anterior e aparte da vida, e ainda mais: seria necessario concebermos a vida com uma consciencia particular de ser, o que se contrapõe á noção universal que se tem da vida. Este paradoxo de Wilde é uma pura reverberação de espirito, mas de um effeito que offusca muita intelligencia alerta a dona de si. Agora, onde não ha duvida, me parece, é que a arte não é uma copia da vida, não tem uma funcção meramente passiva de espelho.

O romance, por exemplo, que é a forma de arte de um campo mais aberto de projecção para a vida, nós notamos que elle dá sempre em uma pobre coisa, ou em um triste ridiculo, toda a vez que procura ser uma reproducção exata e material da vida. Elle não reflecte da vida nesses casos mais do que um espelho de bolso pode reflectir do Hymalaia: a parte banal e insipida do detalhe.

O medo que faz do exaggerado amor á chamada cor local da parte de certos autores é que elles nos queiram dar a vida com todas as letras nos seus romances, que elles nos repitam a vida, como se a vida por si mesma não tivesse um poder que ás vezes já parece idiota de repetição. $\mathrm{O}$ fim da arte é antes realizar o que a vida suggere aos nossos sentidos, ou crear ${ }^{179}$ novas suggestões. E' resolver pelo espirito uma unidade que os nossos sentidos não podem representar nunca. E se não fosse assim seria a arte photographica a mais completa e imitavel das artes. De maneira que podemos dizer de um livro que elle é bom não apenas quando elle nos commove sentimentalmente, como uma fita de cinema, mas quando elle intensifica ou augmenta as nossas sensações de vida, quando elle cria uma surpreza para os nossos sentidos.

Se a tendencia para associar os outros ás nossas convicções não fosse tão traiçoeira ao nosso amor proprio, eu diria que o sr. Graciliano Ramos quando escreveu "S. Bernardo", o fez com a plena consciencia de que a arte não é uma lacaia da vida. E escrevendo um romance de cor regional elle não insiste na exposição de detalhes, na "cor local", para o premeditado effeito do pitoresco. Não faz do seu romance um bric-á-brac de phrases e coloridos para todo o gosto. Antes, muitas vezes, elle reteza-se demais numa attitude de intransigencia. Porque "S. Bernardo" não deixa a impressão de um romance que sahisse aos jactos de inspiração, corrente e livre como a agua jorra da fonte. Mas de um livro vivamente trabalhado, um livro em que o autor e o critico nunca estiveram separados. São duas funcções que nem sempre conjugam bem; o critico é sempre mais exigente do que o autor e de vez em quando o está interrompendo e fatigando. Nota-se isto em muitas paginas do "S. Bernardo" em que o interesse da historia é muitas vezes suffocado na aridez da phrase, em que a sobriedade exagera-se em seccura, os dialogos tornam-se cortantes e rapidos como os de drama, e os

${ }^{179}$ Criar. 
personagens por isto mesmo acabam mais importantes do que as idéas que elles exprimem. $\mathrm{O}$ romance transmuda-se em drama; a idéa extingue-se na acção. Mas tudo ainda o preconcebido horror da phrase, o escrupulo quasi morbido da acção commum ou do detalhe banal que leva o autor a essas restricções voluntarias, a essa pressão quasi de violencia sobre os primeiros impulsos da sua inspiração. E dizemos assim pelo que ha no livro de intensamente forte e raro como expressão da idéa e de talento. Como expressão do gosto. Há paginas em "S. Bernardo" que não descoram ao lado das melhores paginas dos nossos romances brasileiros, e scenas que sangram de vida como aquella em que elle nos descreve o ciume de Paulo Honorio.

A historia do "S. Bernardo" e facil de resumir: Paulo Honorio, o heroe do romance, é um sujeito que sente logo de menino que a vida é dura, e se endurece para vencel-a. Tudo que é escrupulo de consciencia, sympahias humanas, dengues de coração elle abafa cynicamente debaixo de sua paixão de fortuna. A sua vida sentimental é uma explosão brutal de egoismo que leva quasi ás fronteiras do crime. A mulher que elle escolheu para sua companheira, de um genio delicado e nobre, é a sua ultima e grande victima, cuja felicidade elle detroi ${ }^{180} \mathrm{com}$ a volupia canina do seu ciume.

E o curioso de tudo é que é um typo verdadeiro. E' que é um homem. E'a historia de uma vida. Mas é um livro cruel e que espanta os leitores sentimentaes. E' um livro terrivelmente sceptico, e que o autor o estreita muitas vezes num estylo de faca de ponta, de secco e agudo. Mas é um livro de verdade. E por isto Paulo Honorio subsiste como homem atravez de toda a sua sanha de animal. Elle sente, este bruto; elle é sensivel á paisagem, este monstro.

E' uma das passagens encantadoras do livro aquella em que o autor nos mostra Paulo Honorio, da torre da sua igreja, olhando as terras de S. Bernardo, as suas terras: "Levantava a cabeça - e o horizonte compunha-se de telhas, argamassa, lambrequis. Mais para cima campo, serra, nuvens.

O capim gordura tinha virado gramma, e os bois que pastavam nelle eram como brinquedos de celluloide. O algodoal galgava collinas, descia, tornava a mostrar-se mais longe, desbotado. Numa clareira da mata escura, quasi negra, desmaiavam na sombra figurinhas de lenhadores.

Uma coruja gritava. E Marciano surgia de esconderijos cheios de trevas, o pichaim branco de teias de aranha".

E' apenas um trecho de um dos descriptivos rapidos, mas de uma cor incisiva que tem o livro.

"S. Bernardo" é um livro mais introspectivo; é portanto um livro pouco exterior, onde de raro em raro é que surge uma paysagem, um pedaço de natureza, e quando surge é sempre para dar maior relevo ao elemento humano que é o elemento predominante do livro; mas o pedaço de natureza que mostra é sempre cheio de cor e vida, sem espalhafato.

Mas não é somente pela idéa, pela intensidade macabra do enredo, que o livro "S. Bernardo" é ainda um livro que impõe á critica; é ainda mais pela verdade dos carcteres que nelle se representam, e pela linguagem rica de idiotismos, de locuções populares de um sabor delicioso, e que veem não como em parada de pittoresco, mas sempre a seu tempo, e conformando-se ás situações dos personagens.

Em summa, "S. Bernardo" é um livro, ta ${ }^{181}$ meu vêr, que pode reclamar o seu logar de honra ao lado dessa serie (sic) de romances que tanto tem enriquecido nestes ultimos annos a nossa literatura nacional.

\footnotetext{
${ }^{180}$ Possível erro tipográfico: "destroi".

${ }^{181}$ Erro tipográfico: certamente "a meu ver" ou "tal o meu ver".
} 
S. Bernardo e o cabo da faca, Revista Acadêmica, n. 9, p. 1, 01/1935 ${ }^{182}$

Carlos Lacerda

Os homens têm esbarrado constantemente num dilema excessivamente literario, por isso artificioso: trabalho braçal, brutalidade - trabalho intelectual, sensibilidade.

No entanto já deviamos todos saber que o dilema é outro, que não se espreme nessa estreitesa, e vê mais longe: do lado dos exploradores, embotamento da sensibilidade - do lado dos explorados, expansão dessa sensibilidade.

Bem sabemos que um camponês ou um estivador possúem uma reserva inesgotavel de instinto ainda não afinado no diapasão das conveniencias. Conhecemos academicos, literatos enriquecidos que se perdem em nevoeiros de falsa sensibilidade, como é o caso de Ribeiro Couto, sensibilidade que sôa como moéda falsa, e se exercitam em organizar tempestades conseguidas como as do teatro: efeitos de luz, carpintaria, truques. E' que os exploradores - e os que se colocam a seu serviço - repousam na gorda placidês das digestões faceis e apenas se esforçam no sentido de perpetuar, sob novas fórmas, essa exploração. $\mathrm{O}$ que para os intelectuais que servem á burguezia resulta bem facil, devido ao auxilio que lhe prestam a religião, a policia, todo o aparêlho estatal burguês, criando conluios, espécie de combinações em que uns ficam do lado do cabo, outros do lado da faca...

E' certo que entre nós, onde as condições objetivas estavam passando além das nossas possibilidades de luta, o contraste não estava perfeitamente determinado, e frequentemente assistiamos ao espetáculo de uma extrema confusão, na qual andavamos todos metidos, onde tomavamos gato por lebre e os homens, por falarem em Lenine, pareciam revolucionarios. Agora, que nem feliz nem infelizmente, apenas como consequencia logica da estreita correlação entre a combatividade das massas e a acentuação, da crise, atingindo o plano mais elevado da luta de classes, essa "confusão suspeita" se desmancha, de um Gilberto Amado, que podia dizer impunemente que "no mundo não ha mais lugar para os liberais" sem que isso implicasse em definição de atitudes, a burguesia exige, apontando-lhe um emprego ao peito, que êle se coloque abertamente ao lado de um dos dois contendores.

E o "pensador", como nos costumámos a chamá-lo, diante da intimidação dos cargos, optou pelo campo dos exploradores, onde gosa dos favores divinos. Mas isso foi um parentêsis.

Do lado dos exploradores a sensibilidade está constantemente acêsa, alerta pelas dôres da vida.

Por isso é que com êles está a vida, as possibilidades da vida. Por isso é que a êles cumprirá defender a cultura que o fascismo destróe.

Assim como se pretende mascarar a luta de classes com a mistificação da luta de raças, da luta de idades, (arianos e não arianos, velha geração e nova geração), tambem existe outra fórma de mistificação: a luta de sensibilidades, de onde sáe, safadamente, a tal "teoría das elítes".

Um dos casos mais emocionantes desse embotamento de sensibilidade, embotamento manhoso provocado de propósito pela propria necessidade de justificar a exploração - ou pelo menos esquecê-la para melhor aproveitar-se dela - está o do fazendeiro Paulo Honorio, homem que GRACILIANO RAMOS apresenta no seu recente livro "SÃO BERNARDO".

Sabemos como o fazendeiro recolhe as migalhas da sua capacidade de compreensão humana para distribuí-las, em parcas porções, pela familia, na qual êle vê a continuadora do seu poderio. E' ainda a noção enraizada nêle da propriedade privada...

\footnotetext{
${ }^{182}$ Artigo localizado no acervo de revistas da Fundação Casa de Rui Barbosa, Rio de Janeiro. Pode ser encontrado também no acervo do IEB, em Fortuna Crítica, Acervo Graciliano Ramos.
} 
Sabemos tambem como essa criatura se deshumaniza, justificando crueldades, roubos, tocais, e principalmente - o que é mais revoltante - essa miséria sem contornos dos colonos, miséria estabelecida, esmagadora, que cresta no berço a capacidade de desejar melhoria, que se eterniza num descontentamento indefinido, num malestar impreciso, como o do Honorio que JORGE AMADO botou no "CACAU".

(No "SÃO BERNARDO” a noção de familia continuadora desaparece justamente porque Paulo Honorio sente que a mulher foge ás suas concepções exclusivistas).

Esse tipo do fazendeiro que criou, por um instinto elementar de auto-defesa, uma casca espêssa entre a miséria de que êle vive e a riquêsa da sua vida interior, terminando por embotar a capacidade de sentir o mundo, é o grande valor do livro "SÃO BERNARDO". Enche todo o livro e o domina por completo.

Não ha cinismo na auto-biografia do fazendeiro. Há uma perda completa de humanidade. $\mathrm{O}$ que ali - excetuando-se onde GRACILIANO RAMOS não resiste e méte o bedêlho - é a historia do explorador que venceu tudo, venceu a si próprio, anulando os arrancos de si contra si mesmo. O caso sentimental do livro exprime êsse estado de deshumanização da mesma fórma que a maneira fria pela qual êle calcula a posse de novas terras ou a eliminação de um desaféto. $O$ desperdicio de que êle dá provas quando espesinha $o$ que poderia ter sido um amor de encher a vida, é a demonstração de sua incapacidade de viver uma vida verdadeira. Com êle sucedeu o que sucéde a todos os seus iguais: a vida baseou-se no lucro obtido pela exploração do trabalho alheio. Só assim, e por isso, êle vive.

Quando a revolução vier, encontrará um sistêma para destruir. Não encontrará homens, porque esses, dos da classe dominante, já se dissolveram na lama de si mesmos. Terá apenas a tarefa - grave e grande tarefa - de despertar nos que eram oprimidos, as forças que lá estão latentes, o que represnta ${ }^{183}$ uma aplicação do método socrático: acordar o que está dormindo dentro de nós.

GRACILIANO RAMOS ficará como um dos romancistas que melhor pudéram sentir esse desabamento do mundo bichado. O ambiente chatinho, sordidosinho, dos lugarejos, em que as grandes ambições se estiolam quando a sêca queima as colheitas, e se faz falar da vida alheia um programa para a vida, está nos livros desse homem.

O que havia de excessivamente Machado de Assis, isto é, excessivamente decalcado no molde frio e interesseiro do burocrata que teme descarnar o arcabouço da organização social vigente para não perturbar a serenidade da vidinha, no romance "CAHETÉS", perdeu a sua rigidês de pura mecánica literária no "SÃO BERNARDO". Aí tudo está quente, pulando nas mãos do romancista, pronto para saltar e ganhar mundo, impulsionado pela força da verdade que encerra.

Si algumas restrições se pode fazer a GRACILIANO RAMOS, estas se limitam a duas, a primeira das quais é puramente de técnica de estílo, logo, desimportante: a sua maneira se revéla, se desmascara excessivamente, mostrando a cada passo, no caminho do livro, a marca dos passos do autor. Por isso mesmo o fim do "SÃO BERNARDO", em que a derrocada de Paulo Honorio se parece com a quéda do Carlinhos de Mélo, o rapaz do "BANGUÊ", este ganha daquêle (sic) em intensidade.

A segunda restrição é mais séria: não ha no livro, tão preocupado em revelar o lado do cabo, a vida dos opressores, uma preocupação ao menos equivalente pelo lado do gume, a vida dos oprimidos.

A isso se poderá responder, com grande razão, que se pode servir aos oprimidos, desnudando, com gestos decididos, a vida pôdre dos opressores.

${ }^{183}$ Erro tipográfico: "representa". 
Nesse mistér de recensear os livros que vão aparecendo, ás vezes recebemos surpresas ótimas. Lá vem, em meio de um monte de volumes incaracteristicos ou insignificantes, um belo e forte trabalho, que nos interessa e, não raro, nos encanta. E um tal encontro compensa-nos do esforço que fizeram-nos com o exame e a leitura de duzias de outros volumes sem valor nem expressão. Estou, agora, diante de um caso desses. Ha, entre os livros de ficção, publicados no ano passado, dois de que ainda não tratei, e que, entretanto, têm caráter, côr e significação. Um dêles é o S. Bernardo, do Sr. Graciliano Ramos; o outro é o Maleita, do Sr. Lucio Cardoso. Deste ultimo, pretendo falar em cronica proxima.

Hoje, quero fazer alguns apontamentos sobre o S. Bernardo.

O romance tem como ambiente um recanto de Viçosa, nas Alagôas. E' ali, no engenho S. Bernardo, que reside Paulo Honorio, homem de cincoenta anos e oitenta e nove quilos. Esse homem, ao chegar ao meio seculo de sua vida, resolve contar a sua historia. E é assim que nasce o romance.

Paulo Honorio não conhece pai nem mãe; sua certidão de batismo apenas menciona padrinhos. Ele viveu na miseria, em criança, apanhando da velha Margarida e de um cégo. Foi trabalhador do eito, andou vendendo coisas, tomando dinheiro emprestado. Embaçou os outros, iludiu-os, roubou-os... Enriqueceu e, com as suas traficancias, comprou o S. Bernardo, onde outrora fóra miseravel e humilhado. Prospero, rico, Paulo Honorio procurou uma mulher para casar: encontrou Magdalena, professora publica. Era um anjo, e êle poderia ter sido muito feliz com ela. Mas deixou-se dominar por um ciume atroz. Maltratou-a, sem piedade, sujeitou-a a todas as injustiças, até que Magdalena se suicidou.

Eis o essencial do romance. E' muito simples a arquitetura que aí achamos. Mas esse desenho sobrio e quasi rudimentar é apenas um fundo de pano. Em outros planos, vemos a paisagem, a côr do ambiente que o romance pinta. E são essas as qualidades que interessam e prendem o leitor deste livro.

Ha figuras e quadros de segundo plano, que são muito caracteristicos. D. Gloria, tão dedicada e tão modesta; seu Ribeiro, o grada-livros, sempre no seu canto, fazendo as suas escritas; e mais o Casemiro Lopes, o doutor Magalhães, o Padilha.

A verdade é que o Sr. Graciliano Ramos tem, no seu livro, passagens, episodios, que me parecem magistrais. O capitulo XIX é umas dessas passagens. Magdalena morreu e Paulo Honorio a evoca. Em sua memoria, dispersa, vaga e doentia, as coisas se baralham, complicam, difundem. De tal maneira que êle proprio acaba por confundir o que seja a sua imaginação e o que seja a realidade. Essa superposição de planos dá um efeito de muita comoção e que é dificilimo de se obter.

No romance vemos tambem o ambiente de pequenas intrigas das cidades do interior brasileiro, cheias de competições politicas, obedecendo a chefes deshonestos e torpes. Em tais meios, os representantes da policia e da justiça podem ser tomados como verdadeiros indices da mentalidade geral. E aqui achamos esses indices muito bem apresentados.

Quanto ao estilo do Sr. Graciliano Ramos é cheio de expressões e palavras muito de uso na região de que êle trata. E' facil anotar algumas dessas expressões e palavras: fundurço, abrequei a Germana, S. Bernardo não vale o que um periquito róe, pinoia, bater as botas, estava parida por êle, na taboa da venta, pegar no pesado. Eis uma pagina do livro, para amostra da linguagem: "O Dr. Sampaio comprou-me uma boiada, e na hora da onça beber agua deu-me com o cotovelo, ficou palitando os dentes. Andei, virei, mexi, procurei empenhos - e êle duro como beíra de sino. Chorei as minhas desgraças: tinha obrigações em penca, aquilo não era trato, e tal, enfim, etc. O safado do velhaco, turuna, homem de facão 
grande no municipio dêle, passou-me um esbregue. Não desanimei: escolhi uns rapazes em Cancalancó e quando o doutor ia para a fazenda, caí-lhe em cima, de supetão. Amarrei-o, meti-me com êle a capoeira, estraguei-lhe o couro nos espinhos dos mandacarus, guipás, alastrados e rabos de raposa.

- Vamos vêr quem tem roupa na mochila. Agora eu lhe mostro com quantos páus se faz uma canoa".

E' um estilo um pouco brabo, como se vê; estilo com gosto das frutas asperas do sertão do Nordeste.

Mas estou certo de que é este o principal interesse que o leitor carioca ha de encontrar no livro do Sr. Graciliano Ramos.

Egoísmo, Folha de Minas, 17/01/1935

\section{Oscar Mendes}

No seu primeiro romance, Caetés, que a critica em geral, recebeu bem, traçara o sr. Graciliano Ramos, com minucia e argudeza de observação, um quadro realista da vida nas pequenas cidades. Romance de costumes, nele vivia uma coleção de sêres mesquinhos, mediocres, enredando-se, á de ideais e de ocupações úteis, nos fios peganhentos das suas proprias intrigas.

Neste segundo livro, conquanto o ambiente seja ainda o mesmo: o do interior, com a sua vida monótona e limitada, não se esboça apenas a comedia pitoresca da vida, com suas intriguinhas de entremês. Ha aqui um drama de caracteres. Ou melhor, a análise duma paixão viça na terra sêca dum coração egoista, e se alastra e avassala.

Se em Caetés, não deu o A. preferencias ou tratou com carinhos especiais os ridiculos herois de sua história, em S. Bernardo esculpiu, com energia e expressão, a figura impressionante, mesmo na sua miseria moral e na sua decadencia, desse Paulo Honorio, tipo bem vivo e real, do mandão de comarca, do senhor de engenho tosco, abutalhado e despótico, cuja vontade dominadora pretende quebrar todas as resistencia, todas as outras vontades que ousem se rebelar contra a sua.

E o drama psicológico que o transforma num canhestro memorialista, enquanto a decadencia de seu engenho se vai acentuado, é justamente o de não haver essa sua vontade tiranica encontrado outras vontades bem rijas que travassem combate contra os seus impetos de bruto e de mandão.

No começo de sua vida, teve que lutar, feio e forte, contra inimigos e rivais. Grangeados a prosperidade e o poder, a sua fôrça principiou a se gastar no vasio, porque os outros se retraiam na estrategia cansativa das retiradas. Os filtros venenosos das paixões sem açaimo completaram a derrocada.

E’ o livro, pois, a história de uma decandencia. Não fugiu o A. á moda vigente. Os fracassos, as minas, as degradações, os homens abúlicos e falhados, as mulheres sem virtude, os vicios e torpezas de uma sociedade em decomposição, eis os temas e figuras prediletos, não sómente da nossa literatura, mas da universal. Comprovemos, apenas, o facto, sem estudar-lhe os erros de visão.

Seguindo, ainda, o dernier cri do figurino literario do momento, pespegou o sr. Graciliano Ramos no seu livro alguns palavrões obscenos. Mas inteligente como é, coibiu-se em tempo.

Não quis tambem transformar o seu romance em boletim de propaganda socialista, com cabras de engenho, liricos e lidos em Marx, a vociferar versiculos lenineanos e a prophetizar miragens pradisiacas. Um dos artificialismos do seu livro é mesmo, essa 
Madalena, esposa de Paulo Honorio, normalista letrada e escritora (contraste muito acentuado com a rudeza do marido $\left({ }^{184}\right.$, a conversar reformas sociais com o cretinizado Padilha, professor de primeiras letras no engenho.

Mas esses ensaios de propaganda reformista não vão adiante. O A. pára em tempo. E não sei se por maliciosa ironia (acredito muito na malicia sutil do sr. Graciliano Ramos), o tipo escolhido pelo A. para pregar aos cabras do engenho idéas de reivindicações sociais, é o ridiculo Padilha, desfibrado e medíocre, que, apesar de haver sido espoliado por Paulo Honorio, vive ás suas sopas, roendo um magro ordenado, para ensinar a ler, a escrever e a contar, á garotada bronca do engenho.

Aliás, a lição social que pula vivamente do livro é um fenomeno quotidiano, para qual me chamou ha pouco a atenção um amigo, a proposito do Marreira, do Banguê de José Lins do Rego, fenomeno esse que os senhores comunistas não gostam de verificar e sobre o qual não querem discutir: o da transformação do proletario quando no poder.

Os peores e mais tiranicos patrões são operarios saidos de sua classe. Paulo Honorio, que foi guia de cego, quando chega a senhor de engenho, nem compreende que haja necessidade de ensinar a ler á gente da qual viera. Manda e desmanda. E' o senhor.

Dir-se-á talvez que, com a abolição das classes, o fenomeno desaparecerá e que, ao atingir-se o comunismo puro, ter-se-á a paz idilica das Arcadias classicas. Mas isto é ainda para o futuro. Por enquanto, observemos os Paulo Honorio e os Marreira vivendo a sua vida.

E a vida de Paulo Honorio é uma terrivel lição, para os que fazem do seu eu um Deus dominador. Sua história é o drama do individualismo, do egoismo cégo, que vae semeando em torno de si os germes mortiferos, os elementos de dissolução que acabam por vitimar o seu proprio criador.

Amoral e egoista, Paulo Honorio é uma fôrça céga e bruta, levando de vencida todos os obstaculos, na garantia do proprio bem estar. Sua mocidade se inicia pelo crime, quando, fere, por ciume um rival feliz. E' pelo crime ainda que suplanta os seus competidores na posse das terras do engenho S. Bernardo, que arrancara, com ardis e coacções, das mãos ineptas do desvirilisado Padilha.

E' uma fôrça da natureza que no seu impeto, vai ${ }^{185}$ fazendo o bem e o mal instinctivo e arrogante, não admite grandezas em torno de si. Domina-as, quando não as destroi. Cercamn'o ${ }^{186}$ falhados e abúlicos. Elle é o dono, o senhor.

No matagal dessa alma rispida, ha, porem, clareiras humanas, se bem que abertas pelo seu viceral egoismo . Sempre impetuoso, um dia, sem amor nem interesse, resolve casarse.

A escolhida para sua esposa, forma com elle impressionante contraste. E' a professora da localidade proxima a S. Bernardo. Viera da pobreza. Estudara á custa de sacrificios dolorosissimos de sua tia D. Gloria. Passara privações. Aos vinte e sete anos era apenas professora publica, a cento e oitenta mil réis por mês. Literata. Loura e franzina, como uma boneca.

Faz-se esse casamento sem amor. Aquela mulherzinha delicada e sonhadora vai enfeitar a casa agreste de Paulo Honorio. A sua figura graciosa acentúa, em vincado antagonismo, a fôrça rústica de Paulo Honorio, grosseirão e feio, com a sua cara tisnada de sol, as suas sobrancelhas espessas e intonsas, as suas mãos grossas e peludas, o seu vocabulario brutal e torpe.

O A. não nos conta o que se passa na alma de Madalena. Tendo adotado a tecnica artificial de fazer o proprio Paulo Honorio, rude e sem letras, contar o seu drama, nada nos diz

\footnotetext{
${ }^{184}$ Erro tipográfico: o sinal de parêntesis foi transcrito tal qual no original.

${ }^{185}$ Caso de adoção de duas variantes: "vae" e "vai".

${ }^{186}$ Padrão ortográfico de pronominalização verbal desconhecida.
} 
dos sofrimentos morais, das esperanças irrealizaveis, das desilusões desesperadoras, da imensa tragédia que se desencadeou na alma delicada de Madalena.

O drama desse casamento desigual sobrevém em pouco tempo. As pequenas desinteligencias da vida conjugal se avolumam, se envenenam, vão fermentar. Nem o nascimento de um filho consegue impedir a marcha fatal da tragedia (sic)

Não sei porque não quis o A. aproveitar o rico elemento humano trazido ao drama de seu livro pelo nascimento desse menino. A sua heroína é inhumana. A maternidade não a feminiliza. No naufragio de sua vida conjugal, ela ${ }^{187}$ fica isolada, sem apoio, sem reações, sem vibrações humanas, como uma folha sêca que os ventos furiosos arrastam nos seus vórtices, para todos os quadrantes. Ha qualquer cousa de vago, de inconsistente, de espectral, nessa mulher que só avulta no livro, quando morre.

Em compensação, a destruidora brutalidade de Paulo Honorio enche o livro. Egoista desde a infancia, acostumado a luctar, sem escolher meios, a procurar sempre o proprio conforto e a propria utilidade, quando o ciume se lhe infiltra no coração, quando a idéa de estar sendo lesado na posse absoluta de sua mulher se lhe crava na mente, a tragedia principia. As diferenças de gostos e caracteres, de educação e ideais, afastam totalmente aquelas duas criaturas.

Se falta então ao livro, pela tecnica adotada, a analise dos estados de dalma de Madalena, avulta entretanto o estudo do processo passional em Paulo Honorio. Aqui as melhores qualidades do romancista do sr. Graciliano Ramos se acentuam. Todas as dúvidas, esperanças, hesitações, explosões, arrependimentos, odios e ternuras, que tumultuam no coração dos ciumentos, são estudados com realismo e segurança.

O A. dá a capacidade de sua arte narrativa e de seu conhecimento da paixão insana na alma de Paulo Honorio. Ha cenas que fixam tenazmente na nossa memoria, como a das noites de insonia de Paulo Honorio roído de ciumes, a contar as horas do tempo longo, emquanto a esposa dorme inocente e sossegadamente.

O episodio que sagra o sr. Graciliano Ramos como um dos nossos melhores romancistas, é o que se desenrola na sacristia da capela do engenho. A explicação terrivel entre os dois esposos se precipita. Paulo Honorio, que encontrára uma pagina de carta escrita pela mulher, sente as suspeitas crescerem. Acusa? ${ }^{188}$ de infidelidade. Mas a atitude serena e decisiva de Madalena desarma-o. A tempestade se desfaz. Conversam. Concordam a cerca das causas daqueles dolorosos desentendimentos. Concertam-se as pazes.

De repente, Madalena começa a falar, como num sonho. Rememora sua vida. Pede a Honorio mais bondade para com os que o cercam. E se despede, triste, mas serena, ordenando o esquecimento para todas aquelas miserias.

Seu suicidio marca o inicio da decadencia de Paulo Honorio, que julgou construir a sua felicidade, com a mesma rudeza e a mesma falta de escrupulos, com que se apossara das terras do Mendonça e do Padilha. Todos o abandonam. Não soubera fazer amigos. Só a fidelidade canina de Caetano Lopes ${ }^{189}$, seu companheiro de aventuras e de crimes, resiste á derrocada.

Sobrevém a perda do prestigio politico. Os inimigos tocaiam o momento propicio para derrubal-o.

E no seu engenho arruinado, já sem estimulos, com saudade e um remorso a torturarthe a alma, Paulo Honorio, o egoista, o grande só, escreve a sua historia, e envelhece, como um enorme tronco desfolhado, que a umidade do tempo vai apodrecendo...

\footnotetext{
${ }^{187}$ Caso de adoção de duas variantes: "elle/ella" e "ele/ela".

${ }^{188}$ Erro tipográfico: "Acusa-a".

189 Descuido do colunista: "Casimiro Lopes".
} 


\section{Octavio Tarquínio de Sousa}

O romance continua a ser em toda parte o genero literario em voga. Parece que o terreno que a poesia perde o romance acrescenta aos seus dominios. Romances de todos os feitios, tudo hoje tende ao romance. O conto e a novella se alongam, se espraiam para serem romances. Tanto é romance a caudal de setecentas, oitocentas e até mil paginas, como a narrativa rapida que se estreita em duzentas.

Morto o romance naturalista, surgiram o romance de analyse, o romance de costumes, o romance provincial, o romance rural, o romance exotico e já agora o romance proletario.

Aqui tambem o mesmo phenomeno se observa. O romance triumpha. E é do Norte que os romancistas affluem, nesse grande cyclo inaugurado pelo sr. José Americo de Almeida com "A Bagaceira", em que o drama humano nas zonas ruraes daquella região vem sendo estudado e fixado sob um angulo antes desconhecido na literatura brasileira. "Menino de Engenho", "Doidinho", e "Bangüê", do sr. José Lins do Rego, "Os Corumbas", do sr. Armando Fonte ${ }^{190}$, "Cacáo" e "Suor", do sr. Jorge Amado, têm agora continuação em "S. Bernardo", do sr. Graciliano Ramos e "Coiteiros" e "O Boqueirão", do sr. José Americo de Almeida.

No regionalismo, no regionalismo nortista, encontra o romance brasileiro uma nova seiva, muito rica, porque em contacto directo com as realidades do meio em que desenvolve a sua acção, servindo-se os romancistas do que viram e observaram, das tradições de familia e logar de origem, das reminiscencias da infancia, da expreiencia pessoal. Ha a força da terra, o halito e a luz das paizagens conhecidas, muito differentes das que resultam apenas do esforço da composição literaria. Ha a vida estreita, mas intensa, das creaturas que são reflexo das que viveram em torno dos autores dos romances.

S. BERNARDO - Graciliano Ramos - Ariel - Editora Ltda. - Rio - 1934.

"S. Bernardo" não tem seguramente a força, a pujança creadora de "Bangüê", que é para mim a mais completa realização do romance no Brasil, nestes ultimos annos. Mas é o livro de um escriptor perfeitamente senhor do seu officio, cujas personagens nada têm de fantoches, vivendo e movendo-se no quadro social ou no ambiente domestico de sua formação, em carne e osso, integradas na condição humana. Nenhum livro é menos "romanfleuve" que "S. Bernardo". Nessas duzentas e dezoito paginas seccas, estrictas, concentradas, o sr. Graciliano Ramos poz apenas o essencial. Grande inimigo do superfluo, do derramado, em "S. Bernardo" não ha nada inutil, não ha tempo perdido. Nenhuma paizagem para enfeitar, nenhum quadro que pudesse ser dispensado.

E' uma parcimonia que póde até parecer avara.

Já alguem notou no sr. Graciliano Ramos affinidades com Machado de Assis. E' verdade. A narrativa despojada de qualquer ornato peculiar a Machado é tambem carcteristica do autor de "S. Bernardo". E penso mesmo que ha por vezes a maneira de Machado de Assis, como, por exemplo, no final no capitulo XIII: "Essa conversa, é claro, não saiu de cabo a rabo como está no papel. Houve suspensões, repetições, malentendidos, incongruencias, naturaes quando a gente fala sem pensar que aquillo vae ser lido. Reproduzo o que julgo interessante. Suprimi diversas passagens, modifiquei outras. O discurso que atirei no mocinho do rubi, por exemplo, foi mais energico e mais extenso que as linhas cochas que ahi estão. A parte referente á enxaqueca de D. Gloria (e a enxaqueca occupou, sem exaggero, a metade da viagem) virou fumaça..." A continuação, e particularmente a enxaqueca de D. Gloria (até o

\footnotetext{
${ }^{190}$ Amando Fontes.
} 
nome), tudo isso tem o cunho machadista. Mas trata-se certamente de uma mera coincidencia ou influencia de leitura, e nunca de imitação. Aliás, o sr. Graciliano Ramos apresenta as suas creaturas numa luz muito mais crua, em contornos muito mais nitidos, sem os esbatidos, as sombras, as reticencias do autor de D. Casmurro, num processo que é seu e que só lembrara o daquelle pela simplicidade que ambos possuem.

Esse Paulo Honorio, figura central do livro, que faz a narrativa na primeira pessoa, não parece capaz, literariamente, de escrevel-o. E' empresa muito acima de suas possibilidades, a julgal-o pelo que elle mesmo nos diz do cultivo de sua intelligencia. Mas o certo é que Paulo Honorio não é uma creatura vulgar. Sua natureza é complexa, nessa mistura de maldade sem remorsos, de ambição fria, da capacidade raciocinada com que se apossou da propriedade do Padilha, da impassibilidade, da ausencia de escrupulos até a suppressão violenta de Mendonça e ao mesmo tempo da necessidade de proteger as filhas solteiras deste e da ternura por Margarida, a preta velha que o acolhera quando criança.

Nessa contradição está a humanidade da figura, a sua marca de authenticidade.

Toda a vida de Paulo Honorio, no trecho em que a conhecemos, mostra-o numa realidade tangivel. Depois do casamento, desse casamento mal arrumado, com uma mulher que nunca o acceitaria e que elle tambem nunca poderia entender, quando o ciume o empolga, Paulo Honorio aprofunda a sua vida interior, ostenta dons de introspecção surprehendentes e chega a um verdadeiro desdobramento de personalidade. O ciume afina-o, dá-lhe um sentido novo. Já Magdalena não tem a mesma nitidez de contornos. A luz crua que bate em cheio sobre Paulo Honorio alcança-a apenas pela metade. O leitor acaba o livro sem saber ao certo o que é essa professora publica. Será talvez porque a narrativa é feita por Paulo Honorio e é através delle que ella se projecta na nossa retina.

D. Gloria, Padilha, Casimiro Lopes, cada um no seu logar, dentro da sua orbita, vivendo da verdade.

\section{"S. Bernardo" e a Politica Litteraria, Boletim de Ariel, 02/935}

\section{Jorge Amado}

O sr. Augusto Frederico Schmidt num artigo no "Diario de Noticias" sobre $S$. Bernardo $^{191}$, segundo romance de Graciliano Ramos, tratou o livro com evidente má vontade. O motivo desta má vontade não sei. O que não quero acreditar é que em vez de má vontade fossem erros tolos de interpretação do livro do romancista alagoano. O sr. Augusto Frederico Schmidt após se rasgar em elogios aos romances apparecidos este anno ${ }^{192}$ trata dos dois ultimos: S. Bernardo e Vertigem. Sobre este ultimo não disse nada de interessante, podendo dizer muita coisa. Mas sobre o primeiro foi peor: tratou o livro que é, não póde restar a ninguem a minima duvida, um dos maiores romances surgidos por aqui, romance á altura de Banguê e Os Corumbas e melhor que qualquer outro, como o volume de um estreante a quem não é justo desanimar. Fiquei pensando nos motivos desta attitude e não os encontrei.

Mas num rapido inquerito que fiz nos meios intellectuais colhi varias opiniões que para aqui transporto para que o publico, principalmente o do interior, tenha idéa de quanta politica, e mesquinha política, ha na cidade das lettras. Os informes que passo ao publico são de valor, não só porque me foram dados por pessoas que merecem fé, como porque qualquer delles póde exprimir a verdade. Vejamos. Disse-me a primeira pessoa com quem conversei: -

\footnotetext{
${ }^{191}$ Referente ao artigo de 16/12/34 transcrito neste trabalho.

${ }^{192}$ Conforme nos indica este período, muito provavelmente este artigo, resposta de Jorge Amado a Schmidt, tenha sido escrito em dezembro de 34 , contudo publicado em fevereiro de 35.
} 
“O Schmidt é um velho inimigo do Graciliano. Inimigo gratuito. Já com o primeiro livro do Graciliano o Schmidt pintou o diabo. Prendeu o livro quatro annos na sua casa editora. O livro sahiu quando estava velho e não agradava ao Graciliano. O poeta pretendia fazer o mesmo com o S. Bernardo. Matar o livro, envelhecendo-o nas suas gavetas. Mas o Graciliano não lhe deu o livro e o Schmidt pensou que o destruiria com aquelle artigo. Foi esta a razão.”

Opinião de outro litterato: - "O Schmidt queria afastar o livro de Graciliano da concorrencia a um premio e sendo vaidoso em excesso pensou que com aquelle artigo afastaria de vez o Graciliano de certos cinco contos".

Disse o terceiro litterato: - "Foi por estes dois motivos e mais um terceiro. E' que Octavio de Faria ainda não escrevera sobre o livro e o Schmidt tinha medo de elogiar sem saber se o Octavio elogiaria. Telephonou repetidas vezes para o Octavio, mas não o encontrou em casa. Então fez aquelle artigo."

Opinião de alguem que conhece muito o Schmidt: - "E' que o Schmidt não leu o livro. E' um velho costume delle. Escreve sobre os livros sem os ter lido. Assim fez um prefacio para o Paiz do Carnaval, assim escreveu em Litteratura, sob pseudonimo, um artigo sobre Os Corumbas, assim fez uma faixa para o Maleita."

Falou um romancista: - "E' que o Schmidt anda triste e abatido."

Passo estas informações ao publico. Fica provado que o poeta Augusto Frederico Schmidt escreveu um artigo sobre $S$. Bernardo por motivos de politica litteraria.

Eu sou dos que acreditam que o artigo do sr. Augusto Frederico Schmidt possa sequer fazer o livro de Graciliano Ramos perder um unico leitor. Mas, se trouxe estas coisinhas desagradaveis para aqui, é que fiquei, como muita gente, revolado ${ }^{193}$ com a má vontade do alludido artigo.

Revoltado porque o S. Bernardo é, realmente, um dos grandes romances do Brasil. Romance de alguem que é hoje o nosso maior romancista. Em verdade temos alguem que melhor que elle sabe armar o arcabouço de um romance: Oswald de Andrade. Porém, Graciliano já attingiu uma seccura, uma densidade humana tal, que me parece será este alagoano o primeiro brasileiro que passará da simples emoção para a revolta. Em S. Bernardo ainda é emoção, mas tão grande emoção, tamanha força dramatica, que em certos momentos (naquelles em que se volta para a vida dos trabalhadores ruraes) se approxima muito da revolta. Isto e a sua seccura, o dominio que o escriptor tem sobre este gosto muito brasileiro de se espalhar, de se derramar em paginas de soluções, collocam este romancista numa situação de ser num futuro proximo o romancista dos trabalhadores ruraes do nordeste, dos operarios das cidades, conseguindo dar aos seus volumes um tom épico de revolta, escrevendo livros que não bulam apenas com os nervos dos leitores.

Neste $S$. Bernardo não sei se a maior coisa é o ciume, o drama daquelle Paulo Honorio e da professora sensivel, ou serão as pinceladas rapidas sobre o drama do trabalhador rural. E' verdade que Graciliano Ramos passa de leve sobre este drama para fixar fortemente o de Paulo Honorio com seu casamento. Porém estas rapidas pinceladas dão uma idéa perfeita da miseria em que vivem os trabalhadores do campo.

O romance de Paulo Honorio é tão intensamente doloroso que machuca o leitor. Agita os nervos todos da gente. A seccura do romancista muito concorre para isso, pois não abre uma clareira no tom escuro do romance. Nem os almoços, as festas, nem mesmo o começo da paixão de Paulo Honorio, nada neste livro, lembra lyrismo, lembra paginas commovidas e fáceis de fazer. E' tudo secco, duro, cruel. O romancista não se afasta da linha que traçou. Não que Graciliano Ramos esteja presente nos seus personagens. Possivelmente

\footnotetext{
${ }^{193}$ Erro tipográfico: "revoltado".
} 
elle está presente no romance. Porém, não nos personagens. Estes se locomovem por conta propria, agem como querem e se são seccos e ruins é que assim os fez as condições de vida do tragico nordeste. No emtanto a professora é boa e até meio litteratta ${ }^{194}$. E apezar disto onde estão as paginas largadas, lamurientas, que os romancistas fariam sobre ella? A seccura do romancista é a mesma. No emtanto o leitor sente a immensa differença que vae de Paulo Honorio a Magdalena.

Outra coisa a elogiar no nosso maior romancista: a força das suas figuras secundarias. Aquelle negro cão de fila de Paulo Honorio é uma figura admiravel. A tia de Magdalena tambem. São figuras que apparecem á margem do drama do livro mas ficam vivendo, marcados pelo maior creador de vida e typos que ha no Brasil hoje.

"S. Bernardo" - Ariel Editora, Folha de Minas, 03/03/1935

Antonio Favernard ${ }^{195}$

Não li "Cahetés", romance de estréa de Gratuliano ${ }^{196}$ Ramos. Por presentir, nelle, mais uma dóse do que, então, me saturava: o "populismo" litterario. Em compensação, rendome, agora, ao seu "S. Bernardo". Com restricções, porém. Porque, neste, ha passagens sujas de palavrões dispensaveis, e porque ainda não me conformei em acatar o palavrão como motivo de arte.

Fóra disso, tudo nesta historia do homem e da terra (elle quasi sem cultura, ella quasi sem civilização), merece o applauso vehemente e o respeito intellectual devido ás obras de alto e legitimo valor.

Formidavel o seu Paulo Honorio!

Figura shakespeareana, talhada em acapú! Estereotypo da symbiose physico-moral da senzala com a da casa grande! Exemplo do boyardo brasileiro, egresso da barbaria, anachronico, mas mantido pelo nosso estagio sociogenico, maximé em certas zonal do sertão!

Vindo da miseria; sem nome e sem ninguem; criminoso de sangue na adolescencia; aprendendo a ler na cadeia, por uma biblia; enriquecendo em latifundios pelo roubo para não ser roubado, e pelo assassinio para não ser assassinado; rude a ponto de confundir alma e corpo num só bolo amorpho e vil; quasi besta humana, esse alagôano retratado em téla deal, pertence ao numero dos personagens litterarios que não se olvidam.

Merece mais que estes alinhavos aligeros.

Está muito além de tantos sucessos bonbasticos... E, só por si, faz com que se considere "S. Bernardo" um grande livro, e Gratuliano Ramos um grande autor.

Gratuliano Ramos - conservo este nome, conserve-o quem me lêr! Elle ha de ser o Dostoiewsky tropical.

\footnotetext{
${ }^{194}$ Variante ou erro tipográfico de "litterato": cf. o início do terceiro parágrafo.

195 As referências de data e do nome do jornal estão datilografadas ao fim da folha em que se encontra o recorte. O nome do articulista foi escrito por próprio punho de Graciliano, bem como a cidade do autor, Belém do Pará. ${ }^{196}$ Não se trata de erro tipográfico. Cf. In: RAMOS, Graciliano. Cartas, Rio de Janeiro: Ed. Record, 1992. (Cf. p. 145)
} 
O sr. Gracilliano Ramos vem de publicar um romance regional intitulado "S. Bernard" (sic). O livro contendo duzentas e poucas paginas, é uma especie de biografia em que o Autor, que representa o principal personagem, procura estudar a vida rural alagoana, sintetizada na sua fazenda "S. Bernardo".

Seria, aliás, de admirar si assim não acontecesse, porquanto a atenção dos literatos do país inteiro, no momento que atravessamos, está voltada para o sertão. A Terra absorve o Homem, com os seus problemas reais e variados. E o sr. Graciliano Ramos, espírito moço, não podia deixar de formar á vanguarda do movimento que se alastra, dia a dia, de norte a sul.

O Autor narra a vida de um homem que se fez por si só, lutando com todas as dificuldades, traficando, fazendo tudo para chegar a assenhorear-se de um pedaço de chão que lhe renda mais que o necessario á subsistencia. Para isso, teve que variar nos mais diferentes ramos de negocio, "viajando pelo sertão, negociando com rêdes, gado, ganhando aqui, perdendo ali, marchando no fiado, assinando letras, realizando operações embrulhadissimas". Caracteriza se (sic) o caso real, e todos os que conhecem a vida no nosso hinterland aceitam como veridicas as historias contadas por Paulo Honorio. Além do mais, o Autor sabe imprimir um espírito novo em tudo o que escreve, empregando termos apropriados e conhecidos no falar rústico do sertão.

O livro, em seu conjunto, demonstra como a tenacidade vence todos os obstaculos, por mais que pareça dificil de atingir o fim colimado. Assim, Paulo Honorio torna-se rico, possuidor de uma bela fazenda, criador e agricultor abastado, com cavalos de sela, vacas leiteiras e cabras armados para as eleições. Pouco importa que, para isso, haja feito negocios nada ou pouco honestos. Conseguiu acumular, realizou o seu sonho, os amigos vieram, atraídos pelo dinheiro. O sr. Graciliano Ramos narra isso tudo claramente, sem subterfugios, em linguagem simples e original, que é o principal valor de "S. Bernardo".

Faltava ao ambiente, porém, a graça feminina, e Madalena entrou no romance, para preencher a lacuna. Depois, quando tudo está calmo, quando tudo parece feliz, vem o ciume, e começa a tragedia interior de Paulo Honorio. Aí o romance termina, com o suicidio de Madalena, descrito admiravelmente numa pagina em que mais revela a faculdade de impressionar que possue o sr. Graciliano Ramos.

A leitura de "S. Bernardo", ao mesmo tempo que satisfaz aos que vêm na literatura sertanista uma das preciosas fontes para a criação de uma literatura essencialmente nossa, deixa transparecer, evidencía um mal a que poucos escritores têm fugido e que é, no entanto, uma das principais razões da não expansão das nossas obras de arte.

O sr. Graciliano Ramos escreve bem, tem um estilo agradavel, uma maneira de dizer toda sua. Alguns trechos do seu livro revelam um espirito atilado, um impressionista vigoroso, um narrador de folego. Os capitulos XXX e XXXVI, principalmente o ultimo, em que se sente o remorso corroendo a alma rustica de Paulo Honorio, são paginas autologicas ${ }^{197}$, que elevam sobremaneira o conceito do autor ${ }^{198}$. E' de crêr se que o sr. Graciliano Ramos tenha imaginação bastante para fazer um livro utilisando-se apenas recursos que revelou possuir nesses trechos lapidares de "S. Bernardo".

\footnotetext{
${ }^{197}$ Muito provavelmente "antológicas".

198 Variação do uso do termo autor com minúscula e maiúscula.
} 
No entanto, assim não aconteceu. O autor, como quasi todos os escritores modernos, confundiu, muitas vezes, o baixo calão com a linguagem popular. Daí as passagens inconvenientissimas que se encontram, quasi seguidamente, em "S. Bernardo", de modo a tirar o efeito da sua leitura suave. Varias paginas perdem o seu valor pela intromissão de frases bruscas que fazem a gente ficar pensando terem sido elas insertas ali unicamente para mostrar o espirito de ultra liberdade que domina a moderna literatura brasileira.

E é justamente a incompreensão dessa liberdade, que deveria ser tomada em termos comedidos, o principal fator para o descrédito da nossa literatura. Pensam os escritores novos que romance moderno, e principalmente romance sertanista, deve ter, pelo menos, duas paginas de imoralidades, para que ellas se fixem bem na memoria dos leitores. E dizem, ou pretendem dizer, que assim é que realmente vive o povo, assim é que o povo fala.

Mal sabem eles ${ }^{199}$, porém, que essas passagens muito pouco recomendam as suas obras. E isso é facil de ser demonstrado, porquanto, sendo o romance, ou o conto, em geral uma obra de arte, a sua finalidade é a de procurar não só o belo e o real mas o que existe de interessante e original nesse belo e nesse real. Logo, só se explica o caso crendo-se que os modernos literatos do Brasil acham originalidade digna de ser incluida em um volume que vai passar por centenas de mãos, concorrer para a formação de uma literatura - qualquer frase imbecil pronunciada por um matuto boçal e analfabeto.

O livro do sr. Graciliano Ramos, não ha duvidas, é um volume que contem muitas paginas apreciaveis (sic). O construtor de "S. Bernardo", porém, não soube higienisar o seu livro - e quando dizemos higienisar não é no sentido de fazer do romance um breviario mistico e carola, mas sim um livro que, em todas as suas paginas, honre a literatura sertanista do Brasil ou, pelo menos, procure desfazer a impressão, já bastante arraigada, de que toda obra regional só é perfeita quando encerra capitulos que não possam ser lidos em voz alta ou por pessôas serias.

“Chronica Literária”, Estado de Minas, 17/03/1935

Jayme de Barros

\section{S. Bernardo - Graciliano Ramos - (Ariel - Rio - 1934)}

Não ha duvida nenhuma que estamos deante de um romance admiravel. O heróe do sr. Graciliano Ramos, para justificar a saborosa linguagem do livro, começa explicando por que resolveu elle mesmo escrever sua historia. ${ }^{200}$ Pensou, a principio, numa collaboração colletiva, que falhou. Azevedo Gondim, que apresentou os dois primeiros capitulos, foi um desastre.

- Vá para o inferno, Gondim. Você acanalhou o tróço! Está pernostico, está safado, está idiota. Ha lá ninguem que fale déssa fórma!

Um pouco encabulado, Azevedo Gondim explicou:

- Foi assim que sempre se fez. A literatura é a literatura, seu Paulo. A gente discute, briga, trata de negocios naturalmente, mas arranjar palavras com tinta é outra coisa. Se eu fosse escrever como falo, ninguem me lia.

Esse tem sido o erro dos nossos melhores escriptores. Sua linguagem escripta, artificial e pomposa, différe por completo da linguagem falada. O estylo camoneano, de

\footnotetext{
${ }^{199}$ Uso das duas variantes ortográficas: "elle/ele; ella/ela".

${ }^{200}$ Esse primeiro período do artigo será comentado, de forma irônica, por Graciliano na carta de 03 de abril de 1935 enviada a Heloisa, sua esposa. Ver em RAMOS, Graciliano. Cartas, Rio de Janeiro: Ed. Record, 1992. (Cf. pp. 146-147)
} 
ordem inversa, no qual, segundo velha pilheria, é preciso faro de cão policial para descobrir o sujeito occulto, caracteriza, em prosa e verso, toda a antiga literatura brasileira. Escriptores ha que nos dão a impressão de que escrevem numa lingua desconhecida e morta, tão estranha e differente da realidade é sua fórma de expressão. Separam por completo a linguagem que usam nas conversas daquella em que escrevem.

Lembro-me bem de um facto que define essa mentalidade. Carlos Dias Fernandes acabava de regressar de uma excursão jornalistica aos Estados Unidos e, uma tarde, na redação d'O PAIZ pedi-lhe impressões.

Conservador surprehendente, animador vivo, enthusiasta, o poeta comico começou assim a descripção de Nova York:

- "Nova York" é uma cidade onde o homem apagou os vestigios da natureza. Você não vê a terra, não vê uma flôr, não vê uma planta, não vê arvores. Tudo está coberto por asphalto e de cimento armado. Da natureza, só se descobre o céo. Mas esse céo é formado pelo fumo das fabricas"

Parecia a descripção de Moscou, em um dos romances de Tolstoi.

No dia seguinte, deparo no jornal com longa chronica de Carlos Dias Fernandes. Uma lastima. Escrevendo, elle cegava. No $25^{\circ}$ andar de um arranha-céo, deante da cidade espantosa, Carlos Dias Fernandes não vê senão o estylo, as citações, os classicos latinos: : ${ }^{201}$ Abri o meu Horacio Valemecum..."

Manifestei-lhe, pouco depois, o meu despontamento, e o romancista me respondeu com palavras parecidas com as do Azevedo Gondim, do sr. Graciliano Ramos:

- Ah! Meu caro. Conversar é uma coisa. Escrever é outra. A responsabilidade do que sáe em letra de forma é tremenda.

Mas o Paulo Honorio do sr. Graciliano Ramos não se conformou. Resolveu escrever elle mesmo, e a seu geito, o romance. Infelizmente, em S. Bernardo, houve um erro de techinica: Paulo Honorio não convence ninguem, com seu espirito acanhado, de horizonte curto, sua mentalidade pouco cultivada, de que seria capaz de escrever este livro, que é um dos melhores romances aqui apparecidos nos ultimos tempos. Vê-se logo que quem o escreveu foi mesmo o sr. Graciliano Ramos, e que elle não é Paulo Honorio.

A historia, em estylo simples, directo e facil, principia assim:

"Começo declarando que me chamo Paulo Honorio..."

Parece Eça de Queiroz, em Singularidades de uma rapariga loura: - "Começou por me dizer que seu caso era simples e que se chamava Macário".

Simples suggestão, talvez sem maiores consequencias. Dahi por deante, nem a historia, nem o estylo, têm nada que se pareça com a maneira do autor da Ilustre Casa de Ramires. Se alguma influencia se observa, depois, é de Machado de Assis. Tal como o romancista de Dom Casmurro e das Memorias Posthumas de Braz Cubas, o sr. Graciliano Ramos aboliu o superfluo. Não perde tempo, nem espaço, com descripções e paisagens. Se não chega ao ponto de evitar, como Machado de Assis, que no seu romance appareça uma arvore, a verdade é que S. Bernardo é todo [ilegível] narrativa, dialogo, paisagem humana, psycologia, acção, vida.

O capitulo sobre a conversa com D. Gloria, no trem da Great Western, contém a seguinte resalva:

"Essa conversa, é claro, não sahiu de cabo a rabo como está no papel. Houve suspensões, repetições, mal entendidos, inconcruencias naturaes quando a gente fala sem pensar que aquillo vae ser lido. Reproduzo o que julgo interessante. Suprimi diversas passagens, modifiquei outras. O discurso que atirei no mocinho do rubi, por exemplo, foi mais energico e mais extenso do que as linhas chôchas que ahi estão. A parte referente á enxaqueca

\footnotetext{
${ }^{201}$ Provável erro tipográfico.
} 
de D. Gloria (e a enxaqueca occupou, sem exaggero, metade da viagem) virou fumaça. Cortei igualmente, na cópia, numerosas tolices ditas por mim e por D. Gloria.

Ficaram muitas, as que minhas luzes não alcançaram e as que me pareceram uteis. E' o processo que adopto: extraio dos acontecimentos algumas parcellas; o resto é bagaço."

E, no fim do capitulo: "Vou dividir um capitulo em dois. Realmente o que se segue podia encaixar-se no que procurei expôr antes dessa digressão. Mas não tem duvida, faço um capitulo especial por causa de D. Magdalena".

Mas isto é Machado de Assis!

Vamos deixar de parte a incoherencia de Paulo Honorio, confessando afinal, que se não escreve tudo quanto se fala. A respeito da eliminação do superfluo, escreveu Braz Cubas: "Sabido que reli a carta, antes e depois do almoço, sabido fica que almocei, e só resta dizer que essa refeição foi das mais parcas da minha vida..."

E, mais adeante: "Mas, ou muito me engano, ou acabo de escrever um capitulo inutil". Ou então: "Não: decididamente suprimo este capitulo". E ainda: "Convém intercalar este capitulo entre a primeira oração ${ }^{202}$

“Literatura e Romance”, Diario de Noticias, 31/ 03/1935

Dias da Costa

A leitura do romance $S$. Bernardo do sr. Graciliano Ramos, veiu amenizar a decepção que me produziu a leitura do romance $O$ Boqueirão do sr. José Americo de Almeida.

Ha muito tempo já eu lera A Bagaceira. E, embora achasse nesse livro os typos um tanto falsos, considerando aquelle Lucio um specimen bastante exotico da fauna humana, maculando com conceitos wildeanos a brancura das paredes da casa do engenho paterno e possuido por um amor incompreensivel que o leva ás raias da imbecilidade, culpava de tudo isso a época em que o livro foi escripto e admirava no autor o Messias de uma nova cruzada para a humanização do romance brasileiro, o iniciador de uma estrada que tão brilhantemente foi trilhada depois, principalmente pelos escriptores do Norte.

Agora, porém, depois de já publicados João Miguel, de Rachel de Queiroz, Menino de Engenho, de José Lins do Rego, Cacau, de Jorge Amado, Os Corumbas, de Armando Fontes, etc., a leitura de um romance como $O$ Boqueirão é um salto tão violento para traz que chega a produzir um mal-estar só explicavel com o conto de João do Rio, A sensação do Passado.

E' o que não succede com S. Bernardo.

De Cahetés, primeiro livro do sr. Graciliano Ramos, optimo livro, embora um tanto antiquado, para o novo romance, ha uma evolução salutar, um aperfeiçoamento de techinica, uma segurança na dosagem de emoção que chega ás vezes ao irreprehensivel.

E vemos assim dois romancistas, ambos dispondo de bom material, ambos possuidores dos mesmos conhecimentos literarios, e, ao contrario do que seria de esperar, vê se um evoluindo extraordinariamente no sentido da humanização emquanto o outro involue a ponto de se tornar quasi ilegivel. E' que, emquanto o autor de Boqueirão é antes de tudo um literato, o autor de $S$. Bernardo é mais do que tudo um romancista.

Vejamos os processos de que usam os dois autores.

\footnotetext{
${ }^{202} \mathrm{O}$ artigo termina incompleto. Mas há clara alusão de plágio nos comentários e comparações.
} 
Graciliano Ramos cata os seus personagens, dá-lhes o impulso inicial e deixa que elles se movam por si mesmos. Não toma partido, não concerta, não literatiza, não se intromente. Se um sujeio ${ }^{203}$ é coxo na vida e tem de entrar para o livro, entra, e coxeia por todas as paginas.

José Americo, não. Concebe arbitrariamente os seu typos, constroe-os physicamente ao seu modo, dá-lhes as suas proprias idéas, liga-lhes os cordéis de fantoches, e, assim equipados, bota-os no livro e começa a mexer os dedos para que elles se movam de accordo com sua vontade, emquanto elle banca o ventriloco. E o resultado não póde ser outro. Os bonecos começam a dar saltos grotescos, a falar em linguagem de Ruy Barbosa, a se abraçar com caminhões que transportam materiaes de obras contra a secca e a emittir conceitos netzcheanos, embora estejam em pleno sertão do Brasil, "sob o olhar malicioso dos tropicos".

Tudo vae muito bem quando o leitor é myope. Mas quando não o é e percebe os cordéis e conhece que aquellas palavras correctas vêm dos bastidores, tem a impressão de que está sendo logrado e que, julgando comprar um romance, adquiriu apenas um bilhete para um espetaculo de marionettes.

Senão, vejamos como desfilam deante do leitor os personagens dos dois livros.

Em S. Bernardo, ha quatro mulheres, as mais differentes em tudo, - d. Gloria, Magdalena, Rosa e a preta Margarida. De qualquer uma para qualquer outra vão distancias enormes de côr, de idade, de instrucção, de categoria social, de tudo enfim. Pois bem, apesar dessas distancias ellas cabem todas dentro do romance, agindo e falando, sentindo e soffrendo, cada qual a seu modo naturalmente, sem incoherencias, podendo viver assim no livro, porque assim vivem na vida. Com os homens a mesma coisa. Padilha, Gondim, Marciano, o dr. Magalhães, Paulo Honorio. Grandes abysmos ha entre elles. Abysmos pessoaes, abysmos sociaes. E, no emtanto, vivem juntos, se comprehendem ou não se entendem, brigam, roubam, amam e matam, avançam ou recuam, falam e pensam, - e não se notam os cordéis e não se ouve a voz nasalada que fala detraz do pano. Todos elles, devido aos factores que os cercam e que são os elementos formadores das suas personalidades, fariam cá fóra, num ambiente semelhante, as mesmas coisas que fazem no livro. Sómente uma coisa Paulo Honorio seria incapaz de fazer na vida. Era escrever, como escreve, o seu proprio romance.

E é por isso que, emquanto os personagens de $S$. Bernardo entram logo para o numero dos nossos conhecidos, desses que nos pagam o bonde, que pisam o nosso callo mais estimado ou que nos filam o cigarro ou o aperitivo (sic) os bonecos do Boqueirão não podem sair do livro, onde continuarão inhumanamente a declamar conceitos burilados e a ejacular pedantemente phrases cheias de subtilizas. E lá se ficam. Remo sózinho, se virando para o matto indifferente e orando ao Nordeste, Irma bancando a esphinge "made in Brazil" e repetindo ante a traição do homem a quem ama "boas noittes" charadisticas como a trave que a cerca. Elza, Gracinha e o engenheiro White desconcertando systematicamente o leitor a cada gesto que fazem e a cada palavra que dizem. Nada têm de humanos. São apenas literatizados, no máo sentido do termo.

Talvez haja quem procure justificar a incoherencia dos personagens de Boqueirão com o choque que se dá no livro de duas civilizações antagonicas. Uma super-civilização procurando dominar uma semi-barbaria. Mas o agrupamento não prevalece, porque no $S$. Bernardo tambem ha choque, e talvez mais profundo, pois já existem entre os seus personagens individuos que procuram palavras modernissimas para o Brasil sertão, como seja communismo, luta de classes e materialismo historico. No emtanto, essas palavras não estão mal collocadas. Em ambos os livros a luta de classes está patente, differindo apenas na maneira de apresentação. Num ella se apresenta logica, coherente, honesta. No outro,

${ }^{203}$ Erro tipográfico: "sujeito". 
arbitraria, literaria, artificial. Dahi o desequilibrio. Dahi a differença entre esses dois livros que se apresentam tão antagonicos e que poderiam sair enormente semelhantes. E de onde deviam sair dois grandes romances saiu apenas um romance só e um album de phrases bonitas.

E, emquanto o album é forçado a se restringir á admiração de alguns retardatarios, porque é artificial, o romance penetrará bemfazejamente em todos os espiritos porque é humano.

“Livros nacionaes”, Movimento, 05/1935

Jorge Amado

Nesse segundo livro do sr. Graciliano Ramos, nota-se, inicialmente, um grande progresso sobre o primeiro, ainda muito cheio de Eça de Queiroz. Dêle si póde dizer que está muito cheio do sr. Graciliano Ramos, pois o escritor alagoano, si bem deixe aos seus heróis absoluta liberdade de ação, não se póde afastar do seu livro, talvês devido á sua maneira de romancear.

Descreve o sr. Graciliano Ramos neste volume, a vida de um dos grandes senhores rurais da sua zona. Temos aí um retrato em corpo inteiro de um senhor de fazenda do nordéste, rudimentar e analfabeto, porém com um sentido de propriedade e de classe pouco comum.

Dizer que o tipo está admiravelmente descrito, é inutil. As qualidades de romancista do sr. Graciliano Ramos são por demais conhecidas. Porém, nesta nota, o que eu quero fazer notar é que, devido mesmo a essa descrição da vida e dos ciumes de um senhor rural, aparecem de quando em vês no livro, algumas cênas sôbre a vida dos trabalhadores dessas fazendas do nordéste. E, si bem essas cenas não sejam sinão secundárias no movimento do romance, dão uma bôa medida do que é a vida miseravel daqueles trabalhadores, que continuam tão escravos quanto os negros antes do 13 de Maio. A maneira de romancear do sr. Graciliano Ramos presta-se admiravelmente para tais cênas, pois êle é um escritor absolutamente sêco, sem literatura inutil, sem qualquer exagêro. E no dia em que se dispuzer a fazer o romance daqueles trabalhadores em vês do do seu patrão, nos dará um livro de grande alcance humano e social.

O Patrão em S. Bernardo, Revista Academica, n. 13, pp. 22 e 23, 08/1935 $5^{204}$

Dalcidio Jurandir

Não sei como devo começar minha nota sobre S. Bernardo. O escriptor faz uma camaradagem com a gente de um modo pegajoso como um xodó. Falar dos seus livros é uma difficuldade. É uma surpreza de admiração que anima pra burro. Graciliano creou vigorosamente o seu romance. Tem um logar inesperado e insubstituivel no romance brasileiro. Elle estripa a sua humanidadezinha facil na apparencia mas complexa na estructura. Bichos molles, viscosos, escorregando-se da mão, rachiticos mas entrando no romance á vontade e fica la expostos sem uma nodoa na revelação dos seus caracteres. É uma urdidura impressionante entre as paredes claras, solidas e nuas daquelle estilo que ia dizer

\footnotetext{
${ }^{204}$ Artigo encontrado no acervo de revistas da Fundação Casa de Rui Barbosa, Rio de Janeiro.
} 
stendaliano si não fosse uma comparação idiota como as criticas atuaes de Tristão de Athayde. Soliloquio, agudo. Lembra o velho Machado. Tem a ligação mais directa com o mundo, sem densas complicações psicologicas. Machado de Assis fez os seus personagens á sua semelhança. Graciliano foi feito pelos seus personagens. Vivem elles todos se mordendo e se escapulindo até o fim. Depois a sciencia do dialogo. Saber medir e crear o senso do dialogo no romance. Os typos fallam á vontade, como querem, em carne e osso, com as suas tragédias anonymas e infinitas como a vida, com as contradicções do capitalismo. Graciliano está creando uma pequena Comedia humana. S. Bernardo fixa a historia de um Desastre. Da vida que não era pra ser como aquella de Moreau de Flaubert em outro sentido. Paulo Honorio, no seu abrutalhamento, chega a perceber que a sua vida errou. Não acreditei muito não nessa quasi conversão de Paulo Honorio. O romancista quer dar um castigo de consciencia... Ahi o escriptor ajuda o seu querido personagem no trambolhão dos dias de crise. Teve pena do Paulo Honorio. No fundo já ha a consciencia de uma força a exigir uma feição mais humana aquella realidade compressora. O Sr. José Americo inspira uma revolta que no fim é conciliação. $\mathrm{O}$ flanco do sertão rasgado pelo soffrimento e pela desgraça não póde mais se encher com meias medidas. O açude - eis a salvação do povo, conclue o autor de Boqueirão. Remo assume o papel de ideólogo burguez e crea o hólocausto - um gosadissimo fim dramatico ao desastre.

Paulo Honorio pesa mais na balança das realidades humanas. É mais compacto, mas copioso, mas espalhado na vida com as causas que determinam, a decomposição das classes dominantes. É o patrão. Mais fatal do que a secca. A secca é periodica, o patrão permanente e quanto mais escravisa mais se lhe aumenta a ganancia. Remo é uma allegoria. Paulo Honorio é um homem trazido aos arrastões, pegado com a vida, com muito mais difficuldade de ser estudado e retactado porque o bicho é difficil de amansar. É atirado no meio do romance com o lixo humano dos seus escravos e dos seus comparsas. Patrão que traz reflectida na cara a necessidade historica de acabar com o patronato e varrer o latifundio. Não devemos espichar muito o sentido social dos romances de Graciliano. Não ha duvida que S. Bernardo traz umas congitações inesqueciveis no assumpto. Póde ser mesmo que elle não tenha intenções. Dantes eu teimava na negativa das intenções em romance. Mas todo escritor ${ }^{205}$ hoje que não é revolucionario é homem morto. Aquelle homenzinho que está em Lobo de Estepe revelaria melhor a physionomia inceracteristica ${ }^{206}$ e cynica dos escriptores "puros" e dos escriptores "á margem". Elles passivamente, negam o processo historico que está transformando a humanidade. O escriptor puraramente literario (entende-se literatura no sentido burguez) é um esplorador como qualquer dos esploradores. Peior, muito peior. É mais nocivo que um Gustavo Barroso. Este pelo menos se desmascarou. Um coronelzão da litteratura ${ }^{207}$ latifundiaria. Tem sesmarias e sesmarias de pretensão e de mediocridade com o "primado espiritual" das medalhas cunhadas no ouro do Rothschild.

Graciliano é um escriptor revolucionario. Elle vai subindo a "escada". Tem ainda uma volupia muito literaria de espremer e jogar xadrez com os personagens. Mas ha no fundo o sentimento serissimo de conspirador de um homem que se mudou pro nosso lado, para o lado humano dos proletarios de todos os paizes.

\footnotetext{
${ }^{205}$ Variação de escriptor.

206 Erro tipográfico: "incaracterística"

${ }^{207}$ Variável. "Literatura" com um " $\mathrm{t}$ " era bem pouco frequente.
} 


\title{
RECORTE TEMPORAL FINAL: VÁRIOS ASSUNTOS (1936-1938)
}

Revista Academica, n. 19, p. 7, 06/1936 208

Propaganda

\begin{abstract}
Angustia - Em edição José Olimpio está para sair o terceiro romance de Graciliano Ramos.

Graciliano Ramos é romancista mais indicutivel com que conta o Brasil de hoje. O que se chama intensidade, ha nas suas obras. Intensidade é a pobreza de quase todos os nossos romancistas. Por isso, Graciliano Ramos ganha um destaque dificil de exagerar.
\end{abstract}

Uma coisa se tem assegurado: ANGUSTIA é o seu melhor livro.

A Proposito do Sr. Graciliano Ramos, "Collaborações" / Diário Carioca, 22/12/1936

Augusto Frederico Schmidt

O fundador deste jornal J. E. de Macedo Soares, que alia a um espirito de decisão e, direi mesmo, a uma natureza aggressiva, um fundo de generosidade inalteravel, tratou no seu ultimo artigo da situação de alguns presos politicos - em virtude dos acontecimentos de 27 de novembro - e que são, muito mais do que culpados da revolução communista, victimas de circumstancias, e de simples indicios, sem relação com os terriveis acontecimentos, que vieram despertar a nação e chamar a attenção do Brasil para sim mesmo.

Não conheço por exemplo os motivos que originaram a prisão que está durando ha quase um anno do sr. Graciliano Ramos, em Alagoas, mas o certo é, que me têm seguidamente esclarecido, pessoas merecedoras de todo o credito, tratar-se de um triste engano, infelizmente commum em epocas de necessaria repressão.

$* * *$

O sr. Graciliano Ramos é um dos nomes mais significativos das letras novas do Brasil. Romancista de altos meritos, não transformou absolutamente a sua arte em instrumento de acção politica, conservando-a pelo contrario num plano livre e puro. Segundo testemunhos de amigos communs, trata-se outrossim de uma natureza estranha á paixão partidaria, de um homem solitario, por excellencia, pouco dado a apostolados facciosos e conspirações, isto não por falta de energia, mas por feição propria, por temperamento.

Iniciado (sic) já em plena maturidade a sua atictividade de escriptor, é autor de tres romances cheios de altas qualidades. "Os Cahetés", "S. Bernardo" e "Angustia", com os quaes se firmou de maneira invulgar. São livros em que o problema humano importa muito mais do que o social. Em que ha conflictos de naturezae ${ }^{209}$, e não conflictos de carater politico, o que constitue por si um indicio de que a attenção do autor não se detem de preferencia sobre themas sociaes que o transformassem em propagandista de qualquer regime.

\footnotetext{
${ }^{208}$ Fonte: acervo de revistas da Fundação Casa de Rui Barbosa, Rio de Janeiro. Neste número da revista, na página 9, foi publicado um trecho de Angústia com o título "Marina”. Na Revista Academica de número 20 é anunciado o Prêmio Lima Barreto, para dezembro de 1936.

${ }^{209}$ Erro tipográfico
} 
(Isto não significa que o thema social não possa estar "tambem" compreendido no romance. Estou apenas caracterizando a personalidade do romancista de "Angustia").

$* * *$

Estou certo e é perfeitamente compreensivel, que o sr. Graciliano Ramos foi victima apenas de circumstancias occasionaes e de que só a ellas deve a sua já tão longa detenção. Estamos deante de um caso em que a injustiça está mais nos acontecimento do que nos homens. A brandura do governo do sr. Getulio Vargas é por demais notoria, para que não se torne ridicula a accusação de que o romancista tenho sido victima de uma perseguição, de uma injustiça intencional.

Conta nas suas admiraveis "Memorias do Districto Diamantino", o velho Antonio Felício dos Santos o caso do intendente José Antonio de Meirelles Freire, conhecido na epoca por "Cabeça de ferro", e que é como anedota, muito representativa da justiça colonial: "Tendo o intendente Meirelles ordenado o despejo de certo contrabandista, na minuta que entregou ao escrivão para passar o mandado, por engano escreveu o nome de um outra pessoa.

O escrivão passou o mandado mas na hora da execução, reclamou mostrando a equivocação que tinha havido. "Execute-se o mandado disse o intendente, e lavre-se outro contra o criminoso". Assim foram todos despejados..."

O sr. Graciliano Ramos deve ser, salvo melhor juizo, o "equivocado" do caso. Mas a justiça hoje mudou. E, se foi preso, por engano de pessoa, estou certo que as nossas dignas autoridades, não insistirão em tel-o apartado da sociedade, que elle tanto dignifica.

Dispondo de uma columna diaria em jornal, de larga circulação e actuação doutrinaria insuspeita não podia deixar de lembar o "caso" deste intellectual brasileiro em reclusão.

Estou certo de que não estou falando por mim, mas por todos os homens de letras pedir "attenção para Graciliano Ramos".

$$
* * *
$$

Já é tão amargo por si o pão do espirito...

Revista Academica, n. $^{\circ} 27,05 / 1937^{210}$

Oswald de Andrade

Penso que Angustia tem um defeito. E' pequeno demais. Confesso que tive uma decepção com o final. A riqueza de Graciliano, a sua profundidade, (sic) deviam nesse livro desembocar no social. E' uma obra-prima amputada. Ela revela no entanto que temos alguem grande como Charles Dickens.

\footnotetext{
${ }^{210}$ As notas e artigos sobre Angústia publicados na Revista Academica e, a seguir, transcritos, foram coletadas na Fundação Casa de Rui Barbosa, Rio de Janeiro.
} 
Um ser medíocre, pouco inteligente, vulgarmente inculto. Pensa medíocre, com pouco inteligência e a incultura mais chã. Mas Graciliano Ramos, numa equidade opulenta, mostra que com a mesma violência e a mesma insolubilidade vital, o operário inculto, o filósofo requintadíssimo e o amanuense pensam. Lido o romance admiravel, ninguem mais deseja ser operário ou caipira, pra não ter seus tamanhos pensamentos. Com a decisão impiedosa de não fazer do caso que nos conta um "caso", Angústia como que revaloriza o pensamento com os botões, pondo afinal numa prática.

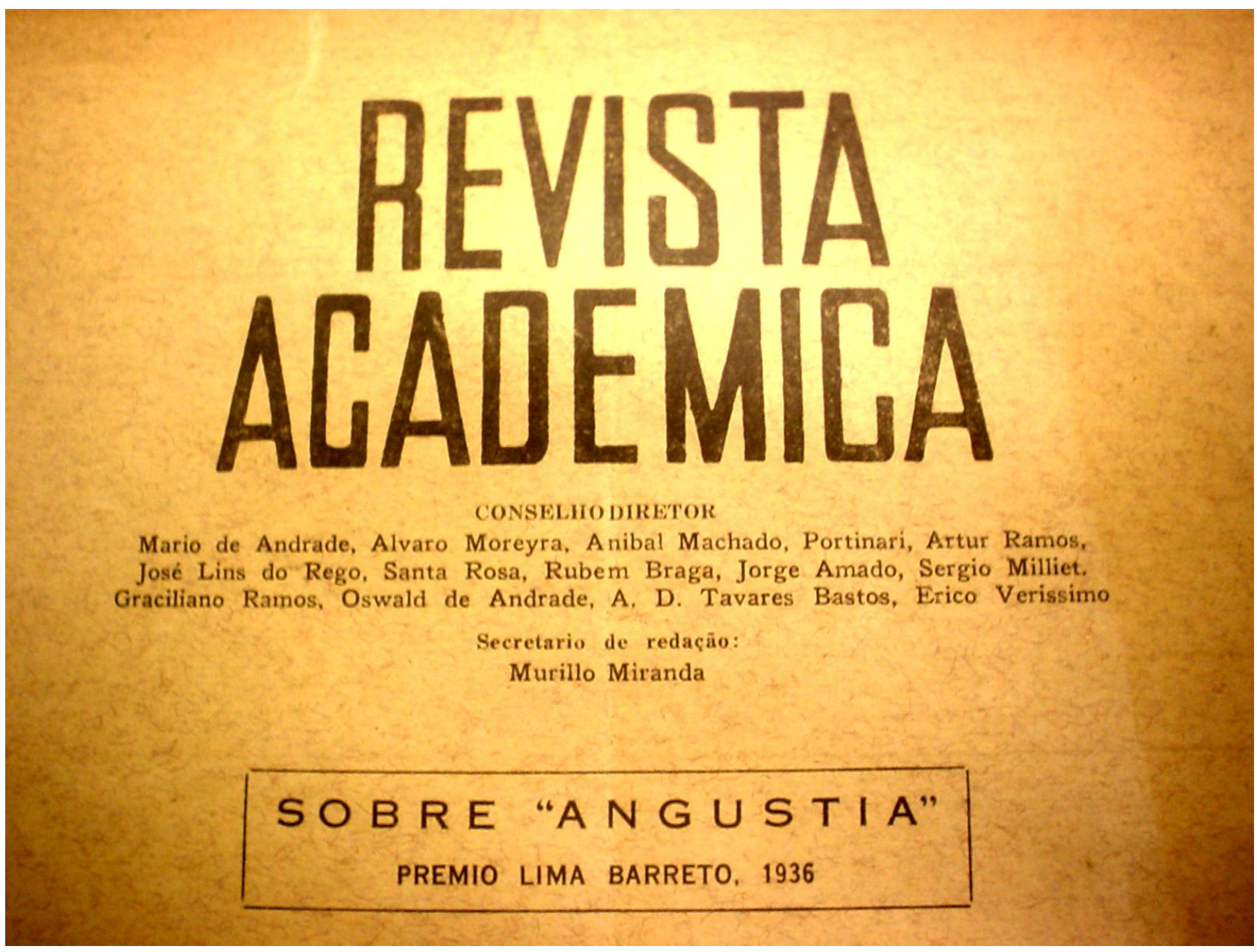

Graciliano e o Romance Brasileiro, Revista Academica, n. ${ }^{\circ}$ 27, 05/1937

Bezerra de Freitas

O que difficulta o surto de grandes romancistas, no Brasil - por mais estranho que pareça a affirmação - é a ausencia de material humano. A vida monotona das cidades e dos campos, a falta de grandes industrias ruraes ou urbanas, do typo da que se desenvolvem na Allemanha ou na America do Norte, a propria indole suave, cordial, quase lyrica do homem 
brasileiro, quaquer que seja o seu gráo de cultura, tudo isso tem influido poderosamente em nossas directrizes literarias. O romance foi sempre, nos paizes europeus, uma expressão animada, um reflexo poderoso da cultura collectiva, das affinidades emotivas das massas e das élites (sic), e o escriptor se contitue um fixador de instantes. Lutas religiosas, conflictos ethinicos, crises sociaes, choque de gerações, divergencias ideologicas, assim se annunciava, em ultima analyse, a literatura romantica gerada no velho mundo. Mas, onde estão estes themas eternos, para nós outros, habitantes desse mysterioso e impressionante deserto illuminado?

O romancista brasileiro vive em conflicto permanente com o ambiente physico e a atmosphera moral. A materia dos seus livros é formada dessa substancia commum aos povos que não possuem um longo passado de revoltas, de violencias e sacrificios. Por isso mesmo, Graciliano Ramos preferiu ser o interprete da sociedade do seu tempo, da civilização da sua época, das attitudes, dos costumes e das idéas do momento. Em Cahetés, em São Bernardo, em Angustia, o olhar do romancista se enche de raro brilho, devassando as regiões obscuras da nossa precaria animalidade. E' um prosador com o senso profundo da arte moderna, que baniu a descripção e desenvolveu o dialogo, o depoimento imprevisto, a conversação livre e rude. Por vezes, Graciliano Ramos nos dá a impressão de que deseja ser um romancista sem romance. E' talvez, o maior elogio que a critica literaria lhe poderá fazer. Sua sinceridade é uma profissão de fé.

Graciliano Ramos, Romancista de Costumes, Revista Academica, n. ${ }^{\circ}$ 27, 05/1937

Aydano do Couto Ferraz

Li o primeiro romance de Graciliano Ramos em 1934, logo que saiu do prélo, trazido do Rio para a Bahia por um literato que hoje me honro em ter como inimigo e que desdenha dos romancistas brasileiros porque leu Conrad e Strachey no original, nos tempos em que a nossa moeda valia alguma coisa e ele não possuia uma sinecura rendosa. Depois, Jorge Amado contou pelas colunas de Ariel as historia do boycott movido contra "Cahetés" pelo gordo editor Schmidt, que retardou ao maximo o seu aparecimento. E agora, que se tenciona prestar uma homenagem a este romancista a quem não conheço pessoalmente e de quem nunca recebi um volume, não é demais relembrar-se o crime de lesa-inteligencia que escondia esse boycott realizado por um livreiro que é tambem um intelectual, contra um escriptor honesto que ele compreendeu, mais cêdo ou mais tarde, viria a ter uma grande importancia nas letras nacionaes. Por isso, ainda hoje, sendo o autor de "S. Bernardo" visado desta maneira pelo boycott oficial (basta saber-se do acontecimento na Argentina com este livro, traduzido com o titulo de "Feudo Barbaro"), considero como solução fundamental para o prestigio da obra de Graciliano Ramos, a publicidade constante em torno dos seus livros. $\mathrm{O}$ escritor alagoano é um evadido do romance de costumes para o romance psicologico. E não é facilmente que o leitor mediano se acostumar com uma vertigem desta ordem na obra de um ficcionista como Graciliano Ramos, que crêa dramas psicologicos tão compactos de modo a não chegar a ser um escritor preferido do publico, nestas terras dos tropicos...

E que organização de construtor de romance é Graciliano Ramos! Construtor tão perfeito que fatiga pela uniformidade dos andaimes da sua obra.

Conheço mesmo alguns leitores seus que não foram além da primeira metade de "Angustia", dando-me a impressão de possuir esse grande romancista uma especie de meia travessa psicologica, como essa, outra do roteiro em que os homens do mar dividem as suas viagens. Não sei si fatigados com os detalhes de introspecção, ou mesmo, si deslocados dentro do realismo um tanto extremado, ou paradoxalmente inverossimil, das suas paginas. 
Porque a abulia de Luiz da Silva, essa então, não é capaz de repugnar a ninguem. E' um caso de disecação psicologica de um doente, e todo seu desenrolar, si bem que monotono nos perturba e nos prende.

Entretanto, eu acredito, não seria capaz de acontecer com os leitores de seu primeiro romance, "Cahetés". Ainda agora, no instante em que escrevo esta nota sobre Graciliano Ramos, relembro trechos do seu romance de Palmeira dos Indios, com a mesma facilidade com que relembro trechos de Eça ou Machado de Assis, gente que, por mais que fuja á citação, este romancista sempre me traz á memoria. João Valerio agredindo Luiza a beijos no cangóte. Adrião Teixeira, puxando da perna e dirigindo modorrentemente a sua firma comercial. O italiano Paschoal com "tanto sangue, tanto musculo, carcaça tão rigida, tudo empregado em dourar molduras e rabiscar monogramas". E assim até o fecho do livro, uma das coisas mais felizes achadas em romance brasileiro.

Não quero dizer com isso que "Cahetés" atinja a altura de "S. Bernardo" (em que um crítico sagaz já notava "a sua tendencia para o universal" ${ }^{211}$ ), nem mesmo a de "Angustia", onde Graciliano culmina como romancista, jogando com todas as suas notaveis qualidades. Mas, é que acho, frente ao publico, Graciliano Ramos não ganhou nada abandonando o romance de costumes inciado com "Cahetés". Porque o romance psicologico não é o romance do grande publico no Brasil. E um escritor como o autor de "Angustia", que pretende, ao menos agora, escrever para o povo, deve voltar, mesmo que temporariamente, ao romance de costumes, genero de ficção mais proprio para documentar os antagonismos sociaes. Quantos momentos de cultura da nossa formação de povo não gravaram os romances de Aluizio e de Lima Barretto?

E voltando á questão do publico, que corpo de leitores superior a Graciliano Ramos possuem Jorge Amado e José Lins do Rego, que si são na realidade escritores de maiores recursos que o primeiro, estão longe de possuir as suas qualidades de romancista! E' que os romances onde se joga com os costumes e a tradição, desprezando o lado individual dos temas psicologicos, são romances em que o povo se espêlha. A' espera, talvez, de encontrar nas suas paginas, sucitadas pelo autor, uma solução para os problemas em que se debate, certo de que com a sua participação ativa, eles serão resolvidos em seu beneficio, contra os inimigos seculares que ainda não conseguiu vencer.

\section{“Livros, Autores e Editores”, Estado de São Paulo, 07/07/1938 12}

(Autor não identificado)

\section{II}

As notas que a estas precederam ${ }^{213}$, bem como as presentes, tiveram, é bem de ver, um motivo ou excitação a provocar as reflexões que as inspiraram.

E' o caso que, ha dias, recebi de mãos amigas e gentis um livro, acompanhado da recommendação de lêl-o e aprecial-o. Li a brochura recente, com o interesse que a recommendação, vindo de quem vinha, impunha. Não vou, naturalmente, fazer o registro das

\footnotetext{
${ }^{211}$ Referência ao artigo de Agrippino Grieco, de 30/12/1934.

${ }^{212}$ Este e o último artigo encontram-se no Acervo Graciliano Ramos, Fortuna Crítica, do Instituto de Estudos Brasileiro da Universidade de São Paulo.

${ }^{213}$ Não foi encontrada a parte I do artigo. Assim, pela importância das colocações, o texto foi transcrito mesmo sem a referência do nome do colunista.
} 
impressões que a leitura me causou, pois sou inimigo de invadir seara alheia. Mas á proporção que percorria as paginas do "S. Bernardo" "214, do sr. Graciliano Ramos, iam-me brotando no bestunto umas considerações sobre o nosso mercado literario, os que escrevem, os que lêem e os que editam livros em nossa terra.

De taes considerações, as de caracter mais geral já aqui deixei consignadas na chronica anterior. Não são novidades; são, talvez, coisas que toda gente sabe. Mas convém sobre ellas, ás vezes, insistir.

Outras, que vou hoje aqui annotar, são menos geraes e prendem-se á leitura que as provocou.

"S. Bernardo" é mais uma obra que se filia ao cyclo nordestino que, ultimamente, tem contribuido com abundancia para avolumar a producção livreira nacional. Digo "cyclo", porque não me parece que propriamente se possa agrupar todas essas obras, desde a "Bagaceira" do sr. José Americo até o ultimo romance do sr. Lins do Rego, sob a denominação de "escola", que importa em phenomeno mais extenso e mais profundo. E mais significativo tambem.

Para não ferir melindres facilmente excitaveis, mencionarei um exemplo tomado ao passado. No tempo em que se fazia a propaganda da abolição da escravidão, foram numerosos os escriptores que para ella contribuiram, na imprensa e no livro, com os seus trabalhos. Ninguem pensaria, entretanto, em reunil-os sob o rotulo de "escola abolicionista". Mas os Sylvios Romeros do futuro poderão, com cabimento e propriedade, applicar-lhes a etiqueta de "cyclo da abolição". E' neste sentido que me parece adequada a expressão "cyclo nordestino".

Note-se desde logo que o Nordeste literario não coincide com o geographico. Tem lindes mais largos e vem mais ao Sul, até a Bahia em cujas letras recentes se notam algumas de suas manifestações.

A primeira observação que, ao ler o romance do sr. Graciliano Ramos, me ocorreu é a do ar de parentesco proximo, de intimidade aconchegada, que se verifica entre todos os todos os autores pertencentes ao "cyclo". Poder-se-ia quasi dizer que alli não ha originalidade individual. A originalidade é collcetiva, se assim é permittido dizer; pertence ao grupo tomado em bloco. E esta é, por certo, uma das mais accentuada caracteristicas do phenomeno literario a que assistimos. O cabedal de assumpto e de forma, de observações, inspirações, estilo, vocabulario, "trucs" e recursos, parece ser um fundo commum. Não sei se me exprimo bem ao dizer que se pensa numa especie de communismo intellectual que se teria implantado nessa provincia da Republica das Letras.

Esta é, porém, a impressão que reflue da observação daquelle aspectos de parentesco, daquelle "ar de familia", a que acima alludi e que congrega, em tocante solidariedade, todos os autores em apreço.

Esta fóra de questão a suspeita de que se trate de simples phenomeno de imitação. Não é isso. Não se poderia, sem imperdoavel injustiça, desconhecer o valor intellectual, o talento, a capacidade artistica, a espontaneidade, de muitos dos elementos que ornam o "cyclo nordestino". Não citarei nomes para não commetter injustiças por lapsos de memoria e para não excitar ciumes que seriam feios em tão unida familia.

A similitude, quasi identidade que se nota nos livros deste cyclo, provém da uniformidade do ambiente, esse meio tão carcteristico e singular do Nordeste, que se repete na successão seriada dos mesmos aspectos. A economia precária do assucar, a tragedia dolorosa das seccas, a estratificação das condições sociais girando circulatoriamente entre o "cabra" e o senhor de engenho, são os vertices do trinagulo que delimita o campo de onde o escriptor nordestino tira as suas inspirações. E tão profundamente se grava em sua impressionabilidade

${ }^{214} 2 .^{\text {a }}$ edição do romance. 
a angustia desse aspectos (sic) que não lhe é possivel quebrar na quasi totalidade dos casos, as barreiras que o encerram dentro desse triangulo para fugir áquelle campo.

Essas as raizes profundas da identidade essencial. Outras similitudes dahi derivam, naturalmente.

Esta familia literaria nordestina é numerosa. Numerosa e prolifica.

Porque a segunda observação que occorre a quem lê um dos livros deste cyclo é a abundancia com que os mesmos surgem, em successão ininterrupta, no mercado das edições nacionaes. A fertilidade, a capacidade de producção desses escriptores é, innegalvelmente, notavel, sobretudo se a compararmos com a mingua de livros merideonaes.

Dir-se-ia que o sol candente daquellas regiões não contribue apenas para augmentar a porcentagem de sacarose da canna, mas exerce influencia estimulante das mais marcadas sobre a imaginação e a productividade dos cerebros.

E' alli que se localisa a grande seára dos autores nacionaes. Sob o ponto de vista da producção literaria, em comparação com o Nordeste, as demais regiões do Brasil fazem triste figura.

Isto em relação á quantidade. Não me compete analysar a qualidade. Não sou, nem quero ser, critico literario. Deus me livre...

E aqui vem a ponto uma terceira observação que, espontaneamente, me surgiu ao espirito emquanto lia as paginas da brochura em cuja capa, como sempre, havia uma ilustração de Santa Rosa.

Tambem sob o aspecto da producção livreira, divide-se o Brasil em dois climas distinctos: ao Norte, os autores; ao Sul, os editores.

E' peculiar, mas é facto cuja explicação e analyse ahi deixo a tentar a argucia dos nossos sócio-psychologos.

Ao passo que é evidentemente ao Norte do paiz que cabe a primazia na producção de autores, na actualidade pelo menos, é no Sul que se concentram os editores. Todas as empresas editoras brasileiras estão situadas no Rio de Janeiro, São Paulo e Porto Alegre. Se o Norte escreve com maior abundancia, exclusivamente o Sul edita.

Deve haver uma razão para isso. Talvez mais de uma.

Não conheço as estatisticas das casas editoras, que as devem ter. Mas não parece que o motivo seja a accentuada predominancia do mercado consumidor nas regiões meridionaes. Porque no Norte tambem se lê, e não pouco. São numerosas por lá as livrarias que vendem as brochuras publicadas no Rio, São Paulo e Porto Alegre. E é de presumir que os autores encontrem nas suas terras a mais farta clientela. Outra será, pois, a razão. Procurem-na os estudiosos desses assumptos.

Quanto ao cyclo nordestino, o seu editor quasi exclusivo, monopolisador das respectivas produccões, é a Livraria José Olympio, localisada no Rio, mas paulista em essencia, pela sua direcção e pelos seus capitaes. O proprio estabelecimento de varejo desta empresa, alli á rua do Ouvidor, que pareceria normalmente indicado para ser ponto de encontro e reunião de paulistas em villegiatura por aqui, já foi, pela sua frequencia e "hantise" como dizem os francezes, qualificado de "consulado do nordeste". 
Escritor não é bicho do outro mundo, - Moços: Curityba, n. ${ }^{\circ}$ I, pag. 9, 12/1938

Herculano Torres Cruz

Em abril de 1936 cheguei ao Rio e foi quando conheci o autor de Cahetés e $S$. Bernardo. ${ }^{215}$ Já lhe conhecia os livros e tive então a agradavel surpresa de conhece-lo tambem. Naquele tempo eu estava, justamente, na fáse em que nós rapazes provincianos, imaginamos os escritores sêres irreais, de um mundo á parte - assim uma especie de figurões de Academias. Porisso achei esquisito quando o acaso não previsto pelo determinismo histórico me pôs em frente dos olhos o escritor alagoano em carne e osso. Foi numa pensão da rua Frei Caneca - na Pensão Neiva.

- $\quad$... aquele é Graciliano Ramos - o escritor, disseram-me.

- Aquele magro ali? - perguntei incrédulo e espantado. Aquele é meu colega de quarto, por sinal um companheirão, mas acho que você está enganado.

Mas não estava. Quem estava era eu. O sujeito magro, cabeçudo, de fisionomia bondosa, extremamente delicado, no quarto de quem "seu" Neiva me botára, era mesmo Graciliano Ramos, o escritor admiravel de São Bernardo. Fiquei olhando o bicho, espantado como já disse. Graciliano acabára de desbastar um cigarro, tirado-lhe um pouco de fumo, e punha-o na bôca, despreocupadamente, calmamente como qualquer mortal.

Então escritôres não eram só os que andavam de pince-nez, dedinho na testa, fardalhões? Havia escritôres diferentes, parecidos com a gente? E Graciliano Ramos da 1. ${ }^{\mathrm{a}}$ pagina do Boletim Ariel, das revistas Contemporanea e Academica, do Suplemento de "A Manhã", dos rodapés de Plinio Barreto, era um desses, um sujeito igual á gente, que trabalhava, lutava e sofria como a gente? Isso me impressionou tanto que passei o resto do dia como um gato a olhar o canario na gaiola. Não lhe perdi o menor gesto.

A' noite puxei uma prosinha. Até ali eu o havia chamado de você, porisso comecei desajeitado:

- O seu livro S. Bernardo é formidavel. (Não me ocorrera um sinônimo de formidavel. Formidavel é muito batido: fita formidavel, livro formidavel, garota formidavel, pernas formidaveis...) Fiquei chateado. Pigarreei p'ra disfarçar. O homem era escritor e eu a importunal-o com banalidade, com besteiras. Tentei recomeçar:

O senhor... S. Bernardo... Cahetés... Gostei muito...

Graciliano tirou-me do embaraço falando sobre o Paraná. Conhecia o jornal "O Dia" daqui, onde lera uma critica sobre os seus livros. Perguntou sobre o povo - tinha muito alemão? tinha muito nazista? Soubera que o integralismo aqui em Sta. Catarina tinha gente... Fui contando. Quando me apercebi já o chamava novamente de você. Ele mesmo me disse:

Vamos acabar com êsses senhores - nada de senhorias.

Falamos depois em Angustia, o seu proximo livro. Zé Olimpio já tinha os originais. Era romance realista. Mais realista que o rei dos seus romances de até então - S. Bernardo. Ele pretendia descrever, transmitir ao leitor a sensação que tinha experimentado por ocasião de uma operação que fizera. Sensação estranha e febril - ás vezes sentia-se dois, tinha "desdobramentos de personalidade". Mas não era só isso que êle queria fazer sentir. Queria contar como vivem Trajano Pereira de Aquino Cavalcante e Silva, seu filho reduzido a

\footnotetext{
215 A data intrigante desse suposto encontro, abril de 1936, levou-me a uma rápida investigação no primeiro volume de Memórias do Cárcere: sabemos que Graciliano foi preso em 03 de março de 1936, portanto tal encontro não seria possível senão no "Pavilhão dos Primários", Rio de Janeiro. De fato, houve a prisão de uma leva de paranaenses transferidos ao Rio. Dos vários indivíduos de que trata, Graciliano fala de um Herculano, muito provavelmente o autor deste artigo: "Herculano se distingue dos outros paranaenses, um estudante enfermiço, pequenino, amarelo como enxofre (...)” RAMOS, Graciliano. Memórias do Cárcere, vol. I, (Mestres da Literatura Contemporânea) / Rio de Janeiro; São Paulo: Record, (s.d.). (Cf. p. 359)
} 
Camilo Pereira da Silva, seu neto Luís da Silva, Marina, Julião Tavares \& Cia., D. ${ }^{\text {a }}$ Adélia, "seu" Ramalho, a parteira, Pimentel, Moisés, Dr. Golveia, a preta Vitoria, Lobishomem e as filhas, D. ${ }^{a}$ Rosalia, Antonia, Berta, a mulher da rua da lama, seu Ivo, o 16.384, Zé da Baía, etc. A gente quando termina de lêr o livro de Graciliano Ramos fica com vontade de cantar: "Oôôôô! vida marvada"...

E Graciliano conta compungido a história de toda aquela gente de Angustia. Fica-se sem saber quem sofre mais: - si o romancista, si aquele povaréu. Graciliano é um sujeito bom - tem dó dos outros e sofre por isso. Ele contou-me que tinha vontade de escrever um romance sobre os flagelados do Nordeste. Vira coisas pelos sertões dos Estados nordestinos de arrebentar o coração - miséria, sofrimento, fome, "vidas secas"... Massas humanas acuadas pela fome a assaltar fazendas, na marcha angustiosa em busca de pão. Vira coisas... Um dia contaria tudo. Agora, por último, via e vivia coisas negras. Não era mais observador estranho aos acontecimentos. Tomava parte neles - era massa, era número... vivia identificado, misturado com o povo, sentindo as sua dores, chorando as suas misérias, lutando - lutando sempre.

Um dia perguntei-lhe: - Graciliano, porque você não escreve alguma coisa sobre êsses dias que temos passado juntos. (Pergunta danada de ociosa). Temos visto tanta coisa: êsses vagabundos, degenerados em virtude do desamparo por parte do Estado, transformados em números de cabeça raspada, Cabo Costa, "camarão", Vitorio Canepa, Anspeçada Aguiar, o padre fazendo discurso, o jogo de futiból, as muquiranas, a fome e a sede...

- Tenho material para escrever o resto da vida. E escreverei disto tudo um bruto livro!

***

Já esperei dois anos, mais. Li nesse tempo o seu livro sobre os sub-homens do Nordeste - "Vidas Secas". Quero agora ler o grande livro sobre os sub-homens restantes. 


\section{BIBLIOGRAFIA}

Notas e Artigos sobre Caetés: Fonte: IEB - USP

AMADO, Jorge. (sem título), Revista Literatura, 05/ 12/ 1933

CAVALCANTI, Valdemar. O Romance "Cahetés”, Boletim de Ariel, 02/ 1933

GRIECO, Agrippino. "Corja", "Sinhá Dona" e "Cahetés" / "Vida Literária", O Jornal, 04/ 02/ 1934

LINS DO REGO, José. Cahetés, Revista Literatura, 05/ 02/ 1934

MENDES, Oscar. "Cronica Literária" / Cahetés - Graciliano Ramos - Schmidt, editor, Rio, 1933, Estado de Minas, 21/ 03/ 1934

\section{Notas e Artigos sobre São Bernardo: Fonte: IEB - USP}

SCHMIDT, Augusto Frederico. "Critica / Romances" - "S. Bernardo" - Graciliano Ramos - Ariel Editora Ltda. 1934. - Diário de Notícias - 16/12/1934.

JUREMA, Aderbal. "S. Bernardo" de Graciliano Ramos - Bolentim de Ariel Dezembro / 1934

GRIECO, Agrippino. “Critica” / Um Romance - Diário de Pernambuco - 30 / 12 / 1934

FRANCO SOBRINHO, Oliveira. "Romance e Novela" - O Dia - Curityba - 04 / 01 / 1935

BARRETO, Plínio. (Sem título), O Estado de São Paulo - 05 / 01 / 1935

XAVIER, Livio. "Livros Novos", Graciliano Ramos - "S. Bernardo" - Ariel Editora, Rio, 1934 - Diário de São Paulo - 06 / 01 / 1935

G. P. (pseudónimo) “S. Bernardo” - Graciliano Ramos - A Noite - 10 / 01 / 1935

MONTENEGRO, Olivio. A Margem do "S. Bernardo", Especial para o Diario de Pernambuco - 25 / 01 / 1935

LACERDA, Carlos. "S. Bernardo e o cabo da faca", Revista Academica - Janeiro de 1935

LEÃO, Mucio. "Registro Literário", Graciliano Ramos - São Bernardo (romance) Ariel - Rio - 1934, Jornal do Brasil - 02 / 02 / 1935

MENDES, Oscar. "Egoismo, S. Bernardo - Graciliano Ramos" - (Ariel, editora - Rio 1934), Folha de Minas - 17 / 01 / 1935

TARQUÍNIO DE SOUSA, Otávio. "Vida Literária”, Diário de Notícias - 17 / 02 / 1935 
AMADO, Jorge.“S. Bernardo e a Politica Litteraria”, Boletim de Ariel - Fevereiro de 1935

FAVERNARD, Antonio. "S. Bernardo" - Ariel Editora (Belém - Pará) / Folha de Minas - Belo Horizonte - 03 / 03 / 1935

MARTINS, Franz.“S. Bernardo”, O Povo (Fortaleza) - 06 / 03 / 1935

BARROS, Jayme de. “Chronica Literária”, para o Estado de Minas - 17 / 03 / 1935

COSTA, Dias da. "Literatura e Romance”, Diário de Notícias - 31 / 03 / 1935

AMADO, Jorge. "Livros nacionaes", Graciliano Ramos - S. Bernardo - Ariel, editora Rio - Movimento - maio de 1935

(Autor desconhecido) "Livros, Autores e Editores", O Estado de São Paulo - 07 / 07 / 1838

TORRES CRUZ, Herculano. "Escritor não é bicho do outro mundo", Moços / Curityba, n. ${ }^{\circ}$ I, pag. 9 - dezembro de 1938

\section{Bibliografia crítica sobre São Bernardo}

BAPTISTA, Abel Barros. "O Livro Agreste (I)” In: O Livro Agreste: Ensaio de Curso de Literatura Brasileira / Campinas, São Paulo: Editora da Unicamp, 2005.

BAPTISTA, Abel Barros. Na Torre da Igreja uma Coruja Piou: Autor ficcional e Ficção do Livro em "São Bernardo" In: Revista Colóquio Letras, n. o 129 / 130, Portugal, 1993. Fonte: http://colóquio.gulbenkian.pt/index.html

COSTA LIMA, Luiz. "A Reificação de Paulo Honório" In: Por Que Literatura? Petrópolis: Ed. Vozes, 1969.

GUARDIANO, Pascha Baldassari. Uma Leitura de São Bernardo: A Exortação Litótica / São Paulo-Franca: Série Teses e Monografias 1, 197(?), datilografada.

LAFETÁ, João Luiz. “O Mundo à Revelia” In: A Dimensão da Noite e Outros Ensaios / São Paulo: Duas Cidades; Ed. 34, 2004.

LINS, Osman. "Homenagem a Graciliano Ramos" In: In: BRAYNER, Sônia (org.) Graciliano Ramos, Coleção Fortuna Crítica / Rio de Janeiro: Civilização Brasileira, 1978.

PINTO, João Pereira. Diálogo entre a Literatura e a Filosofia em São Bernardo de Graciliano Ramos / Londrina: Ed. UEL, 1998. 
MOURÃO, Rui. A Estratégia Narrativa de S. Bernardo / Minas Gerais: Suplemento Literário (sem indicações do jornal), (s.d.). Fonte: Arquivo Graciliano Ramos. Série: Recortes / Fortuna Crítica de São Bernardo. IEB-USP.

WEBER, João Hernesto, "São Bernardo e os Dilemas da Tradição" In: FICHER, Luís Augusto. Caderno Porto e Vírgula, Graciliano Ramos, (org. Luís Augusto Ficher), Porto Alegre: Secretaria Municipal da Cultura, 1993.

ZILBERMAN, Regina. São Bernardo e os Processos de Comunicação. Porto Alegre: Editora Movimento/Instituto Estadual do Livro, 1975.

\section{Bibliografia sobre o autor e outras obras}

ABDALA JUNIOR, Benjamin. A Escrita Neo-realista: Análise Sócio-estilística dos romances de Carlos de Oliveira e Graciliano Ramos / São Paulo: Ática, 1981.

AMADO, Jorge. "Mestre Graça” In: RAMOS, Graciliano. Viagens / Rio de Janeiro; São Paulo: Ed. Record, 2002.

CANDIDO, Antonio. Ficção e Confissão: Ensaios sobre Graciliano Ramos / Rio de Janeiro: Ed. 34, 1992.

CRISTÓVÃO, Fernando Alves. Graciliano Ramos: Estrutura e Valores de Um Modo de Narrar / 2a . ed., Rio de Janeiro: Editora Brasília/Rio, 1977.

BASTOS, Hermenegildo José de M. Memórias do Cárcere, Literatura e Testemunho / Brasília: Editora Universidade de Brasília, 1998.

FACIOLI, Valentim A. "Dettera: Ilusão e Verdade - Sobre a (im)propriedade em alguns narradores de Graciliano Ramos", In: Revista do Instituto de Estudos Brasileiros n. ${ }^{\circ}$ 35, p. 43 à 68, São Paulo, 1993.

"Um Homem Bruto da Terra" In: GARBUGLIO, José Carlos; BOSI, Alfredo; e FACIOLI, Valentim (orgs) Graciliano Ramos. São Paulo: Editora Ática S.A., 1987.

IVO, Lêdo. Um estranho no ninho: a propósito do cinquentenário de Caetés de Graciliano Ramos In: Revista Colóquio Letras, n. ${ }^{\circ}$ 77. Portugal, p. 35, 1984. Fonte: http://coloquio.gulbenkian.pt/index.html

LIMA, Raul. "Sobre Graciliano Ramos" In: BRAYNER, Sônia (org.) Graciliano Ramos, Coleção Fortuna Crítica / Rio de Janeiro: Civilização Brasileira, 1978.

MALARD, Leticia. Ensaio de Literatura Brasileira: Ideologia e Realidade em Graciliano Ramos / Belo Horizonte: Ed. Itatiaia Ltda., 1976.

MARINHO, Maria Celina Novaes. A Imagem da Linguagem na Obra de Graciliano Ramos: uma análise da heterogeneidade discursiva nos romances Angústia e Vidas Secas / São Paulo: Humanitas / FFLCH/ USP, 2000. 
MIRANDA, Wander Melo. Graciliano Ramos / São Paulo: Publifolha, 2004.

MOREL PINTO, Rolando. Graciliano Ramos: Autor e Ator / Assis, S.P: Ed. da Faculdade de Filosofia, Ciências e Letras de Assis, 1962.

MOURÃO, Rui. Estruturas, Ensaio sôbre o Romance de Graciliano. Rio de Janeiro: Arquivo Editora e Distribuidora, 1971.

NOVAES COELHO, Nelly. "Solidão e Luta em Graciliano Ramos" In: Tempo, Solidão e Morte. Conselho Estadual de Cultura / Comissão de Literatura, Imprensa Oficial do Estado, São Paulo, 1964.

RAMOS, Graciliano. São Bernardo / posfácio "O mundo à revelia", João Luís Lafetá. I. Lafetá, João Luís, 1946 - II. Título. Rio de Janeiro: Ed. Rio, Record,1984.

2003.

Angústia / Rio de Janeiro: O Globo; São Paulo: Folha de São Paulo, Linhas Tortas / Rio de Janeiro: Record; São Paulo: Martins, 1975.

Infância / Rio de Janeiro; São Paulo: Ed. Record, 1995.

Memórias do Cárcere, prefácio: Nelson Wernek Sodré. (Mestres da Literatura Contemporânea) Rio de Janeiro/São Paulo: Editora Record/Altya, (s. d.).

RAMOS, Ricardo. "Lembrança de Graciliano" In: GARBUGLIO, José Carlos; BOSI, Alfredo; e FACIOLI, Valentim (orgs.) Graciliano Ramos. São Paulo: Editora Ática S.A., 1987.

Graciliano: Retrato Fragmentado. São Paulo: Siciliano, 1992.

VERDI, Eunaldo. Graciliano Ramos e a Crítica Literária / Florianópolis: Ed. da UFSC, 1989.

\section{Bibliografia Geral}

ANDRADE, Oswald. Serafim Ponte Grande / São Paulo: Globo: Secretaria do Estado de Cultura, 1990.

ARENDT, Hannah. A Condição Humana / Rio de Janeiro: Forense Universitária, 1999. Entre o Passado e Futuro, São Paulo: Perspectiva, 1972.

BAKHTIN, Mikhail (V. N. Volichínov) Marxismo e Filosofia da Linguagem: problemas fundamentais do Método Sociológico na Ciência da Linguagem / São Paulo: Ed. Hucitec, 1992. 
Problemas da Poética de Dostoiévsk / trad. Paulo Bezerra; Rio de Janeiro: Forense Universitária, 1997.

BARROS, Diana Luz Pessoa de. Teoria do Discurso: Fundamentos Semióticos / São Paulo: Humanitas / FFLCH / USP, 2001.

BARTHES, Roland - "Introdução à Análise Estrutural da Narrativa" In: Análise Estrutural da Narrativa - Seleção de Ensaios da revista Communications: Intr. Milton José Pinto; Rio de Janeiro: Ed. Vozes LTDA, 1973.

Crítica e Verdade / São Paulo: Ed. Perspectiva, 2003.

BAUDRILLARD, Jean. Senhas. Rio de Janeiro: DIFEL, 2001.

BENJAMIN, Walter. Magia e Técnica, Arte e Política: Ensaios sobre Literatura e História da Cultura / Obras Escolhidas V. 1 / São Paulo: Brasiliense, 1994.

BENVENISTE, Émile - Problemas de Lingüística II / trad. Eduardo Guimarães... , et al./ Campinas, São Paulo: Pontes, 1989.

BONOMI, Andrea - Fenomenologia e Estruturalismo. São Paulo: Ed. Perspectiva S.A., 2001.

BRITO, Mário da Silva. História do Modernismo Brasileiro: I antecedentes da Semana de Arte Moderna / Rio de Janeiro: Civilização Brasileira, 1997.

BUENO, Luís. Uma História do Romance de 30 / São Paulo: Edusp; Campinas: Ed. da Unicamp, 2006.

CANDIDO, Antonio. Formação da Literatura Brasileira (Momentos Decisivos) vol. 1. I

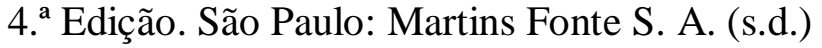

"A Revolução de 30 e a Cultura" In: A Educação pela Noite e Outros Ensaios / São Paulo: Ed. Ática S.A, 1989.

CHAVALIER, Jean. Dicionário de Símbolos: mitos, sonhos, costumes, gestos, formas, figuras, cores, números; Rio de janeiro: José Olímpio, 1999.

CIRLOT, Juan-Eduardo. Dicionário de Símbolos, S. Paulo: Moraes, 1984.

CUNHA, Euclides da. Os Sertões: Campanha de Canudos / Rio de Janeiro: F. Alves; Brasília: 1991.

DEL PRIORE, Mary. Esquecidos por Deus: monstros no mundo europeu e iberoamericano: uma história dos monstros do Velho e do Novo Mundo (séculos XVIXVIII) / São Paulo: Cia. das Letras, 2000.

FERNANDES, Florestan, "Mudanças Sociais no Brasil, Aspectos do desenvolvimento da sociedade brasileira" In: Corpo e Alma do Brasil, direção do Prof. Fernando Henrique Cardoso. São Paulo / Rio de Janeiro: Difel Difusão Editorial S.A., 1979. 
FIORIN, J. L. As Astúcias da Enunciação: as categorias de pessoa, espaço e tempo / São Paulo: Ática, 1996.

FREGE, Gottlob. Lógica e Filosofia da Linguagem / São Paulo: Cultrix/Edusp, 1978.

GENETTE, Gérard. "Fronteiras da Narrativa", In: Análise Estrutural da Narrativa Seleção de Ensaios da revista Communications: Intr. Milton José Pinto; Rio de Janeiro: Ed. Vozes Ltda, 1973.

GUIMARÃES, Hélio de Seixas. Os Leitores de Machado de Assis: o romance machadiano e o público de literatura no século 19 / São Paulo: Nankin Editorial / Editora da Universidade de São Paulo, 2004.

GREIMAS, A.J. "Elementos par uma Teoria a interpretação da Narrativa Mítica". In: Análise Estrutural da Narrativa - Seleção de Ensaios da revista Communications: Intr. Milton José Pinto; Rio de Janeiro: Ed. Vozes LTDA, 1973.

HALLEWELL, Laurence. O Livro no Brasil (sua história) / São Paulo: T. A. Queiroz, Editor / Editora da Universidade de São Paulo, 1985.

HANSEN, João Adolfo. Alegoria: construção e interpretação da metáfora / São Paulo: Atual, 1986.

A Sátira e o Engenho: Gregório de Matos e a Bahia do século XVII / São Paulo: Ateliê Editorial; Campinas: Editora da Unicamp, 2004.

HILTON, Stanley Eon. A Rebelião Vermelha / Rio de Janeiro: Record, 1986.

ISER, Wolfgang. The Implied Reader: Patterns of Communications in Prose Fiction from Bunyan to Beckett / The Johns Hopkins University Press: Baltimore and London, 1987.

O Ato de Leitura: Uma Teoria do Efeito Estético vol. 1 / trad. Johannes Kretschmer - São Paulo: Ed. 34, 1996.

O Ato de Leitura: uma teoria do efeito estético - Vol. 2 / trad. Johannes Kretschmer. São Paulo: Ed. 34, 1999.

JOYCE, James. Ulisses / trad. Antônio Houaiss. Rio de Janeiro: Civilização Brasileira, 2008.

JAUSS, Hans Robert. A História da Literatura como Provocação à Teoria Literária I Trad. Sérgio Tellaroli. São Paulo: Ed. Ática, 1994.

at all; (coordenação e tradução de Luiz Costa Lima). A Literatura e o Leitor, Rio de Janeiro: Paz e Terra, 1979.

JOUVE, Vincente. A Leitura / Trad. Brigitte Hervot. São Paulo: Editora da Unesp, 2002. 
LAFETÁ, João Luiz. 1930: A Crítica e o Modernismo / São Paulo: Duas Cidades; Ed. $34,2000$.

34, 2004.

A Dimensão da Noite e Outros Ensaios / São Paulo: Duas Cidades; Ed.

LINS, Álvaro. O Romance Brasileiro Contemporâneo / Rio de Janeiro: Edições de Ouro, 1968.

LUCÁKS, George. A Teoria do Romance: um ensaio histórico-filosófico sobre as forma da grande épica / São Paulo: Duas Cidades; Ed. 34, 2000.

MAINGUENEAU, Dominique. Análise de Textos de Comunicação / São Paulo: Cortez, 2004.

MANGUEL, Alberto. "O Participante Secreto" In: No Bosque do Espelho: ensaios sobre as palavras e o mundo / São Paulo: Cia. das Letras, 2000.

MEYER, Augusto. "O Homem Subterrâneo" In: Textos Críticos / João Alexandre Barbosa (org.), São Paulo: Perspectiva, 19(...).

MARX, Karl. A Origem do Capital: A Acumulação Primitiva / São Paulo: Global Editora, 1979.

NABUCO, Joaquim. O Abolicionismo / Rio de Janeiro: Nova Fronteira; São Paulo: Publifolha, 2000.

NAZZARI, Muriel. O Desaparecimento do Dote: Mulheres, Famílias e Mudança Social em São Paulo, Brasil, 1600-1900 / São Paulo: Cia das Letras, 2001.

NOVES COELHO, Nelly. Literatura e Linguagem (A obra literária e a expressão lingüística) / São Paulo: Edições Quíron, , 1986.

PEREIRA, Lúcia Miguel. Prosa de Ficção(de 1870 a 1920) / Rio de Janeiro: José Olímpio, 1957.

PHILLIPS, Adam - O Flerte / São Paulo: Companhia das Letras, 1998.

PONTIERI, Regina. "Roland Barthes e a escrita fragmentária" In: Língua e Literatura: Ensaios; Revista dos Departamentos de Letras da Faculdade de Filosofia, Letras e Ciência Humanas da Universidade de São Paulo / S. Paulo, ano XIV, v. 17, 1989.

POE, Edgar Allan. Poemas e Ensaios / São Paulo: Globo. 1999.

PRETI, Dino. Sociolingüística: Os Níveis de Fala, Um Estudo Sociolingüístico do Diálogo na Literatura Brasileira / São Paulo: Editora Nacional, 1974.

ROSENFELD, Anatol. "Literatura e Personagem”. In: A personagem de Ficção / São Paulo: Ed. Perspectiva S.A., 1998. 
ROSENTHAL, Erwin Theodor. O Universo Fragmentário / trad. Mário Fleicher. São Paulo: Ed. da Universidade de São Paulo, 1975.

SAFFIOTI, Heleieth Iara Bongiovani. A Mulher na Sociedade de Classes: Mito e Realidade; Petrópolis: Vozes, 1976.

SARTRE, Jean-Paul. O que é Literatura? São Paulo: Ed. Ática S.A., 1989.

STIERLE, Karlheinz. "Que Significa a Recepção dos Textos Ficcionais?” In: JAUSS, H. R. at all; (coordenação e tradução de Luiz Costa Lima). A Literatura e o Leitor, Rio de Janeiro: Paz e Terra, 1979.

TATIT, Luiz. Análise Semiótica Através das Letras, São Paulo: Ateliê Editorial, 2001.

TEIXEIRA, Ivan. "Policarpo Quaresma como Caricatura de Uma Idéia de Brasil" In: BARRETO, Lima. Triste Fim de Policarpo Quaresma / São Paulo: Ateliê Editorial, 2001.

TODOROV, Tzvetan. “As Categorias da Narrativa Literária” In: Análise Estrutural da Narrativa - Seleção de Ensaios da revista Communications: Intr. Milton José Pinto; Rio de Janeiro: Ed. Vozes LTDA, 1973.

WISNIK, José Miguel. O Coro dos Contrários: a música em torno da Semana de 22 I São Paulo: Duas Cidades, Secretaria da Cultura, Ciências e Tecnologia, 1977.

ZILBERMAN, Regina. Estética da Recepção e História da Literatura / São Paulo: Editora Ática, 1989. 